\title{
VAS ÉS EZÜST NANORÉSZECSKÉK KÖRNYEZETBARÁT ELŐÁLLÍTÁSA ÉS ALKALMAZÁSÁNAK VIZSGÁLATA
}

\section{DOKTORI ÉRTEKEZÉS}

\author{
RÓNAVÁRI ANDREA
}

TÉMAVEZETŐK:

DR. KÓNYA ZOLTÁN

DR. KIRICSI MÓNIKA

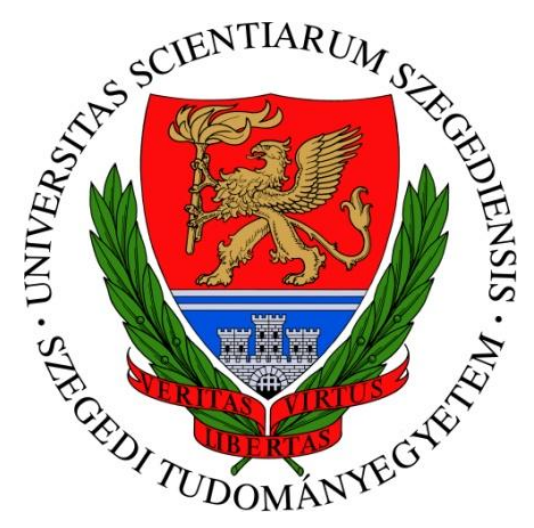

KÖRNYEZETTUDOMÁNYI DOKTORI ISKOLA SZEGEDI TUDOMÁNYEGYETEM TERMÉSZETTUDOMÁNYI ÉS INFORMATIKAI KAR ALKALMAZOTT ÉS KÖRNYEZETI KÉMIAI TANSZÉK 


\section{TARTALOMJEGYZÉK}

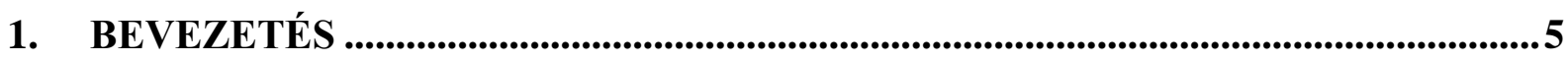

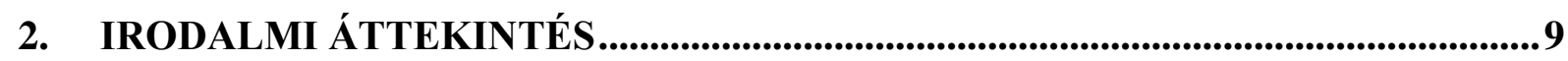

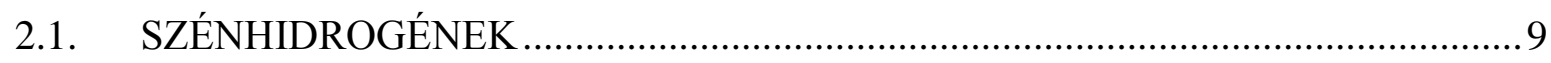

2.1.1. KLÓROZOTT ALIFÁS SZÉNHIDROGÉNEK ……………........................................

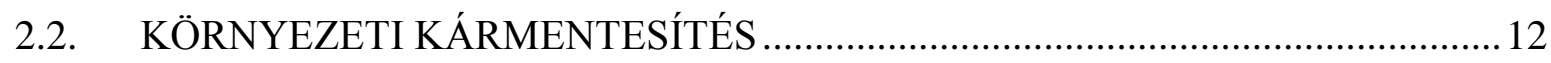

2.2.1. REMEDIÁCIÓS ELJÁRÁSOK ÉS CSOPORTOSÍTÁSI LEHETÖSÉGEI .................................. 12

2.3. KLÓROZOTT ALIFÁS SZÉNHIDROGÉNEK IN SITU REMEDIÁCIÓS

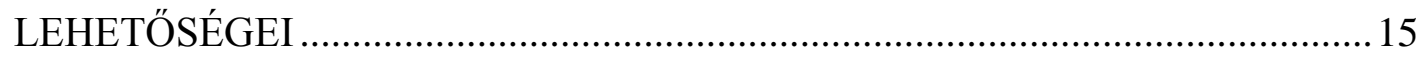

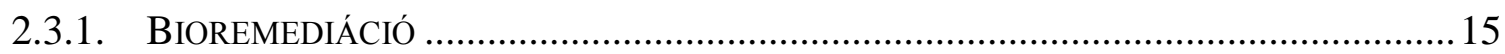

2.3.1.1. Biológiai remediáció klórozott szénhidrogének esetében ............................... 16

2.3.1.2. Klórozott alifás szénhidrogének biodegradációja.......................................... 18

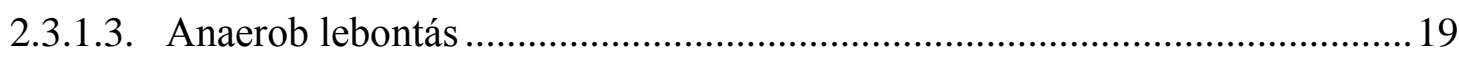

2.3.1.4. Biodegradációban résztvevő baktériumok kimutatása ....................................21

2.3.1.5. Kompetitív mikroorganizmusok a reduktív deklorináció során .......................23

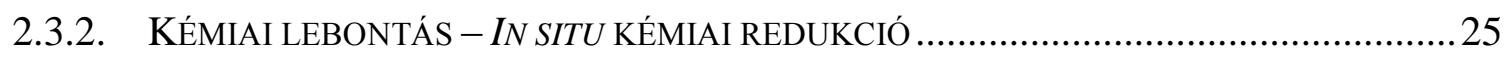

2.3.2.1. Nulla vegyértékủ vas nanorészecskék általános jellemzése ...........................25

2.3.2.2. Nulla vegyértékủ vas nanorészecskék szerepe a környezeti remediálásban . 26

2.3.2.2.1. A nulla vegyértékủ vas hatásának kémiai alapjai..................................28

2.3.2.2.2. Nulla vegyértékủ vas alkalmazása klórozott szénhidrogének

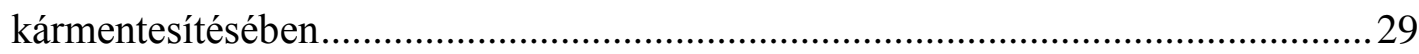

2.3.3. VAS NANORÉSZECSKÉK HATÁSA A TALAJBAN ÉLŐ BAKTÉRIUMOKRA ......................32

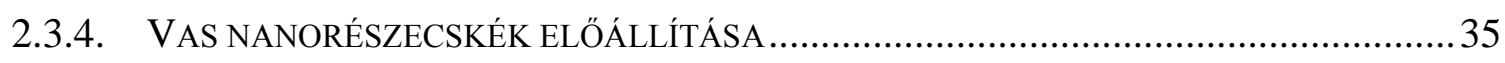

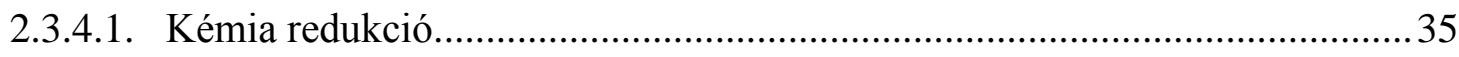

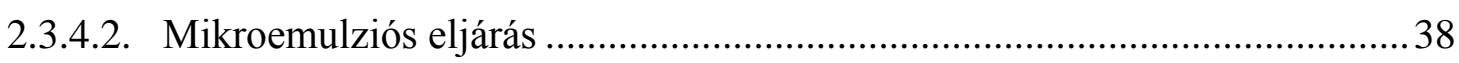

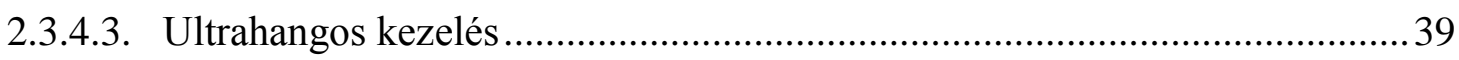

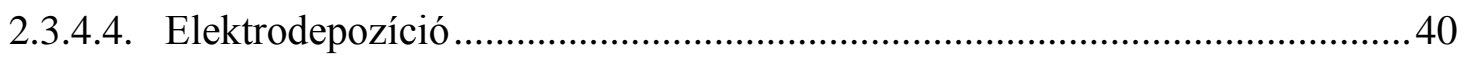

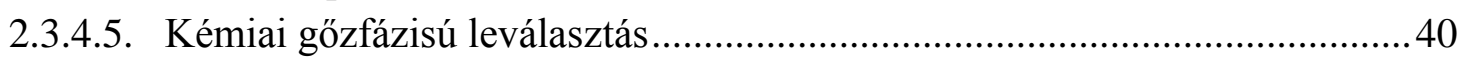

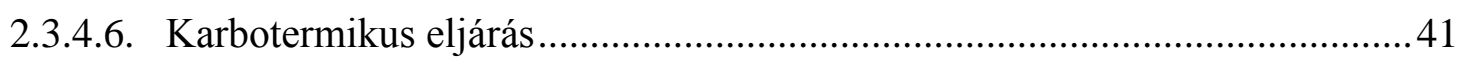

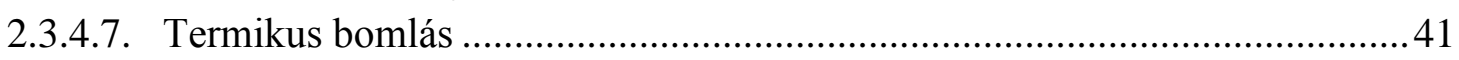

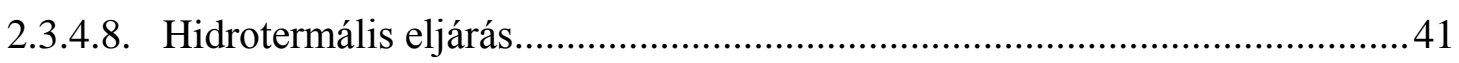

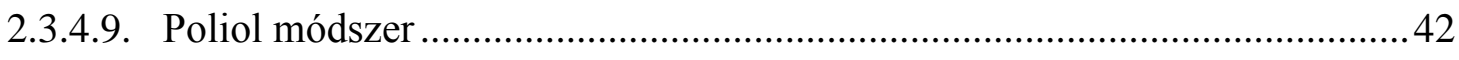

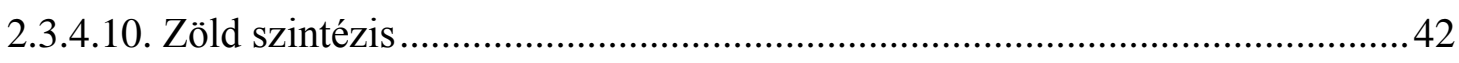

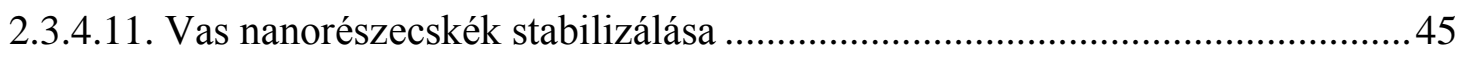

2.4. EZÜST NANORÉSZECSKÉK ELÖÁLLÍTÁSA ZÖLD SZINTÉZISSEL .............47

3. CÉLKITŰZÉS .........................................................................................50

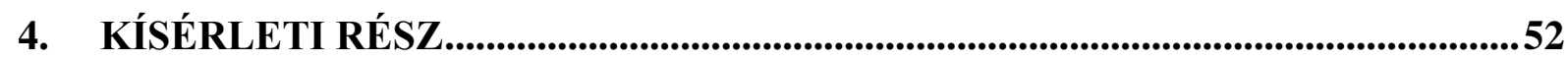

4.1. A KÍSÉRLETI MUNKA SORÁN FELHASZNÁLT ANYAGOK ……………......52

4.2. VAS ÉS EZÜST NANORÉSZECSKÉK ELÖÁLLÍTÁSA ......................................52

4.2.1. VAS NANORÉSZECSKÉK ELÖÁLLÍTÁSA FÉLIG-ZÖLD MÓDSZERREL ..........................52 
4.2.2. VAS NANORÉSZECSKÉK ELÖÁLLÍTÁSA ZÖLD MÓDSZERREL - NÖVÉNYI KIVONATOK 54

4.2.3. EZÜST NANORÉSZECSKÉK ELÖÁLLÍTÁSA ZÖLD MÓDSZERREL - NÖVÉNYI

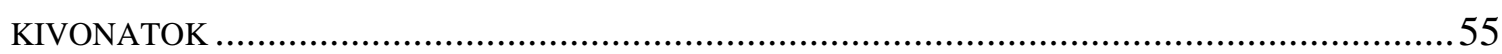

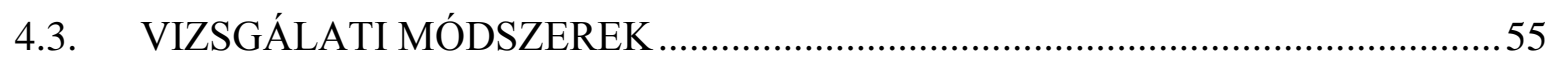

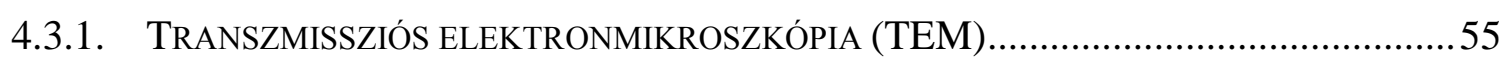

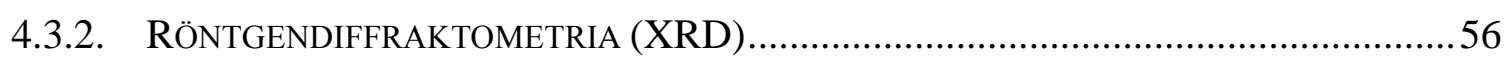

4.3.3. ENERGIADISZPERZÍV RÖNTGENSPEKTROSZKÓPIA (EDS) .......................................56

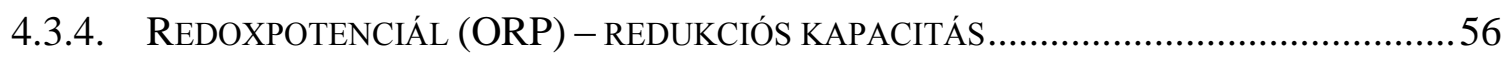

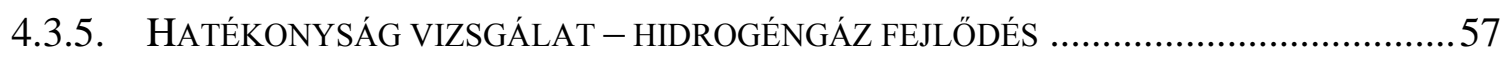

4.3.6. HATÉKONYSÁG VIZSGÁLAT - ILLÉKONY KLÓROZOTT SZÉNHIDROGÉNEK

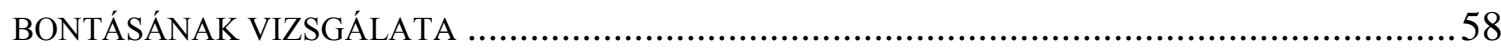

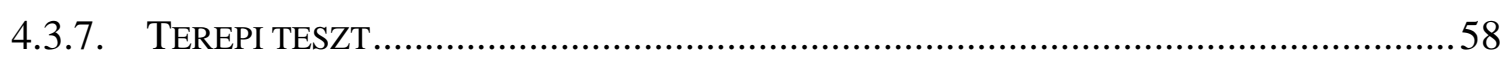

4.3.8. INDUKTÍV CSATOLÁSÚ PLAZMA-TÖMEGSPEKTROMETRIA (ICP-MS).......................59

4.3.9. ULTRAIBOLYA-LÁTHATÓ ABSZORPCIÓS SPEKTROMETRIA (UV-VIS) ....................59

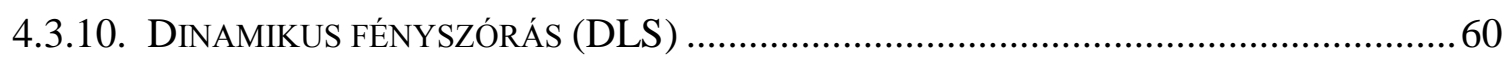

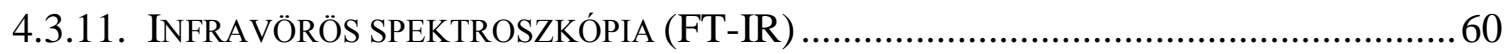

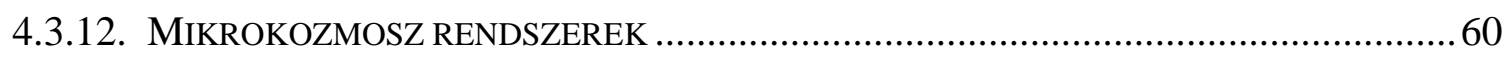

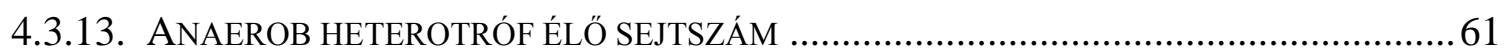

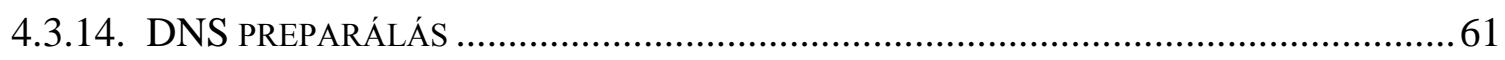

4.3.15. POLIMERÁZ LÁNCREAKCIÓ (PCR) ÉS DENATURÁLÓ GRADIENS

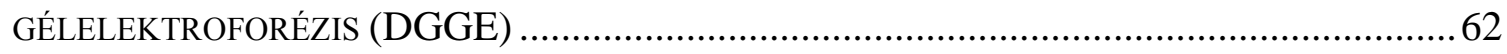

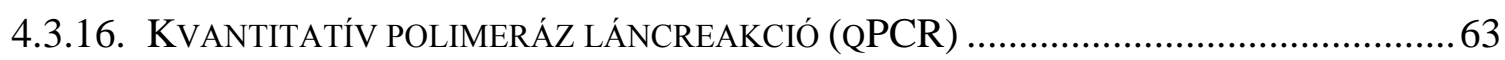

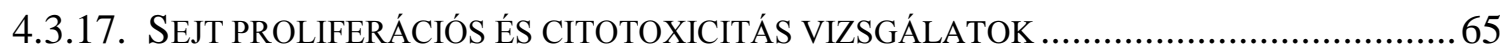

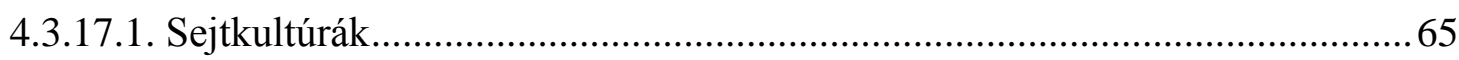

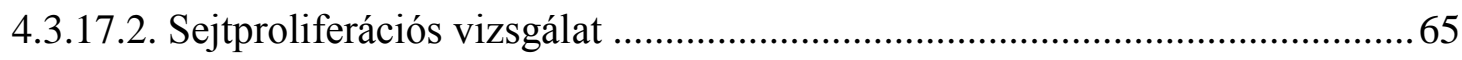

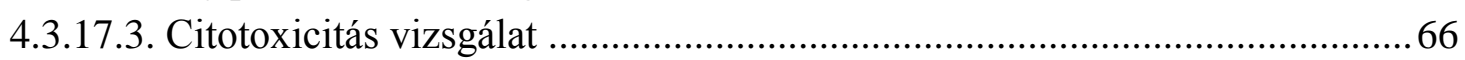

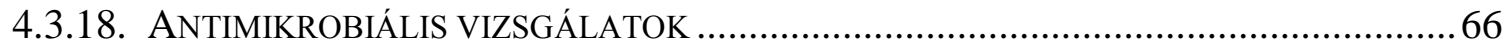

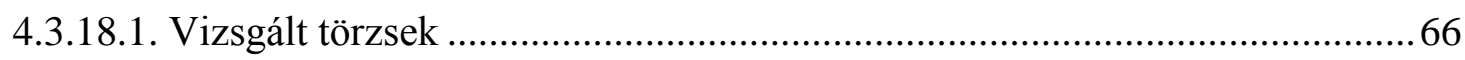

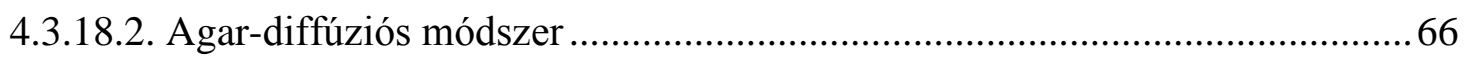

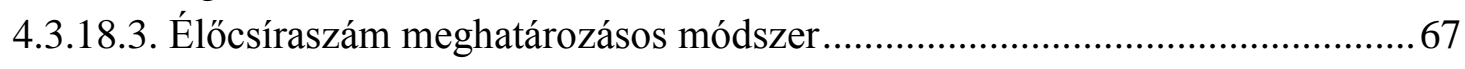

5. EREDMÉNYEK ÉS ÉRTÉKELÉSÜK .......................................................................68

5.1. NULLA VEGYÉRTÉKÜ VAS NANORÉSZECSKÉK KÖRNYEZETBARÁT ELÖÁLLÍTÁSA ÉS REMEDIÁCIÓBAN VALÓ ALKALMAZHATÓSÁGÁNAK

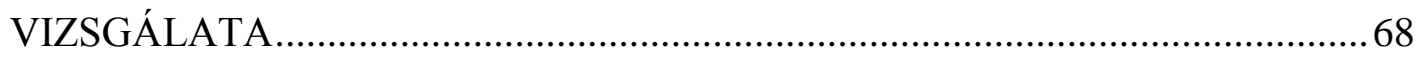

5.1.1. KÉMIAI REDUKCIÓVAL ELŐÁLLÍTOTT NULLA VEGYÉRTÉKÜ VAS NANORÉSZECSKÉK

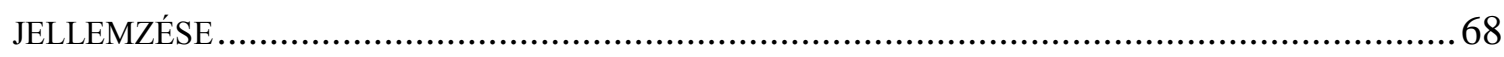

5.1.1.1. Transzmissziós elektronmikroszkópia - morfológia és méret ......................69

5.1.1.2. Röntgendiffraktometriás vizsgálatok - kristályszerkezet............................ 71

5.1.1.3. Redoxpotenciál mérések - redukciós kapacitás ....................................... 72

5.1.1.4. Hidrogéngáz fejlődés vizsgálat - hatékonyság......................................... 75 
5.1.1.5. Illékony klórozott szénhidrogének bontásának vizsgálata laboratóriumi

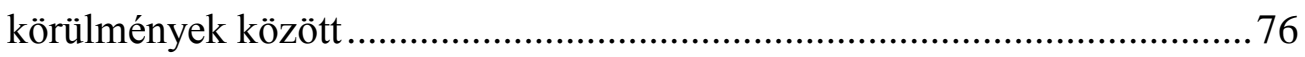

5.1.1.6. Vas nanorészecskék alakját befolyásoló védőmolekula adagolása ................. 80

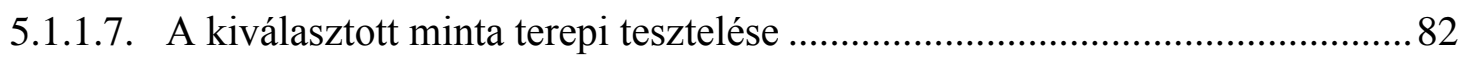

5.2. MIKROKOZMOSZ VIZSGÁLATOK: NULLA VEGYÉRTÉKÜ VAS

NANORÉSZECSKÉK HATÁSA A KLÓROZOTT ALIFÁS

SZÉNHIDROGÉNEK DEGRADÁCIÓJÁRA ÉS A DEKLORINÁCIÓBAN

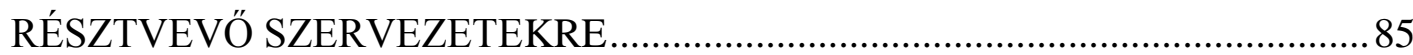

5.2.1. KÜLÖNBÖZŐ NULLA VEGYÉRTÉKÜ VAS NANORÉSZECSKÉK HATÁSA A MIKROBIÁLIS ÖSSZETÉTELRE 86

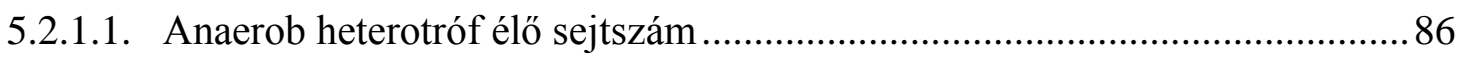

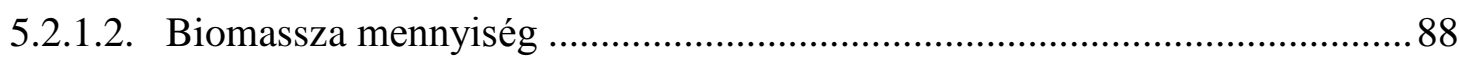

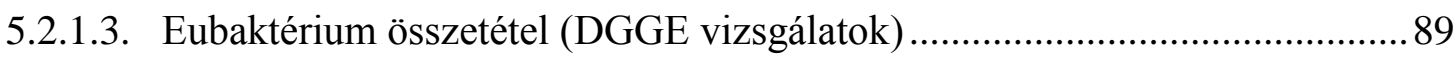

5.2.1.4. A biodegradációban részt vevő baktériumok relatív mennyiségének változása

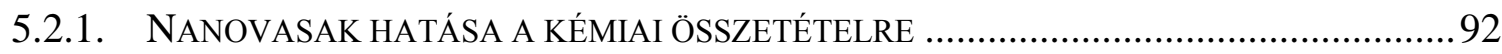

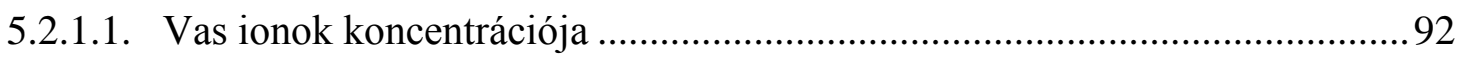

5.2.1.2. Reduktív deklorináció a mikrokozmosz rendszerekben a különböző nanovas adagolás mellett

5.3. NÖVÉNYI KIVONATOKKAL ELÖÁLLÍTOTT EZÜST NANORÉSZECSKÉK KÉMIAI ÉS BIOLÓGIAI AKTIVITÁSÁNAK ÖSSZEHASONLÍTÓ VIZSGÁLATA 96

5.3.1. A NÖVÉNYI KIVONATOKKAL ELÖÁLLÍTOTT EZÜST NANORÉSZECSKÉK JELLEMZÉSE 97

5.3.1.1. Transzmissziós elektronmikroszkópia - morfológia és méret 97

5.3.1.2. Röntgendiffraktometriás vizsgálatok - kristályszerkezet............................97

5.3.1.3. Dinamikus fényszórás - hidrodinamikai átmérő .......................................98

5.3.1.4. Ultraibolya-látható abszorpciós spektrometria - szerkezet.......................... 99

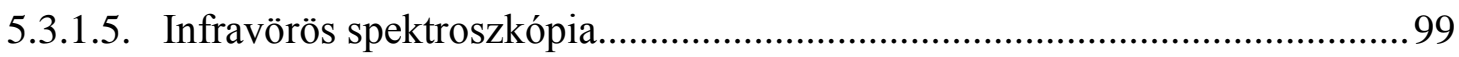

5.3.2. A NÖVÉNYI KIVONATOKKAL ELÖÁLLÍTOTT EZÜST NANORÉSZECSKÉK

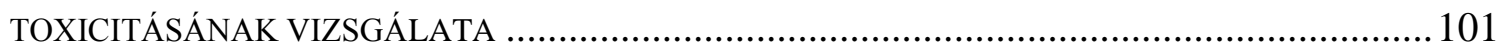

5.3.2.1. A növényi kivonatokkal előállított ezüst nanorészecskék toxicitásának

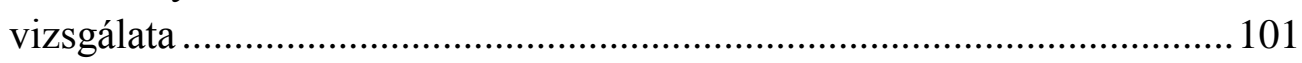

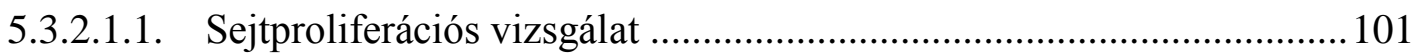

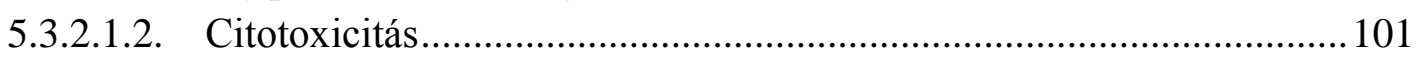

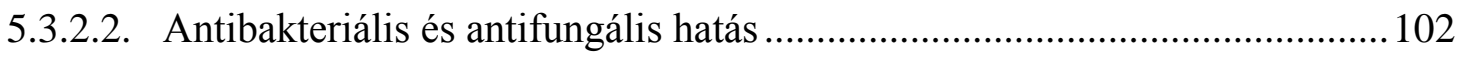

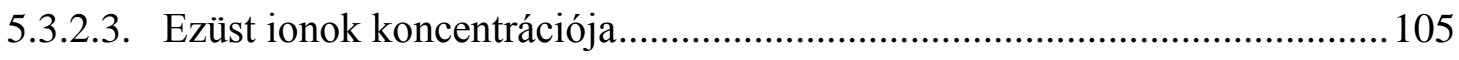

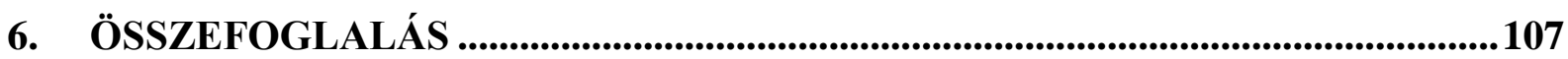

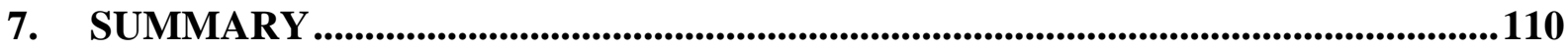

KÖSZÖNETNYILVÁNÍTÁS ...................................................................................................... 113

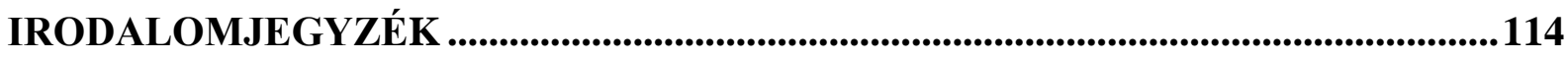




\section{BEVEZETÉS}

Társadalmunk egyre égetőbb problémája a talaj, a víz és a levegő óriási mértékű elszennyeződése. A növekvő népesség egyre fokozódó szükségleteinek kielégítő biztosítása nagymértékü környezetterhelést eredményez világszerte. A múlt század elejétől jelentősen megnövekedett ipari és mezőgazdasági tevékenység, az ásványi nyersanyagok meggondolatlan ütemü és mennyiségü kitermelése és felhasználása, az urbanizáció, a szennyezőanyagok utólagos felismerése és nem megfelelő kezelése mind hozzájárultak környezetünk jelenlegi szennyezettségi állapotához. A természetes (biogén vagy geokémiai) anyagok mellett a környezetünkbe kerülő számos antropogén eredetü, élő szervezetekre sokszor mérgező vegyület komoly kihívást jelent a környezet számára, mivel a természetes rendszerek nincsenek felkészülve ezeknek az anyagoknak a gyors lebontására.

A fenntartható fejlődés érdekében és az egészséges környezetben éléshez való jog alapján a fentiekből következően alapvető társadalmi célkitüzésként fogalmazódik meg a ma még utópikusan hangzó drasztikus szemléletváltás mellett a környezetterhelés csökkentése, valamint a kármentesítési technológiák fejlesztése és optimalizálása, amelyekkel a földtani közegek és felszín alatti vizek eredményesen kezelhetőek.

Az Egyesült Államokban és a fejlett nyugati országokban már a 70-es években felismerték a veszélyt, és felhívták a figyelmet a földtani közeg és a felszín alatti víz szennyezés felmérésének fontosságára, a szennyezett területek azonosítására és helyreállítására, a környezeti értékek megóvására, illetve ennek jogi szabályozására. Számos, a természetes környezetet ért káros hatás visszaszorításával, a szennyezett területek felmérésével és kezelésével foglalkozó környezetvédelmi határozatot és törvényt hagytak jóvá, valamint környezetvédelmi programokat (pl. az amerikai Superfund és a német Altlasten program) indítottak. Kezdetben csak a talajokat és a felszín alatti vizeket veszélyeztető környezetvédelmi problémák, források azonosításával foglalkoztak. Később, felismerve e területek kulcsfontosságú szerepét a mindennapi életünkben, hatékony, költségkímélő és környezetbarát kármentesítési eljárások kidolgozásával és azok fejlesztésével folytatták a munkát.

Magyarországon a 90-es évek elejéig sajnálatos módon semmilyen környezetvédelmi jogszabály nem korlátozta az ipari, mezőgazdasági és katonai fejlesztéseket, beruházásokat ${ }^{1}$.

A XX. század második felében a felgyorsult iparosodás, a mezőgazdaság kemizálása és gépiesítése miatt exponenciálisan megnőtt a különböző környezeti elemek, a talaj, a víz és a levegő szennyezése ${ }^{2}$. A 90-es évek elején már nem lehetett figyelmen kívül hagyni ezt a 
súlyos környezetvédelmi problémát, a kármentesítés iránt egyre fokozódó társadalmi és gazdasági igény jelentkezett. Így a fejlett országok tapasztalatait figyelembe véve, 1996-ban hazánkban elindították az Országos Környezeti Kármentesítési Programot $(\mathrm{OKKP})^{3}$, melynek célja a földtani közegben és a felszín alatti vizekben felhalmozódott és hátramaradt szennyeződések és azok minőségének és mennyiségének felderítése, a környezeti károk mérséklése, lehetőség szerinti felszámolása, továbbá az újabb szennyeződések kialakulásának megakadályozása. A felmérések alapján hazánkban a szennyezett területek száma megközelítőleg 30-40 ezerre tehető.

Magyarországon a lakossági vízhasználat 95\%-a felszín alatti vizekből származik, ezért különösen fontos ezeknek a vizeknek védelme és a talajvíz, illetve a talajba kerülö szennyeződések kezelése. A hazai környezetvédelmi gyakorlat egyik leggyakoribb kihívása a felszín alatti vizek és a földtani közeg szénhidrogén szennyezettségének felderítése és megszüntetése. Jelenleg a legnagyobb környezeti szennyezést a halogénezett szénhidrogének, köztük a klórozott rövid szénláncú vegyületek (CAH - Chlorinated Aliphatic Hydrocarbon) (pl. tetraklóretén $[\mathrm{PCE}]$, triklóretén $[\mathrm{TCE}]$, diklóretén [DCE], vinil-klorid [VC], szén-tetraklorid, kloroform, diklórmetán és klórmetán) okozzák ${ }^{4-7}$.

Ezeket a vegyületeket kedvező kémiai és fizikai tulajdonságaik miatt széleskörüen és nagy mennyiségben alkalmazták és alkalmazzák még ma is az iparban, a mezőgazdaságban és az egészségügyben (pl. oldószerként, csíraölőként vagy zsírtalanítóként). A melléktermékként képződött, valamint az alkalmazás után visszamaradt klórtartalmú szénhidrogének mind a mai napig komoly környezeti és egészségügyi problémát jelentenek, mivel perzisztensek, a víznél nagyobb sürüségủek, aerob körülmények között nem, vagy csak alig biodegradálhatóak, némelyek karcinogének, mutagének és toxikus hatásúak a környezetre és ránk nézve is.

Az elmúlt két évtized tényfeltáró felméréseinek, kutatási projektek eredményeinek és gyakorlati tapasztalatainak köszönhetően napjainkban már talajtisztítási technológiák százai állnak rendelkezésünkre, melyek döntően fizikai, kémiai, biológiai, termikus vagy szigeteléses eljárások.

A kármentesítés során - a fenntartható fejlődést szem előtt tartva - a bioremediációs folyamatoknak kell előtérbe kerülniük. Ezen eljárások a talajban folyó természetes szennyezőanyag-csökkentő folyamatokon alapulnak, kihasználva a talaj saját biológiai aktivitását. A bioremediáció előnye, hogy legtöbbször in situ kivitelezhető, nem igényel komolyabb infrastruktúrát, alacsonyabb költséggel jár, mint más, müszaki megoldásokat is igénylő remediációs módszerek. Ugyanakkor ennek az eljárásnak vannak korlátai is, például a köztes bomlástermékek esetleges felhalmozódása vagy a technológia időigényessége. 
A nanotechnológia és az egyre égetőbb környezetszennyezési problémák, valamint az egyre fontosabb környezetvédelmi szempontok találkozása hívta életre az ún. nanoremediációs eljárásokat. Ahogy az elnevezésből is látszik, ezek olyan kármentesítési folyamatok, amelyek során nanoméretü anyagot alkalmazunk. A nanotechnológia megjelenése a kármentesítési programokban - csakúgy, mint az élet egyéb területein hatalmas mértékben felgyorsította a technológiai fejlődést. Ezek a „kis” anyagok hatalmas problémákra nyújtanak és nyújthatnak megoldást. Számos publikációban számoltak be fém vagy fém-oxid nanorészecskék sikeres felhasználásáról a remediációs folyamatokban ${ }^{8}$. A környezeti gyakorlatban legtöbbször nulla vegyértékü vas nanorészecskéket alkalmaznak halogénezett szénhidrogénekkel szennyezett talajvizek in situ kármentesítésére? A felhasználásnak leggyakrabban az előállítási költségek szabhatnak gátat, így napjaink elsődleges feladata egy olyan gazdaságilag és ipari méretben kivitelezhető előállítási módszer kidolgozása, ami a nanoméretű anyagokat még inkább alkalmassá teszi a környezet védelmének szolgálatára.

Az alkalmazás további feltétele, hogy ismerjük a felhasznált nanoméretü vasrészecske teljes ökoszisztémára gyakorolt hatását, esetleges toxicitását, alkalmazhatóságának határait. Ehhez fontos felmérnünk, hogy a nulla vegyértékü vas nanorészecskék milyen hatással vannak a kármentesítés során kezelt közegben élő szervezetekre, hogyan és milyen mértékben változtatják meg a bakteriális közösség diverzitását, faji összetételét.

A fentiek alapján és a szennyezett természeti elemek (pl. földtani közeg, felszín alatti vizek) állapotának megismerésével és kármentesítésével foglalkozó tudományos fórumok, és lezárt, sikeres projektek sora bizonyítja, hogy igény van az innovatív, környezeti, gazdasági és társadalmi szempontból egyaránt előnyös technológiákra. A kockázatmenedzsment fejlődésével és a jövőbeni használatokból eredő hasznok figyelembevételével az optimálisan kombinált biológiai és a nanoremediációs eljárások versenyképes alternatívát jelenthetnek.

Doktori munkám során különböző reaktivitású és morfológiájú vas nanorészecskéket állítottunk elő hagyományos és zöld szintézissel. A részecskék szerkezetét, morfológiáját és reaktivitását részletesen jellemeztük, végül azt teszteltük, hogyan befolyásolják ezek a tulajdonságok a nanorészecskék valós környezeti minták mikrobiális összetételére és diverzitására gyakorolt hatását. Megállapítottuk, hogy egy hosszabb távú kármentesítési beavatkozás során milyen tulajdonságú vas nanorészecske alkalmazása javasolt klórozott alifás szénhidrogének sikeres lebontására.

A különböző módon előállított vas nanorészecskéknél megfigyelt eltérő kémiai jellemzők és a nanorészecskék biológiai rendszerekre gyakorolt eltérő hatásának pontosabb 
értelmezéséhez szükségesnek gondoltuk megfigyeléseink szélesebb körü kiterjesztését, melyhez egy jól ismert, az irodalomban konkrét referenciaértékekkel, meghatározott paraméterekkel rendelkező standard anyag, az ezüst nanorészecskék tanulmányozását választottuk. Az ezüst nanorészecskék jól definiált jellemzői lehetővé tették az általunk zöld szintézissel, növényi kivonatok segítségével elöállított ezüst nanorészecskék teljes körü kémiai és biológiai összehasonlító elemzését, különös tekintettel a redukálószerek esetleges befolyásoló szerepére. 


\section{IRODALMI ÁTTEKINTÉS}

\subsection{Szénhidrogének}

Az elmúlt évtizedekben az ipar és mezőgazdaság intenzív fejlődése, valamint a fejlett gazdasággal rendelkező országokban kialakult meggondolatlan fogyasztói magatartás következtében a környezetünkbe kerülő káros, természetidegen anyagok koncentrációja jelentős mértékben megemelkedett, számos környezetvédelmi problémát okozva. Ezáltal, a környezet védelmének fontossága napjaink egyik legaktuálisabb és egyben legaggasztóbb problémájává vált ${ }^{10}$.

Hazánkban, akárcsak az egész világon, a környezeti (talaj- és talajvíz) szennyezések nagy részét a földtani közegbe, illetve felszín alatti vizekbe jutó antropogén eredetű kőolajok és kőolajtermékek okozzák ${ }^{4,11}$. Szénhidrogén összetételét tekintve a kőolaj különböző szerkezetü és molekulatömegü normál paraffinok, izoparaffinok, cikloparaffinok és poliaromás szénhidrogének elegye. A kiterjedt ipari, mezőgazdasági és lakossági felhasználás miatt szinte mindenütt számíthatunk kőolaj eredetű szennyezésre, továbbá figyelembe kell vennünk a kőolaj kitermelése és feldolgozása során keletkező, valamint a helytelen tárolásból, szállításból, illetve egyéb ipari balesetekből származó lehetséges szennyezőforrásokat is 4 .

Széles körü felhasználásukkal összefüggésben környezetkárosító hatásuk is meglehetősen nagy ${ }^{12}$. A káros hatás függ a környezetbe kikerült szennyezőanyag koncentrációjától, eloszlásától, anyagi minőségétől, az expozíciós időtől, a környezeti feltételektől (pl. éghajlati, időjárási tényezők - csapadék mennyisége, domborzat - talaj elhelyezkedése, talajvíz mélysége), a közegben előforduló más anyagok jelenlététől, illetve az azokkal és az élő szervezetekkel (érintkezés, bejutás, esetleges lebontás) történő kölcsönhatástól ${ }^{13}$.

\subsubsection{Klórozott alifás szénhidrogének}

Számos, nagy mennyiségben előállított és kedvező fizikai-kémiai tulajdonsága (pl. nagyfokú ellenálló képesség és stabilitás, specifikus hatás) miatt alkalmazott vegyszerröl bizonyosodott be, hogy felhalmozódva a környezetben, közvetve vagy közvetlenül veszélyezteti az embert és a környezetet ${ }^{14}$.

Sajnálatos módon sok vegyszer esetében a megfelelö hatástanulmány (a termékek természeti környezetre, élővilágra gyakorolt hatásának felmérése) elkészítésére csak jóval azután került sor, amikor az alkalmazási területen már jelentős egészségügyi, környezeti 
problémák jelentkeztek és a beavatkozás elkerülhetetlen volt. Ilyenek a halogéntartalmú szerves vegyületek is, melyek között kiemelkedő helyet foglalnak el a főként oldószerként, zsírtalanító szerként, vagy extraháló szerként alkalmazott klórozott szénhidrogének ${ }^{15}$.

A klórozott rövid szénláncú vegyületek (pl. tetraklóretén, triklóretén, diklóretén, vinil-klorid, szén-tetraklorid, kloroform, diklórmetán és klórmetán) a talaj és a talajvíz rendszerek leggyakoribb, és különösen káros szennyezői közé tartoznak ${ }^{16}$. Az Országos Környezeti Kármentesítési Program felmérése szerint, csak hazánkban több ezer helyen található ilyen jellegü szennyezés ${ }^{3,11}$. A dolgozatban vizsgált legfontosabb klórtartalmú alifás vegyületeket a 2.1. táblázatban mutatom $b^{17}$.

\section{1. táblázat. Klórozott alifás etilén származékok}

\begin{tabular}{|c|c|c|c|}
\hline Név & Összegképlet & Jellemzők & Felhasználás \\
\hline vinil-klorid & $\mathrm{C}_{2} \mathrm{H}_{3} \mathrm{Cl}$ & $\begin{array}{l}\text { színtelen, szagtalan, } \\
\text { gyúlékony, édeskés szagú, } \\
\text { narkotikus hatású }\end{array}$ & $\begin{array}{l}\text { polimerek (PVC) előállítása, } \\
\text { hűtőfolyadék, oldószer }\end{array}$ \\
\hline 1,1-diklóretilén & $\mathrm{C}_{2} \mathrm{H}_{2} \mathrm{Cl}_{2}$ & színtelen, jellegzetes szagú & komonomerek \\
\hline 1,2-diklóretilén & $\mathrm{C}_{2} \mathrm{H}_{2} \mathrm{Cl}_{2}$ & $\begin{array}{c}\text { színtelen, nagyon gyúlékony, } \\
\text { jellegzetes szag, cisz-és transz } \\
\text { izomer }\end{array}$ & komonomerek \\
\hline triklóretilén & $\mathrm{C}_{2} \mathrm{HCl}_{3}$ & $\begin{array}{l}\text { színtelen, jellegzetes szag, nem } \\
\text { gyúlékony }\end{array}$ & $\begin{array}{l}\text { fémek felületi kezelése, } \\
\text { zsírtalanítószer, oldószer }\end{array}$ \\
\hline tetraklóretilén & $\mathrm{C}_{2} \mathrm{Cl}_{4}$ & színtelen, nem gyúlékony & $\begin{array}{c}\text { száraz vegytisztítás, } \\
\text { féregirtószer }\end{array}$ \\
\hline
\end{tabular}

Ezen vegyületek közös jellemzője, hogy stabilak, nehezen bomlanak, perzisztensek, anoxikus felszín alatti környezetben könnyen akkumulálódnak, tehát nehezen hozzáférhetőek. Vízzel kétfázisú rendszert alkotnak és a vizes fázis alatt helyezkednek el ún. DNAPL szennyezést okozva (Dense Non-Aqueous Phase Liquid: víznél nagyobb sürüségü, vízzel nem elegyedő folyadék). A talajvíz szintje alá is leszivárognak a talajban, így nem csak a talajvizet, de a mélyebb rétegekben elhelyezkedő vizeket is veszélyeztetik. A víz alatti rétegből folyamatosan szennyezőanyagot bocsáthatnak a vízbe - ami a talajvíz áramlásával messzire eljuthat, ivóvizeinket veszélyeztetve - így a kármentesítés során nehézséget okoz már az elhelyezkedésük megállapítása is, a források pontos azonosítása és lehatárolása mellett ${ }^{18}$.

A klórozott vegyületek ipari felhasználhatóságát a bennük lévő szén-klór kötés erőssége és az ebből adódó stabilitása határozza meg. Ugyanakkor a melléktermékként képződött és az alkalmazás után feleslegessé vált klórtartalmú vegyületek nagyon lassan 
bomlanak le, így potenciális környezetszennyezőként kell kezelnünk őket. A nem megfelelő kezelés és elhelyezés eredményeként a természetes felszíni és talajvizekbe, valamint a talajba és a levegőbe jutnak, lokális, regionális és globális problémákat okozva.

Bekerülve a talaj- és rétegvízbe, transzportjuk jelentős, így környezetkárosító hatásaik mellett figyelembe kell vennünk a humán egészségügyi hatásukat is. Az általuk okozott tüneteket és szervi elváltozásokat a 2.2. táblázat tartalmazza ${ }^{19}$. Gőzeiket belélegezve vagy börön, illetve szájon keresztül is bejuthatnak szervezetünkbe, ahol felhalmozódhatnak a zsírszövetben, vagy károsíthatják a központi idegrendszert, a májat vagy a vesét. Mivel lassan ürülnek és hosszú a féléletidejük, felhalmozódásuk rosszindulatú daganatok kialakulásához vezethet. $^{20}$. Minden alifás klórozott etilén toxikus, a vinil-klorid bizonyítottan humán karcinogén. Problémát okoz továbbá, hogy a részleges lebontásuk során keletkező köztitermékek gyakran toxikusabbak, mint a kiindulási anyagok ${ }^{21}$.

\section{2. táblázat. Szénhidrogének által okozott tünetek és elváltozások}

\begin{tabular}{ll}
\hline Érintett szervek & Tünetek \\
\hline Légzőszervek & $\begin{array}{l}\text { Nehézlégzés, cianózis, vérköpés, tüdőödéma, } \\
\text { tüdőgyulladás } \\
\text { Depresszió, zavartság, egyensúlyvesztés, } \\
\text { hányinger, hányás, fáradtság, kimerültség, } \\
\text { alvászavar, tudatvesztés, érzö- és motoros idegek } \\
\text { károsodása (paralizis), Parkinson tünetek }\end{array}$ \\
Gyomor és bélrendszer & Hányinger, hányás, hasmenés, hasfájdalom \\
Máj & Májenzimértékek emelkedése, gyulladás, fibrózis \\
\hline Vese & Akut tubuláris nekrózis, fehérjevizelés, vérvizelés \\
Vér és vérképző szervek & $\begin{array}{l}\text { Véralvadászavar, hemolítikus anémia, csontvelö } \\
\text { károsodás, akut leukémia }\end{array}$ \\
Bőr & Kiütések, eritémák, allergiás elváltozások \\
\hline
\end{tabular}

A fentieket figyelembe véve kijelenthetjük, hogy napjainkban a hazai környezetvédelmi gyakorlat egyik legfontosabb kihívása a felszín alatti vizek és a földtani közeg klórozott alifás szénhidrogén szennyezettségének felderítése és megszüntetése. 


\subsection{Környezeti kármentesítés}

Magyarországon a környezetszennyezések okozta károk csökkentése, megszüntetése és a környezet védelme csak az utóbbi évtizedekben került előtérbe. Napjainkra elfogadottá vált az a tény, hogy a termelés során szinte minden esetben számolni kell a különböző szennyezések környezetbe kerülésével, így minden potenciálisan veszélyes tevékenység megkezdése előtt részletes hatástanulmányt kell készíteni. Ez a környezetvédelmi elöírások szigorítását és a betartásukhoz szükséges technológiák fejlödését is eredményezte. Ezenfelül, számos környezetvédelmi határozatot és programot hoztak létre, melyek a természetes környezetet ért káros hatások visszaszorításával, a szennyezett területek felmérésével és kezelésével foglalkoznak ${ }^{3}$.

A környezetszennyezés okozta károk csökkentésének legegyszerübb módja a megelőzés, a szennyezők emissziójának megakadályozása lenne. Sajnos ez sok esetben nem oldható meg, mivel ezek a vegyületek már a környezetbe kerültek korábbi mezőgazdasági vagy ipari tevékenység során. Ezért legfontosabb szempontként azt kell szem elött tartani, hogy a technológiai fejlődés olyan irányba mutasson, amely a lehető legkisebb környezeti szennyezéssel jár (BAT - Best Available Techniques) ${ }^{22}$.

A múlt évszázadban nem tulajdonítottak nagy jelentőséget ezeknek az irányelveknek, így az alkalmazott technológiák jelentős környezeti károkat okoztak ${ }^{11}$. Annak ellenére, hogy a jelenlegi jogszabályozási háttérnek köszönhetően már nem lehetséges nagymértékü környezetvédelmi szennyezés kockázatával járó gazdasági tevékenységbe kezdeni, a jórészt megszünt egykori környezetszennyező tevékenységek által hátrahagyott szennyeződések felmérése és kármentesítése még mindig napjaink egyik legfontosabb feladata. Az ilyen „örökölt” szennyeződések legveszélyesebb jellemzői, hogy rejtve vannak, nehezen hozzáférhetőek, illetve a talajban és a talajvízben hosszútávon toxikus hatásúak. Hazánkban az ipari fejlődést követően számos olyan klórozott alifás szénhidrogénnel szennyezett terület maradt hátra ${ }^{11}$, amelyek további hasznosítása feltételezi a terület szennyezettségének megszüntetését, kármentesítését.

\subsubsection{Remediációs eljárások és csoportosítási lehetőségei}

A remediáció (a latin remedium - gyógyszer, gyógyítás szóból) a szennyezett környezeti elemek és/vagy fázisok (a talaj, a felszíni és felszín alatti vizek stb.) környezeti kockázatának elfogadható mértéküre csökkentése, valamint multifunkcionalitásának megőrzése, helyreállítása. 
A környezeti remediációs eljárások alatt minden olyan környezetvédelmi céllal végzett müszaki, gazdasági, igazgatási tevékenységet és intézkedéssorozatot értünk, amelynek a célja az, hogy a szennyező anyagok és a környezet kölcsönhatásait felügyelt feltételek mellett módosítsa és elindítson egy ellenőrzött lebontási folyamatot, amelynek eredményeként a szennyező anyag mennyisége csökken vagy veszélytelen vegyületté alakul át.

A hazai környezetvédelemben a kilencvenes évek eleje óta alkalmazzák azokat a kármentesítési (remediációs) technológiákat, amelyekkel a földtani közegek és a felszín alatti vizek eredményesen kezelhetők, illetve a bekövetkezett károk mérsékelhetők.

A szennyezőanyag(ok) tulajdonságainak függvényében számos kármentesítési eljárás ismert, amelyeknek előnyei és hátrányai meghatározzák alkalmazhatóságukat az adott helyzetben. A megfelelő kármentesítési technológia kiválasztása során a következő szempontokat kell figyelembe venni ${ }^{23}$ : a kármentesítendő közeg meghatározása; a rendelkezésre álló és kivitelezhető technológiák vizsgálata; a beavatkozás sürgősségének és több terület esetében a fontossági sorrend megállapítása; a szennyezett terület elhelyezkedése, nagysága és egyéb jellemzői; a szennyezőanyag jellemzői; a szennyezett terület szennyezőanyag kibocsátása, a szennyeződés terjedése; a szennyeződés terjedésének felmérése; a mentesítési határérték meghatározása; a remediációs folyamatok idő- és költségigénye; a kármentesítés humán és környezeti kockázata, ezek mérséklése; a kármentesített terület utóhasznosításának lehetőségei.

Az eljárásokat többféle szempont alapján csoportosíthatjuk, azonban meg kell jegyezni, hogy mivel a szennyezett közegre általában a szennyezők nagyfokú heterogenitása jellemző, így a környezetvédelmi kármentesítési gyakorlatban legtöbbször különböző technológiák kombinációját alkalmazzák. A kármentesítési módszereket lehet a tisztítási elv szerint is csoportosítani ${ }^{1,23}$ :

○ Kémiai-fizikai eljárások: a cél egyaránt lehet a szennyező komponensek immobilizálása, illetve közvetlenül a mennyiségük csökkentése. Ilyen eljárások pl. kémiai oxidáció vagy redukció, talajmosás, talajlevegőztetés, stabilizáció.

- Termikus eljárások: a beavatkozások célja lehet a komponensek immobilizálása vagy éppen ellenkezőleg, a mobilizálásának serkentése. Ilyen eljárások pl. égetés, pirolízis.

○ Biológiai eljárások: cél a szennyező komponensek mobilizálása vagy immobilizálása. Olyan beavatkozások tartoznak ide, melynek során a szennyeződés környezeti kockázat csökkentése mikroorganizmus(ok) vagy növények átalakító, biodegradáló vagy bioakkumuláló tevékenységén keresztül valósul meg, pl.biostimuláció, bioaugmentáció. 
○ Ökomérnöki eljárások: A technológiai céllal kialakított, a szennyeződés specifikumait szem előtt tartva ún. mezokozmoszt, vagyis több fajt tartalmazó vízi, sekélyvízi vagy szárazföldi ökoszisztémát alkalmaznak, pl. eleven iszapos szennyvíztisztítás, fitoremediáció.

Az eljárásokat a beavatkozás helye szerint, alapvetően két csoportba sorolhatjuk ${ }^{23}$ :

- In situ (eredeti helyzetben) eljárások: ebbe a körbe tartozik valamennyi olyan eljárás, amikor a szennyezett földtani közeget, beleértve az egyes talaj fázisokat is természetes kifejlődésük környezetéből nem távolítják el, nem termelik ki a tisztítás során.

- Ex situ (nem eredeti helyzetben) eljárások: ide tartoznak azok a beavatkozások, amelyek nem a szennyeződés eredeti helyén valósulnak meg.

Megjegyzendő, hogy szinte minden fizikai, kémiai vagy biológiai remediálási módszer alkalmazható in situ is, az alkalmazhatóságot általában a szennyezett talaj mennyisége, a hozzáférhetőség és a technológia költsége limitálja.

A klórozott alifás vegyületek további kezelést igényelnek a korábban (2.1.1 fejezet) említett káros ökológiai hatásaik megelözése, csökkentése érdekében. A már környezetbe kikerült szennyezések esetén kármentesítési eljárásokra van szükség. A nagy kiterjedésü, nehezen hozzáférhető klórozott szénhidrogénnel szennyezett területek kármentesítésénél az in situ technológiák alkalmazása az előnyös, mert:

○ helyben kivitelezhetőek,

○ lakott, beépített terület is kármentesíthető,

○ a környezet csak minimálisan változik meg, a remediáció során is hasznosítható,

○ szállítási költségeket lehet megtakarítani,

○ mivel nincs közeg kiemelés, így nem kell az esetleges hulladékok kezelésével számolni,

○ nagy hatékonyságuk mellett gyakran olcsóbbak, mint az ex-situ technológiák,

○ az egyes kármentesítési eljárások jól adaptálhatók/alkalmazhatók a szennyeződés típusához,

○ kombinálhatóak más remediációs technikával.

Az in situ remediáció hátránya, hogy a maradék szennyezettség és a köztitermékek miatt a munkálatok során fokozott kockázattal kell számolni, hiszen a szennyezett környezeti elem/fázis nincs izolálva a nem szennyezett környezettől ${ }^{24}$. 


\subsection{Klórozott alifás szénhidrogének in situ remediációs lehetőségei}

A halogénezett vegyületek korábban ismertetett széles körü felhasználása (2.1.1 fejezet) speciális tulajdonságaiknak köszönhető. A bennük lévő szén-halogén kötés igen erős, így stabilak, a kötés ereje a halogén atom növekvő molekulatömegével csökken. A halogén szubsztituens csökkenti a vízoldékonyságot és növeli a lipofil tulajdonságot, melynek következménye a biológiai hozzáférhetőség csökkenése, a felhalmozódás növekedése. A halogén szubsztituens mennyisége, formája és mérete szintén hatással van a vegyület tulajdonságaira, pl. toxicitás, mutagenitás ${ }^{25}$. A remediáció kulcsfontosságú lépése a halogénezett szénhidrogének lebontásánál a halogén atom és szénatom közötti kötés megbontása ${ }^{26}$.

Amennyiben az in situ eljárás feltételei teljesülnek, akkor a klórozott alifás szénhidrogénekkel szennyezett területek kármentesítésére az egyik legelterjedtebben alkalmazható módszerek a biodegradáción és a kémiai lebontáson alapuló módszerek. A következő pontokban ezeket ismertetjük részletesen.

\subsubsection{Bioremediáció}

A fenntarthatóság jegyében, a jelenlegi környezetvédelmi irányelveket figyelembe véve minden olyan esetben, ahol lehetséges, a biológiai módszerek alkalmazását kell előnyben részesíteni. Ezek az eljárások tekinthetőek a legtermészetesebb kármentesítési módszernek. Biodegradáció alatt a mikroszervezetek biokémiai anyagcsere folyamatain keresztül megvalósuló, lebontási (katabolitikus), illetve átalakítási (transzformációs) folyamatokat értjük. A bioremediáció során a mikrobák ezen képességeit kihasználva tudjuk a környezetszennyező anyagokat lebontani. Ezek alapján elmondható, hogy a bioremediációs technológiák közös feladatai a mikrobiális anyagcsere serkentése és fenntartása. A következő bioremediációs módszereket különböztetjük meg:

- Öntisztulás - Természetes szennyezöanyag csökkenés

Mesterséges beavatkozástól mentes, a szennyezett közegben megjelenő környezethez alkalmazkodva (adaptálódva) a kárhelyen lévő mikroszervezetek közül azok szaporodnak fel, amelyek képesek a szennyező anyag hasznosítására, lebontására.

- Biostimuláció - Természetes biodegradáció fokozása

A szennyezett területen lévő őshonos vagy a szennyezéshez már adaptálódott mikrobák növekedését és aktivitását serkentik fermentálható szerves szubsztrát vagy egyszerü elektrondonorok (pl. hidrogén, melasz, tejsavó, acetát) adagolásával. A 
további adalékok lehetnek még szervetlen tápanyagok (általában nitrogén, foszfor, kálium és élesztő kivonat), amelyek a mikrobák növekedését serkentik, pH-t szabályozó vegyületek, vagy szervetlen adalékanyagok, amelyek biogeokémiai folyamatokat stimulálnak.

- „Ösztönös” talajoltás

A módszer során a kármentesítendő közegből izolálják a degradációs tulajdonsággal rendelkező mikroszervezeteket és az - általában szelektív táptalajokon kiválogatott törzseket szaporítják, majd nagy mennyiségben visszajuttatják (inokulálják) a szennyezett közegbe.

- Bioaugmentáció - ,,Tervezett” talajoltás

Ha az őshonos mikroba populáció nem képes a szennyezők hatékony lebontására, faji szinten identifikált, ismert degradációs, patogenitási és érzékenységi stb. tulajdonságokkal rendelkező mikrobákat adagolnak a kármentesítendő közegbe.

A biológiai alapon végezhető degradációs eljárások előnyei, hogy jelentős kiterjedésű területekre is alkalmazhatóak és a szennyezett terület minimális átalakításával járnak. Nem igényelnek komolyabb infrastruktúrát, a többi kármentesítési beavatkozáshoz képest kisebb a költségigény, míg a terület eredeti élővilágával, mikroba közösségével kíméletesebbek. Hátrányuk a köztes bomlástermékek esetleges felhalmozódása, az időigényesség, valamint a környezeti tényezőktől (pl. hőmérséklet, $\mathrm{pH}$ ) való függőség. Továbbá a szennyezett közeg és a szennyező anyagok sajátosságai ezen módszerek hatékonyságát erőteljesen befolyásolják ${ }^{23}$.

\subsubsection{Biológiai remediáció klórozott szénhidrogének esetében}

A természetes rendszerek kiszámíthatatlanságának és komplexitásának köszönhetően az in situ kísérletek gyakran bizonytalan és nem meggyőző eredménnyel járnak ${ }^{27}$. Ezért azt, hogy az adott területen mely beavatkozás lehet sikeres, mindig az előzetes laboratóriumi mikrokozmosz kísérletek döntik el. A mikrokozmosz kísérletek során kontrollált környezetben, kis térfogatban, komplex ökológiai rendszerben vizsgálhatjuk a szennyezőanyagok sorsát, a degradációt, a mikrobiális közösség szerkezetének változásait és az esetleges beavatkozás egyéb következményeit ${ }^{23}$. Az eredmények segíthetnek megismerni és megérteni a területen zajló ökológiai folyamatokat, következtethetünk belölük a beavatkozás hatékonyságára, így megkönnyíthetik a remediáció megtervezését ${ }^{28}$. 
Éppen ezért nem véletlenül alakult ki a környezetvédelmi gyakorlatban, hogy a klórozott szénhidrogénbontó közösség ujjlenyomat-mintázatának változását is gyakran követik mikrokozmosz kísérletek segítségével laboratóriumi körülmények között ${ }^{29}$.

Bár évtizedekig a halogén atomot tartalmazó szerves vegyületeket kizárólag antropogén eredetünek tartották, az utóbbi években több mint 3000, természetes úton keletkezett halogénezett szénhidrogént azonosítottak $^{30}$. Emellett kimutattak reduktív dehalogenációt végző mikrobákat természetes környezetben ${ }^{31}$. Ezen eredmények alapján elmondható, hogy - az addig xenobiotikumnak tartott - halogénezett szerves vegyületek bioremediációs folyamataiban érdemes a dehalogenációt végző mikrobákra fókuszálni.

A biodegradációs folyamatok során a mikrobák (baktériumok és gombák) a lebontani kívánt vegyületet átalakíthatják és hasznosíthatják, mint szénforrást (osztódás, szaporodás céljából), vagy mint energiaforrást (ATP szintézis, energiatermelés céljából), illetve ún. aspecifikus, kometabolikus reakciókban (sem szénforrásként, sem energiaforrásként nem hasznosulnak). Energetikai szempontból a biodegradáció olyan elektronátadási folyamat, melyben a szerves anyagok szén- és energiaforrásként hasznosulhatnak, az oxidációjukból nyert energia pedig a sejtek felépítéséhez és azok fennmaradásához járul hozzá. Az elektronátadáshoz és az anyagcseréhez azonban szükség van elektronakceptorra is, mely az elektront felveszi. Az aerob biodegradáció során az oldott oxigén szolgál elektronakceptorként a mikroorganizmusok számára, míg az anaerob lebontási folyamatoknál molekuláris oxigén hiányában az anaerob mikroorganizmusok alternatív elektron-akceptorokat felhasználva oxidálják a környezetükben feldúsuló szerves anyagokat. Ebből adódóan a denitrifikáló mikroorganizmusok nitrátot, nitritet, a fémredukáló mikroorganizmusok mangán- vagy vas-oxidokat, a szulfátredukáló baktériumok szulfátot és a metanogén baktériumok szén-dioxidot használnak elektronakceptorként. Az elektrontranszport lánc révén minden olyan elektrondonor-elektronakceptor redox pár felhasználható energiatermésre, amelyek légzési láncba csatolásával legalább egy protonnyi proton hajtóerő jön létre. A halogénezett szénhidrogének reduktív deklorinációja során maga a halogénezett szénhidrogén vegyület a végső elektronakceptor, így e lebontási folyamatot általánosan dehalorespirációnak is nevezik. A folyamatban például klór esetén, a klór szénnél magasabb elektronegativitásából adódóan $\left(\mathrm{EN}_{\mathrm{Cl}}=3 ; \mathrm{EN}_{\mathrm{C}}=2,5\right)$ a szerves molekulában nem a szén, hanem a klór veszi fel az elektront. 


\subsubsection{Klórozott alifás szénhidrogének biodegradációja}

A klórozott etilének közül a PCE, TCE mikrobiológiai úton történő lebontása redukció útján lehetséges, a DCE és VC oxidatív (ún. aerob) és reduktív (ún. anaerob) körülmények között is lebontható ${ }^{32}$. A mai napig nem írtak le olyan szervezetet, mely aerob körülmények között képes volt a PCE-t és a TCE-t, mint egyedüli szénforrást hasznosítani.

A szennyezett területeken általában az anaerob folyamatok dominálnak, mivel nagyobb mélységekben az oxigén már nem elérhető elektronakceptor a mikroorganizmusok számára $^{28}$. A környezeti feltételek és a mikrobiális kompetíció egyértelműen meghatározzák, mely anaerob biodegradációs folyamatok dominálhatnak (2.1. ábra). Anoxikus talajvíz rétegben a termodinamikailag kedvezőbb folyamatok jelennek meg, először a denitrifikáció, ezt követik a mangán- és a vasredukciós folyamatok, majd a szulfátredukció, végül a metanogenezis ${ }^{28}$.

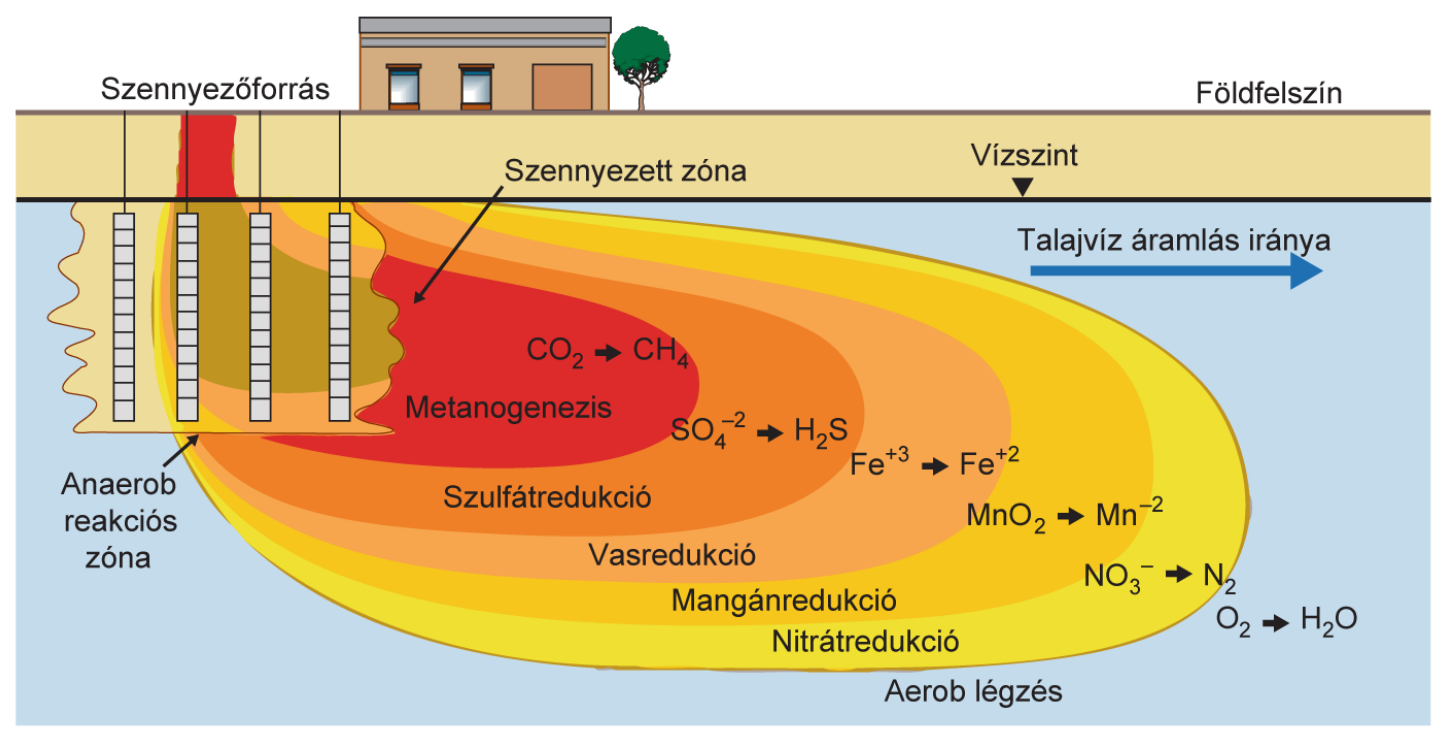

2.1. ábra. Redukáló zónák a szennyezett területen ${ }^{33}$

Számos kevert és tiszta kultúrával végzett kutatás eredménye igazolta, hogy a klórozott etilének bontásában a meghatározó anyagcsere folyamat az anaerob reduktív dehalogenáció folyamata, de előfordul oxidatív (pl. Pseudomonas stutzeri, ami az elsőként leírt anoxikus, denitrifikáló körülmények között a 2-klóretanolt szén és energiaforrásként hasznosítani képes baktérium) és fermentatív (pl. Dehalobacterium formicoaceticum a diklórmetánt fermentálja acetáttá és formiáttá) mechanizmus is oxigénhiányos környezetben ${ }^{34}$.

Mivel a dolgozatban anaerob körülmények között végeztük a vizsgálatainkat így csak az anaerob reduktív lebontást mutatjuk be részletesen. 


\subsubsection{Anaerob lebontás}

Anaerob, azaz oxigénmentes környezetben a klórozott alifás szénhidrogének lebontása ún. dehalorespiráció vagy reduktív deklorináció útján történik (2.2. ábra). Ez a folyamat végbemehet kometabolikus vagy metabolikus útvonalon.

Anaerob kometabolikus reduktív deklorinációt figyeltek meg metanogén ${ }^{35}$, acetogén ${ }^{36}$, illetve szulfátredukáló ${ }^{37}$ baktériumok esetén. Ezen anaerob baktériumok a reakciót nem energiaszerző, hanem kometabolikus útvonalon végzik, különböző enzimek vagy kofaktorok által katalizálják a reduktív deklorinációt.

Energiaszerző folyamat során a mikroba a klórozott szénhidrogént, nem szénforrásként, hanem terminális elektronakceptorként használja fel az energiatermelő folyamataiban $^{38}$.

A dehalorespiráció során a szerves szénforrás lebomlása közben felszabaduló hidrogén $\left(\mathrm{H}_{2} \rightarrow 2 \mathrm{H}^{+}+2 \mathrm{e}^{-}\right)$az anaerob klórlégző baktériumok segítségével átadódik az illékony klórozott vegyületre, amely ilyen módon reduktívan deklórozódik. Tehát a hidrogenolitikus reduktív deklorináció során a $\mathrm{PCE} \rightarrow \mathrm{TCE} \rightarrow \mathrm{DCE} \rightarrow \mathrm{VC}$ vegyületek konszekutív redukciója történik, és minden egyes lépésnél egy klorid/hidrogén ion szubsztitúció játszódik le (2.2. ábra).

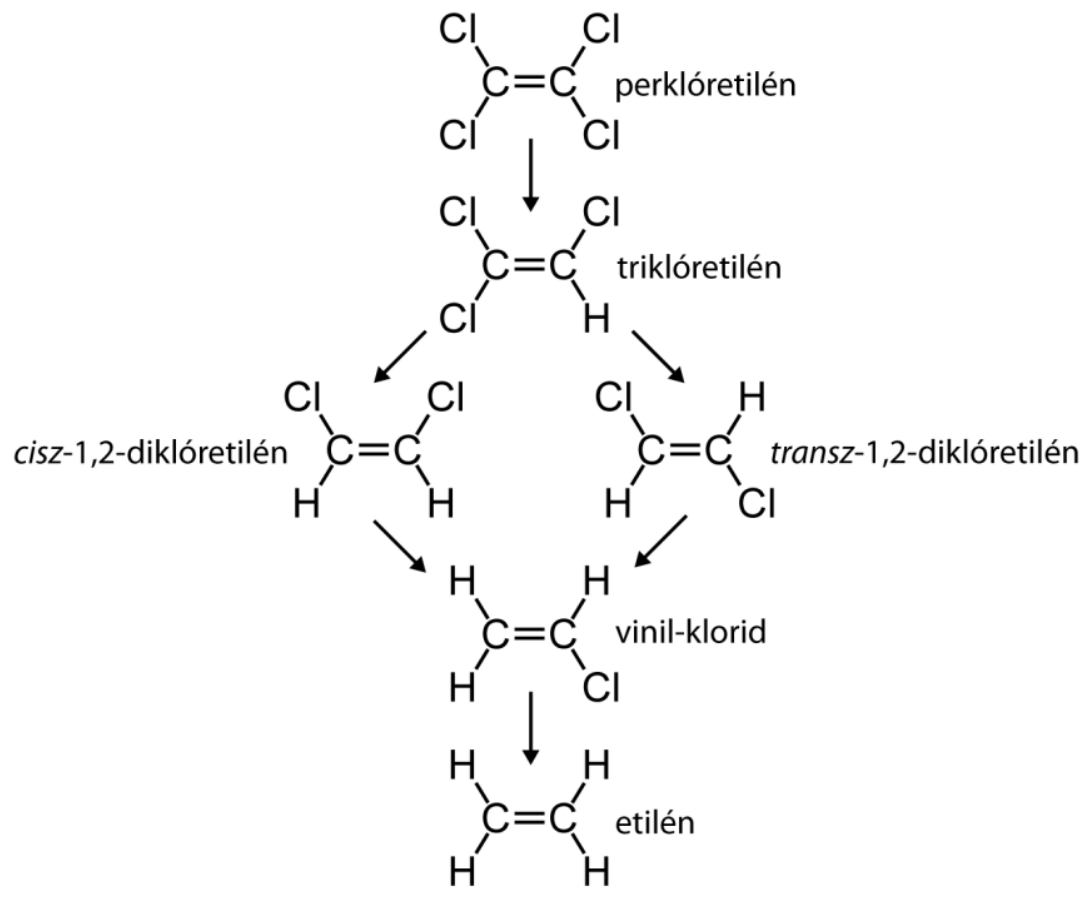

\section{2. ábra. A klórozott alifás szénhidrogének reduktív deklorinációs útvonala}

Először a Desulfomonile tiedjei törzsnél figyelték meg ezt a folyamatot, 3-klórbenzoáttal ${ }^{39}$, majd később kimutatták, hogy a törzs képes a klórozott alifás vegyületek, 
így a PCE és TCE deklorinálására is ${ }^{40}$. Azóta számos törzset azonosítottak, amelyek képesek a reduktív dehalogenáció bizonyos lépéseit végrehajtani, pl. a PCE-t, a TCE-t vagy a klórbenzoátot használják elektronakceptorként a biológiai energiaszerzésben. Ilyen baktériumok például a Dehalococcoides mccartyi (korábban Dehalococcoides ethenogenes) ${ }^{41}$, a Desulfitobacterium chlororespirans ${ }^{42}$ és a Dehalobacter restrictus ${ }^{43}$.

A kármentesítés célja a poliklórozott etilénszármazékok teljes, etilénig, illetve etánig történő lebontása ${ }^{30}$. Megfelelő mikrobiális összetétel esetén, ha kellően negatív redoxpotenciál (-200-tól $-400 \mathrm{mV}$-ig) és elegendő mennyiségü kiegészítő tápanyag áll rendelkezésre, a reduktív deklorináció elméletben teljesen végbemehet, PCE-től etilénig. Azonban gyakran tapasztalható részleges deklorináció, és ezzel párhuzamosan DCE, illetve VC köztitermékek felhalmozódása. Sokszor ez a felhalmozódás okozza a legnagyobb problémát, mivel a kevésbé klórozott etilének toxikusabbak, mint a PCE vagy a TCE ${ }^{21}$.

A Dehalococcoides mccartyi 195 volt az első és az egyetlen azonosított baktérium törzs, ami egymaga képes véghezvinni a deklorinációt: PCE-t, illetve TCE-t etilénig alakítani $^{41,44}$. Azonban itt a deklorináció során csak a VC eléréséig történik energiaszerző redukció, az utolsó lépés, ahol a VC etilénné alakul, kometabolikus és lassú folyamat ${ }^{45}$.

A Dehalococcoides sp. BAV1 az elsőként felfedezett törzs, amely képes a cDCE összes izomerjét és a VC-t, mint elektronakceptort hasznosítani ${ }^{41}$. Az utóbbi 10 évben további, a klórozott etilének bontásában résztvevő Dehalococcoides törzseket is sikeresen izoláltak, amelyeket szintén a Dehalococcoides mccartyi fajhoz soroltak. Ezek a következő törzsek: CBDB1, FL2, GT és VS ${ }^{46}$. A hat törzs (195, BAV1, CDBD1, FL2, GT és VS) 16S rRNS génjének bázissorrendje több mint 98\%-os hasonlóságot mutat. Filogenetikai elemzések alapján a Chloroflexi csoportba tartoznak (2.3. táblázat, 2.3. ábra).

\section{3. táblázat. PCE, TCE bontására képes Dehalococcoides törzsek}

Törzs

Dehalococcoides mccartyi 195

Dehalococcoides mecartyi BAV1

Dehalococcoides mccartyi FL2

Dehalococcoides mccartyi GT

Dehalococcoides mccartyi VS
Elektronakceptor

\begin{tabular}{|c|c|}
\hline $\begin{array}{l}\text { PCE, TCE, DCE, VC, klóretánok, } \\
\text { klórbenzének }\end{array}$ & $\mathrm{H}_{2}$ \\
\hline DCE, $\mathrm{VC}$ & $\mathrm{H}_{2}$ \\
\hline TCE, DCE, VC & $\mathrm{H}_{2}$ \\
\hline TCE, DCE, VC & $\mathrm{H}_{2}$ \\
\hline DCE, VC & $\mathrm{H}_{2}$ \\
\hline
\end{tabular}

Nem minden Dehalococcoides törzs képes a PCE vagy a TCE teljes deklorinációjára (2.3. ábra) ${ }^{44,47}$. Az egyes Dehalococcoides törzseket vizsgálva azt tapasztalták, hogy vannak 
olyan törzsek, amelyek az egyes klórozott alifás szénhidrogéneket más mechanizmussal bontják. P1. a Dehalococcoides FL2 törzs reduktívan deklorinálja a TCE-t és cDCE-t, viszont a PCE-t és a VC-t kometabolizmussal bontja. A Dehalococcoides BAV1 törzs pedig a DCE-t és VC-t képes terminális elektronakceptorként hasznosítani, míg a PCE-t és TCE-t kometabolizmussal bontja ${ }^{48}$.
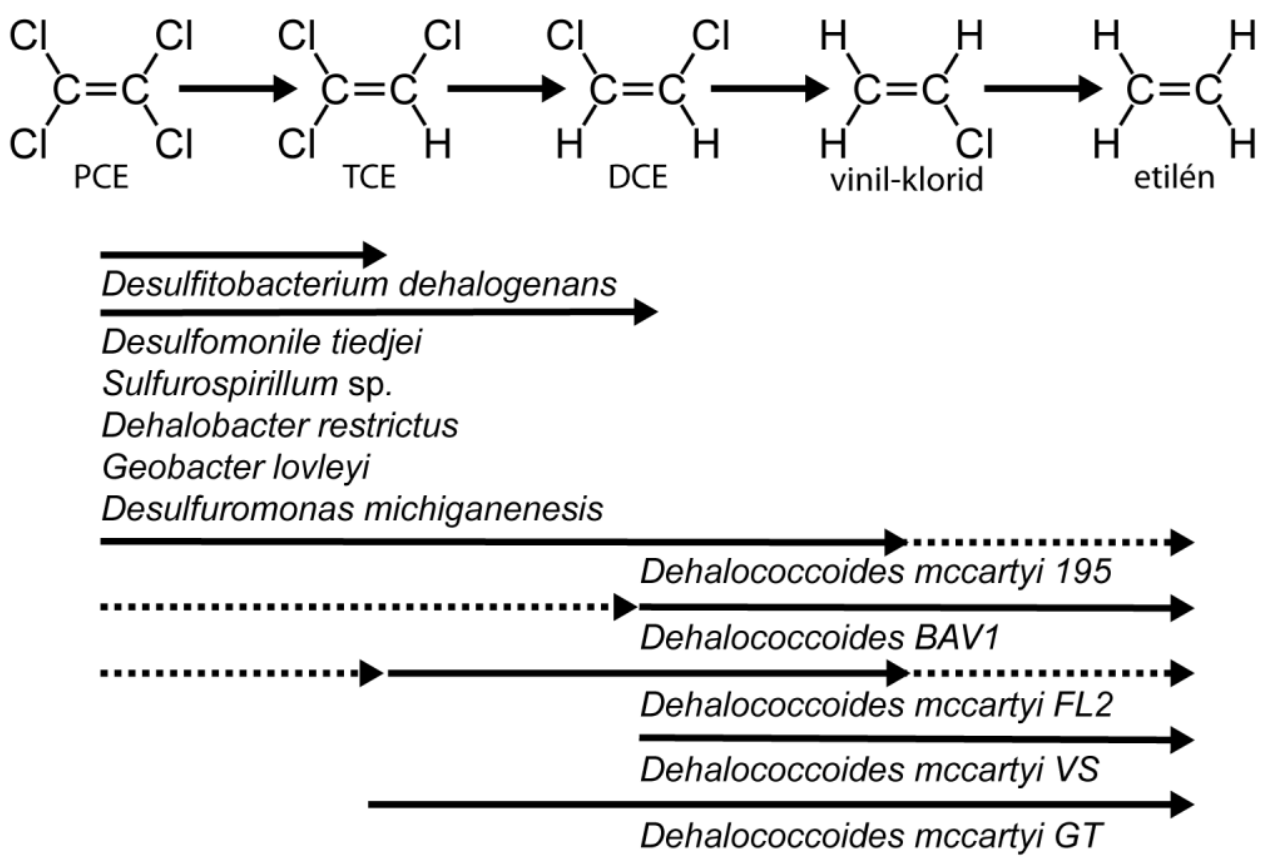

2.3. ábra. A klórozott etilének bontásában résztvevő mikrobák ${ }^{49}$

\subsubsection{Biodegradációban résztvevő baktériumok kimutatása}

A környezeti kármentesítés során kiemelt jelentőségü a degradációban résztvevő mikrobák azonosítása és jellemzése. Ezáltal meg tudjuk becsülni a mikrobák fontosságát, bontási képességét és a közösségi anyagcserében betöltött szerepét.

Habár a talajmikrobák közösségeit éveken keresztül tenyésztésen és izoláláson alapuló módszerekkel vizsgálták, ma már molekuláris biológiai módszerek használatosak, ugyanis ezek a mikrobák sokszor laboratóriumi körülmények között nem tenyészthetőek (a prokarióta fajok <1\%-a vonható tenyésztésbe), vagy a kevert kultúrák esetében annyira kevés van belölük, hogy jelenlétük nem mutatható ki hagyományos módszerrel ${ }^{50}$.

Mint korábban már említettük, az ismert Dehalococcoides törzsek közül csak a Dehalococcoides mccartyi 195-nél igazolható, hogy képes a PCE teljes deklorinációjára (PCE-től etilénig), de ezen kívül számos Dehalococcoides törzsről igazolták, hogy a deklorináció egy vagy több lépését képesek véghezvinni ${ }^{46}$. 
Egy környezeti mintánál a Dehalococcoides $16 \mathrm{~S}$ rRNS gén kimutatása egy jó indikátor arra, hogy a területen feltételezhető olyan endemikus mikroflóra, mely képes a klórozott alifás szénhidrogének deklorinációjára. A $16 \mathrm{~S}$ rDNS régió egy meglehetősen konzervált szakasz, mely az adott baktérium filogenetikai besorolására alkalmas, de a közeli rokonságban lévő törzsek esetében is vannak reprezentatív eltérések (V2 és V6 hipervariábilis régió) ${ }^{51}$. Például az egyes Dehalococcoides izolátumok 16S rRNS génszekvenciák alapján három ún. alcsoportba sorolhatóak: Cornell (ide tartozik pl. a Dehalococcoides mccartyi 195 is), Victoria (pl. Dehalococcoides mccartyi VS) és Pinellas (Dehalococcoides mccartyi BAV1, CDBD1, FL2 és GT) ${ }^{46}$.

16S rRNS gént vizsgálva, világszerte számos klórozott etilénnel szennyezett területen mutattak ki Dehalococcoides törzseket ${ }^{52}$. Ugyanakkor a Dehalococcoides 16S rRNS gén jelenléte és diverzitása nem tükrözi a tényleges deklorinációs potenciált, önmagában nem igazolja a teljes deklorináció végbemenetelét ${ }^{47}$. Az, hogy a teljes deklorináció végbemegy-e egy területen, mindig attól függ, hogy kialakult-e olyan baktérium konzorcium, mely együttesen képes a deklorináció összes lépésnek véghezvitelére. Ezért a Dehalococcoides 16S rRNS gén mellett érdemes megvizsgálni, hogy kimutathatóak-e olyan gén szekvenciák, melyek az egyes deklorinációs lépéseket katalizálják. Ilyen specifikus, katabolikus gének a reduktív dehalogenáz gének $(r d h \mathrm{~A}, \mathrm{RDáz})^{53}$. Ezek a gének felelősek a reduktív dehalogenáz enzim katalitikus aktivitásáért, amelyek a reduktív deklorináció során egy klór atomnak egy klórozott etilén molekulából történő kihasítását katalizálják ${ }^{30}$. Az első reduktív dehalogenáz, melyet izoláltak, a Desulfomonile tiedjei 3-klorobenzoát reduktív dehalogenáza volt. Számos deklorináló Dehalococcoides törzs reduktív dehalogenáz génjeit azonosították már a mai napig, azonban jelenleg csak keveset tudunk a Dehalococcoides és RDáz gének változásáról, diverzitásáról terepi körülmények között.

Ismert reduktív dehalogenáz enzimet kódoló gének:

- pceA gén (PCE reduktív dehalogenáz; amely a perklóretilén (PCE) RDáz enzimet kódolja, izolálták és azonosították a Dehalococcoides mccartyi 195, és a Dehalococcoides sp. CBDB1 törzsekben, valamint Dehalospirillum multivorans-nál $\left.l^{44,54}\right)$;

- tceA gén (TCE reduktív dehalogenáz; amely a triklóretén (TCE) RDáz enzimet kódolja, megtalálható a Dehalococcoides mccartyi 195 és FL2 törzsek genomjában $^{54,55}$ );

- $\quad$ crA gén (vinil-klorid reduktív dehalogenáz; amely a vinil-klorid (VC) RDáz enzimet kódolja, izolálták és azonosították a Dehalococcoides sp. VS és GT törzsekben ${ }^{56,57}$ ); 
- $\quad b v c$ A gén (vinil-klorid reduktív dehalogenáz; amely a vinil-klorid (VC) RDáz enzimet kódolja, izolálták és azonosították Dehalococcoides sp. BAV1 törzsben ${ }^{54}$ ).

A felsorolt gének mind egy-egy redukciós lépésért, egy-egy dehalogénezésért felelős enzimet kódolnak.

Az esetek többségében a talajok tartalmaznak egy természetes anaerob mikroflórát, ahol anoxikus körülmények között, aktív szulfátredukáló és metanogén szervezetek is okozhatják a PCE és TCE vegyületek redukcióját cDCE-ig. A problémát sok esetben az okozza, hogy a deklorinációs útvonal a cDCE-nél vagy VC-nál leáll. Ezért érdemes olyan enzimkódoló gének vizsgálatát is elvégezni, melyek a cDCE és azt követően a VC redukciójáért felelős enzimek jelenlétét igazolják $(v c r \mathrm{~A} \text { és } b v c \mathrm{~A})^{53}$. Ezen enzimek detektálásával kimutatható, hogy a vizsgált környezetben van-e olyan baktérium, amely képes a reduktív deklorináció során a cDCE és a VC átalakítására.

\subsubsection{Kompetitív mikroorganizmusok a reduktív deklorináció során}

A közeg fizikai, kémiai jellemzői és a baktériumpopuláció összetétele mellett, a deklorináció hatékonysága nagyban függ a rendelkezésre álló hidrogén mennyiségétől, az uralkodó redox körülményektől, az elérhető elektronakceptorok és elektrondonorok mennyiségétől, illetve a szénforrás elérhetőségétől.

Sok esetben a CAH szennyezéssel érintett terület tartalmaz olyan endemikus mikroflórát, mely képes a szennyezés reduktív úton történő eliminációjára. Mivel e vegyületek elektronakceptorként vesznek részt a folyamatban, szükséges a mikrobiológiai aktivitás fokozásához elektrondonor biztosítása (ún. biostimulációs eljárás alkalmazása). Az elektrondonor vegyületek elsősorban hangyasav vagy hidrogén, melyet anaerob fermentatív szervezetek cukrok, szerves savak vagy alkoholok lebontásával biztosítanak.

Az elektrondonorok azonban nem csak a deklorinációt végző mikroflóra aktivitását segíthetik, hanem olyan egyéb endemikus baktériumok szaporodását is, melyek az alkalmazott elektrondonor vegyületet képesek hasznosítani ${ }^{58}$. Ilyenek például a metanogén, acetogén vagy szulfátredukáló baktériumok, melyek kompetitív szervezetek lehetnek a deklorinációt végző mikrobák számára. Ha az adott területen a nem megfelelő mikroflóra feldúsítása történik, az nemkívánatos végtermékek (pl. metán, kénhidrogén stb.) keletkezéséhez vagy a részleges deklorinációból keletkező toxikus metabolitok felhalmozódáshoz vezethet.

A reduktív deklorinációban kulcsfontosságú elektrondonor a hidrogén. A felszín alatti közegben a hidrogén biztosítására legalkalmasabb módszer az anaerob fermentáció 
alkalmazása. Azonban anaerob mikroflórában a hidrogénért, mint elektrondonorért versengés alakul ki a deklorináló baktériumok és egyéb kompetitív mikrobák között. Számos tanulmányban vizsgálták, hogy a hidrogénért folytatott verseny során mely mikrobiális reakció domináns, a $\mathrm{H}_{2}$ koncentráció csökkenése alapján a következő sorrend a valószínüsíthető: acetogenezis $>$ metanogenezis $>$ deklorináció és szulfátredukció $>$ Fe (III) redukció $>$ Mn (IV) redukció $>$ denitrifikáció (2.4. táblázat).

\section{4. táblázat. $\mathrm{A} \mathrm{H}_{2}$ koncentráció határértékei}

\begin{tabular}{lcc}
\hline Reakció & $\mathbf{H}_{\mathbf{2}}$ koncentráció (nmol/L) & Hivatkozás \\
\hline Acetogenezis & 400 & Yang és McCarty $(1998)^{59}$ \\
Metanogenezis & $7-11$ & Yang és McCarty $(1998)^{59}$, Lovely $(1994)^{60}$ \\
Deklorináció & $<2$ & Yang és McCarty $(1998)^{59}$, Smatlak $(1996)^{61}$ \\
Szulfátredukció & $1-4$ & Lovely $(1994)^{60}$, Chapelle $(1996)^{62}$ \\
Fe (III) redukció & $0,1-0,8$ & Lovely $(1994)^{60}$, Chapelle $(1996)^{62}$ \\
Mn (IV) redukció & $<0,05$ & ${\text { Lovely }(1994)^{60}}^{60}$ \\
Denitrifikáció & $<0,05$ & ${\text { Lovely }(1994)^{60}}$
\end{tabular}

A legtöbb szerző egyetért abban, hogy alacsony (kisebb, mint 0,3 nmol/L) hidrogénkoncentráció kedvező a deklorinációnak, míg 5-95 nmol/L tartománynál már a metanogén baktériumok dominálnak ${ }^{63}$. Éppen ezért preferált a lassan fermentálható (alacsony hidrogénkoncentrációt biztosító), metanogén baktériumok számára nem felvehető szubsztrátok alkalmazása, mint például butirát vagy propionát vagy politejsav, illetve emulzifikált növényi olajok használata ${ }^{64}$.

A deklorináló és szulfátredukáló baktériumok közötti versengés már vitatottabb, mivel a szulfátredukció hidrogénkoncentráció küszöbértéke 1-4 nmol/L, ami már megközelíti a deklorinációnak kedvező $0,3 \mathrm{nmol} / \mathrm{L}$ értéket. A szerzők véleménye megoszlik, van, aki szerint a szulfátredukció nincs gátló hatással a deklorinációra, más szerzők szerint azonban gátló hatás léphet fel ${ }^{65}$.

Tehát a fentiek alapján elmondható, hogy a szubsztrátok és ebből keletkező elektrondonorok adagolásával szabályozható a klórozott alifás szénhidrogének lebontása. A lebontó klororespiráló közösség számára hozzáférhető hidrogén mennyiségét és arányát megfelelő körültekintéssel megállapítva, minimálisra csökkenthető a hidrogén kompetíció más mikroba csoportokkal, mint pl. metanogén, acetogén és szulfátredukáló baktériumok. A lassan felhasználódó szubsztrátok alkalmazása költségtakarékossági szempontból is előnyös, ugyanis ezzel csökkenthető a beavatkozások száma ${ }^{48}$. 


\subsubsection{Kémiai lebontás - In situ kémiai redukció}

A már említett, számos elérhető kémiai elven alapuló remediációs technológia közül a dolgozathoz kapcsolódóan a nulla vegyértékủ nanoméretủ vassal megvalósuló kármentesítési eljárást (in situ kémiai redukció) fogjuk részletesebben bemutatni ebben a fejezetben.

\subsubsection{Nulla vegyértékü vas nanorészecskék általános jellemzése}

$\mathrm{Az}$ elmúlt pár évtizedben a több tudományágat is átfogó nanotechnológiai kutatásokban robbanásszerü fejlödés következett be, melynek következményeként olyan új, nagyhatékonyságú anyagokat, illetve eszközöket ismertünk meg, amelyek jelentős segítséget nyújthatnak az iparosodott világ egyik legnagyobb kihívásával, a környezetszennyezéssel szemben. Ebbe egyrészt beletartoznak a továbbfejlesztett analitikai módszerek, újszerú adszorbensek és szennyezőanyag-kibocsátást szabályozó készülékek, valamint a korábbiaknál jobban teljesítő talaj- és talajvíz remediációs technológiák. Utóbbiak közé sorolhatók az olyan elemi állapotú fémet (ilyen pl. vas, magnézium, cink stb.) felhasználó módszerek, ahol a fém alkalmas vizes közegben, szerves komponensek (klórozott alifás, nitro-aromás, poliklórozott bifenilek, peszticidek stb.) redukciójára ${ }^{66,67}$. A szakirodalomban fellelhető adatok alapján a nulla vegyértékủ vas nanorészecskék (nZVI=nano zero valent iron, nanovas, $\mathrm{nFe}^{0}$ ) kezdettől fogva fontos szerepet játszottak a nanotechnológia környezetvédelmi alkalmazásában (nanoremediáció) ${ }^{68,69}$.

A vas nanorészecskék vizes közegben és oxigén jelenlétében kémiailag nem stabilak. Az oxigén redukciója során keletkező hidroxid-ionok és a vas oxidációja során keletkező $\mathrm{Fe}^{2+}$ ionok reakciója $\mathrm{Fe}(\mathrm{OH})_{2}$, majd $\mathrm{Fe}_{2} \mathrm{O}_{3}$ vegyületek képződéséhez vezet, ez okozza a felületi oxidréteg megjelenését is. A kialakuló külső oxidréteg miatt a nanovas részecskék héjas szerkezetüek, ahol a nagy reaktivitású fém a héjon belül, a magban található (2.4. ábra). Az ilyen nanorészecske tulajdonságait döntően befolyásolja az, hogy milyenek a héj transzport tulajdonságai és milyen a kémiai természete. Az ilyen rendszer viselkedése jóval összetettebb, mint a csak fémböl álló részecskéké, különösen akkor, ha figyelembe vesszük, hogy tulajdonságai módosulnak a környezet megváltozása során és az idő múlásával ${ }^{70}$. 


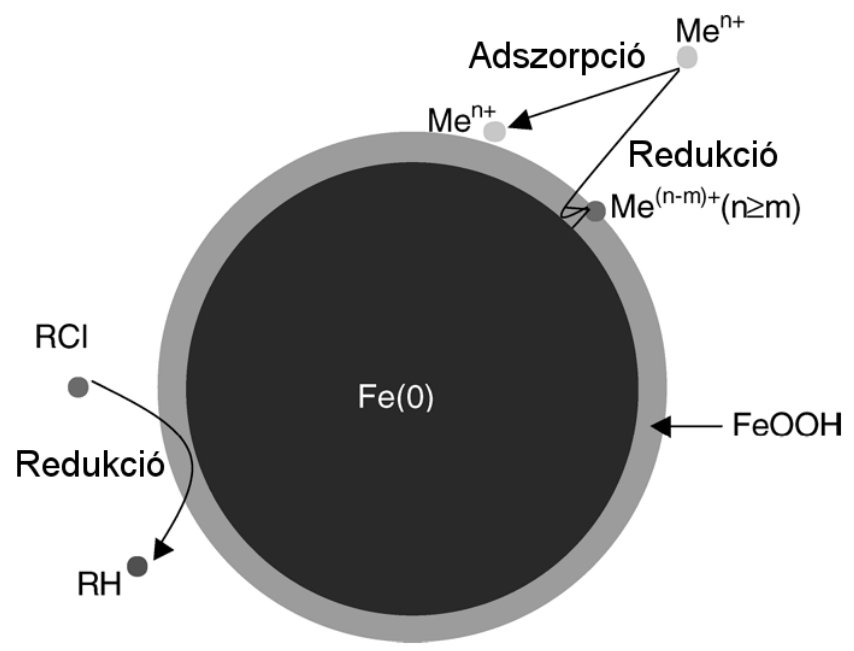

\section{4. ábra. A vas részecske héjas szerkezete, és a felületén végbemenő redukciós reakciók ${ }^{70}$}

Mindezek mellett a részecske reakcióba lép a környezetével is, a reakciópartner lehet pl. a víz vagy az oldat valamilyen egyéb komponense, illetve a jelenlévő szennyezések. Az eltelt idő itt is komoly tényező lehet. Mivel a fém vas termodinamikailag a legtöbb környezetben nem stabil, ezért várható, hogy a hosszabb távú tárolás során oxidáció vagy egyéb reakciók fognak végbemenni az anyagban. Bár a tömbfázisú vas esetén a kismértékü rozsdásodás még nem okoz jelentős változásokat az anyag tulajdonságaiban, viszont az ugyanekkora korrózió már jelentősen megváltoztatja a nanoméretű részecskék kémiai jellemzőit. Bár a vas nanorészecskéket igyekeznek inert környezetben tárolni (oxigéntől elzárva, száraz helyen, esetleg vákuumban), azonban az idő előrehaladtával így is megfigyelhető a korrodálódás következménye.

\subsubsection{Nulla vegyértékü vas nanorészecskék szerepe a környezeti remediálásban}

A nulla vegyértékű vasat $\left(\mathrm{Fe}^{0}\right)$ - részecskemérettől függetlenül - már régóta ismerik, mint kiváló elektrondonor reakciópartnert. A hétköznapi életböl a legjobb példa erre a vastárgyak oxidálódás általi korróziója. A rozsdásodás során a fém vas $\mathrm{Fe}^{2+}$ (ferro-), illetve $\mathrm{Fe}^{3+}$ (ferri-) ionná oxidálódik a levegőben lévő oxigén hatására, ami eközben vízzé redukálódik. Érdekes módon, miközben a vas korróziójának káros hatása évezredek óta ismert, ugyanennek a folyamatnak a környezettechnológiai alkalmazása egészen az 1980-as évek közepéig váratott magára ${ }^{71}$. Miután megfigyelték, hogy a talajvízmintákban található, klórozott szénhidrogént tartalmazó oldószerek vasból és acélból készült tárgyak jelenlétében 
elbomlanak, gyorsan megnőtt az érdeklődés a viszonylag olcsó és nem toxikus vas, mint potenciális talajvíztisztító anyag iránt ${ }^{72}$.

A nulla vegyértékü vas nanorészecske újfajta lehetőséget teremt a szennyezett talaj és talajvíz kezelésében. Kis (0-100 nm közötti) méretükből adódóan a vas nanorészecskék nagyon reaktívak (sokkal reaktívabbak, mint a szemcsés vas, aminek használata bevett módszernek számít a reaktív gátaknál), így sokkal könnyebb őket eljuttatni a szennyezés helyére, segítségükkel megoldható a szennyezések in situ ártalmatlanítása is. A nanorészecskéknek közvetlenül a felszín alá történő bejuttatása sikeres módszernek bizonyult: segítségükkel hatékonyan alakíthatóak át a klórtartalmú szerves anyagok is ${ }^{73}$. A nagyobb reakcióképesség következtében hígabb szuszpenzió formájában alkalmazhatóak, ami jelentősen megnöveli az egy pontban történő bejuttatás hatásterületét, vagyis sokkal kevesebb injektálópontot kell kialakítani, mint a szemcsés vas alkalmazása esetén, és lényegesen kevesebb vas bejuttatására van szükség. A gyors reakció miatt, kevésbé költséges, rövidebb kezelési idő szükséges. A redukció eredményeként nem-toxikus végtermékek keletkeznek (pl. TCE lebontása során etán a végtermék ${ }^{74}$ ). Az in situ kezelés miatt kevesebb felszerelésre és felszíni berendezésre van szükség, ami csökkenti a költségeket, illetve az embereket és környezetet is kevesebb hatás éri. Ezenkívül a nanovas alkalmazásával gyorsabb lebontást (pl. TCE lebontásánál) figyeltek meg a szintén remediációban használt szemcsés vas alkalmazásával szemben ${ }^{75}$. További előnye, hogy a nanorészecskék olyan reakciókban is részt vehetnek, amelyek a szemcsés vasra nem jellemzőek, mint például a poliklórozott bifenilek lebontása ${ }^{76}$.

A nanorészecskék emellett nagyon rugalmasan használhatók fel, akár in situ, akár ex situ helyzetben. Például a nanorészecskék könnyen elhelyezhetők zagyreaktorokban, ahol hatékonyan képesek részt venni a szennyezett talaj, az üledék és a szilárd hulladék kezelésében. Egy másik lehetőség az, ha a nanorészecskéket szilárd hordozóhoz rögzítjük, pl. aktivált szénhez vagy zeolithoz, az így kapott anyag felhasználható a víz, a szennyvíz vagy éppen gázelegyek megtisztítására is ${ }^{77,78}$.

Az évek során számos, különböző tulajdonságokkal rendelkező nanorészecskét sikerült előállítani, és a már ismert szintézismódszereket jelentősen továbbfejlesztették. Továbbá, rengeteg laboratóriumi és helyszíni kísérletet végeztek el, és egyre több szennyezö anyag ártalmatlanítására találták meg a megfelelő technológiát. Ennek eredményeként a vas nanorészecskék mára a környezetre ártalmas vegyületek jelentős részével szemben hatékonyan alkalmazhatóak: a nanovas nagyon ígéretes a nehézfémek (pl. $\mathrm{Cr}(\mathrm{VI}), \mathrm{Hg}^{2+}$ és $\left.\mathrm{Ni}^{2+}\right)$ és a radionuklidok $\left(\mathrm{UO}_{2}{ }^{2+}\right)$ immobilizálása szempontjából, továbbá felhasználható 
klórtartalmú vegyületek (pl. klórozott etének/etánok, klórbenzolok, bifenilek), peszticidek (pl. DDT, lindán), vagy szervetlen anionok (pl. perklorát, nitrát) ártalmatlanítására is 9,66,68,69,79.

\subsection{A nulla vegyértékü vas hatásának kémiai alapjai}

Az elemi vas $\left(\mathrm{Fe}^{0}\right)$ közepesen erős redukálószer, vagyis képes elektrondonorként viselkedni a megfelelő reakciópartnerrel szemben:

$$
\mathrm{Fe}^{2+}+2 e^{-} \rightarrow \mathrm{Fe}^{0}
$$

A nulla vegyértékű vas és a $\mathrm{Fe}^{2+}$ ionok által alkotott redoxi pár standard elektródpotenciálja $\left(\mathrm{E}^{0}\right)-440 \mathrm{mV}$, ami lehetővé teszi, hogy a vas, számos, a környezetben előforduló vegyülettel reakcióba lépjen. Ilyenek például a hidrogénion (proton), az oldott oxigén, nitrátok, szulfátok vagy karbonátok ${ }^{80}$. Aerob körülmények között például a vas az alábbi reakció szerint reagál az oldott oxigénnel:

$$
2 \mathrm{Fe}_{(s z)}^{0}+4 \mathrm{H}_{(a q)}^{+}+\mathrm{O}_{2(a q)} \rightarrow 2 \mathrm{Fe}_{(a q)}^{2+}+2 \mathrm{H}_{2} \mathrm{O}_{(f)}
$$

Ennek a reakciónak $25^{\circ} \mathrm{C}$-on a teljes redoxpotenciálja $+1710 \mathrm{mV}$, ami azt jelzi, hogy termodinamikai szempontból nagyon kedvezményezett folyamatról van $\operatorname{szó}^{81}$. A sztöchiometria szerint a reakcióban négy elektron szabadul fel a vas felületéröl, és a protonfogyasztás miatt növekszik az oldat $\mathrm{pH}$-ja. Ha további oldott oxigén is jelen van, akkor a képződött $\mathrm{Fe}^{2+}$ ionok továbboxidálódnak $\mathrm{Fe}^{3+}$ ionokká. A megnövekedett $\mathrm{pH}$ azonban kedvez a vas-hidroxid és a karbonát alapú csapadék kiválásának, ami passziválhatja a reaktív fém felületét ${ }^{80}$.

Anaerob körülmények között, de legalábbis a talajvíz kisebb oldott oxigén szintje esetén a víz fogja oxidálni a fém vasat, aminek következtében a $\mathrm{Fe}^{2+}$ mellett hidroxidion és hidrogéngáz is keletkezik:

$$
\mathrm{Fe}_{(s z)}^{0}+2 \mathrm{H}_{2} \mathrm{O}_{(f)} \rightarrow 2 \mathrm{Fe}_{(a q)}^{2+}+\mathrm{H}_{2(g)}+2 \mathrm{OH}_{(a q)}^{-}
$$

Az oldott oxigén redukciójával ellentétben a vízzel való reakció termodinamikailag nem kedvező, ahogy azt a $-390 \mathrm{mV}$-os standard redoxpotenciál is jelzi ${ }^{81}$. Továbbá, ez és más, természetes vizekben végbemenő reakciók kinetikai szempontból elég lassúak, és általában nem jutnak el a kémiai egyensúly állapotába ${ }^{82}$. 
A (2.2) és (2.3) egyenletek alapján elmondható, hogy a vas részecskék adagolásának hatására jelentősen megnő a rendszer $\mathrm{pH}$-ja és lecsökken a redoxpotenciálja. Erősen redukáló környezet jön létre, mivel a vas elfogyasztja az oxigént és más oxidálószereket a rendszerből, és a reakciókban $\mathrm{H}_{2}$ gáz keletkezik.

A laboratóriumi kísérletekkel szemben a természetes környezetben a $\mathrm{pH}$ és a redoxpotenciál változása nem mindig ilyen nagymértékü, mivel a diffúzió és a keveredés igyekszik visszaszorítani ezeket a hatásokat. A $\mathrm{pH}$ növekedése és a redoxpotenciál csökkenése kedvez az anaerob mikroorganizmusoknak, ami gyorsabb biodegradációt tesz lehetővé. A képződő hidrogéngáz és a $\mathrm{Fe}^{2+}$ ionok szintén előnyösek lehetnek ebből a szempontból. Ezért a kármentesítésben a szennyezőanyagok lebontására a nulla vegyértékü vas alkalmazásának bioremediációval való kombinálása egy optimális technológiát feltételez.

A leggyakrabban előforduló természetes elektronakceptorok mellett a vas reakcióba lép számos redukálható szennyező anyaggal is. A kármentesítés reduktív folyamatában a szennyező és a reaktív vas közötti kémiai termodinamikai egyensúly hiányát használják fel. Minél nagyobb a redoxpárok standard redoxpotenciál értékei közötti különbség, annál nagyobb a termodinamikai hajtóerő. A perklóretilén reduktív dehalogénezése például (a PCE/TCE redoxpár $\mathrm{E}^{0}$-értéke $\left.\mathrm{kb} .580 \mathrm{mV}\right)$ vassal $\left(\mathrm{Fe}^{0} / \mathrm{Fe}^{2+} \mathrm{E}^{0}\right.$-értéke $\mathrm{kb}$. $\left.-440 \mathrm{mV}\right)$ sokkal spontánabban zajlik le, mint a diklóretilén vinil-kloriddá való redukálása (cDCE/VC $\mathrm{E}^{0}$-értéke kb. $360 \mathrm{mV}$ ). Az első esetben a potenciálkülönbség kb. $1020 \mathrm{mV}$, a másodikban $\mathrm{kb}$. $800 \mathrm{mV}^{83}$.

\subsection{Nulla vegyértékủ vas alkalmazása klórozott szénhidrogének kármentesítésében}

Számos jól bevált technológia ismert az illékony szerves anyagok ártalmatlanítására, de csak nagyon kevés olyan megoldás ismert, amellyel megoldható a sűrü, nem vízfázisú folyadékok (DNAPL) eltávolítása. Mint már említettük (2.1.1 fejezet), a klórozott szénhidrogének okozta szennyezések nehezen kezelhetőek, mivel ezek az anyagok hidrofóbok és nagyon perzisztensek. A felszín alatt egyre messzebb jutnak el, és lassan beleoldódnak a talajvízbe. Mivel diffúziókontrollált folyamatokról van szó, ez az oldódás akár évtizedekig is eltarthat.

A szakirodalmi adatok alapján a nulla vegyértékü nanovas szemcsék klórozott vegyületek in situ környezeti remediálásban betöltött vezető szerepe vitathatatlan ${ }^{68,69,80,84,85}$. A következőkben a vas részecskék ezen vegyületek lebontásában vizsgált szerepét ismertetjük részletesebben. 
A vegyületcsalád reakciójának standard redoxpotenciálja a +500 és +1500 mV közötti tartományban változik, így vassal történő redukálásuk termodinamikailag kedvezményezett ${ }^{80}$.

A klórozott szénhidrogének lebontása többféle redukciós útvonalon is végbemehet ${ }^{86}$. Közülük az egyik a hidrogenolízis vagy reduktív dehalogénezés, amelynek során a halogénatomok egymást követő lépésekben cserélődnek ki hidrogénre. Egy általános, klórozott alifás szénhidrogén $(\mathrm{RCl})$ hidrogenolízise a következőképpen zajlik:

$$
\mathrm{Fe}^{0}+\mathrm{RCl}+\mathrm{H}^{+} \rightarrow \mathrm{Fe}^{2+}+\mathrm{RH}+\mathrm{Cl}^{-}
$$

Ez az útvonal a halogénezett metán ${ }^{80}$ és ecetsav ${ }^{87}$ származékok redukálásánál tekinthető domináns reakciónak. A perklóretilén (PCE) hidrogenolízis útján történő teljes deklórozásához több lépésre van szükség: a PCE-ből előbb triklóretilén (TCE), majd diklóretilén (DCE), vinil-klorid (VC), végül pedig etilén, majd etán keletkezik ${ }^{86}$. Ez a reakciósor a 2.5. ábra folytonos nyilai mentén követhető végig.

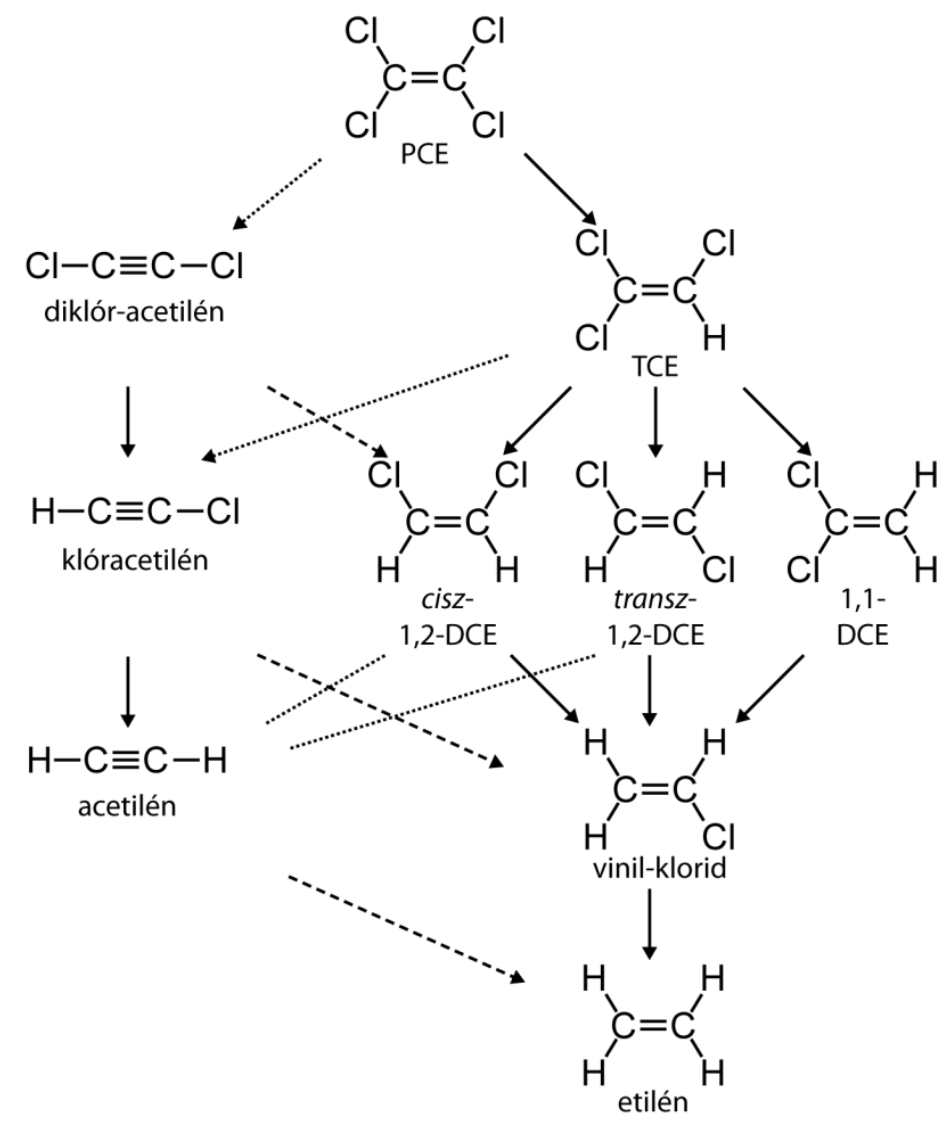

\section{5. ábra. A PCE deklórozásának lépései: hidrogenolízis (folytonos nyíl), $\beta$-elimináció (pontozott nyíl) és hidrogénezés (szaggatott nyíl) ${ }^{79}$.}


Ezeknél a reakciólépéseknél különösen fontosak az egyes reakciók relatív sebességei, mivel ezek határozzák meg, hogy egyes perzisztens és veszélyes köztitermékek (pl. a vinil-klorid) felhalmozódnak-e. Mint ismertettük ez a lebontási útvonal jellemző a bioremediációban is.

A dehalogénezés másik fontos útvonala két halogénatom együttes eliminációjával játszódik le, amelynek során a klóratomok hátrahagynak egy-egy elektront, amiből a szénatomok között $\pi$-kötés jön létre. Ha a reakcióban szomszédos szénen lévő klóratomok eliminálódnak, akkor vicinális dehalogénezésről vagy $\beta$-eliminációról beszélünk. A PCE bomlásának $\beta$-eliminációs lépéseit a szaggatott nyilak jelzik (2.5. ábra). A vassal végzett redukálás 70-90\%-ban $\beta$-eliminációs lépéseken keresztül zajlik le elsősorban akkor, ha a szennyező anyag közvetlenül érintkezhet a vassal. Általánosságban a vicinális dihaloalkénekből alkinek, a vicinális dihaloalkánokból pedig alkének jönnek létre ${ }^{79}$; a TCE $\beta$-eliminációja során például az első lépésben klóracetilén keletkezik.

A két fö reakciótípus mellett további, kisebb jelentőségü reakciók is szerepelnek a deklórozási reakciósorban ${ }^{86}$. Az egyik ilyen a hidrogénezés, amelynek során hidrogén addícionálódik a szén-szén kettős vagy hármas kötésre, a másik pedig a dehidrohalogénezés, ami egy proton és egy halogenid anion eliminációjával, ezt követően pedig egy szén-szén $\pi$-kötés kialakulásával jár. A hidrogénezés akkor kap nagyobb szerepet, ha olyan kétfémes katalizátort használnak, amely a fém vas szemcsék mellett egy katalitikusan aktív fémet, pl. palládiumot is tartalmaz ${ }^{88}$. A másik folyamat, a dehidrohalogénezés nem jellemző a $\mathrm{Fe}^{0}$ reakcióira, annak ellenére sem, hogy báziskatalizált folyamatról van szó, így a vas korróziójával járó pH-növekedés felgyorsíthatja a reakciót ${ }^{86}$.

Fontos, hogy a szennyezők lebontása teljes legyen, mert ha csupán részleges, akkor átmeneti vegyületek képződnek, és ezek szintén toxikus hatásúak lehetnek a talaj mikroflórájára $^{21,89}$. A felhasznált reaktív nanovas nem specifikusan reagál a szennyezőanyaggal, hanem redukálószerként minden olyan anyaggal reakcióba lép, amely oxidált állapotban van, azaz elektronakceptor. Ez egyben azt is jelenti, hogy a redukálószer egy része nem a célvegyület ártalmatlanítására fordítódik, ezért az alkalmazott reagens mennyiségét ehhez kell igazítani a beavatkozás során. Ugyanakkor nagyfokú szennyezés esetén nagy mennyiségü redukálószerre van szükség, így a technológiák gazdaságosabbá tételére nagy az igény. 


\subsubsection{Vas nanorészecskék hatása a talajban élő baktériumokra}

A nano mérettartományba tartozó anyagok a rendkívül kis méretük következtében minőségileg új tulajdonságokkal rendelkeznek, így más környezeti kockázattal is járhatnak, mint a szemcsés megfelelöik. A méretükből adódóan megváltozott kedvező tulajdonságaikat a fizika, a kémiai és az orvosbiológia területén hasznosítják, ugyanakkor a lehetséges környezeti kockázataikkal, sokkal kisebb mértékben vagy egyáltalán nem foglalkoznak ${ }^{90}$. Ennek ellenére már több éve nagy mennyiségben használják őket és így közvetlenül, vagy közvetett utakon ki is kerülhetnek a természetbe ${ }^{91}$.

Mint ahogy bemutattuk, a nanovassal történő in situ remediáció a laboratóriumi és terepi tesztkísérletek alapján ígéretes innovatív technológiának mutatkozik. Különösen alkalmas lehet a klórozott szénhidrogénekkel szennyezett felszín alatti környezet remediációjára, mivel a közismert antimikrobiális tulajdonsága ellenére esélyes jelölt lehet egy bioremediációval kombinált kémiai lebontásban ${ }^{92}$. Ugyanakkor az alkalmazás során figyelembe kell venni azt is, hogy ez az anyag potenciális veszélyt jelent az élö környezetre: a beavatkozás során a földfelszín alá bejuttatott nanovas kapcsolatba kerülhet a felszíni vizekkel és annak élő szervezeteivel, akár toxikus hatást kifejtve, továbbá tartósan felhalmozódhat az ökoszisztémában.

Kármentesítés során, nanovas alkalmazásával sem lehetséges a talaj/talajvíz szennyeződéseket 100\%-ban eliminálni. A legtöbb szennyezett területen a kármentesítési határértékek teljesítéséhez célszerü - költséghatékonysági szempontból - végső lépésként bioremediációt alkalmazni. Ebből kifolyólag fontos megérteni, hogyan hat a nanovas a kezelt terület geokémiai viszonyaira, valamint mikrobiális összetételére és diverzitására. A vas részecskék amellett, hogy erős redukálószerek, az újabb kutatások szerint gátló vagy stimuláló hatást fejtenek ki a különböző baktériumok populációjára ${ }^{93,94}$, habár a hatások pontos mechanizmusa még nem ismert.

Lee és munkatársai bebizonyították, hogy laboratóriumi tiszta Escherichia coli (E. coli) kultúrákba mg/L-es nagyságrendü koncentrációban beadagolt nanovas baktericid hatású mind aerob, mind anaerob körülmények között semleges pH-n ${ }^{95}$. Ennek oka valószínüleg kettős: egyfelől a sejtmembrán szétesik, másrészt reaktív oxigéntartalmú szabadgyökök is keletkeznek, melyek szintén roncsolják a sejteket ${ }^{96}$. A baktericid hatás kisebb mértékű volt nagyobb vasszemcsék, nanoméretü vas-oxid szemcsék vagy öregített nanovas részecskék alkalmazása esetén. 
Li és munkatársai szerint, a nanovas részecskéken mesterségesen létrehozott, vagy természetes módon kialakult bevonatok csökkentik a toxicitást ${ }^{97}$. Fang és munkatársai kimutatták, hogy a nanovas hatására szétesik a sejtmembrán, lipid peroxidáció és DNS roncsolódás következik be ${ }^{98}$. A nanovasról felszabaduló ionok egyes enzimek inaktiválódásához vezethetnek ${ }^{99}$.

A legtöbb tanulmányban tiszta kultúrán végzett vizsgálatról számolnak be ${ }^{95,100}$. Az elérhető molekuláris biológiai módszerek egyre szélesedő tárháza lehetővé teszi a nanovasas, illetve a bioremediációval kombinált nanovasas beavatkozások kifinomultabb vizsgálatát is ${ }^{92}$. Azonban jelenleg még kevéssé ismert, hogy a különböző módszerekkel előállított nanovasas kezelés miként befolyásolja komplex rendszerek őshonos mikrobapopulációjának, úgymint a talajbaktériumok populációjának diverzitását ${ }^{101,102}$, annak ellenére, hogy ezen mikrobaközösségek számos szennyezőanyag lebontásában fontos szerepet játszanak $^{102,103}$.

Mint már említettük, bizonyos Dehalobacter és Dehalococcoides törzsek képesek a klórozott alifás szénhidrogének teljes vagy részleges deklorinációjára ${ }^{47,104}$, így a nanovas ezen baktériumokra gyakorolt hatásának feltérképezése kulcsfontosságú. Ebből a felismerésből adódóan számos publikáció született, amiben a nanovasnak anaerob környezetben végbemenő, a mikrobiológiai dehalogenizáció folyamatát stimuláló hatásáról számoltak be ${ }^{105}$. Yin és munkatársai szerint a vas anaerob korróziója során keletkező molekuláris hidrogén, amely részt vesz a szennyezőanyagok redukciójában is, felelős a stimuláló hatásért ${ }^{106}$. Ezzel ellentétben Diao és munkatársai, valamint Xiu és munkatársai azt tapasztalták, hogy $1 \mathrm{~g} / \mathrm{L}$-es koncentrációban a nanovas toxikus hatású lehet az őshonos baktériumok populációjára, gátolhatja a biológiai deklorináció folyamatát a remediáció során ${ }^{93,94}$. Tilston és munkatársai szintén gátló hatást figyeltek meg a lebontásban résztvevő baktériumok csoportját vizsgálva, és kimutatták, hogy a nanovas adagolás egyértelműen megváltoztatta a talaj mikrobiális összetételét ${ }^{107}$. Xiu kísérletei alapján azonban a TCE bontásában résztvevő baktériumokat csak kezdetben gátolta a nanovas, azonban egy idő után visszanyerték aktivitásukat ${ }^{93}$. Fajardo és munkatársai szerint a nanovas nagyobb koncentrációban való alkalmazása $(1 ; 5 ; 10$ g/L) kezdetben jelentős toxikus hatást fejtett ki a talajbaktériumok populációjára, de 2 nap után már nem volt megfigyelhető a toxikus hatás, valószínűleg a részecskék aggregálódása miatt $^{101}$. A terepi tesztek során a ,hópehely” alakú vas nanorészecskék csak rövid ideig fejtettek ki enyhén toxikus hatást a deklórozó baktériumok populációjára ${ }^{108}$.

A nanovas szulfátredukáló és metanogén baktériumokra gyakorolt hatását illetően a kutatók véleménye nem egységes ${ }^{102}$. Míg egyik tanulmányban a nanovas adagolása után a 
deklorináló baktériumok gátlása mellett a velük hidrogénért versengő metanogén és szulfátredukáló baktériumok stimulálásáról számoltak be ${ }^{59,61}$, addig egy másik publikációban a szulfátredukálókra nézve éppen a fordított hatásról olvashatunk tiszta kultúra esetében a vas nanorészecskék ugyanazon koncentrációja mellett ${ }^{109}$. Kirschling és munkatársai három különböző szennyezett területről származó mintán vizsgálták az eltérő összetételü nanovas reagensek (poliaszpartát bevonattal ellátott nanorészecskék és a reaktív nanovas részecskék) hatását mikrokozmosz rendszerekben. A kvantitatív PCR eredménye alapján arra a következtetésre jutottak, hogy a reduktív körülmények, valamint a nanovas hatására keletkezö hidrogén együttesen stimulálták a szulfátredukáló és a metanogén mikrobákat. Továbbá, a mikrokozmoszokban nem volt megfigyelhető a teljes mikrobiális abundancia csökkenése a nanovas kezelés után, sőt a biodegradálható poliaszpartát bevonat serkentő hatással volt a baktérium populációkra, valószínüleg azáltal, hogy depolimerizációjukból könnyen metabolizálható szubsztrátokhoz jutnak a mikrobák ${ }^{102}$.

Ezen eredmények alapján felmerül a kérdés, hogy a hasonló populációkon végzett hasonló kutatások eredményei hogyan térhetnek el ennyire egymástól, minek köszönhető vajon a megfigyelt különböző hatás. Lehetséges, hogy a vas nanorészecskék szintéziskörülményei nem csak a kialakult részecskék kémiai-fizikai tulajdonságait határozzák meg, hanem hatással vannak a részecskék biológiai aktivitásra is.

A fentiekben látott egymásnak ellentmondó és az ezekhez hasonló, de még ismeretlen folyamatok azonosítása, valamint a különböző módon előállított nanovasnak a mikroflórára, különösképpen a klórozott etilének deklorinációjában résztvevő baktériumokra gyakorolt hatásának megismerése kulcsfontosságú a nanovas biztonságos környezeti alkalmazásához. 


\subsubsection{Vas nanorészecskék előállítása}

Az egyre jobb teljesítménnyel rendelkező és sokszor költséghatékonyabb eljárásoknak köszönhetően a nanotechnológiát egyre gyakrabban alkalmazzák a környezeti kármentesítés során is ${ }^{110}$. A kisméretű nanorészecskék előállítására többféle mód is kínálkozik. Alapvetően kétféle stratégiát különböztetünk meg: egyrészt az ún. „top-down” eljárásokat, amelyek az anyag dezintegrálásán, méretének csökkentésén alapulnak, másrészt pedig az ún. „,bottom-up”, vagyis alulról építkező módszereket ${ }^{111}$. A vas nanorészecskék mind a kétféle megközelítéssel elöállíthatóak, de az utóbbi a gyakoribb, vagyis általában önszerveződő rendszerekről van szó. A „top-down” módszerek legnagyobb gyengéi a magas elóállítási költség, illetve, hogy speciális eszközöket igényelnek, általában lassú a szintézis és ezekkel a módszerekkel csak kis mennyiségben állíthatóak elő a nanorészecskék ${ }^{112}$. Ilyen módszer például a fém vas nanorészecskék precíziós örléssel történő előállítása golyósmalomban ${ }^{111}$. Ezzel a technikával azonban szabálytalan alakú és könnyen aggregálódó részecskéket kaptak. Egy másik „top-down” módszer a vákuumban végrehajtott porlasztásos szintézis, mely során jól lehet szabályozni a részecskék képződését, és befolyásolni a bevonat tulajdonságait is, ugyanakkor magas a költség- és eszközigénye ${ }^{113}$. A „,bottom-up” módszerek közül később ismertetünk részletesebben párat a teljesség igénye nélkül.

Hwang és munkatársai tanulmányukban rámutattak, hogy a különböző technikával gyártott nanorészecskék fizikai és kémiai tulajdonságai is eltérhetnek, és az oxid bevonat szerkezetében is találhatóak különbségek, ezért felhasználástól függően a megfelelő szintéziskörülményeket kell kiválasztani ${ }^{114}$.

Habár a vas nanorészecskék előállítása során a kémiai módszerek közül egyértelmüen a redukciós eljárásokat alkalmazzák a legszélesebb körben, egyéb eljárások is ismertek. Tekintsük át a következőkben röviden a vas nanorészecskék előállítására kidolgozott szintézismódszereket, kitérve az előállított részecskék egy-egy jellegzetes tulajdonságára.

\subsubsection{Kémia redukció}

A legelterjedtebben alkalmazott módszerek a vas nanorészecskék elöállítására a redukción alapuló szintézisek ${ }^{115}$. A redukció során prekurzorként leggyakrabban $\mathrm{Fe}^{3+}$ - és $\mathrm{Fe}^{2+}$-sókat alkalmaznak és az oldatban lévő vas-ionokat redukálják nulla vegyértékü vassá. A kiindulási vas vegyületek vizes és vagy etanolos redukálására legtöbbször nátrium-borohidridet használnak ${ }^{116}$. 
A laboratóriumi és helyszíni kísérletekben legelőször vas(III)-klorid prekurzorból kiindulva állítottak elő vas nanorészecskéket ${ }^{76,117}$. A szintézis során $0,25 \mathrm{M}$ nátrium-borohidrid oldatot adagoltak 0,045 M koncentrációjú vas(III)-klorid oldathoz lassan, folytonos kevertetés mellett úgy, hogy a két oldat térfogata közel megegyezett. A kevertetés kb. 1 órán keresztül tartott. A reakció az alábbi egyenlet szerint ment végbe:

$$
4 \mathrm{Fe}_{(a q)}^{3+}+3 \mathrm{BH}_{4(a q)}^{-}+9 \mathrm{H}_{2} \mathrm{O}_{(f)} \rightarrow 4 \mathrm{Fe}_{(s z)}^{0}+3 \mathrm{H}_{2} \mathrm{BO}_{3(a q)}^{-}+12 \mathrm{H}_{(a q)}^{+}+6 \mathrm{H}_{2(g)}
$$

Ebben az összetételben a nátrium-borohidridet 7,4-szeres feleslegben adagolták a vas(III)-mal szemben, ezzel igyekeztek biztosítani a vas kristályok gyors és egységes méretü képződését. A kapott részecskéket ezután vákuumszüréssel különítették el az oldattól, és etanollal mosták. Az így előállított vas részecskék mérete 50-200 nm volt, a fajlagos felületük kb. 33,5 $\mathrm{m}^{2} / \mathrm{g}$-nak adódott ${ }^{76}$.

A vas(II)-szulfát prekurzorként való alkalmazására két jelentős probléma miatt volt szükség. Az erősen savas és higroszkópos vas(III)-klorid használata egészségügyi és biztonsági szempontból sem ajánlott, másrészt a vas(II)-szulfát használata jóval költségkímélöbb választás. Továbbá, ha Fe(II)-t tartalmazó nyersanyagot használunk a nanovas részecskék előállításához, akkor kevesebb redukálószerre van szükség, mint a jobban oxidált Fe(III)-nál.

Zhang és munkatársai kísérletükben a vas(II)-szulfátból kiinduló szintézis során 0,50 M nátrium-borohidridet adtak $0,28 \mathrm{M}$ vas(II)-szulfát oldathoz $0,15 \mathrm{~L} /$ perc sebességgel, 1:1 térfogatarányban ${ }^{9}$. A reakció az alábbi sztöchiometria szerint ment végbe:

$$
2 \mathrm{Fe}_{(a q)}^{2+}+\mathrm{BH}_{4(a q)}^{-}+3 \mathrm{H}_{2} \mathrm{O}_{(f)} \rightarrow 2 \mathrm{Fe}_{(s z)}^{0}+\mathrm{H}_{2} \mathrm{BO}_{3(a q)}^{-}+4 \mathrm{H}_{(a q)}^{+}+2 \mathrm{H}_{2(g)}
$$

Ennél a reakciónál 3,6-szoros nátrium-borohidrid felesleget alkalmaztak, ami jóval kevesebb a fentebb említett vas(III)-kloridból kiinduló módszerhez használt feleslegnél. Emiatt a nátrium-borohidrid hozzáadását is lassabban végezték, hogy jobban tudják szabályozni a részecskék méretét. Éppen ezért a kisebb reagensigény miatti költségcsökkenést ellensúlyozta a szintézishez szükséges hosszabb idő. A képződött nanorészecskéket vákuum szürővel leszürték, majd desztillált vízzel és etanollal mosták, nitrogén alatt szárították. A kapott részecskék mérete 50-70 nm volt, továbbá 80\%-uk kisebb volt, mint $100 \mathrm{~nm}$, és $30 \%$-uk még $50 \mathrm{~nm}$-nél is kisebbnek adódott. A vas részecskék fajlagos felülete $35 \mathrm{~m}^{2} / \mathrm{g}$ volt, ami közelítőleg megegyezik a vas-kloridból előállított részecskék fajlagos felületével. 
A röntgendiffraktometriás vizsgálatok alapján mindkét típusú nanorészecske esetében az elemi vasra jellemző reflexiók domináltak, azonban mindkét minta tartalmazott kisebb mennyiségben vas-oxidokat is. Fryxell és munkatársainak vizsgálatai alapján, a vas-oxid megjelenése a levegővel való érintkezés következménye, és csak a részecskék felszínén van jelen, a vas részecskék belsejében nem található meg ${ }^{117}$. A szintézis után 48 órával elvégzett röntgendiffraktometriás mérések a vas-oxid reflexiójának növekedését mutatták, de az elemi állapotú vas jól láthatóan még mindig jelen volt. Ezért a részecskék passziválódásának elkerülése érdekében a redukciós eljárásokat inert környezetben végzik, általában nitrogén gáz bevezetésével, ez azonban jelentősen növeli a költségeket.

Wang és Zhang mindkét típusú vas részecskét sikeresen tesztelték klórozott etilének bontásában mind laboratóriumi, mind terepi teszt során. A szintézismódszereket bemutató cikket számos publikációban hivatkozták, amelyekben a hasonlóan előállított részecskéket vizsgálták, elsősorban szennyezőanyagok lebontásában. A vas nanorészecskék segítségével a környezetre ártalmas vegyületek jelentős része felszámolható, pl. megoldható a nehézfémek immobilizálása, az illékony halogénezett szénhidrogének, a nitroaromás vegyületek, vagy a szervetlen anionok ártalmatlanítása ${ }^{9,68-70,95}$.

A nátrium-borohidrid drága és veszélyes vegyszer, a vas nanorészecskék szintézise során oxidált bórvegyületek keletkeznek, melyek nagyon nehezen választhatóak el a végterméktől, miközben több országban is tilos bórvegyületeket a talajba vagy a talajvízbe juttatni $^{118}$. A kármentesítés során a vas nanorészecskék nagyobb mennyiségben való alkalmazására van szükség, így egyéb költséghatékonyabb, környezetkímélőbb, ipari méretekben is felhasználható eljárások kidolgozása indokolt.

Magas pH-n, oxigén jelenlétében a nátrium-ditionit $\left(\mathrm{Na}_{2} \mathrm{~S}_{2} \mathrm{O}_{4}\right)$ is használható a Fe(II)-sók redukálására, és ezáltal nanovas előállítására a következő egyenlet szerint ${ }^{118-120}$ :

$$
\mathrm{Fe}_{(a q)}^{2+}+\mathrm{S}_{2} \mathrm{O}_{4(a q)}^{2-}+4 \mathrm{OH}_{(a q)}^{-} \rightarrow \mathrm{Fe}_{(s z)}^{0}+2 \mathrm{SO}_{3(a q)}^{2-}+2 \mathrm{H}_{2} \mathrm{O}_{(f)}
$$

A nátrium-ditionit a nátrium-borohidridnél jóval olcsóbb és sokkal kevésbé mérgező vegyület, továbbá a vas-ionokkal reagálva nem fejlődik veszélyes hidrogén, így a kezelése is egyszerübb és a reakció köztes termékei sem veszélyes anyagok. Emellett, a passzivált nanovas részecskék redukáló kapacitását is képes visszaállítani ${ }^{119}$. Ma és munkatársai a szintéziseik során Fe(II)-klorid kiindulási vas vegyületet használva állítottak elő nanovas részecskéket, melyeket sikeresen teszteltek a triklóretilén bontásában ${ }^{121}$. Eredményeik alapján, habár a részecskék nem rendelkeztek akkora redukciós kapacitással, mint a 
nátrium-borohidriddel elöállított minták, alkalmasnak bizonyultak a triklóretilén lebontására. Továbbá, ezen részecskék előállítása 6-szor kevesebbe került, mint a borohidrides módszerrel $^{122}$.

Amellett, hogy a nátrium-ditionitos módszerben felhasznált vegyszerek olcsóbbak, mint a nátrium-borohidrides szintézis során használtak, leginkább azért tekinthető ún. „félig-zöld” módszernek az előbbi eljárás, mert nem érzékeny az oxigén jelenlétére. Így akár kezeletlen csapvíz is felhasználható a reakcióban és nincs szükség inert atmoszféra vagy költség- és energiaigényes technológiák (pl. $\mathrm{N}_{2}$ buborékoltatás, nyomásszabályozó eszközök) alkalmazására. A költségek további csökkentése érhető el egyéb olcsóbb, nem toxikus vas(II)-vegyületek (pl. vas-szulfát) alkalmazásával. Ezáltal a nátrium-ditionitos módszer egy kis ökológiai lábnyommal rendelkező, ipari méretben „Open Air” kivitelezhető technológia.

Megjegyzendő, hogy a redukciós módszerrel kétfajta fémet tartalmazó (bimetál) nanorészecske elöállítására is van lehetőség. A második fém a vas mellett lehet például a palládium, ami katalizálhatja a hidrogénnel történő redukciót. Ilyen esetben az etanollal mosott vas nanorészecskét olyan etanolos oldathoz adják, amely kb. 1\% palládium(II)-acetátot tartalmaz, amit az elemi állapotú vas redukálni fog fém palládiummá. Wang és munkatársai kutatásuk során, mikroszemcsés (mZVI), nanoméretü (nZVI) és palládiumot tartalmazó (nZVI/Pd) elemi állapotú vasat hasonlítottak össze szén-tetraklorid bontásában $^{76}$. A szén-tetraklorid lebontása tipikus példája a klórozott szénhidrogének ártalmatlanításának. A legjobb deklórozási teljesítményt a nZVI/Pd-mal sikerült elérni, ezt követte a nZVI, majd pedig a mZVI. A nZVI/Pd két nagyságrenddel gyorsabban bontotta el a szén-tetrakloridot, mint a mZVI. A három reakcióban ugyanazok a termékek képződtek (kloroform, diklórmetán és metán), de eltérő arányban. A diklórmetán - ami toxikusabb, mint a kiindulási vegyület - legkisebb százalékban a nZVI/Pd-mal végzett redukcióban keletkezett, és itt volt a legnagyobb a metán kitermelés. A nZVI/Pd jobb teljesítményét két dologra vezették vissza. Egyrészt a nZVI fajlagos felülete jócskán meghaladta a mikrométeres szemcsékét, másrészt a palládium jelenléte lehetőséget biztosít a katalitikus redukció számára is ${ }^{123}$. Xu és Zhang hasonló módszerrel sikeresen állított elő bimetál részecskéket, ahol a vas mellett a másik fém platina, nikkel, ezüst, kobalt és réz volt ${ }^{124}$.

\subsubsection{Mikroemulziós eljárás}

Mikroemulziós szintézisek során két egymással nem elegyedő fázisból hoznak létre inverz (fordított) micellás rendszert, melynek vizes fázisában a nanorészecskék kialakulásához szükséges prekurzorok vannak feloldva. Nagyon kézenfekvő megoldásról van 
szó, hiszen a mikroemulziós cseppméret szabályozásával könnyedén befolyásolhatjuk a nanorészecskék méretét is. Ezzel a módszerrel milligrammos vagy a micellák stabilizálásával (kotenzidek) akár több grammos mennyiség is előállítható. Az így előállított nanorészecskék általában monodiszperzek, viszont problémát jelenthet a részecskék elválasztása és begyüjtése, mivel ilyen körülmények között a részecskék a szuszpendált állapotot preferálják. A részecskék összegyüjtéséhez használt módszerek - pl. a micella destabilizálása - azonban a részecskék aggregálódásához vezetnek. A micella technikával előállított egyedi nanorészecskék felületét tehát szinte mindig valamilyen felületaktív anyag foglalja el.

Li és szerzőtársainak kísérletei során a V/O (inverz) mikroemulzió szerves fázisát az n-oktán alkotta, a felületaktív anyag cetiltrimetilammónium-bromid (CTAB) volt, a kotenzid pedig az 1-butanol ${ }^{125}$. A fenti elegyhez $0,1 \mathrm{M}$ koncentrációjú vas(III)-klorid vizes oldatot adtak, majd szilárd nátrium-borohidridet, ami a $\mathrm{Fe}^{3+}$ ionokat redukálta a korábban már leírt egyenlet szerint. Az előállítás teljes folyamata nitrogén atmoszférában történt. A kapott vas részecskék közel gömb alakúak és egységes méretüek voltak, az átlagos részecskeméret $10 \mathrm{~nm}$ alatt volt. Ezzel szemben a hasonló módszerrel, oldatban előállított vas részecskék mérete 20 és $70 \mathrm{~nm}$ között változott, az átlagos átmérő $50 \mathrm{~nm}$ körül volt, és a részecskeklaszterek láncszerüen helyezkedtek el. Méréseik alapján a mikroemulzióban előállított vas nanorészecskék energiadiszperzív röntgenanalízise szerint az anyag csak fém vasat tartalmazott és $5 \mathrm{~g} / \mathrm{L}$-es koncentrációban alkalmazva $100 \mathrm{mg} / \mathrm{L}$-es TCE teljes redukálásához 75 órára volt szükség.

Wang és szerzőtársai hasonló körülmények között CTAB alkalmazása mellett vas-szulfát prekurzorból kiindulva állítottak elő levegőn is stabil vas nanorésecskéket, azonban a micella destabilizálása után a részecskék könnyen aggregálódtak ${ }^{126}$. Li és szerzőtársai Tween 60 és Span 80 felületaktív anyagok együttes felhasználásával szintén vas-szulfát prekurzorból kiindulva kálium-borohidriddel sikeresen szintetizáltak monodiszperz, kerekded vas részecskéket, hasonlóan megfigyelve a részecskék aggregálódását a demulgeálás után ${ }^{127}$.

\subsubsection{Ultrahangos kezelés}

Jamei és munkatársai az ultrahangos kezelés hatását vizsgálták a vas nanorészecskék szintézise során ${ }^{128}$. Megfigyelték, hogy az ultrahangos besugárzás hatással volt a részecskék növekedésére és aggregációs hajlamára. Azt tapasztalták, hogy növelve a besugárzás teljesítményét a gömbszerü részecskékből előbb lemez alakú, majd tüszerü szerkezetek alakultak ki. Továbbá megfigyelték, hogy a besugárzás hatására csökkent a részecskék 
mérete, nőtt a fajlagos felületük és nagyobb kristályossági fokkal rendelkeztek összehasonlítva a hagyományos nátrium-borohidrides módszerrel előállított részecskékkel. Ugyanakkor a részecskék aggregációs hajlama drasztikusan nőtt a méretük csökkenésével. Andreas és szerzőtársai levegőn stabil részecskéket állítottak elő a vas prekurzor (vas-pentakarbonil) 3 órás ultrahangos kezelésével ${ }^{129}$. A szintézis során különböző étolajokat (repce és kukorica) is felhasználtak, aminek eredményeként az ultrahangos kezelés során keletkezett vas részecskék egy vegyes összetételü polimermátrixba ágyazódtak be. Ezt az anyagot azután argonban felmelegítették, és a hőkezelés hatására a polimer karbonizálódott. A vas egy része elreagált a szén bevonattal, és vas-karbid keletkezett. A kapott anyag hat hónapon keresztül stabil maradt, klórozott szénhidrogének lebontásában sikeresen alkalmazták.

\subsubsection{Elektrodepozíció}

Banerjee és munkatársai az elektrodepozíciós technika alkalmazásával szilikagéles mátrixban állítottak elő olyan $\alpha$-vas nanorészecskéket, amelyek átmérője 4,9 és $11,1 \mathrm{~nm}$ között változott ${ }^{130}$. Az elektrondiffrakciós vizsgálatok azt mutatták, hogy a vasrészecskék felületén vas-oxidból $\left(\mathrm{Fe}_{3} \mathrm{O}_{4}\right.$ vagy $\left.\gamma-\mathrm{Fe}_{2} \mathrm{O}_{3}\right)$ álló héj található. Kiindulásként vas(III)-kloridból és szilícium-dioxidból különböző összetételü géleket készítettek. Az elektrodepozícióhoz a gélekből desztillált vízzel összekeverve pasztát készítettek, amivel bevonták az alkalmazott vas katód felületét. Ezután a vas anódot a gél pasztára helyezve 10, illetve $20 \mathrm{~V}$ feszültség mellett végrehajtották az elektrodepozíciót. A különböző összetételü gélből más-más feszültségen leválasztott vas nanorészecske minták átmérőinek mediánja és a hozzájuk tartozó szórások alapján megállapították, hogy a vas részecskék mérete csökkenthető, ha növeljük a kiindulási $\mathrm{Fe}^{3+}$ koncentrációt, vagy nagyobb feszültséget alkalmazunk.

\subsubsection{Kémiai gőzfázisú leválasztás}

Choi és munkatársai a kémiai gőzfázisú leválasztás (CVD) módszerével állítottak elő közel gömb alakú, 6-25 nm átlagos átmérőjü vas nanorészecskéket ${ }^{131}$. Vas-pentakarbonilt használtak prekurzorként, ennek pirolízise eredményezte a vas szemcséket, amelyek részben elreagáltak a jelenlévő kevés oxigénnel, így oxidbevonatú vas nanorészecske keletkezett. Megfigyelték, hogy a pirolízis hőmérsékletének növelésével a minták kristályossági foka nőtt. Ugyanakkor az átlagos részecskeméret a pirolízis hőmérsékletével együtt csökkent, $400{ }^{\circ} \mathrm{C}$-on az átmérő minimális volt, a méreteloszlás pedig szimmetrikus. Ennél alacsonyabb hőmérsékleten nem sikerült előállítani a nanorészecskéket. A hőmérséklet növelésével a 
méreteloszlás egyre szélesebb és egyre aszimmetrikusabb lett. Észrevették, hogy a hőmérséklet-növelés hatására a részecskeátmérő mediánja eltérő mértékben növekszik argonban és héliumban. A növekedés azzal magyarázható, hogy a nagyobb hőmérséklet miatt a telített gőznyomás is növekszik, ami fokozza a vas részecskék növekedését. Továbbá a gázfázisú vas részecskék kinetikus energiája is megnő, így gyakoribbak lesznek az ütközések köztük, ami szintén kedvez a részecskék növekedésének. Hélium atmoszférában ez a növekedés jóval lassabb, valószínűleg a hélium nagyobb mobilitása és hővezető képessége miatt, ami miatt a vas részecskék gyorsabban kondenzálódnak.

\subsubsection{Karbotermikus eljárás}

A vas nanorészecskék karbotermikus redukcióval is előállíthatóak ${ }^{132}$. Az eljárás során valamilyen vas-oxidot (pl. a természetben előforduló vasérceket - goethit) általában szénnel, szén-dioxiddal vagy szén-monoxiddal redukálnak magas hőmérsékleten. A technológia előnye, hogy a kiindulási anyagok nagy mennyiségben, olcsón rendelkezésre állnak, ugyanakkor a magas hőmérséklet miatt költséges módszerről beszélünk.

\subsubsection{Termikus bomlás}

A termikus bontás szintén használható vas nanorészecskék előállítására ${ }^{132,133}$. Park és munkatársai vas-pentakarbonilt (vastartalmú fémorganikus prekurzormolekula) trioktil foszfin oxidhoz adagolva $320^{\circ} \mathrm{C}$-on argon atmoszférában gömbszerü részecskéket állítottak elö ${ }^{132}$. Az így előállított nanorészecskék homogén eloszlásúak és extrém kis méretủek lettek ( $2 \mathrm{~nm})$. Az eljárásnak számos hátránya van más egyszerübb technológiához képest, a kiindulási vas pentakarbonil erősen toxikus és nem stabil, továbbá a módszer energiaigényes, és jelentős mennyiségü toxikus szén-monoxid keletkezik melléktermékként.

\subsubsection{Hidrotermális eljárás}

Vas nanorészecskék előállíthatóak hidrotermális eljárással is ${ }^{134}$. Az eljárás során teflonbélésü, rozsdamentes acélköpennyel ellátott, nyomástartó autoklávokat használnak a szükséges nyomás és hőmérséklet biztosításához. Sun és munkatársai sikeresen állítottak elő glükóz és vas(III)-nitrát oldatából kiindulva $10 \mathrm{~nm}$ nagyságú szén gömbökbe ágyazott vas részecskéket, amik nitrogén atmoszférában maguktól redukálódtak. A technológia hátránya, hogy energiaigényes és az előállítás és szétválasztás viszonylag bonyolult. 


\subsubsection{Poliol módszer}

2010-ben Joseyphus és munkatársai állítottak elő először vas nanorészecskéket poliol módszer segítségével hexakloro-platina(IV)-savat használva ${ }^{135}$. Tapasztalataik alapján növelve a hexakloro-platina(IV)-sav mennyiségét, a részecskék mérete csökkent. Továbbá észrevették, hogy ha a részecskék mérete 25 nm-nél nagyobb volt, akkor kocka alakkal rendelkeztek. $25 \mathrm{~nm}$ alatt nagyfokú aggregáció volt megfigyelhető. A részecskék a polioloknak köszönhetően levegőn is stabilak maradtak. A módszer hátránya, hogy a szintézis során erősen maró anyagokat használnak.

\subsubsection{Zöld szintézis}

Mint bemutattuk, a nanorészecskék szintézise hagyományos fizikai vagy kémiai eljárásokkal rendszerint rendkívül energia-, idő- és költségigényes, mindemellett a felhasznált vegyszerek számottevő környezeti terhelést jelentenek. A fenntartható fejlődés és a környezetvédelem érdekében a terhelés csökkentésére törekvő módszerek, úgynevezett zöld kémiai eljárások nagyjából két évtizede jelentek meg új irányvonalként a vegyiparban. Céljuk, hogy felváltsák a klasszikus előállítási módszereket, illetve alternatívát kínáljanak a környezet védelmében a gazdaságosság megtartása mellett ${ }^{136}$. Ebbe a csoportba tartoznak a korábban említett ún. félig-zöld kémiai eljárások is, melyek használata kétségkívül előnyös. Azonban az ideális szintézis olyan, amely során csökkenthető vagy megszüntethető a veszélyes anyagok alkalmazása vagy képződése a nanorészecskék előállítása során, illetve kiküszöbölhető a magas energia- és költségigény (nincsenek magas hőmérséklet- és/vagy nyomásigényü reakciós lépések).

Ezeknek a szempontoknak az ún. zöld vagy bioszintézisek felelnek meg, melyek nyilvánvaló előnyeik miatt valóban egy potenciális alternatívát kínálnak a hagyományos eljárásokkal szemben. A fém nanorészecskék zöld szintézise az utóbbi évtizedben hatalmas figyelmet kapott, a témában számos publikációt olvashatunk (809000 találat a „green synthesis of metal nanoparticles" kifejezésre Google Scholar alapján). Számos olyan innovatív, környezetbarát szintézismódszert fejlesztettek ki, amellyel alacsony költség mellett, környezetkímélő és egyszerü módszerekkel állíthatóak elő fém nanorészecskék. Továbbá, a zöld szintézisek során általában környezeti hőmérsékletet és nyomást, valamint nem mérgező, környezetkímélő oldó-, redukáló- és stabilizálószereket alkalmaznak, így a hagyományos kémiai eljárásoknál kisebb ökológiai lábnyommal rendelkeznek és sokkal biztonságosabbnak tekinthetők ${ }^{137}$. 
Gyakran élő, elsősorban prokarióta (baktérium) és eukarióta (gomba, alga) szervezetek segítségével állítják elő a kívánt nanorészecskéket. A mikrobák közvetetten vagy közvetlenül szerepet játszanak számos geokémiai-biológiai folyamatban, így a talajban lévő fémek már az élet kezdete óta egyfajta természetes kapcsolatban vannak a biológiai komponensekkel is. Ezt az érdekes tényt felhasználva rengeteg publikáció született, ahol mikroorganizmusokat, vagy valamelyik aktív komponensüket felhasználva állítottak elő nanorészecskéket ${ }^{138}$. Például Kaul és munkatársai, valamint Pavani és munkatársai különböző gombák (Pochonia chlamydosporium, Aspergillus fumigatus, Aspergillus wentii, Curvularia lunata, Chaetomium globosum, Aspergillus sp.) és baktériumok (Alcaligenes faecalis és Bacillus coagulans) alkalmazásával állítottak elő vas nanorészecskéket ${ }^{139,140}$.

Sajnos a mikroorganizmusokat felhasználó szintézisek sokszor lassúak, az eljárás során alkalmazott különböző fajok elérhetősége és fenntartása körülményes, továbbá az előállított részecskék sokszor nem monodiszperzek ${ }^{141}$. A különböző növények részeiből (levél, szár, mag, gyökér, gyümölcs) készült kivonatokat felhasználó szintézisek egyszerủek, költség-, idő- és energiahatékonyak, jól reprodukálhatók, gyors és akár ipari méretben is alkalmazható eljárások ${ }^{142}$. A növényi kivonatokkal előállított nanorészecskék kialakulásának mechanizmusát többen vizsgálták ${ }^{138}$. A kutatások eredményei alapján nem egy biomolekula felelős a fémionok redukálásáért, hanem több, másodlagos metabolitban gazdag növényi komponens. Ilyen aktív komponensek a különféle enzimek, fehérjék, aminosavak, vitaminok, poliszacharidok, alkaloidok, polifenolok, flavonoidok és szerves savak, amelyek közismerten nem toxikus, biológiai úton lebontható anyagok, emellett a szintézis során segíthetik a részecskék kialakulását és gátolhatják az aggregációt, tehát a szintézisben redukáló- és stabilizálószerként is részt vesznek ${ }^{137,142}$. A fémionok növényi kivonattal történő redukálása során formálódó részecskék keletkezésének mechanizmusát már korábban bemutatták az $\mathrm{Au}^{+}$-dihidromiricetin ${ }^{143}$ és $\mathrm{Ag}^{+}$-hidrolizálható tannin ${ }^{144}$ párokon. A fémionok először komplexet képeznek a biomolekula fenolos hidroxilcsoportjaival, majd ezután fémmé redukálódnak, miközben a biomolekula egyrészről oxidálódik, másrészt sokszor stabilizálja is a részecskéket (,capping”), így nincs szükség külön stabilizálószerre a szintézis során. Az ilyen szintézisek általában nagyon egyszerüek: a fémsó oldatát a növényi kivonattal összekeverve a nanorészecskék spontán alakulnak ki. A részecskék formálódásának ideje a pár perc és egy nap között mozog a felhasznált fém-kivonat pártól függően. Azt is érdemes megjegyezni, hogy a polifenolok és flavonoidok konjugált $\pi$-elekron rendszere lehetővé teszi az elektronok donációját a hidroxilcsoportokról a különböző szabadgyökök felé, így ezek a molekulák antioxidáns kapacitással rendelkeznek, ami meghosszabbíthatja a vas 
nanorészecskék élettartamát is ${ }^{145}$. Továbbá számos vegyület, elsősorban a flavonoidok, az átmeneti fémionok hatékony kelátorai, ezzel a tulajdonságukkal csökkentik a Fenton- és Haber-Weiss reakcióban keletkező aktív oxigén intermedierek számát ${ }^{146}$. Ráadásul e vegyületek megőrzik antioxidáns és szabadgyök-befogó kapacitásukat a flavonoid-fémion-komplex kialakulása után is ${ }^{147,148}$.

A felhasznált kivonat redukáló- illetve stabilizálószer tartalma meghatározza a keletkező részecskék méretét, így a későbbi reakciókban való reaktivitását is. Ashokkumar és munkatársai megfigyelései szerint a részecskék mérete csökkent, ha növelték az alkalmazott növényi extraktum koncentrációját ${ }^{144}$. Másik tanulmányban leírtak szerint a kialakuló részecskék száma korrelált az alkalmazott növényi extraktum mennyiségével ${ }^{142}$. A bioredukálószer adagolásának ütemét változtatva alakszelektivitást figyeltek meg ${ }^{149}$.

Növényi kivonatokkal készült vas nanorészecskékre rengeteg példát találunk a szakirodalomban ${ }^{150-154}$. A zöld tea számos országban olcsón elérhető termék, így kivonatát gyakran használják vas nanorészecskék előállítására. Hoag és munkatársai 2009-ben sikeresen állítottak elő vas nanorészecskéket egylépéses környezetbarát bioszintézis útján tea (polifenolok) segítségével ${ }^{150}$. Kísérletükben zöld tea kivonatát reagáltatták vas(III)-klorid vizes oldatával pár percig szobahőmérsékleten, a reakció végén stabil nanorészecskéket kaptak. Megállapították, hogy a teában lévő polifenolok a reakció során nem csak redukálószerként, hanem stabilizálószerként is közremüködtek. Huang és munkatársai háromféle (zöld, oolong és fekete) tea kivonatával állítottak elő vas nanorészecskéket, amit malachitzöld bontásában teszteltek ${ }^{151}$. Magas polifenol/koffein tartalmának köszönhetően a zöld tea teljesített a legjobban. Machado és szerzőtársai 26 különféle növény levelének potenciális bioredukálószerként való alkalmazhatóságát vizsgálták ${ }^{152}$. Eredményeik alapján a legnagyobb antioxidáns kapacitással a tölgy, a gránátalma és a zöld tea rendelkezett, ezek kivonatával sikeresen állítottak elő vas nanorészecskéket.

Hasonlóan környezetkímélő, egylépéses szintézis útján állítottak elő vas nanorészecskéket kávé, szőlő, eukaliptusz, rózsa, henna, gardénia, illetve különböző gyümölcsfák, úgymint golgotavirág, cseresznye, őszibarack, avokádó, narancs stb. leveléből készült kivonat segítségével ${ }^{69,152,153}$. A felsoroltak és további összegző tanulmányok is rávilágítottak arra, hogy a bioredukálószer körültekintő kiválasztása nagyon fontos, mert a $\mathrm{Fe}^{3+}$ ionok redukálása nem mindig teljes, továbbá a zöld szintézissel előállított vas nanorészecskék degradációs kapacitása is sokszor alulmarad a hagyományos eljárással elöállított részecskék kapacitásához képest ${ }^{154}$. 
Mint látható a zöld szintézisek jó alternatívát kínálnak a hagyományos eljárások kiváltására. Mindazonáltal, a zöld szintézismódszerek további fejlesztésére van szükség, elsősorban olyan növények bevonásával, melyek nagy mennyiségben és könnyen hozzáférhetőek, és felhasználásuk révén a szintézis kivitelezése ipari méretekben is megoldható.

\subsubsection{Vas nanorészecskék stabilizálása}

A nanofázisú anyagok környezettechnológiai alkalmazásában a legnagyobb kihívást az aggregálódásra való hajlam, a gyors ülepedés, és a vizes közegbeli csekély mobilitás jelenti. A vas nanorészecskék aggregálódásának megelőzésére és mobilitásának növelésére egy jó megoldás lehet a részecskék felületének módosítása. A sztérikus stabilizálás (polimerrel való stabilizálás) széles körben alkalmazott módszer kolloid diszperziók előállításában: a részecskék köré épülő polimer adszorpciós réteg sztérikus stabilizálást biztosít, gátolva a részecskék aggregációját. Phenrat és szerzőtársai három anionos polielektrolit stabilizáló képességét vizsgálták, miközben az egyes polimerek moláris tömegének hatását is értékelték $^{155}$. A háromféle polimer a poli(sztirol-szulfonát), a karboximetil-cellulóz és a poliaszpartát volt. A kísérletek eredményei szerint a diszperzió stabilitása, vagyis a nem aggregálódó részecskék aránya egyaránt függ a polielektrolit felületi többletkoncentrációjától és az adszorpciós réteg vastagságától.

A vinil-alkoholból, vinil-acetátból és itakonsavból álló PV3A kopolimerrel stabilizált vas részecskéknél megfigyelték, hogy a kopolimer hozzáadása a sztérikus stabilitás mellett jelentős elektrosztatikus taszítást is eredményezett, így a részecskék várhatóan nem fognak adszorbeálódni a föleg szintén negatív töltésű talajkolloidok felületén ${ }^{156}$.

Choi és munkatársai az alkalmazott polimer (polivinil-pirrolidon - PVP) mennyiségének változtatásával értek el alakszelektív szintézist ${ }^{157}$. Vizes közegben nátrium-borohidriddel történő redukcióval állítottak elő vas nanorészecskéket. Ha az alkalmazott PVP mennyisége kisebb volt, mint 0,3\% akkor a megszokott kerekded részecskéket figyelték meg, ha nagyobb volt, mint 1\%, akkor nem alakultak ki elemi állapotú részecskék. Ha az előállítás során felhasznált PVP mennyisége 0,3-1\% között változott, akkor szálas szerkezetű nanovasat sikerült előállítaniuk. A nanoszálak méretét (átmérő: 1-10 nm és hossz: 10-1000 nm között) a polimer koncentrációjának változtatásával tudták változtatni.

Cirtiu és munkatársai megfigyelték, hogy a védőpolimerként alkalmazott karboximetil-cellulóz (CMC) mennyiségének növelésével csökkent a részecskék mérete ${ }^{158}$. A magyarázat valószínűleg az, hogy a nagyobb CMC koncentráció miatt a polimer hamarabb 
borítja be a képződő kristálygócokat, ezzel megakadályozva további növekedésüket. Zhou és munkatársai megfigyelték, hogy amellett, hogy a CMC-vel stabilizált vas nanorészecskék stabilitása és diszpergálhatósága nőtt, a polimer bevonat miatt kevésbé fértek hozzá a sejtekhez, így kevésbé bizonyultak citotoxikusnak ${ }^{159}$. Ugyanakkor Dror és munkatársai megállapították, hogy a polimer bevonat a nanovas szennyezőanyagokkal szembeni lebontási hatékonyságának csökkenését is eredményezte, ezért a kármentesítési eljárás során nagyon fontos a megfelelő stabilizálószer kiválasztása ${ }^{160,161}$. 


\subsection{Ezüst nanorészecskék előállítása zöld szintézissel}

Napjainkban a széles körü alkalmazási lehetőségeiknek köszönhetőn az ezüst nanorészecskék (AgNP, nanoezüst) előállítása és felhasználása iránti igény exponenciálisan nő (becsült termelés: több száz tonna/év) ${ }^{162}$. Az ezüst nanorészecskéket optikában, elektronikában, katalízisben, háztartási termékekben, ruházati cikkekben, kozmetikumokban, és az orvostudomány különböző területein egyre nagyobb mértékben használják ${ }^{163,164}$. Rendkívül nagymértékủ alkalmazásuk széles spektrumú antimikrobiális hatásuknak tulajdonítható, mivel képesek Gram negatív és Gram pozitív baktériumok, valamint patogén gombák elpusztítására, de emellett antivirális szerként is hatékonynak bizonyultak ${ }^{165-167}$. A nanotechnológia innovatív eredményeinek köszönhetően új stratégiák alakultak ki a rákos megbetegedések terápiáját célzó fejlesztések területén is. Számos tanulmány bizonyítja az ezüst nanorészecskék kiemelkedő tumorellenes hatását, melyet az in vitro eredmények után több in vivo kísérleti rendszerben is megerösítettek ${ }^{166,168-172}$.

A vas nanorészecskéknél ismertetett fizikai-kémiai eljárásokkal előállíthatók az ezüst nanorészecskék is. A fotokémiai, termikus, szonokémiai és mikrohullám alapú módszerek mellett a leggyakrabban az ezüst nanorészecskéket is kémiai redukcióval vagy elektrokémiai eljárásokkal állítják elő ${ }^{173}$. Azonban ezen eljárások során gyakran toxikus vegyszereket használnak, így a környezetre és az egészségre ártalmasak ${ }^{174}$. Például stabil nanoméretű ezüstöt tartalmazó kolloid oldat „bottom-up” kémiai elöállításához is gyakran nátrium-borohidridet használnak redukálószerként ${ }^{175}$. Mint már korábban bemutattuk, a nátrium-borohidrid alkalmazása amellett hogy meglehetösen költséges, oxidált bórvegyületek keletkezéséhez vezet, amelyek nehezen választhatóak el a kívánt nanorészecskéktől. Az ilyen nem kívánt kémiai anyagok jelenléte komoly korlátot jelenthet az előállított nanoméretü anyagok felhasználási lehetőségeiben és biológiai alkalmazásában. Ezek után nyilvánvaló, hogy az ezüst nanorészecskék esetében is szükség van a nanorészecskék olyan előállítási módjaira, amelyek innovatívak, kis költséggel járnak, környezetkímélők és kevesebb toxikus vegyszert használnak, valamint minimális mennyiségü veszélyes anyag keletkezésével járnak $^{137,175}$. Az utóbbi évtizedben számos, az ezüst nanorészecskék zöld szintéziséről szóló kutatás jelent meg, melyek a hagyományos kémiai eljárásoknál sokkal biztonságosabb, költséghatékonyabb és kisebb ökológiai lábnyommal rendelkező szintézismódszereket ismertettek $^{176}$. A vas nanorészecskékhez hasonlóan az ezüst nanorészecskéket is elő lehet állítani élő szervezetek vagy sejtalkotóik segítségével, azonban a növényeket alkalmazó zöld eljárások idö-, költség- és energiahatékonyabbak, továbbá a növények általában jobban 
hozzáférhetőek, így ezen módszerek esetleges ipari méretben való kiterjesztése megoldható $^{163,176,177}$.

Shankar és munkatársai az elsők között számoltak be az ezüst nanorészecskék gyors, zöld úton történő előállításáról. Kísérleteik során nagymennyiségü ezüst nanorészecskét állítottak elő gólyaorr (Pelargonium graveolens) és indiai orgona (Azadirachta indica) leveléből készült növényi extraktum alkalmazásával, melyet ezüst-nitrát vizes oldatával kevertek össze ${ }^{178,179}$. A szerzők az eljárás vitathatatlan előnyei közül a gyorsaságot emelték ki: a növényi kivonattal történő redukálás során sokkal gyorsabban alakultak ki a nanorészecskék, mint korábbi kísérleteik során, ahol mikroorganizmusokat használtak.

Egyéb növényi kivonatot is használtak már redukáló- és stabilizálószerként ezüst nanorészecskék előállítása során, például közönséges kámforfa (Cinnamomum camphora), citromfü (Melissa officinalis), közönséges paprika (Capsicum annuum), vöröskérgü fenyő (Pinus desiflora), páfrányfenyő (Ginko biloba), japán liliomfa (Magnolia kobus), keleti platán (Platanus orientalis) és bortermelő szőlő (Vitis vinifera) kivonatát alkalmazták már sikeresen ${ }^{177,180}$. Ezek a növények nagy mennyiségben tartalmaznak olyan aktív összetevőket (pl. polifenolok, flavonoidok), amelyek alkalmasak a fémionok redukciójára ${ }^{152,181}$. Baharara és munkatársai szerint az ezüst ionok redukálásáért a növényi kivonatokban lévő fenolos csoportok és a fehérjék a felelősek ${ }^{182}$. Ajita és csoportja kimutatta, hogy a növényi kivonatok aktív komponenseiben (flavonoidok, terpenoidok, fenolok, fehérjék) lévő hidroxil- és karbonilcsoportoknak tulajdonítható az ezüst ionok redukciója ${ }^{183}$. Továbbá bemutatták, hogy a fehérjék és peptidek védöbevonatot képeznek a részecskék körül, ezáltal növelik a partikulumok stabilitását és megelőzik az aggregációjukat. Nadagouda és munkatársai kávé és tea extraktum segítségével elsőként állítottak elő ezüst nanorészecskéket ${ }^{184}$. Munkájukban bemutatták, hogy a növényi kivonatok alkalmazása mellett nem volt szükség egyéb stabilizálószerre, a növényi kivonatok aktív összetevői szolgáltak mind redukáló-, mind stabilizálószerként a szintézis során. Ezt az egyszerü, egylépéses szintézismódszert kiterjesztették palládium, arany és platina nanorészecskék előállítására is. A részecskék kialakulási mechanizmusát a vas nanorészecskéknél bemutatott lépésekre bontották: 1) a fémionok a biomolekulákkal komplexet képeznek, 2) a fémionok elemi fémmé redukálódnak, 3) a 2. lépéssel párhuzamosan a biomolekula oxidálódik és stabilizálja a kialakult nanorészecskéket. Pörkölt kávé (Coffea arabica), zöld tea és fekete tea vizes-alkoholos oldatával is állítottak már elő ezüst nanorészecskéket ${ }^{181,185,186}$. A szerzők megállapították, hogy a kivonatokban lévő koffein és teofillin felelősek az előállított nanorészecskék 
stabilizálásáért. Dhand és munkatársai szerint a kávé komponensei közül a klorogénsav a legfőbb fenolos komponens, ami szerepet játszik az ezüst ionok redukciójában ${ }^{181}$.

A kiindulási fém-só oldat és Aloe vera növényi kivonat koncentrációjának változtatásával előállított ezüst nanorészecskék alak- és méretszelektivitását érték el Chandran és munkatársai ${ }^{187}$. Loo csoportja zöld tea kivonatával állított elő kerekded ezüst nanorészecskéket ${ }^{186}$. Kísérleteik során megfigyelték, hogy a kivonatok koncentrációjának növelésével a nanorészecskék mérete csökkent, miközben a számuk nőtt ${ }^{188}$.

A különböző zöld szintézisekkel előállított ezüst nanorészecskék eltérő biológiai rendszerekre gyakorolt hatását is többen vizsgálták. A különböző teafélékkel elöállított ezüst nanorészecskéknél megfigyelt profilaktikus hatást Moulton és munkatársai a részecskék felületén jelenlévő antioxidáns csoportoknak tulajdonították ${ }^{189}$. Fekete teával előállított nanorészecskék biológiai hatásainak vizsgálatakor kiderült, hogy a részecskék gátolják humán emlőrák (MCF-7) sejtek növekedését és a gátló hatás fordítottan arányos a részecskemérettel ${ }^{169}$. Mikrobiológiai tesztek során megfigyelték, hogy a zöld teával előállított részecskék kevésbé bizonyultak toxikusnak $E$. coli ellen, mint a tisztán kémiai úton előállított, nem stabilizált részecskék ${ }^{190}$. A megfigyelt kisebb mértékü toxicitást a nagyobb stabilitással magyarázták, mivel kevesebb ezüst ion tudott felszabadulni a nanorészecskék felszínéről, amit a növény aktív komponensei stabilizáltak. Hasonló eredményről számoltak be Ajita és munkatársai, vizsgálatukban a kisebb méretű nanorészecskék bizonyultak hatásosabbnak a tesztelt mikroorganizmusok ellen.

Egy 2016-ban megjelent összefoglaló tanulmányban kifejtették, hogy a különböző kivonatokkal előállított részecskék antimikrobiális hatása nemcsak a kialakult nanorészecskék méretétől és alakjától függ, hanem a szintézis során alkalmazott redukáló- és stabilizálószertől is ${ }^{163}$.

Habár a nanorészecskék zöld úton történő előállítása kiemelt figyelmet kapott az utóbbi évtizedben, csak kevés tanulmányban vizsgálták, illetve hasonlították össze az előállított nanorészecskék komplex (antibakteriális, antifungális, antivirális és citotoxikus) biológiai aktivitását, különös tekintettel a szintézis során alkalmazott különböző növényi kivonatok hatásának függvényében. Azonban a zöld úton előállított ezüst nanorészecskék mindennapi életben történő biztonságos használatához nagyon fontos felmérnünk, hogy a szintézis során használt, esetünkben növényi eredetü anyagok milyen hatással vannak a kialakult részecskék későbbi felhasználásakor, elsősorban az élő rendszerekre nézve. Az alkalmazás előtt ezért a nanorészecskék átfogó vizsgálata szükséges, hogy fel tudjuk mérni az élő rendszerekben tanúsított viselkedésüket és hatásukat. 


\section{CÉLKITÜZÉS}

Napjainkban a környezetvédelmi gyakorlat egyik leggyakoribb és legfontosabb megoldandó kihívása a felszín alatti vizek és a földtani közeg klórozott alifás szénhidrogén szennyezettségének felderítése és megszüntetése. Ehhez olyan innovatív, környezeti, gazdasági és társadalmi szempontból egyaránt előnyös technológiákra van szükség, melyek az utóbbi évek tapasztalatai alapján a nanotechnológiai kutatások segítségével oldhatóak meg. A nanotechnológia megjelenése a kármentesítési programokban - csakúgy, mint az élet egyéb területein - hatalmas mértékben felgyorsította a technológiai fejlödést, sokszor a költségek jelentős csökkentése mellett. Az elmúlt években a Szegedi Tudományegyetem Alkalmazott és Környezeti Kémiai Tanszékén többféle anyagból állítottak elő nanorészecskéket, melyek sikeresen alkalmazhatóak a különböző problémák megoldására a fizika, a kémia és a biológia tudományterületein. Ehhez kapcsolódva, doktori munkám céljául nulla vegyértékü vas nanorészecskék előállítását, morfológiájuk és felhasználhatóságuk lehetőségeinek vizsgálatát, valamint kémiai és biológiai rendszerekben való viselkedésük átfogó tanulmányozását tüztük ki.

Kutatásom kezdeti szakaszának célja különböző vas-prekurzorok és redukálószerek felhasználásával előállított vas nanorészecskéket tartalmazó szuszpenziók (nanovas szuszpenziók) előállítása volt, melyek sikeresen alkalmazhatóak klórozott szénhidrogénekkel szennyezett talajvíz in situ környezeti kármentesítésben. Továbbá a kidolgozott, optimalizált szintézismódszer megfeleljen a valós életben elvárt, alkalmazhatóságot erősen korlátozó szempontoknak: legyen gazdaságos és környezetbarát, ipari méretben hatékonyan alkalmazható, a további környezetterhelés minimalizálása mellett. Ennek megvalósításához fontosnak tartottuk,

- $\quad$ hogy alacsony költségü és jobban hozzáférhető prekurzorokat és redukálószereket keressünk, valamint a szintézis körülményeit környezetkímélöbbé és költséghatékonyabbá tegyük;

- $\quad$ hogy a hagyományos kémiai eljárások nyilvánvaló korlátai miatt zöld úton, növényi kivonatok segítségével is előállítsunk vas nanorészecskéket;

- hogy az előállított vas nanorészecskéket anyagvizsgálati módszerekkel (TEM, XRD, EDS, reaktivitás vizsgálat stb.) jellemezzük, összehasonlítsuk, ami elengedhetetlen a későbbi alkalmazási lehetőségeik felderítéséhez; 
- hogy az elóállított vas nanorészecskék illékony klórozott szénhidrogén bontó hatékonyságát laboratóriumi és terepi mérésekkel megvizsgáljuk.

Munkánk második szakaszában a vas nanorészecskék kármentesítési munkák során történő alkalmazhatóságának további feltételeit vizsgáltuk. Mivel a szakirodalomban kevés adat ismert arról, hogy a vas nanorészecskék milyen hatással vannak a talajban/talajvízben élö baktériumokra, ezért a kutatás következő célja a különböző morfológiájú és reaktivitású vas nanorészecskék anaerob baktériumokra (különös tekintettel a reduktív deklorinációban résztvevő baktériumok populációjára) gyakorolt hatásának tanulmányozása, esetleges toxicitásának kimutatása volt. Ennek megállapításához

- mikrokozmosz rendszerekben, az illékony klórozott szénhidrogének összetétel változásának monitorozása mellett, DNS alapú mérésekkel kívántuk megvizsgálni, hogy a különböző tulajdonságú vas nanorészecskék hogyan és milyen mértékben befolyásolják a kármentesítés során kezelt közeg mikroflórájának összetételét.

Végül munkánk harmadik szakaszában a különböző módon előállított vas nanorészecskéknél megfigyelt kémiai és biológiai rendszerekre gyakorolt hatás szélesebb körü vizsgálatához szükségesnek gondoltuk,

- $\quad$ hogy összehasonlításként szintén zöld módszerekkel, növényi kivonatokkal előállítsunk nulla vegyértékű ezüst nanorészecskéket;

- $\quad$ hogy a különböző növényi kivonatok segítségével elöállított ezüst nanorészecskék kémiai jellemzőit meghatározzuk (TEM, XRD, DLS, UV-VIS);

- hogy a kapott ezüst nanorészecskék különböző biológiai rendszerekben való viselkedését tanulmányozzuk, különös tekintettel a redukálószerek esetleges befolyásoló szerepére. 


\section{KÍSÉRLETI RÉSZ}

\subsection{A kísérleti munka során felhasznált anyagok}

\section{Vas nanorészecskék előállításához felhasznált anyagok}

Vas(II)-klorid 4-hidrát $\left(\mathrm{FeCl}_{2} \times 4 \mathrm{H}_{2} \mathrm{O}\right)$, Sigma-Aldrich Kft., $98 \%$

Vas(III)-klorid 6-hidrát $\left(\mathrm{FeCl}_{3} \times 6 \mathrm{H}_{2} \mathrm{O}\right)$, Sigma-Aldrich Kft., $98 \%$

Vas(II)-szulfát 7-hidrát $\left(\mathrm{FeSO}_{4} \times 7 \mathrm{H}_{2} \mathrm{O}\right)$, Molar Chemicals Kft., 99,97\%

Nátrium-ditionit (vízmentes, $\mathrm{Na}_{2} \mathrm{~S}_{2} \mathrm{O}_{4}$ ), Sigma-Aldrich Kft., $82 \%$

Nátrium-borohidrid $\left(\mathrm{NaBH}_{4}\right)$, Alfa Aesar, 98\%

Nátrium-hidroxid (mikroszemcsés, $\mathrm{NaOH}$ ), Molar Chemicals Kft., 99,93\%

Kávé, Tchibo Family

Zöld tea, Twinings of London, Green Tea\&Lemon

Abszolút etanol $\left(\mathrm{C}_{2} \mathrm{H}_{5} \mathrm{OH}\right)$, Molar Chemicals Kft.

Ioncserélt és csapvíz

\section{Ezüst nanorészecskék előállításához felhasznált anyagok}

Ezüst nitrát $\left(\mathrm{AgNO}_{3}\right)$, Sigma-Aldrich, 99,0\%

Kávé, Tchibo Family

Zöld tea, Twinings of London, Green Tea\&Lemon

Ioncserélt víz

\subsection{Vas és ezüst nanorészecskék előállítása}

\subsubsection{Vas nanorészecskék előállítása félig-zöld módszerrel}

A nanovas tartalmú szuszpenziók félig-zöld elöállítása során vas(II)-klorid, vas(III)-klorid és vas(II)-szulfát vizes oldatát redukáltuk nátrium-borohidriddel vagy nátrium-ditionittal szobahőmérsékleten levegő jelenlétében illetve inert atmoszférán. A lejátszódó reakciókat következő egyenletek írják le (4.1), (4.2), (4.3), (4.4):

$$
\begin{aligned}
& \mathrm{Fe}^{2+}+\mathrm{S}_{2} \mathrm{O}_{4}^{2-}+4 \mathrm{OH}^{2-} \rightarrow \mathrm{Fe}^{0}+2 \mathrm{SO}_{3}^{2-}+2 \mathrm{H}_{2} \mathrm{O} \\
& \mathrm{Fe}^{2+}+2 \mathrm{BH}_{4}^{-}+6 \mathrm{H}_{2} \mathrm{O} \rightarrow \mathrm{Fe}^{0}+2 \mathrm{~B}(\mathrm{OH})_{3}+7 \mathrm{H}_{2}
\end{aligned}
$$




$$
\begin{aligned}
& \mathrm{Fe}^{3+}+\mathrm{S}_{2} \mathrm{O}_{4}^{2-}+4 \mathrm{OH}^{2-} \rightarrow \mathrm{Fe}^{0}+2 \mathrm{SO}_{3}^{2-}+2 \mathrm{H}_{2} \mathrm{O} \\
& \mathrm{Fe}^{3+}+3 \mathrm{BH}_{4}^{-}+9 \mathrm{H}_{2} \mathrm{O} \rightarrow \mathrm{Fe}^{0}+3 \mathrm{~B}(\mathrm{OH})_{3}+10,5 \mathrm{H}_{2}
\end{aligned}
$$

A szintézisek során a bemérendő vas-sók és redukálószerek mennyiségét a fenti egyenletek alapján határoztuk meg: a reagenseket 1:1 (nátrium-ditionittal előállított minták), 1:2 $\left(\mathrm{Fe}^{2+}\right.$ tartalmú prekurzorok és nátrium-borohidrid reakciója), illetve $1: 3\left(\mathrm{Fe}^{3+}\right.$ tartalmú prekurzorok és nátrium-borohidrid reakciója) mólarányban mértük össze. A nanovas szuszpenziókat 2500, 5000 és 10000 ppm koncentrációban is előállítottuk. Minden esetben vizet használtunk oldószerként (levegő jelenlétében csapvizet, inert atmoszférában deoxigenizált ioncserélt vizet), a reakciók végtérfogata $250 \mathrm{~mL}$ volt. A szintézis során intenzív keverés mellett (Velp Scientifica, Stirrer ES keverőmotorhoz rögzített üveg keverőbot) az elkészített vas-só-oldatokhoz először megfelelő mennyiségű nátrium-hidroxid oldatot (lúgos közeg biztosítására), majd a megfelelő redukálószer oldatát adtuk. A nátrium-borohidrid oldatát 6 csepp/perc sebességgel adagoltuk a keletkező hidrogéngáz kontrollálása végett, a nátrium-ditionit oldatát egyben hozzáöntöttük a vas-oldatokhoz. Az összeöntés után a mintákat 5 (nátrium-borohidrid esetében) illetve 40 percig (nátrium-ditionit esetében) kevertettük, majd a végterméket vízzel és etanollal mostuk. A kapott mintákat frissen felhasználtuk vizsgálatainkhoz. Az így előállított vas nanorészecskéket tartalmazó minták elnevezéseit a 4.1. táblázat foglalja össze.

\section{1. táblázat. A félig-zöld módszerrel előállított vas nanorészecskét tartalmazó szuszpenziók elnevezései}

\begin{tabular}{cl}
\hline Mintaazonosító & \multicolumn{1}{c}{ Összetétel } \\
\hline $\mathrm{nZVI}_{\mathrm{Cl} 2}{ }^{\mathrm{B}}$ & $\mathrm{FeCl}_{2}+\mathrm{NaBH}_{4}$ \\
$\mathrm{nZVI}_{\mathrm{Cl} 2}{ }^{\mathrm{D}}$ & $\mathrm{FeCl}_{2}+\mathrm{Na}_{2} \mathrm{~S}_{2} \mathrm{O}_{4}$ \\
$\mathrm{nZVI}_{\mathrm{Cl}}{ }^{\mathrm{B}}$ & $\mathrm{FeCl}_{3}+\mathrm{NaBH}_{4}$ \\
$\mathrm{nZVI}_{\mathrm{Cl} 3}{ }^{\mathrm{D}}$ & $\mathrm{FeCl}_{3}+\mathrm{Na}_{2} \mathrm{~S}_{2} \mathrm{O}_{4}$ \\
$\mathrm{nZVI}_{\mathrm{S}}{ }^{\mathrm{B}}$ & $\mathrm{FeSO}_{4}+\mathrm{NaBH}_{4}$ \\
$\mathrm{nZVI}_{\mathrm{S}}{ }^{\mathrm{D}}$ & $\mathrm{FeSO}_{4}+\mathrm{Na}_{2} \mathrm{~S}_{2} \mathrm{O}_{4}$ \\
\hline
\end{tabular}

$\mathrm{Az}$ inert atmoszférán előállított nanovas szuszpenziók előállítása során egy gázbevezetéses üvegreaktort használtunk, az oldatok adagolása egy csiszolattal ellátott beöntő nyíláson keresztül történt (4.1. ábra). A szintézis paraméterei megegyeztek a levegőn előállított nanorészecskék szintézisének körülményeivel, kivéve, hogy ezen szintézisek során deoxigenizált ioncserélt vizet használtunk és a reakció nitrogéngáz bevezetése mellett történt. 
A polivinil-pirrolidon (PVP) adagolásának termékmorfológiára és reaktivitásra gyakorolt hatásának vizsgálatához a mintákat az előzőekhez hasonlóan készítettük el deoxigenizált ioncserélt vízzel, inert atmoszférán, a vas mennyiségére nézve 0,3\%-nyi PVP adagolása mellett.

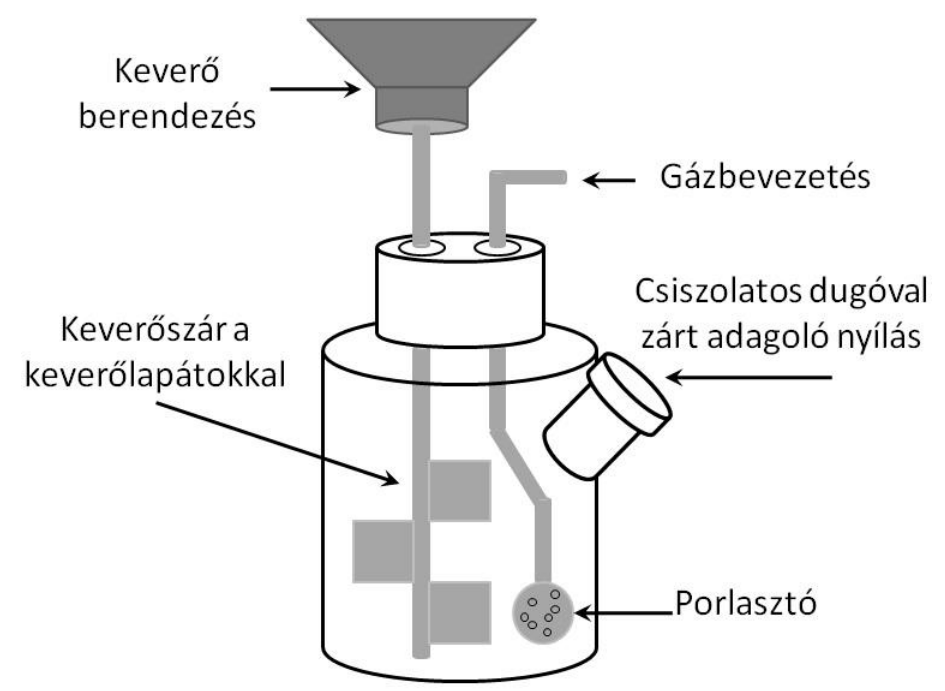

4.1. ábra. A nanovas szuszpenziók előállítására szolgáló reaktor sémája

\subsubsection{Vas nanorészecskék előállítása zöld módszerrel - növényi kivonatok}

A vas nanorészecskéket növényi - kávé, zöld tea és vadszőlő - kivonatok (extraktumok) segítségével is előállítottuk. A vadszőlő kivonatával készült nanorészecskék szintéziséhez a vadszőlő leveleket (Parthenocissus quinquefolia, Virginia creeper) tavasszal, friss hajtás után gyüjtöttük. A levelek felületén lévő esetleges szennyezéseket ioncserélt vizes mosással távolítottuk el, majd a leveleket tömegállandóságig szárítottuk környezeti feltételek mellett. A kivonat elkészítéséhez a megszáradt, porított levelekből 5 g-ot 100 mL ioncserélt vízhez adtunk, majd az így előállított „oldatot” $80^{\circ} \mathrm{C}$-on 80 percig forraltuk, végül visszahűlés után $0,2 \mu \mathrm{m}$ pórusátmérőjü szürőn szürtük, további felhasználásig pedig $4{ }^{\circ} \mathrm{C}$-on tároltuk. Hasonlóan jártunk el a kávé és zöld tea kivonatok elkészítése során is, kivéve, hogy a vásárolt kávé és zöld tea levelek nem igényeltek előzetes tisztító-szárító lépést, és az extraktum előállításához a kávéból 2 g-ot, a zöld tea levelekből 5 g-ot mértünk $100 \mathrm{~mL}$ csapvízhez. A hőkezelés a kávé esetében 5 , a zöld tea esetében 20 percig tartott $80^{\circ} \mathrm{C}$-on.

A vas nanorészecskék szintézise során $0,1 \mathrm{M}$ vas(III)-klorid csapvizes oldatát a megfelelő kivonattal reagáltattuk 1:1 térfogatarányban 24 órán keresztül szobahőmérsékleten. A kapott részecskéket desztillált vízzel és etanollal mostuk, majd a mintákat frissen felhasználtuk vizsgálatainkhoz. A zöld szintézismódszerekkel előállított vas nanorészecskéket tartalmazó minták elnevezését a 4.2. táblázat foglalja össze. 


\section{2. táblázat. Az növényi kivonatokkal előállított vas nanorészecskét tartalmazó} szuszpenziók elnevezései

\begin{tabular}{cl}
\hline Mintaazonosító & \multicolumn{1}{c}{ Összetétel } \\
\hline $\mathrm{nZVI}^{\mathrm{K}}$ & $\mathrm{FeCl}_{3}+$ kávé kivonat \\
$\mathrm{nZVI}^{\mathrm{ZT}}$ & $\mathrm{FeCl}_{3}+$ zöld tea kivonat \\
$\mathrm{nZVI}^{\mathrm{V}}$ & $\mathrm{FeCl}_{3}+$ vadszőlö kivonat \\
\hline
\end{tabular}

\subsubsection{Ezüst nanorészecskék előállítása zöld módszerrel - növényi kivonatok}

Az ezüst nanorészecskék előállításához az előzőekben ismertettet módon készült kávé és zöld tea kivonatát használtuk fel, annyi kivétellel, hogy a kivonatok elkészítéséhez ioncserélt vizet használtunk minden esetben. A szintézis során $0,1 \mathrm{M}$ ezüst-nitrát vizes oldatát a megfelelö kivonattal reagáltattuk 1:1 térfogatarányban 24 órán keresztül szobahőmérsékleten. A kapott részecskéket ioncserélt vízzel mostuk, majd a felhasználásig $4{ }^{\circ} \mathrm{C}$-on tároltuk. A kávé kivonatával redukált mintát C-AgNP-nek, a zöld tea kivonatával előállított ezüst nanorészecskét GT-AgNP-nek neveztük el.

\subsection{Vizsgálati módszerek}

Az előállított vas és ezüst nanorészecskék tulajdonságait számos módszerrel vizsgáltuk. Jellemeztük a részecskék morfológiáját, reaktivitását és szerkezetét. A vas nanorészecskék anaerob mikroba populációra gyakorolt hatását mikrokozmosz modellrendszer segítségével követtük. Az ezüst nanorészecskék biológiai aktivitását különböző antimikrobiális és citotoxicitás tesztekkel vizsgáltuk. A vizsgálatok során minden esetben legalább két (általában 3-5) párhuzamos, egymástól független mérést végeztünk, átlagot és szórást számoltunk, amennyiben nagyobb eltérést észleltünk a mérések vagy kiértékelés közben, megismételtük a minta előállítását és vizsgálatát.

\subsubsection{Transzmissziós elektronmikroszkópia (TEM)}

Az elektron sugárnyalábot használó transzmissziós elektronmikroszkóp szilárd testek szubnanométeres laterális képi felbontású leképezésére alkalmas módszer. A képalkotáshoz a mintán áthaladó nagy energiára felgyorsított elektronokat használjuk. A TEM segítségével tanulmányozhatóak a nanoméretü anyagok, információt nyerhetünk többek között a nanoszerkezetek méretéröl és morfológiai sajátosságaikról.

Az előállított nanorészecskék morfológiáját és méretét FEI TECNAI G2 20 X-Twin, 200 kV-os gyorsítófeszültséggel üzemelő transzmissziós elektronmikroszkóppal vizsgáltuk. A mérésekhez a minták nagy hígítású etanolos szuszpenziójából pár cseppet $3 \mathrm{~mm}$ átmérőjü, 
szénfilmmel bevont rézrostélyra (grid-re) cseppentettünk, majd az adott mintára jellemzö területekről felvételeket készítettünk. A nanorészecskék méretét ImageJ program segítségével határoztuk meg ${ }^{191}$.

\subsubsection{Röntgendiffraktometria (XRD)}

A röntgensugarak diffrakciója a kristályokon a kristály szerkezeti és anyagi minőségére jellemző információt szolgáltat. A módszer alapja a röntgensugár és a kristályrács kölcsönhatása. Röntgensugarakat kristályos anyagon átbocsátva elhajlás és interferencia jelenség lép fel. Az így keletkező interferenciakép egyértelmű információt szolgáltat a kristály szerkezetéről és anyagi minőségéről.

A különböző szintézisek során előállított nanorészecskék anyagi minőségét röntgendiffrakciós módszerrel azonosítottuk. Méréseinket $\mathrm{CuK \alpha}(\lambda=0,154 \mathrm{~nm})$ sugárforrással felszerelt Rigaku Miniflex II készülékkel végeztük $2 \theta=5-80^{\circ}$-os szögtartományban. A mintákat porformában mértük, a kapott diffraktogramokat felhasználva a minták azonosítását JCPDS (Joint Committee on Powder Diffraction Standards) kártyák és irodalmi adatok alapján végeztük el.

\subsubsection{Energiadiszperzív röntgenspektroszkópia (EDS)}

$\mathrm{Az}$ energiadiszperzív röntgenspektroszkópia a minta kémiai összetételéről ad információt az elektrongerjesztéssel kiváltott karakterisztikus röntgensugárzás detektálása és kvantitatív értékelése révén.

Kísérleteinkben ezt a módszert alkalmaztuk a vas nanorészecskék vastartalmának igazolására, illetve az egyes szintézisek során használt csapvízből esetlegesen visszamaradó potenciális szennyeződések kimutatására. Az energiadiszperzív röntgenspektroszkópiás méréseket egy Hitachi S-4700 pásztázó elektronmikroszkópba (SEM) beépített Röntec QX2 spektrométerrel végeztük $20 \mathrm{kV}$ gyorsítófeszültség alkalmazásával.

\subsubsection{Redoxpotenciál (ORP) - redukciós kapacitás}

Redukciós-oxidációs (redox) reakciók legfontosabb paramétere a redoxpotenciál. Egy redoxrendszer redoxpotenciálja az az egyensúlyi elektródpotenciál, amelyet egy inert fémelektród az illető redoxrendszerrel érintkezve felvesz. A redukciós-oxidációs reakció folyamán az egyik anyag (redukálószer) elektront ad le, a másik anyag (oxidálószer) elektront vesz fel: A redoxpotenciál az oxidáló- illetve redukálóképesség mértéke, és mint ilyen, önmagában nem, csak más rendszerek redoxpotenciáljához képest értelmezhető: mindig a 
negatívabb redoxpotenciálú rendszer képes redukálni a pozitívabbat. Általában, minél negatívabb egy redoxpotenciál, annál redukálóbb a rendszer.

A vas nanorészecskék redoxpotenciálját Consort-SK10B vezetőképesség mérő elektróddal felszerelt Consort-C533 típusú multiméter segítségével határoztuk meg a méréseink során.

\subsubsection{Hatékonyság vizsgálat - hidrogéngáz fejlődés}

Az egyes minták nulla vegyértékü vastartalmának meghatározására kénsavas $\left(\mathrm{H}_{2} \mathrm{SO}_{4}\right.$, SigmaAldrich Kft., 95,0-98,0\%) reakciót alkalmaztunk. Az elemi vas a kénsavval az alábbi reakció szerint reagál el (4.5):

$$
\mathrm{Fe}_{(s z)}+\mathrm{H}_{2} \mathrm{SO}_{4(f)}=\mathrm{FeSO}_{4(f)}+\mathrm{H}_{2(g)}
$$

A két anyag reakciója közben keletkező hidrogéngáz mennyiségéből számolni lehet a mintában lévő elemi vas tartalmát. A mérések során az egyes mintákból 100 mL-nyit jól lezárt és előzőleg nitrogéngázzal átöblített gömblombikba öntöttünk (4.2. ábra).

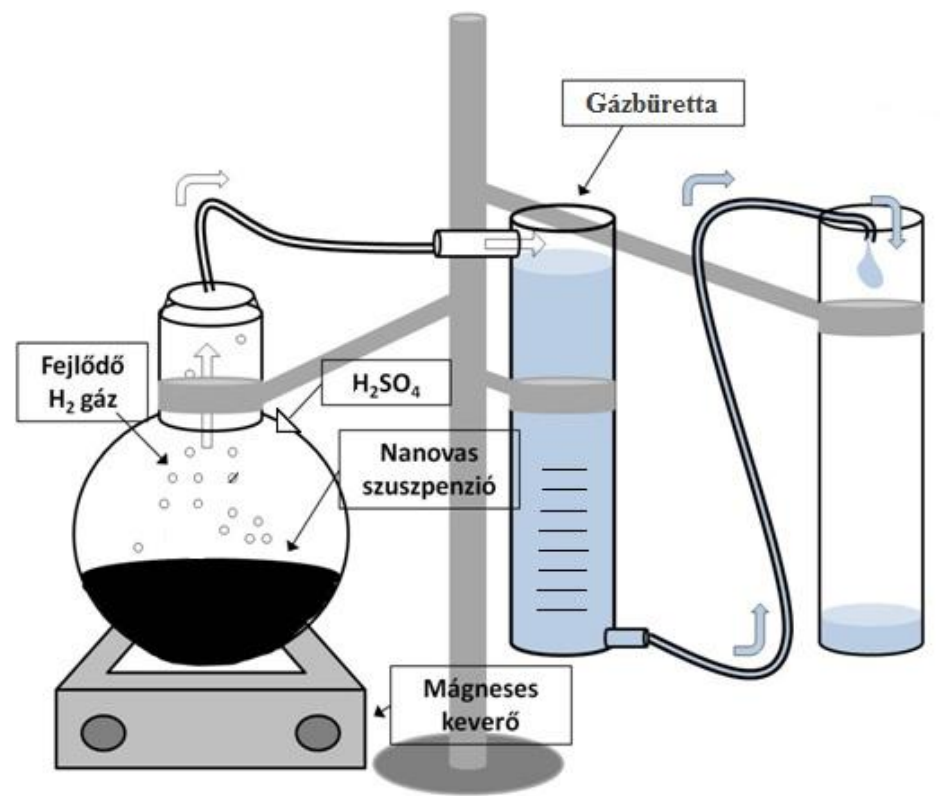

\section{2. ábra. Az egyes nanovas szuszpenziók hatékonyságának vizsgálatára szolgáló rendszer}

A lombik két nyílással rendelkezett: az egyik, szeptummal zárt nyíláson keresztül adagoltuk injekciós tủvel a vas szuszpenziókhoz a kénsavat; a másik nyílást egy gázbürettához kapcsoltuk, így a keletkező hidrogéngáz a bürettában levő vizet kiszorította. A gázbürettában levő folyadék szintje a keletkező gázzal arányosan csökkent. Az egyensúly beállta után leolvastuk a fogyást és meghatároztuk a szuszpenziók elemi vas tartalmát a (4.6) 
képlettel számolva. A 100\%-os hatékonyságnak azt vettük, amikor a rendszerben jelenlévő összes vas (sztöchiometriailag) elreagált a kénsavval, vagyis az összes vas $\mathrm{Fe}^{0}$ állapotúnak tekinthető.

$$
H \%=\frac{n_{F e(\text { mért érték })}}{n_{F e(\text { kalkulaltérték })}} \cdot 100
$$

\subsubsection{Hatékonyság vizsgálat - Illékony klórozott szénhidrogének bontásának vizsgálata}

Az előállított nanovas szuszpenziók degradációs hatékonyságát egy illékony klórozott szénhidrogénnel szennyezett területről származó talajvíz mintában (a mintát egy kármentesítés alatt lévő területről kaptuk) vizsgáltuk. A mérések során a különböző módon előállított vas nanorészecskéket 6 órán keresztül reagáltattuk a szennyezett talajvízzel, majd az egyes minták gázkromatográfiás-tömegspektrometriás vizsgálatát egy akkreditált laborban végezték. A 2500, 5000 és 10000 ppm koncentrációjú nanovas szuszpenziók degradációs hatékonyságát is vizsgáltuk, és az ekvimoláris mennyiségű adagolás mellett, kétszeres és háromszoros felesleg alkalmazásával is végeztünk méréseket.

A lebontó hatást hatékonysággal fejeztük ki, amely fogalom alatt a talajvíz mintában található illékony klórozott szénhidrogének valamilyen mértékü nanovas általi lebontását értjük. A lebontási hatékonyság százalékos értékét a következőképpen számoltuk ki: a 6 óra után jelen lévő illékony klórozott szénhidrogének összkoncentrációját elosztottuk a kiindulási illékony klórozott szénhidrogének összkoncentrációjával; a 100\%-os hatásfok így azt jelenti, amikor a talajvízből az összes illékony klórozott szénhidrogént sikeresen eltávolítjuk.

\subsubsection{Terepi teszt}

A $\mathrm{nZVI}_{\mathrm{S}}{ }^{\mathrm{D}}$ szuszpenzió terepi tesztelése egy nagyméretü remediációs projekt keretén belül valósult meg 2014-2015-ben az Alföld délkeleti részén. A területen azonosított legfőbb szennyezők az illékony klórozott szénhidrogének voltak: perklóretilén (PCE), triklóretilén (TCE), diklóretilén (DCE, cisz- és transz együttesen) és vinil-klorid (VC). A szennyezők kezdeti koncentrációját a talajvízben 2014. 09. 17-én mérték, az első injektálás 2014. 09. 19-én, a második injektálás 2014. 11. 26-án történt. Mindkét injektálás alkalmával több, mint

$500 \mathrm{dm}^{3} 5000$ ppm koncentrációjú $\mathrm{nZVI}_{\mathrm{S}}^{\mathrm{D}}$ szuszpenziót juttattak a talajba -12 méternél, majd rácsszerűen elhelyezett monitoring kutak segítéségével követték a szennyezők összetételének és mennyiségének alakulását egészen 2015. január végéig. A monitoring kutak az injektáló 
ponttól 5 méter távolságra helyezkednek el. A mintákat szilikon csöveken keresztül vették és a teljesen megtöltött üvegedényeket sötétben, $4{ }^{\circ} \mathrm{C}$-on tárolták a vizsgálatok elvégzéséig.

\subsubsection{Induktív csatolású plazma-tömegspektrometria (ICP-MS)}

A nanorészecskék felületéröl felszabaduló ionok koncentrációjának meghatározását induktív csatolású plazma-tömegspektrometriás (ICP-MS) méréssel határozták meg (Agilent Model 7700x). Ennél az emissziós spektroszkópiai módszernél a gerjesztett atomok és ionok előállítása induktív csatolású plazma segítségével történik, amelybe porlasztva bevezetik az analizálandó minta vizes oldatát. Az alkotóelemek elektronokkal és más töltött részecskékkel való ütközései során elektronokat adnak le, illetve vesznek fel. Ennek eredményeként az adott kémiai elemre jellemző hullámhosszúságú elektromágneses sugárzás jön létre. Az emittált sugárzás intenzitásából a mintában előforduló elem koncentrációjára lehet következtetni.

A vas nanorészecskék esetében a mikrokozmoszokból vett minták oldott vas tartalmát határoztuk meg ezzel a módszerrel salétromsavas feltárást követően. A növényi kivonatokkal előállított ezüst nanorészecskékről felszabaduló ionok mennyiségét is ennek a módszernek a segítségével adtuk meg. A nanorészecskéket 17,5 mg/mL-es koncentrációban 10\% borjú szérumot (FBS - Fetal Bovine Serum), 2 mM L-glutamint, 0,01\% sztreptomicint és 0,005\% ampicillint tartalmazó Dulbecco's modified Eagle's médiumban (DMEM) inkubáltuk 24 órán keresztül $37^{\circ} \mathrm{C}$-on, $5 \%$-os $\mathrm{CO}_{2}$-termosztátban, majd centrifugálás (20 perc, $\left.10285 \mathrm{~g}\right)$ után a mintákat salétromsavval feltártuk. A fenti kondíciókat a citotoxicitás mérés körülményeihez hasonlóan állítottuk be.

\subsubsection{Ultraibolya-látható abszorpciós spektrometria (UV-VIS)}

Az ultraibolya (UV, $200 \mathrm{~nm} \leq \lambda \leq 400 \mathrm{~nm}$ ), ill. látható (VIS, $400 \mathrm{~nm} \leq \lambda \leq 800 \mathrm{~nm}$ ) fény elnyelése során megváltozik a molekulák, atomok elektroneloszlása; az elektronok a kisebb energiájú pályákról nagyobb energiájúakra ugranak át, vagyis gerjesztődnek. Egy molekula azon részleteit, amelyekben az elektronátmenetek létrejönnek (azaz elnyelik a fényt), kromoforoknak nevezzük. A fényelnyelés mértéke az abszorbancia (4.7):

$$
A_{\lambda}=\lg \frac{I_{o}}{I}
$$

ahol $\mathrm{A}_{\lambda}$ az adott hullámhosszhoz tartozó abszorbancia, $\mathrm{I}_{0}$ a besugárzott, I pedig a detektált fény intenzitása. Ha az abszorbancia mértékét a besugárzott elektromágneses hullám energiájának (hullámhosszának) függvényében vizsgáljuk, abszorpciós spektrumot kapunk. 
Az abszorpciós színképben megjelenő elnyelési sávok helye minőségi információkat szolgáltat.

Méréseinket Ocean Optics 355 DH-2000-BAL UV-VIS spektrofotométerrel végeztük 350-800 nm hullámhossz között vizes közegben, $1 \mathrm{~cm}$-es kvarcküvettában, szobahőmérsékleten.

\subsubsection{Dinamikus fényszórás (DLS)}

A dinamikus fényszórás (DLS) a részecskék méretének, és a méreteloszlást jellemző polidiszperzitás meghatározására szolgáló módszer. A mérés elve azon alapszik, hogy a fényt szóró részecskék a Brown-mozgás miatt folyamatosan változtatják szóró centrumuk orientációját és helyzetét. Minél kisebb a részecske, annál gyorsabb a mozgása, azaz annál nagyobb a transzlációs diffúziós együttható, melyet a szórt fény fluktuációjának analízisével lehet megállapítani. Az Einstein-Stokes összefüggés értelmében a transzlációs diffúziós együttható és a részecskeméret között fordított arányosság áll fenn ${ }^{192}$.

A nanorészecskék méretét Zetasizer NanoZS (Malvern) (fényforrás: egy $4 \mathrm{~mW}$ teljesítményü, $633 \mathrm{~nm}$ hullámhosszú He-Ne lézer) dinamikus fényszórásmérő berendezés segítségével határoztuk meg.

\subsubsection{Infravörös spektroszkópia (FT-IR)}

Infravörös spektroszkópiás mérés során infravörös hullámhossztartományba eső fénnyel sugározzuk be a mintát, mely a molekulák különböző kvantált rezgéseivel kölcsönhatva bizonyos hullámhosszokon elnyelést szenved. Az elnyelés hullámhossza jellemző az anyagban található kémiai kötésekre, így információt nyerhetünk a mintát felépítő elemekről, a közöttük fennálló kötésekröl, illetve kristályos anyagok esetén a kristályszerkezetben bekövetkező átrendeződésekről.

Méréseinket transzmissziós módban, Bruker Vertex 70 spektrofotométerrel végeztük 450-4000 $\mathrm{cm}^{-1}$ hullámszám tartományban, $4 \mathrm{~cm}^{-1}$-es spektrális felbontás mellett. A mintákat 100 mg KBr-dal összekeverve elporítottuk, majd pasztilláztuk. Referenciaként tiszta $\mathrm{KBr}$ pasztillákat használtunk.

\subsubsection{Mikrokozmosz rendszerek}

A mikrokozmosz vizsgálatokat $100 \mathrm{~mL}$-es steril poli(tetrafluoroetilén) (PTFE) kupakkal zárható üvegben végeztük. A vizsgálatokhoz $75 \mathrm{~mL}$ 3-(N-morfolino)propánszulfonsav (MOPS) pufferelt anaerob tápoldathoz $25 \mathrm{~mL}$ 
$10^{5} \mathrm{db}$ sejt/mL Dehalococcoides, szulfátredukáló és metanogén baktériumokat tartalmazó talajvizet adtunk, melyhez a különböző szintézissel készített nanovasakat $0,1 \mathrm{~g} / \mathrm{L}$ koncentrációban adtuk és a TCE koncentrációt $3 \mathrm{mg} / \mathrm{L}-\mathrm{re}$ állítottuk be.

$\mathrm{Az}$ anaerob tápoldat literenként a következő összetevőket tartalmazta: $1 \mathrm{~g} \mathrm{NaCl}$ (17 mM), 0,41 g MgCl$\times 2 \times 6 \mathrm{H}_{2} \mathrm{O}(2 \mathrm{mM}), 0,27 \mathrm{~g} \mathrm{NH}_{4} \mathrm{Cl}(5 \mathrm{mM}), 0,52 \mathrm{~g} \mathrm{KCl}(7 \mathrm{mM}), 0,15 \mathrm{~g}$ $\mathrm{CaCl}_{2} \times 2 \mathrm{H}_{2} \mathrm{O}(1 \mathrm{mM}), 0,2 \mathrm{~g} \mathrm{K \textrm {KH } _ { 2 }} \mathrm{PO}_{4}(1,5 \mathrm{mM}), 0,25 \mathrm{mg}$ resazurin $(1 \mathrm{mM}), 0,41 \mathrm{~g}$ nátrium acetát $(5 \mathrm{mM}), 1 \mathrm{~mL}$ mikroelem oldat $(1000 \times$ törzsoldat $)$ és $1 \mathrm{~mL}$ szelenit-wolframát oldat $(1000 \times \text { törzsoldat })^{193}$. A tápoldatot forralás után nitrogén atmoszférában hütöttük és $0,084 \mathrm{~g}$ $\mathrm{NaHCO}_{3} \quad(1 \mathrm{mM}), \quad 0,048 \mathrm{~g} \quad \mathrm{Na}_{2} \mathrm{~S} \times 9 \mathrm{H}_{2} \mathrm{O} \quad(0,2 \mathrm{mM})$ és $0,031 \mathrm{~g}$ L-ciszteinnel $(0,2 \mathrm{mM})$ egészítettük ki. Ezt követően $121{ }^{\circ} \mathrm{C}$-on 30 percig strerilizáltuk majd szüréssel sterilezett $20 \mathrm{mM}$ MOPS pufferrel (1 M törzsoldat, $\mathrm{pH} 7,4), 0,5 \mathrm{mM}$ titánium(III)nitrilotriacetáttal (25 mM törzsoldat) és vitamin oldattal egészítettük $\mathrm{ki}^{194}$.

A kísérletek során, az előbbiekben leírt módon összeállított batch rendszereket anaerob körülmények között, $20^{\circ} \mathrm{C}$-on, sötétben inkubáltuk. A mikrobiális összetétel változásának követéséhez 4, 10 és 20 nap inkubációt követően mintát vettünk az anaerob élősejtszám mérésekhez és molekuláris biológiai vizsgálatokhoz. Ezzel párhuzamosan háromszor $2 \mathrm{~mL}$ mintát elküldtünk kémiai vizsgálatra (illékony klórozott alifás szénhidrogén összetétel változás és lebontás során keletkező köztitermékek nyomon követése).

\subsubsection{Anaerob heterotróf élő sejtszám}

A mikrokozmoszokból vett mintából 5 tagú 10-es léptékü hígítási sort készítettünk, majd 100-100 $\mu \mathrm{L}$ hígított mintát R2A táptalajra szélesztettünk. Az R2A táptalaj összetétele: 0,5 g élesztőkivonat; $0,5 \mathrm{~g}$ proteózpepton; $0,5 \mathrm{~g}$ kazein hidrolizátum; $0,5 \mathrm{~g}$ glükóz; $0,5 \mathrm{~g}$ keményítő; $0,3 \mathrm{~g} \mathrm{~K} \mathrm{~K}_{2} \mathrm{HPO}_{4} ; 0,05 \mathrm{~g} \mathrm{MgSO}_{4} \times 7 \mathrm{H}_{2} \mathrm{O} ; 0,3 \mathrm{~g}$ nátrium-piruvát; $15 \mathrm{~g}$ agar; $1 \mathrm{~L}$ desztillált víz, pH 7,2 $\pm 0,2$. A táptalajra szélesztett mintákat anaerob körülmények között, $20^{\circ} \mathrm{C}$-on, sötétben inkubáltuk 2 napig. Az inkubációt követően a táptalajon képződött kolóniákat megszámoltuk és a hígítással korrigált sejtszám értékeket átlagoltuk.

\subsubsection{DNS preparálás}

A kiindulási DNS vizsgálatához $15 \mathrm{~mL}$ talajvizet 7068 g-n 30 percig $25^{\circ} \mathrm{C}$-on összecentrifugáltunk, majd a kapott üledékből MoBio PowerSoil ${ }^{\circledR}$ DNA Isolation Kittel (MoBio Laboratories, Carlsbad, CA) DNS-t izoláltunk a gyártó utasítása szerint. A DNS mennyiségét Qubit 2.0 Fluorimeterrel (Invitrogen, Carlsbad, CA) mértük a gyártó utasításai szerint és agaróz gélelektroforézissel (1\% agaróz koncentráció, 1 kb DNA Ladder marker 
(GeneRuler) mellett 130 V-on 30 percig) ellenőriztük a DNS izolálás sikerességét. A PCR reakciók elvégzéséig minden DNS mintát $-20{ }^{\circ} \mathrm{C}$-on tároltunk.

\subsubsection{Polimeráz láncreakció (PCR) és denaturáló gradiens gélelektroforézis (DGGE)}

A preparált genomiális DNS-mintákból a $16 \mathrm{~S}$ riboszómális RNS kódoló gént (16S rDNS) eubaktérium specifikus primerekkel (EubB

5'-AGAGTTTGATCMTGGCTCAG-3' és EubA

5'-AAGGAGGTGATCCANCCRCA-3') PCR - reakció segítségével amplifikáltuk ${ }^{195}$.

A denaturáló gradiens gélelektroforézishez (DGGE) szükséges „GC-clamp”-pel rendelkező és kb. 200 bp hosszúságú PCR termékeket DGGE PCR-reakcióval állítottuk elő, ahol a 16S rDNS PCR termékek szolgáltak templátként. A 16S rRNS gén V3 régiójának amplifikálásához a 16R 5'-ATTACCGCGGCTGCTGG-3' és a 16GC 5'-CGCCCGCCGCGCGCGGCGGGCGGGGCGGGGGCACGGGGGGCCTACGGG AGGCAGCAG-3' primereket alkalmaztuk ${ }^{196}$. A reakciók során KOD (Thermococcus kodakaraensis, Novagen) polimerázt használtunk a gyártó utasítása szerint. Minden kísérletben alkalmaztunk pozitív és negatív kontrollreakciókat. A 16S PCR reakciókat $30 \mu \mathrm{L}$, a DGGE PCR reakciókat $50 \mu \mathrm{L}$ végtérfogatban mértük össze, az amplifikálást PTC 200 Thermalcycler (MJ Research) készülékben végeztük az alábbi beállításokkal (4.3. táblázat):

\section{3. táblázat A PCR amplifikációk körülményei}

\begin{tabular}{lclc}
\hline & Hőmérséklet & \multicolumn{1}{c}{ Idő } & Ciklusszám \\
\hline Elödenaturáció & $95^{\circ} \mathrm{C}$ & 2 perc & 1 \\
$\begin{array}{l}\text { Denaturáció } \\
\text { Hibridizáció }\end{array}$ & $95^{\circ} \mathrm{C}$ & 20 másodperc & \\
(annealing) & $55^{\circ} \mathrm{C}$ & 10 másodperc & 30 \\
Extenzió & $70^{\circ} \mathrm{C}$ & $40 / 10$ másodperc* & \\
Végső extenzió & $70^{\circ} \mathrm{C}$ & 5 perc & 1 \\
\hline
\end{tabular}

*extenzió ideje a 16S rRNS gén amplifikálásakor 40 másodperc, a V3 régió amplifikálásakor 10 másodperc volt

A denaturáló gradiens gélelektroforézist előzetes kísérleteink alapján 40-60\%-os denaturáló gradiens koncentráció mellett ${ }^{1}$, 8\%-os poliakrilamid gélen (37:1 akrilamid (SigmaAldrich Kft.) - biszakrilamid (Sigma-Aldrich Kft.) keverék 1x TAE pufferben) végeztük. A denaturáló ágens urea (Sigma-Aldrich Kft.) és formamid (Molar Chemicals Kft.) volt.

\footnotetext{
${ }^{1}$ A $0 \%$-os koncentrációjú denaturáló oldat nem tartalmaz sem ureát, sem formamidot, a 100 ml 100\%-os koncentrációjú denaturáló oldat definíció szerint $40 \mathrm{ml}$ formamidot és $42 \mathrm{~g}$ ureát tartalmaz.
} 
Közvetlenül a gélöntés előtt $16 \mathrm{~mL}$ denaturáló oldathoz 6,5 $\mu \mathrm{L}$ TEMED-et $(\mathrm{N}, \mathrm{N}, \mathrm{N}$ ',N'tetrametil-etiléndiamin, Serva Electrophoresis Kft.) és $160 \mu \mathrm{L} \quad 10 \%$-os APS-t (ammónium-perszulfát, AnalaR Normapur ${ }^{\circledR}$ Kft.) adva, 16x16 cm-es, 16 zsebes gélt öntöttünk a Bio-Rad gélöntő rendszer segítségével a gyártó utasítása szerint. $50 \mu \mathrm{L}$ DGGE PCR termékhez $10 \mu \mathrm{L}$ 6x DNA Gel Loading Solution (Quality Biological Inc.) festéket kevertünk. A futtatáshoz minden mintából $25 \mu \mathrm{L}$-t vittünk fel a gélre. A DGGE futtatást Bio-Rad DCode Universal Mutation Detection System készülékben $60^{\circ} \mathrm{C}$-on, 150V-on, 1x TAE pufferben 4 órán át végeztük. Az elektroforézis után a gélt 20 percig etídium-bromiddal $(0,5 \mu \mathrm{g} / \mathrm{mL} 1 \mathrm{x}$ TAE pufferben) festettük, majd UV fény alatt vizsgáltuk és VisionWorks ${ }^{\circledR}$ LS 5.5.0 szoftverrel dokumentáltuk.

Az egyes mintázatokról képzett hasonlósági mátrix alapján hierarchikus osztályozást végeztünk. A hierarchikus osztályozás a TotalLab Phoretics 1D Pro programmal és a távolság-optimalizáló UPGMA csoportátlag módszerrel (Unweighted Pair Group Method of Average - súlyozás nélküli pár csoport módszer számtani átlag) történt ${ }^{197}$. A kapott eredményeket dendrogramon ábrázoltuk. A függőleges tengelyen a minták azonosítóját, vízszintesen pedig az osztályok összevonásának szintjeit, a távolságmértékeket (hasonlósági mértékek) tüntettük fel.

\subsubsection{Kvantitatív polimeráz láncreakció (qPCR)}

A kvantitatív polimeráz reakciók (qPCR) során a reduktív deklorinációért felelős Dehalococcoides baktériumokra jellemző gének (16S rRNS gén, vinil-klorid reduktív deklorinálásáért felelős vcrA gén, triklóretén reduktív deklorinálásáért felelős tceA gén), a szulfátredukáló baktériumokra jellemző gének (adenozin-5'-foszfoszulfát (APS) reduktáz (apsA) és a disszimilatórikus szulfit-reduktáz (dsrA) gének) valamint a metanogén archebaktériumokra jellemző $m c r A$ (metil-koenzim-M reduktáz) gén mennyiségét vizsgáltuk.

A qPCR reakciók során a relatív kvantifikálás módszerét alkalmaztuk, azaz a gének százalékos mennyiségét határoztuk meg a minták összes eubaktérium mennyiségéhez viszonyítva.

A reakciók során Taq (Thermus aquaticus, Fermentas) polimerázt használtunk a gyártó utasítása szerint. A génspecifikus qPCR reakciókat $20 \mu \mathrm{L}$ végtérfogatban mértük össze, az amplifikálást egy Lightcycler ${ }^{\circledR} 96$ (Roche Life Sciences) készülékben végeztük, a reakcióelegy összetételét a 4.4. táblázat, az alkalmazott primerek szekvenciáját pedig a 4.5. táblázat mutatja. A primer hibridizáció (annealing) minden esetben $60^{\circ} \mathrm{C}$-on történt. 


\section{4. táblázat. A génspecifikus primerekkel végzett PCR reakcióelegyek összetétele}

\begin{tabular}{lc}
\hline \multicolumn{1}{c}{ Roche (LighCycler 96) } & $\boldsymbol{\mu L}$ \\
\hline steril víz & 7 \\
$2 \times$ Greenmaster Mix & 10 \\
forward primer $10 \mu \mathrm{M}$ & 1 \\
reverz primer $10 \mu \mathrm{M}$ & 1 \\
templát DNS $(10 \mathrm{ng})$ & 1 \\
\hline Össztérfogat & 20
\end{tabular}

4.5. táblázat. A qPCR mérés során alkalmazott primerek és adataik

\begin{tabular}{|c|c|c|c|}
\hline Primer & Célgén & Szekvencia $\left(5^{\prime} \rightarrow 3^{\prime}\right)$ & Hivatkozás \\
\hline $\begin{array}{l}1327 \mathrm{~F} \\
1420 \mathrm{R}\end{array}$ & eubaktérium & $\begin{array}{l}\text { CCA TGA AGT CGG AAT CGC TAG } \\
\text { ACT CCC ATG GTG TGA CGG }\end{array}$ & $\begin{array}{l}\text { Corless } \\
(2000)^{198}\end{array}$ \\
\hline $\begin{array}{l}\text { mlas } \\
\text { FmcrA-rev }\end{array}$ & $\begin{array}{l}\text { metanogén } \\
\text { archebaktérium } \\
\text { mcrA }\end{array}$ & $\begin{array}{l}\text { GGT GGT GTM GGD TTC ACM CAR TAC } \\
\text { GTT CAT BGC GTA GTT VGG RTA GT }\end{array}$ & $\begin{array}{l}\text { Steinberg } \\
\text { és Regan } \\
(2008)^{199} \\
\end{array}$ \\
\hline RH1-dsr-F & szulfát- & GCC GTT ACT GTG ACC AGC C & \multirow{4}{*}{$\begin{array}{l}\text { Ben-Dov } \\
(2007)^{200}\end{array}$} \\
\hline RH3-dsr-R & & GGG TGG AGC CGT GCA TGT T & \\
\hline RH1-aps-F & $\begin{array}{l}\text { bakterium } \\
d s r \mathrm{~A}\end{array}$ & CGC GAA GAC CTK ATC TTC GAC & \\
\hline RH2-aps-R & apsA & ATC ATG ATC TGC CAG CGG CCG GA & \\
\hline ver1022F & $\begin{array}{l}\text { reduktív } \\
\text { dehalogenáz }\end{array}$ & CGG GCG GAT GCA CTA TTT T & \multirow{4}{*}{$\begin{array}{l}\text { Ritalahti } \\
(2006)^{201}\end{array}$} \\
\hline vcr1093R & $v c r A$ & GAA TAG TCC GTG CCC TTC CTC & \\
\hline tce $1270 \mathrm{~F}$ & $\begin{array}{l}\text { reduktív } \\
\text { dehalogenáz }\end{array}$ & ATC CAG ATT ATG ACC CTG GTG AA & \\
\hline tce1336R & tce A & GCG GCA TAT ATT AGG GCA TCT T & \\
\hline
\end{tabular}

A qPCR kalibrálásához Desulfovibrio desulfuricans DSM642T és Methanosarcina barkeri Schnellen 1947 (DSM 804) referencia törzseket, valamint Dehalococcoides 16S rRNS gént és vcrA, tceA gént tartalmazó plazmid DNS-t alkalmaztunk.

A qPCR módszer kalibrálásához először egy relatív kvantifikációt adó kalibrációs görbe felvételére volt szükségünk. A relatív kvantifikáció esetén nem a minta tényleges szulfátredukáló baktérium tartalmát adjuk meg, hanem a szulfátredukáló baktériumok genomi DNS-ének arányát az összes tisztított bakteriális eredetű DNS-hez képest. Ehhez kétféle PCR reakcióra volt szükség, az egyiket a specifikus, a másikat univerzális oligonukleotidokkal mértük össze. A normál PCR-ben amplifikált termékeket kitisztítottuk, majd a mennyiségi

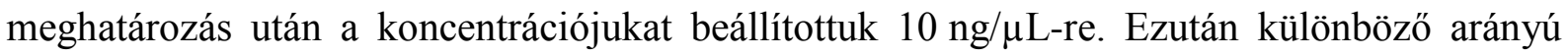


keverékeket állítottunk elő a specifikus és univerzális primerekkel kapott termékekből: 1:1, 1:10, 1:100, 1:1000, 1:10000 arányokban. Ezeken a keverékeken lefuttatva a kvantitatív PCR-t, a $\triangle \mathrm{CT}$ értékeket kiszámítva felvehető volt egy kalibrációs egyenes, amely ábrázolja a keverési arányt a $\Delta \mathrm{CT}$ függvényében. A mért $\mathrm{CT}$ értékek és az eubaktérium specifikus primerekkel kapott $\mathrm{CT}_{16 \mathrm{~S}}$ értékekből számított $\Delta \mathrm{CT}$ értékekkel az alábbi összefüggés (4.8) alapján határoztuk meg a kalibráló függvényt ${ }^{202}$.

$$
\triangle \mathrm{MCT}=\left(C_{T(\text { célgén) }}-C_{T(16 \mathrm{~S})}\right)_{\text {vizsgáltminta }}-\left(C_{T(\text { célgén })}-C_{T(16 \mathrm{~S})}\right)_{\text {kontroll }}
$$

\subsubsection{Sejt proliferációs és citotoxicitás vizsgálatok}

\subsubsection{Sejtkultúrák}

A humán HeLa (humán méhnyakrák epitélsejt, ATCC) sejteket $10 \%$ borjú szérummal (FBS: Fetal Bovine Serum), 2 mM L-glutaminnal, 0,01\%-os sztreptomicinnel és 0,005\%-os ampicillinnel kiegészített, $1 \mathrm{~g} / \mathrm{L}$-es DMEM-ben (Dulbecco's Modified Eagle's Medium, Sigma-Aldrich Kft.) tartottuk fenn. A NIH/3T3 egér fibroblaszt sejteket (ATCC) 10\% FBS, $2 \mathrm{mM}$ L-glutamin, 0,01\%-os sztreptomicin, 0,005\% ampicillin tartalmú 4,5 g/L-es koncentrációjú DMEM médiumban tenyésztettük. A sejtkultúrákat $37^{\circ} \mathrm{C}$-on, állandó parciális nyomású $\mathrm{CO}_{2}$ atmoszféra ( $5 \%$ ) és $95 \%$-os páratartalom mellett tenyésztettük.

\subsubsection{Sejtproliferációs vizsgálat}

Az MTT teszt a sejtek életképességének (viabilitásának) illetve proliferációjának vizsgálatára szolgáló módszer. A kísérletek során HeLa és NIH/3T3 sejtek mitokondriális aktivitását mértük. A HeLa és NIH/3T3 sejteket rendre 5000 sejt/lyuk és 2000 sejt/lyuk koncentrációban 96-lyukú tenyésztőedényben 24 órán keresztül növesztettük, majd különbözö koncentrációjú nanoezüst oldatokkal kezeltük 24 órán keresztül. A kezelés végén foszfátpuffer oldatos (PBS) mosás után a proliferációra gyakorolt hatást MTT-esszé segítségével elemeztük ki. Ennek során a tenyésztőedényekben lévő tápfolyadékokhoz 0,5 mg/mL-es 3-(4,5-Dimetiltiazol-2-il)-2,5-difeniltetrazolium bromid (MTT, Sigma-Aldrich Kft.) oldatot adtunk. Egy órás $37^{\circ} \mathrm{C}$-on történő inkubációt követően az élő sejtek mitokondriumaiban található enzimek a sárga színü MTT-t lila színü formazánná redukálják. A keletkezett formazán kristályokat feloldottuk dimetil-szulfoxid (DMSO) oldatban és spektrofotométer (Synergy HTX, BioTek, Winooski, US) segítségével mértük az egyes lyukakban az $540 \mathrm{~nm}$ hullámhosszon mutatott abszorbanciát, amely arányos az adott 
lyukban levő élő sejtek számával. Az így kapott eredményeket a kezeletlen minták (kontrollok) abszorbancia értékeihez viszonyítva százalékosan fejeztük ki és az AgNP koncentráció függvényében ábrázoltuk.

\subsubsection{Citotoxicitás vizsgálat}

A zöld úton elöállított ezüst nanorészecskék citotoxikus hatását kristályibolya festéssel határoztuk meg. A sejteket 24-lyukú szövettenyésztő lemezen növesztettük. A konfluencia elérése után, a sejteket különböző koncentrációjú ezüst nanorészecskékkel kezeltük 24 óráig. A kezelés után a sejteket háromszor mostuk PBS oldattal, majd 70:30 arányú etanol:aceton keverékkel fixáltuk. A fixált sejteket 0,5\%-os kristályibolya oldattal festettük, majd desztillált vízzel mostuk és levegőn megszárítottuk. A lemezeket lefényképeztük majd a kristályibolyát $400 \mu \mathrm{L} 10 \%$-os ecetsavval feloldottuk. Minden lyukból $100 \mu \mathrm{L}$ oldatot átvittünk egy 96-lyukú lemezre, majd az abszorbanciát 590 nm-es hullámhosszon fotometriásan (Synergy HTX spektrofotométer) detektáltuk.

\subsubsection{Antimikrobiális vizsgálatok}

\subsubsection{Vizsgált törzsek}

Escherichia coli SZMC 0582

Pseudomonas aeruginosa SZMC 0568

Micrococcus luteus SZMC 0264

Bacillus cereus var. mycoides SZMC 0042

Cryptococcus neoformans IFM 5844

Candida albicans ATCC 10231

Candida parapsilosis CBS 604

Saccharomyces cerevisiae SZMC 20733

\subsubsection{Agar-diffúziós módszer}

Az ezüst nanorészecskék antimikrobiális aktivitását agar-diffúziós módszerrel vizsgáltuk baktérium és élesztőgomba törzseken. Az élesztőgombák tenyésztéséhez YPD ( $1 \%$ pepton, $1 \%$ glükóz, $0,5 \%$ élesztőkivonat és $2 \%$ agar), a baktériumok tenyésztéséhez pedig húskivonat-pepton $(0,1 \%$ húskivonat, $0,5 \%$ pepton, $1 \%$ glükóz, $0,2 \%$ élesztőkivonat és $2 \%$ agar) táptalajt használtunk. A mikroba tenyészetekből steril desztillált vízben szuszpenziót 
készítettünk (1 kacsnyi tenyészet/5 mL desztillált víz). A táptalaj felszínre masszív oltással vittük fel a szuszpenziókat.

A $\quad 17,5 \mathrm{mg} / \mathrm{mL}$ koncentrációjú ezüst nanorészecske szuszpenziókból $5 \mu \mathrm{L}-\mathrm{t}$ pipettáztunk a mikrobákkal leoltott táptalaj felszínre. A tenyészeteket $30{ }^{\circ} \mathrm{C}$-on 24 órán át inkubáltuk. Az inkubációs idő elteltével meghatároztuk a gátlási zónák méretét.

\subsubsection{3. É Élőcsíraszám meghatározásos módszer}

Az ezüstrészecskék mikroba sejtekre gyakorolt toxikus hatását a telepképző egységek (colony forming unit, CFU) számának változásával vizsgáltuk Cr. neoformans IFM 5844 és E. coli SZMC 0582 törzsek esetében. Cr. neoformans tenyészetből $4 \times 10^{6} \mathrm{sejt} / \mathrm{mL}$, míg E. coli tenyészetből $2 \times 10^{7}$ sejt/mL koncentrációjú szuszpenziót készítettünk. A szuszpenziókat 17,5; 70; 175; 350 and $1750 \mu \mathrm{g} / \mathrm{mL}$ koncentrációjú C-AgNP illetve GT-AgNP oldattal kezeltük 24 órán keresztül. Az inkubációs idő végén a sejteket centrifugálással kiülepítettük az oldatból (5 perc, 1900 g), majd steril vizes mosás után $1 \mathrm{~mL}$ desztillált vízben szuszpendáltuk fel őket. Négy lépcsőben tízszeres léptékü hígítási sorozatot készítettünk, majd a hígítási sorozat minden egyes tagjából $25 \mu \mathrm{L}-\mathrm{t}$ szélesztettünk YPD vagy húskivonat-pepton táptalaj felszínére, 3 párhuzamos kísérletben. A tenyészeteket $30^{\circ} \mathrm{C}$-on 48 órán keresztül inkubáltuk, majd meghatároztuk a telepképző egységek számát.

Minden kísérletet 3 párhuzamosban 3 alkalommal végeztünk el. 


\section{EREDMÉNYEK ÉS ÉRTÉKELÉSÜK}

\subsection{Nulla vegyértékü vas nanorészecskék környezetbarát előállítása és remediációban való alkalmazhatóságának vizsgálata}

A környezetbarát eljárások kidolgozásánál, a hatékonyságot fenntartva, a költségek optimalizálása a szintézis paramétereinek változtatásával, pl. a felhasznált vegyszerek mennyiségének csökkentésével, a veszélyes anyagok „zöldebb” helyettesítésével, vagy a szintézis energiaigényének csökkentésével érhető el.

A vas nanorészecskék szintézise általában kémiai redukciós úton történik, mivel az eljárás gyors, egyszerü és nem igényel bonyolult vagy költséges felszerelést ${ }^{115}$. Ezáltal a sikeres szintézismódszerek kiterjesztése könnyebben megoldható ipari méretekben is. Az irodalmi áttekintésben bemutatott hátrányai miatt a nátrium-borohidridet redukálószerként alkalmazó módszerekben szükségessé vált egyéb, költséghatékonyabb, környezetbarát, helyettesítő redukálószerek felkutatása és alkalmazása.

A szakirodalom áttekintése után, a nátrium-ditionitot és a különböző növényi kivonatokat (kávé, tea, vadszőlö) találtuk a legmegfelelőbb jelölteknek. Mindegyik kiválasztott redukálószer megfelelt a következő, elsőre kissé ellentmondásos szempontoknak: hatékonyság, gazdaságosság és a további környezeti terhelés minimalizálása.

A következőkben részletesen bemutatjuk, hogy a különböző vas-prekurzorok és redukálószerek felhasználásával, kezeletlen csapvíz alkalmazásával szobahőmérsékleten, levegőn előállított vas nanorészecskéket tartalmazó szuszpenziók (nanovas szuszpenziók) milyen tulajdonsággal rendelkeztek. Továbbá próbáljuk megválaszolni azt a kérdést, hogy a vas nanorészecskék szintézise során a nátrium-ditionit és a különböző növényi extraktumok valós alternatívái lehetnek-e a nátrium-borohidridnek, illetve, hogy az előállított szuszpenziók közül melyek alkalmazhatók sikeresen klórozott szénhidrogénekkel szennyezett talajvíz in situ környezeti kármentesítésében.

\subsubsection{Kémiai redukcióval előállított nulla vegyértékủ vas nanorészecskék jellemzése}

Minden reakció eredményeként a nulla vegyértékü elemi vasra jellemző fényes, sötét fekete színű szuszpenziókat kaptunk. A kapott nanorészecskéket a szintézist követően különböző módszerekkel jellemeztük, ezek eredményeit a következőkben mutatjuk be. 


\subsubsection{Transzmissziós elektronmikroszkópia - morfológia és méret}

Az 5.1. ábra az ún. zöld és félig-zöld módszerekkel előállított vas nanorészecskék egy-egy jellemző TEM felvételét mutatja. Mind a kilenc minta izotróp (irány szerint egyenlő, a tér mindhárom irányába hasonló szimmetriájú térrácsok) morfológiát mutatott. A TEM képek alapján 7 mintánál, a $\mathrm{nZVI}_{\mathrm{Cl} 2}{ }^{\mathrm{D}}$, a $\mathrm{nZVI}_{\mathrm{Cl} 2}{ }^{\mathrm{B}}$, a $\mathrm{nZVI}_{\mathrm{Cl}}{ }^{\mathrm{D}}$, a $\mathrm{nZVI}_{\mathrm{S}}{ }^{\mathrm{B}}$ minták esetében és mindhárom növényi kivonattal elöállított vas minta esetében $\left(\mathrm{nZVI}^{\mathrm{K}}, \mathrm{nZVI}^{\mathrm{ZT}}\right.$ és $\left.\mathrm{nZVI}^{\mathrm{V}}\right)$, a szintézis során egységes méretü és kerekded, gömbszerü nanorészecskék alakultak ki. A $\mathrm{nZVI}_{\mathrm{Cl} 3}{ }^{\mathrm{B}}$ és $\mathrm{nZVI}_{\mathrm{S}}{ }^{\mathrm{D}}$ minták részecskéi jellemzően szögletesebbek voltak, éles sarkokkal és háromszöghöz közelítő alakkal rendelkeztek.

A nanorészecskék átlagos átmérőjének meghatározásához az ImageJ szoftvert használtuk $^{191}$. Jól látható, hogy a növényi kivonatokkal készült vas nanorészecskék közül kettő, a kávé és a zöld tea kivonattal redukált vas nanorészecskék (a nZVI ${ }^{\mathrm{K}}$ és a nZVI ${ }^{\mathrm{ZT}}$ minták) elektronmikroszkópos képe nagyon hasonlónak adódott. Megfigyeltük, hogy a nanorészecskék könnyen aggregátumokat képeztek mindkét esetben. Ezen nanorészecskék TEM képek alapján mért átlagos részecskemérete rendre 124,2 $\pm 31,8 \mathrm{~nm}$ és $119,6 \pm 25,8 \mathrm{~nm}$ volt. A további hét nanovas minta mindegyikében $100 \mathrm{~nm}$ alatt volt a mért átlagos részecskeméret - $\mathrm{nZVI}^{\mathrm{V}}, \mathrm{nZVI}_{\mathrm{Cl} 2}{ }^{\mathrm{B}}, \mathrm{nZVI}_{\mathrm{Cl} 2}{ }^{\mathrm{D}}, \mathrm{nZVI}_{\mathrm{Cl} 3}{ }^{\mathrm{B}}, \mathrm{nZVI}_{\mathrm{Cl}}{ }^{\mathrm{D}}, \mathrm{nZVI}_{\mathrm{S}}{ }^{\mathrm{B}}, \mathrm{nZVI}_{\mathrm{S}}{ }^{\mathrm{D}}-\mathrm{a}$ részecskék átlagos átméröje rendre $47,5 \pm 8,8 ; 23,5 \pm 4,1 ; 70,9 \pm 7,0 ; 25,2 \pm 3,5 ; 25,7 \pm 4,3$; $36,1 \pm 5,2$ és $19,7 \pm 2,2 \mathrm{~nm}$ volt. A TEM felvételek alapján egyik mintában sem figyeltünk meg szennyeződést.

Fontos megjegyeznünk, hogy mivel a szintézisek során kezeletlen csapvizet használtunk, elméletben lehetséges, hogy az előállított nanorészecskék kétfémes (ún. bimetál) részecskék lesznek, melyek vasból és egy redukált, a kezeletlen csapvízben szennyeződésként jelenlévő második fémből állnak. Azonban a magyarországi ivóvizek megengedett fémion tartalmának határértéke szigorúan korlátozott, köszönhetően a merev jogi szabályozásnak 201/2001 (X.25) számú Kormányrendelet az ivóvíz minőségi követelményeiről és az ellenőrzés rendjéröl ${ }^{203}$. A helyhatósági, városi vízművek folyamatos monitorozó tevékenységének köszönhetően a csongrádi régióban a víz különösen jó minőségűnek számít. 

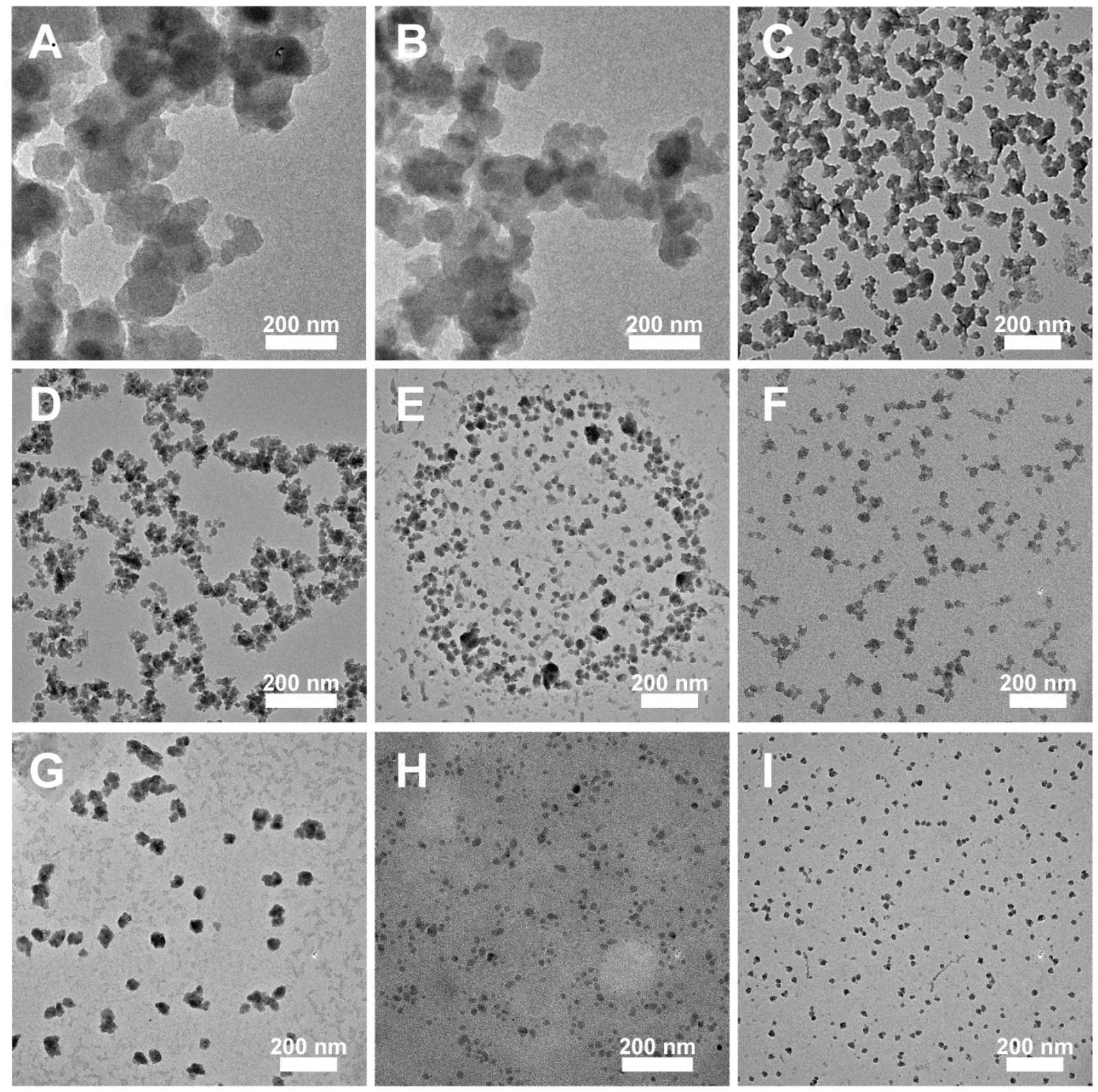

5.1. ábra. Az előállított vas nanorészecskék jellemző TEM felvételei. Az első sorban a növényi kivonatokkal elöállított $\mathrm{nZVI}^{\mathrm{ZT}}(\mathrm{A}), \mathrm{nZVI}^{\mathrm{K}}(\mathrm{B}), \mathrm{nZVI}^{\mathrm{V}}(\mathrm{C})$ minták; a második sorban a nátrium-borohidriddel előállított $\mathrm{nZVI}_{\mathrm{Cl} 2}{ }^{\mathrm{B}}(\mathrm{D}), \mathrm{nZVI}_{\mathrm{Cl} 3}{ }^{\mathrm{B}}(\mathrm{E}), \mathrm{nZVI}_{\mathrm{S}}{ }^{\mathrm{B}}(\mathrm{F})$ minták; a harmadik sorban a nátrium-ditionittal előállított $\mathrm{nZVI}_{\mathrm{Cl} 2}{ }^{\mathrm{D}}(\mathrm{G}), \mathrm{nZVI}_{\mathrm{Cl} 3}{ }^{\mathrm{D}}(\mathrm{H}), \mathrm{nZVI}_{\mathrm{S}}{ }^{\mathrm{D}}(\mathrm{I})$ minták láthatók.

A vártnak megfelelően, az energiadiszperzív röntgenspektroszkópiás (EDS) méréseink során sem tudtunk azonosítani a vason kívül más fémet az előállított mintáinkban (az 5.2. ábra egy nulla vegyértékü vas nanorészecskére jellemző EDS röntgenspektrumot mutat), ami szintén igazolja a csapvízben található fémes jellegü szennyezés alacsony koncentrációját (az általunk használt spektrométer 1 atom\%-os kimutatási határral rendelkezik). 


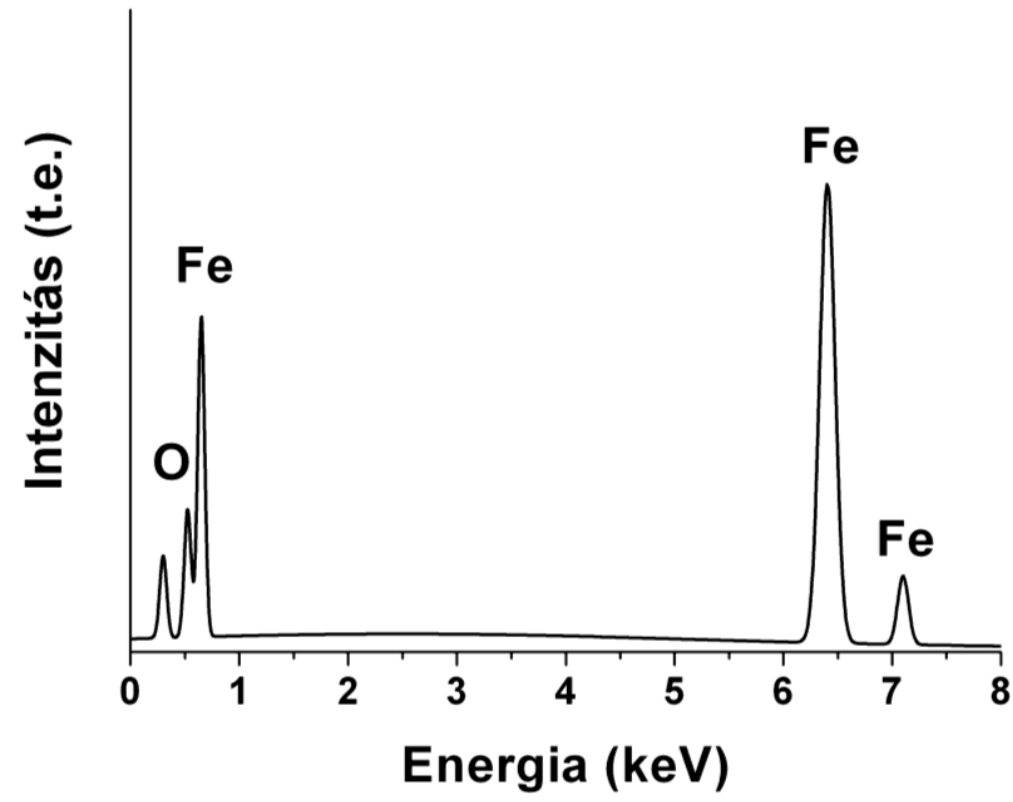

\section{2. ábra. Nulla vegyértékű vas nanorészecskére jellemző energiadiszperzív röntgenspektrum}

Tehát bár feltételezhetjük, hogy a vas nanorészecskék szintézise során kétfémes részecskék is formálódhatnak a kiindulási vasvegyületböl és a kezeletlen csapvíz fémes szennyeződéseiből, jelen munkánk eredményei alapján ezen bimetál részecskék mennyisége a tiszta vas nanorészecskékhez képest annyira kicsi, hogy gyakorlati szempontból bármilyen hatásuk nyugodtan elhanyagolható.

\subsubsection{Röntgendiffraktometriás vizsgálatok - kristályszerkezet}

A nanorészecskék röntgen diffraktogramján (5.3. ábra) az elemi állapotú vasra jellemző reflexiók azonosíthatóak $45^{\circ}$ és $65^{\circ} 2 \Theta$ szögeknél. A JCPDS kártyák alapján ezekhez a csúcsokhoz a (110) és (200) Miller indexek tartoznak. Ezek a reflexiók a nátrium-borohidriddel redukált vas minták $\left(\mathrm{nZVI}_{\mathrm{Cl} 2}{ }^{\mathrm{B}}, \mathrm{nZVI}_{\mathrm{Cl} 3}{ }^{\mathrm{B}}\right.$ és $\mathrm{nZVI}_{\mathrm{S}}{ }^{\mathrm{B}}$ minták) esetében hangsúlyosabban jelennek meg. A megfigyelhető egyéb, kevésbé intenzív reflexiók a vas-oxid állapothoz tartoznak. A szakirodalom alapján a vas nanorészecskéket a felületükön kialakult, vékony vas-oxid réteg veszi körül ${ }^{70}$, így mérési eredményeink alapján elfogadhatjuk azt, hogy mintáink a nulla vegyértékü vas nanorészecskék mellett részben vas-oxidokat is tartalmazhatnak. 


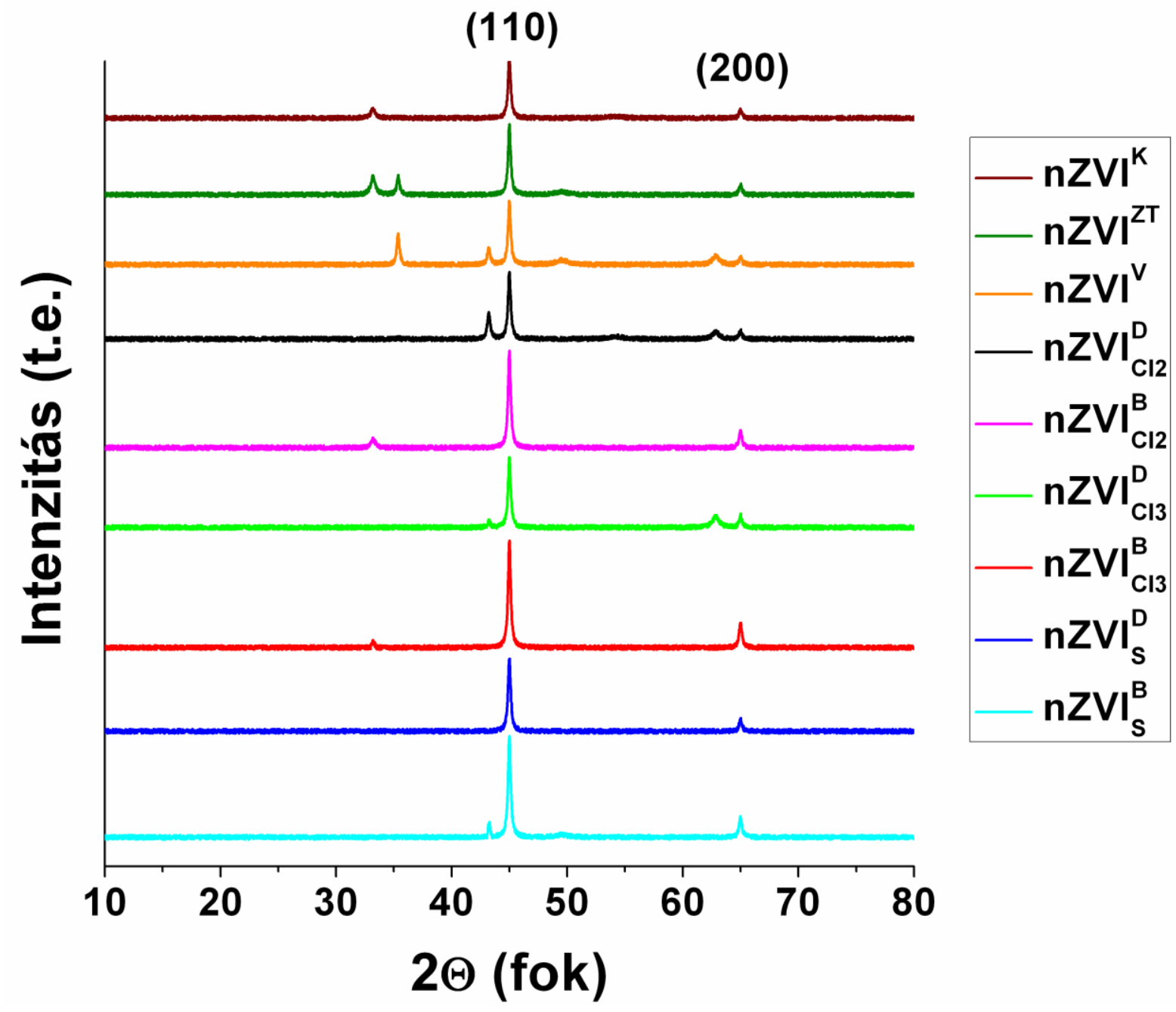

\section{3. ábra. Az előállított vas nanorészecskék röntgendiffraktogramjai}

A diffraktogramokat áttekintve jól látható, hogy a $\mathrm{nZVI}_{\mathrm{S}}{ }^{\mathrm{D}}$ minta volt a legkevésbé érzékeny az oxigén jelenlétére, míg a három zöld módszerrel előállított és a $\mathrm{nZVI}_{\mathrm{Cl} 2}{ }^{\mathrm{D}}$ minta volt a legkevésbé toleráns az oxidációval szemben (5.3. ábra).

\subsubsection{Redoxpotenciál mérések - redukciós kapacitás}

Korábbi tanulmányok alapján elmondható, hogy a nanovas szuszpenziók reduktív dehalogenizációs képességének meghatározásában a redoxpotenciál érték egy jó indikátor lehet ${ }^{204}$. A félig-zöld és a zöld módszerekkel elöállított 5000 ppm koncentrációjú nanovas szuszpenziók redoxpotenciál értékeinek változását az eltelt idő függvényében az 5.4. ábra szemlélteti. A redoxpotenciál mérések eredményeit, átlag-szórás értékeit 5 független kísérlet alapján határoztuk meg. 


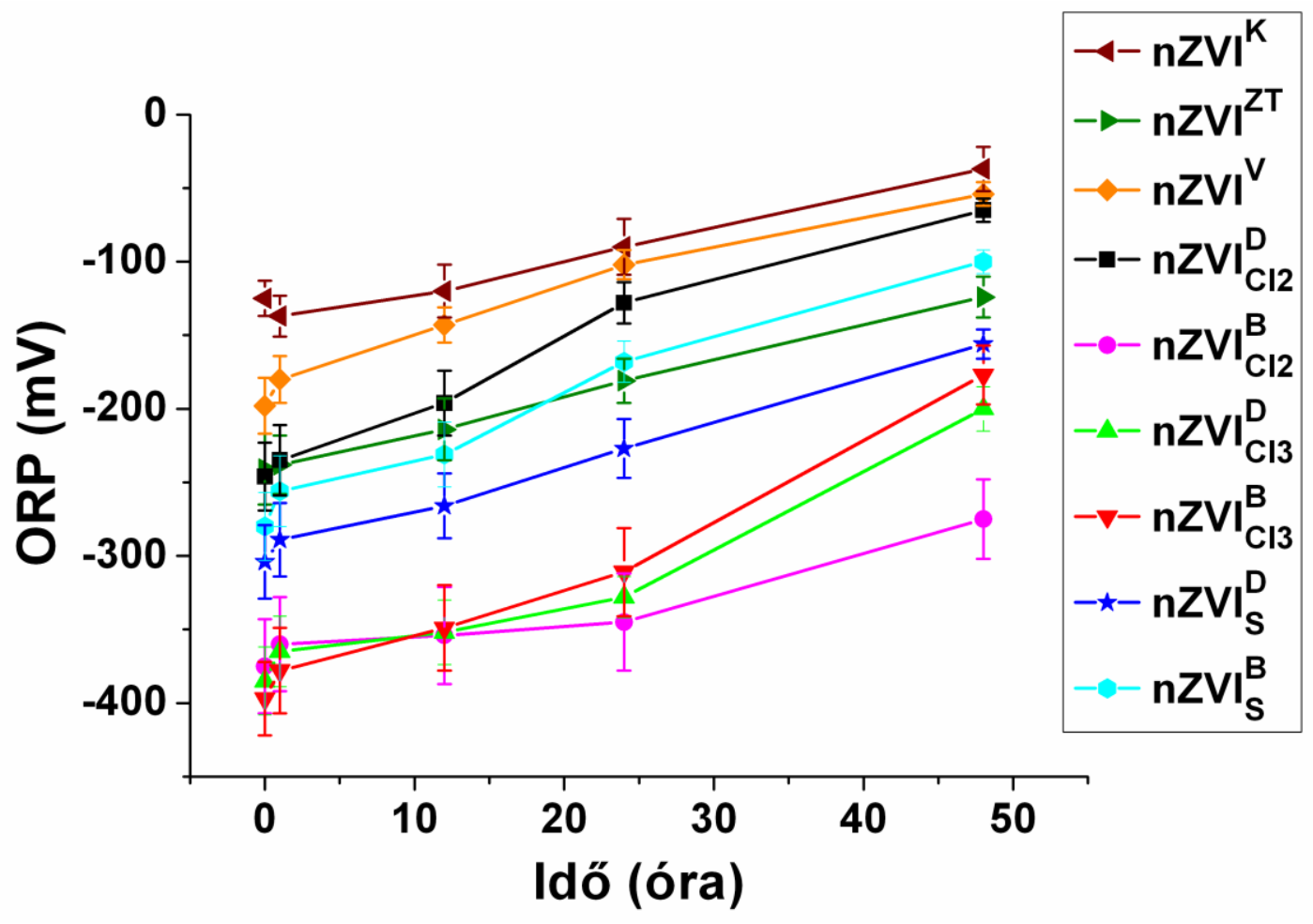

5.4. ábra. A különböző redukálószerekkel előállított nanovas szuszpenziók redoxpotenciál értékeinek változása az idő függvényében

A kapott eredmények alapján a növényi kivonatok segítségével elöállított vas nanorészecskék redoxpotenciál értékei a $-250 \mathrm{mV}$ és a $-100 \mathrm{mV}$ közötti intervallumba estek közvetlenül a szintézis után, majd a redukciós kapacitásuk az idő múlásával lineárisan csökkent. Megfigyeléseink alapján a kiindulási redoxpotenciál értékeket nem befolyásolta, ha a szintézis időtartamát 24 óra helyett 36 vagy 48 órára növeltük. A zöld nanovas minták közül a legnegatívabb $(-241 \mathrm{mV})$ és legpozitívabb $(-125 \mathrm{mV})$ kiindulási redoxpotenciál értéket a zöld teával, illetve a kávéval előállított vas nanorészecskék esetében mértük. Meglepő módon, a vadszőlölevél segítségével készült vas nanorészecske redukciós kapacitása $(-198 \mathrm{mV})$ felülmúlta az irodalomban dicsért kávékivonattal készült nanovas aktivitását ${ }^{205}$. Bár ez egyrészt magyarázható ez előbbi magas antioxidáns tartalmával ${ }^{206}$, másrészt lehetséges, hogy olyan márkájú kávét választottunk ki kísérleteinkhez, amely az átlagosnál kevesebb antioxidáns hatással rendelkező aktív komponens tartalmazott.

A félig-zöld eredetü nanovas szuszpenziók redoxpotenciál értékei alacsonyabbak voltak, tehát ezek a vas minták jobb redukciós kapacitással rendelkeztek, mint a teljesen zöld szintézismódszerrel előállított minták, kivéve a gyengén teljesítő $\mathrm{nZVI}_{\mathrm{Cl} 2}{ }^{\mathrm{D}}$ mintát. Ezek az értékek ugyancsak növekedtek az idő múlásával, tehát a minták redukciós kapacitása csökkent. A legjobb kezdeti redoxpotenciál értéket, azaz a legnagyobb reaktivitást, a nZVII ${ }_{\mathrm{Cl} 2}{ }^{\mathrm{B}}$ 
és $\mathrm{nZVI}_{\mathrm{Cl}}{ }^{\mathrm{B}}$ minták esetében mértük, ami összhangban van az irodalomban fellelhető eredményekkel $^{207,208}$. Másrészt viszont meg kell említenünk azt is, hogy ezek a minták voltak azok, éppen a nagy reaktivitásuk miatt, amelyek az idő múlásával a leggyorsabb ütemben, tehát a leghamarabb vesztették el a redukciós kapacitásukat. Figyelemreméltó, hogy az $\mathrm{nZVI}_{\mathrm{S}}^{\mathrm{D}}$ minta kiegyensúlyozott teljesítményt nyújtott a kísérlet során, mivel a szintézis után közvetlenül a harmadik legjobb kezdeti redoxpotenciál értékkel rendelkezett és redukciós kapacitása is csupán lineárisan csökkent.

Az 5.5. ábra a redoxpotenciál értékek változását mutatja be abban az esetben, amikor az nZVI mintákat 1 ekvivalens mennyiségü, szennyezett területről származó illékony klórozott szénhidrogént tartalmazó talajvíz mintával reagáltattuk.

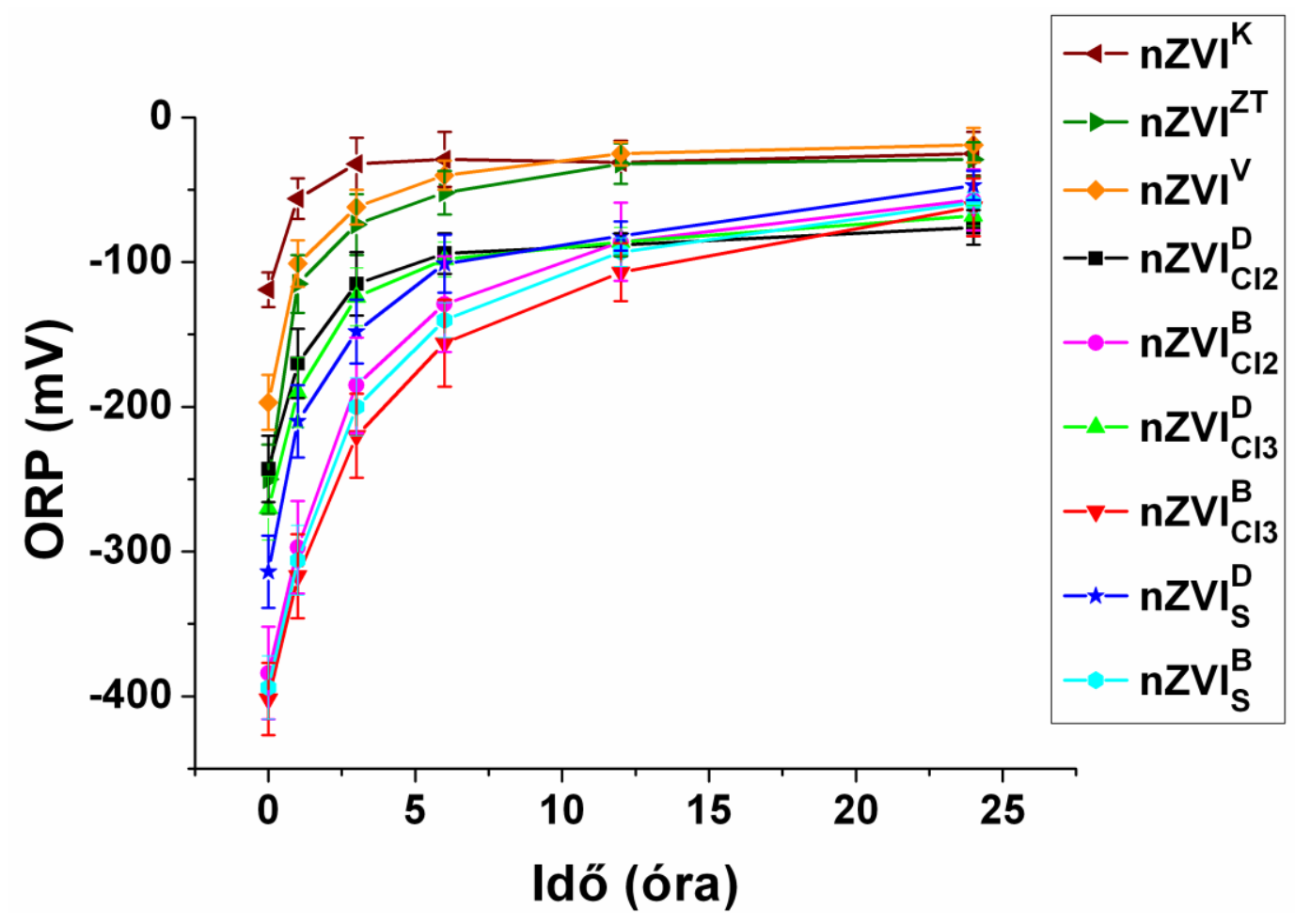

\section{5. ábra. A különböző redukálószerekkel előállított nanovas szuszpenziók redoxpotenciál értékeinek változása 1 ekvivalens mennyiségü, szennyezett területről származó illékony klórozott szénhidrogént tartalmazó talajvíz mintával való reagáltatás során}

A görbe „telítettsége” jelzi a reakció tulajdonképpeni végpontját. Mind a kilenc minta esetében azt tapasztaltuk, hogy a redukciós kapacitás kezdetben nagyon gyorsan lecsökkent. Ez a változás a vas nanorészecskék és az illékony klórozott szénhidrogének között végbemenő dehalogenizációs reakció egyértelmű jeléül szolgált.

Míg a kávé és a zöld tea kivonatokkal előállított nanovas minták esetében tapasztalt dehalogenizációs aktivitás megerősíti a korábban publikált eredményeket, a vadszőlő kivonat 
segítségével elöállított vas nanorészecskék tulajdonságairól elsőként közöltünk az irodalomban adatokat ${ }^{209}$.

Ahogyan az várható volt, azok a vas minták, amik nagyobb kezdeti redukciós kapacitással rendelkeztek, sokkal tovább maradtak aktívak. Míg a $\mathrm{nZVI}^{\mathrm{K}}$ minta 3 óra múlva teljesen elvesztette a redukciós kapacitását, addig a $\mathrm{nZVI}_{\mathrm{Cl} 2}{ }^{\mathrm{B}}, \mathrm{nZVI}_{\mathrm{Cl} 3}{ }^{\mathrm{B}}$ és $\mathrm{nZVI}_{\mathrm{S}}{ }^{\mathrm{D}}$ minták legalább 24 órán keresztül aktívak maradtak. Érdekes megfigyelni, hogy pontosan ennél a három mintánál kaptuk a legkisebb méretü nanorészecskéket (lásd TEM analízis), ami alátámaszthatja megtartott redukciós aktivitásukat. Ugyanis minél kisebbek a részecskék, annál nagyobb a fajlagos felületük, következésképpen nagyobb aktív felülettel rendelkeznek az illékony klórozott szénhidrogének lebontására. Ugyanakkor a nagyobb reaktív felület az oldott oxigén által indukált oxidatív deaktiválás (passziválás) lehetőségét is növeli. A mérések alapján ezt a lehetséges káros mellékhatást az említett három minta esetén a nagyon kis méretű nanorészecskék nagy száma és igen erős aktivitása kétségtelenül ellensúlyozza.

Összegezve, a fentiek alapján megállapítható, hogy a növényi kivonatokkal előállított vas szuszpenziók alkalmazása környezeti kármentesítésben nem, vagy csak nagyobb kompromisszumok mellett javasolt. Mivel a kávé és tea kivonattal készült vas nanorészecskék nagyobb részecskemérettel rendelkeztek, szintézis után könnyen aggregálódtak, redukálóképességük gyorsan lecsökkent. Habár a vadszőlő kivonat alkalmazásával megfelelöbb méretü vas nanorészecskéket sikerült előállítanunk, ez a minta is hamar, 3 óra elteltével elvesztette redukciós kapacitását. Így a továbbiakban csak a félig-zöld módszerrel előállított vas nanorészecskék lehetséges remediációs alkalmazásának vizsgálatát folytattuk.

\subsubsection{Hidrogéngáz fejlödés vizsgálat - hatékonyság}

A félig-zöld módszerrel elöállított vas szuszpenziók hatékonyságát kénsavas reagáltatással vizsgáltuk. A koncentrált kénsav és a félig-zöld úton előállított nanovas minták reakciója közben felszabaduló hidrogén mennyiségét oxigén jelenlétében, csapvízben és oxigénmentes, inert környezetben (a szuszpenziók előállítása és vizsgálata nitrogéngáz bevezetése mellett történt) is megfigyeltük.

A kapott eredményekböl ún. nZVI hatékonysági százalékot számoltunk, ahol a 100\%-os hatékonyságnak azt vettük, amikor a rendszerben jelenlévő összes vas (sztöchiometriailag) elreagál a kénsavval, vagyis az összes vas $\mathrm{Fe}^{0}$ állapotúnak tekinthető. A kapott eredményeket az 5.6. ábra foglalja össze. 
Jól látható, hogy a mért eredmények összhangban vannak a redoxpotenciál méréseknél kapott eredményekkel, a legjobb hatékonyságot mindkét méréssorozatban a nátrium-borohidriddel redukált vas minták $\left(\mathrm{nZVI}_{\mathrm{Cl} 2}{ }^{\mathrm{B}}\right.$, a $\mathrm{nZVI}_{\mathrm{Cl} 3}{ }^{\mathrm{B}}$ és $\mathrm{nZVI}_{\mathrm{S}}{ }^{\mathrm{B}}$ minták) mutatták.

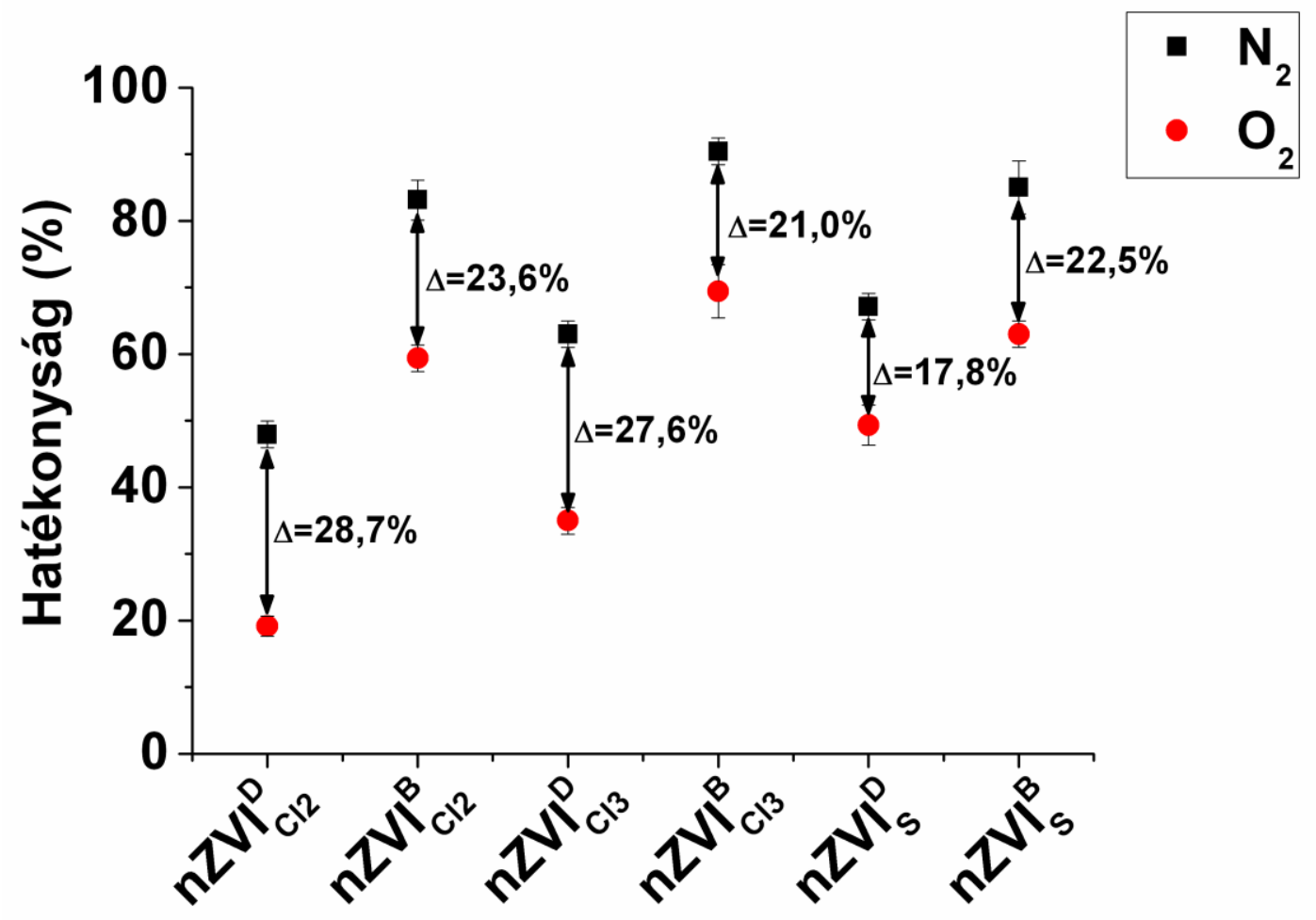

5.6. ábra. A különböző redukálószerrel előállított nanovas szuszpenziók hatékonysága. A hatékonyság a nanovas szuszpenziók koncentrált kénsavval való reagáltatása során fejlődő hidrogéngáz mennyiségéből számolt érték. A piros körök (•) az oxigén jelenlétében, csapvízben; a fekete négyzetek ( $\square$ ) az oxigénmentes, inert környezetben kapott értékek.

Érdemes megjegyezni, hogy a röntgendiffrakciós mérések eredményeivel egybevágóan, ennél a kísérletsorozatnál is a $\mathrm{nZVI}_{\mathrm{Cl2}}{ }^{\mathrm{D}}$ minta volt a legkevésbé toleráns az oxigén jelenlétére $(\Delta=28,7 \%)$. Míg a legrobosztusabbnak a nZVI ${ }^{\mathrm{D}}$ minta bizonyult, mivel az oxigénmentes és a terepi körülmények között mért hatékonyságok itt tértek el a legkisebb mértékben egymástól $(\Delta=17,8 \%)$.

\subsubsection{Illékony klórozott szénhidrogének bontásának vizsgálata}

\section{laboratóriumi körülmények között}

Mind a hat félig-zöld kémiai módszerrel előállított nanovas szuszpenzió degradációs hatékonyságát vizsgáltuk egy illékony klórozott szénhidrogénnel szennyezett területről származó talajvíz mintában.

A környezetvédelmi kármentesítési gyakorlatban bevett szokás, hogy az esetleges redukciós kapacitás csökkenés kompenzálása végett a redukálószereket feleslegben 
alkalmazzák a remediáció során. A redukciós kapacitás csökkenése oxidatív környezetben bekövetkezhet, például az egyéb, nem-dehalogenációs reakciók lejátszódása miatt ${ }^{74}$.

Meg szerettük volna vizsgálni, hogy a szuszpenziók feleslegben való adagolása, valamint a szuszpenziók koncentrációjának növelése hogyan befolyásolja a szuszpenziók illékony klórozott szénhidrogén lebontó hatását. Ezért a nanovas szuszpenziókat mind a hat félig-zöld szintézismódszerrel 2500, 5000 és 10000 ppm koncentrációban is elkészítettük, és az ekvimoláris mennyiségü adagolás mellett, kétszeres és háromszoros felesleg alkalmazásával is végeztünk méréseket.

A szennyezett talajvízhez adagolva a különböző szuszpenziókat, 6 óra elteltével, a talajvízben található illékony klórozott szénhidrogénre nézve mért redukciós hatékonyságok adatait az 5.7. ábra mutatja. A lebontó hatást hatékonysággal fejeztük ki, amely fogalom alatt a talajvíz mintában található illékony klórozott szénhidrogének valamilyen mértékü nanovas általi lebontását értjük. A lebontási hatékonyság százalékos értékét a következőképpen számoltuk ki: a 6 óra után jelen lévő illékony klórozott szénhidrogének összkoncentrációját elosztottuk a kiindulási illékony klórozott szénhidrogének összkoncentrációjával; a 100\%-os hatásfok így azt jelenti, amikor a vízből az összes illékony klórozott szénhidrogént sikeresen eltávolítjuk.

Az 5.8. ábra mutatja a szennyezett talajvíz illékony klórozott szénhidrogén összetételének általunk megfigyelt jellemző változását a különböző vasrészecskékkel való reagáltatás során. Az ábra az 5000 ppm-es koncentrációjú $n Z \mathrm{VI}_{\mathrm{S}}{ }^{\mathrm{B}}$ mintával való reakciót mutatja. Mindegyik vas adagolásánál hasonló tendenciájú, kissé eltérő mértékü bontást figyeltünk meg (5.7. ábra). Jól látható, hogy a fő szennyezők (TCE, cDCE) mennyisége jelentősen lecsökkent ( $60 \%$ ), és az egyéb toxikus köztitermékek sem halmozódtak fel.

A hatékonysági vizsgálat adatai alapján a következő megfigyeléseket tehetjük:

1) $\mathrm{Az}$ alkalmazott nanovas mennyiségének növelése kedvező hatással van az illékony klórozott szénhidrogén eltávolítására: az oldat koncentrációjától és az alkalmazott szintézistől függetlenül a nanovas háromszoros feleslegben adagolása megközelítőleg megduplázta a dehalogenizációs potenciált.

2) Az előállítás módja ugyancsak jelentősen befolyásolja a minták teljesítményét: ugyanolyan körülmények között, mindhárom koncentráció esetén, a leghatékonyabbnak nevezhető $\mathrm{nZVI}_{\mathrm{Cl} 3}{ }^{\mathrm{B}}$ minta csaknem háromszorosan felülmúlta a leggyengébben teljesítő $\mathrm{nZVI}_{\mathrm{Cl} 2}{ }^{\mathrm{D}}$ mintát.

3) Eredményeink alátámasztják az irodalomban közölt eredményeket, melyek szerint a nátrium-borohidrid segítségével előállított vas minták nagyobb 
hatékonyságot mutatnak a szennyezők lebontása során, mint a nártium-ditionittal redukált vas minták ${ }^{118}$.

4) Emellett minden összetételnél megfigyelhetö, hogy az 5000 ppm-es koncentrációjú minták mutatták a legnagyobb hatékonyságot. A jelenség azzal magyarázható, hogy míg alacsonyabb vas koncentráció (2500ppm) mellett a vas nanorészecskéket felhasználó mellékreakciók kapnak viszonylag fontosabb szerepet (a kevesebb vas nanorészecske arányosan nagyobb része passziválódik), addig magas vas koncentráció $(10000$ ppm) esetén megnő a részecskék aggregációjának valószínüsége (térfogat-felület arány kedvezőtlenebbé válik). Mivel mindkét folyamat a redukciós kapacitás csökkenéséhez járul hozzá, ezért javasolt a köztes, az 5000 ppm-es koncentráció alkalmazása. 

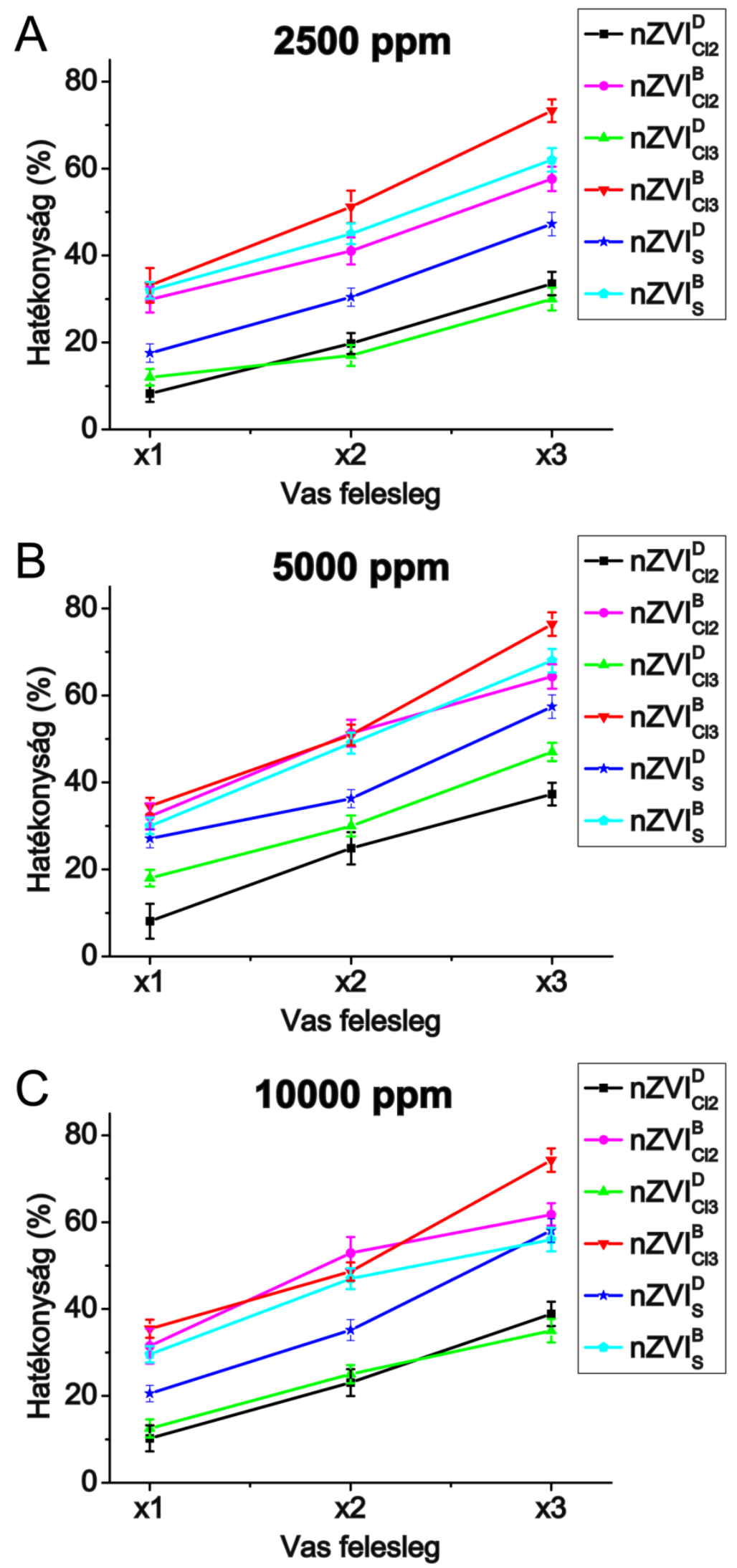

5.7. ábra. A különböző redukálószerekkel előállított nanovas szuszpenziók redukálóképessége. A nanovas szuszpenziókat 2500 ppm (A), 5000 ppm (B) és 10000 ppm (C) koncentrációban reagáltattuk illékony klórozott szénhidrogénnel szennyezett talajvízzel. 


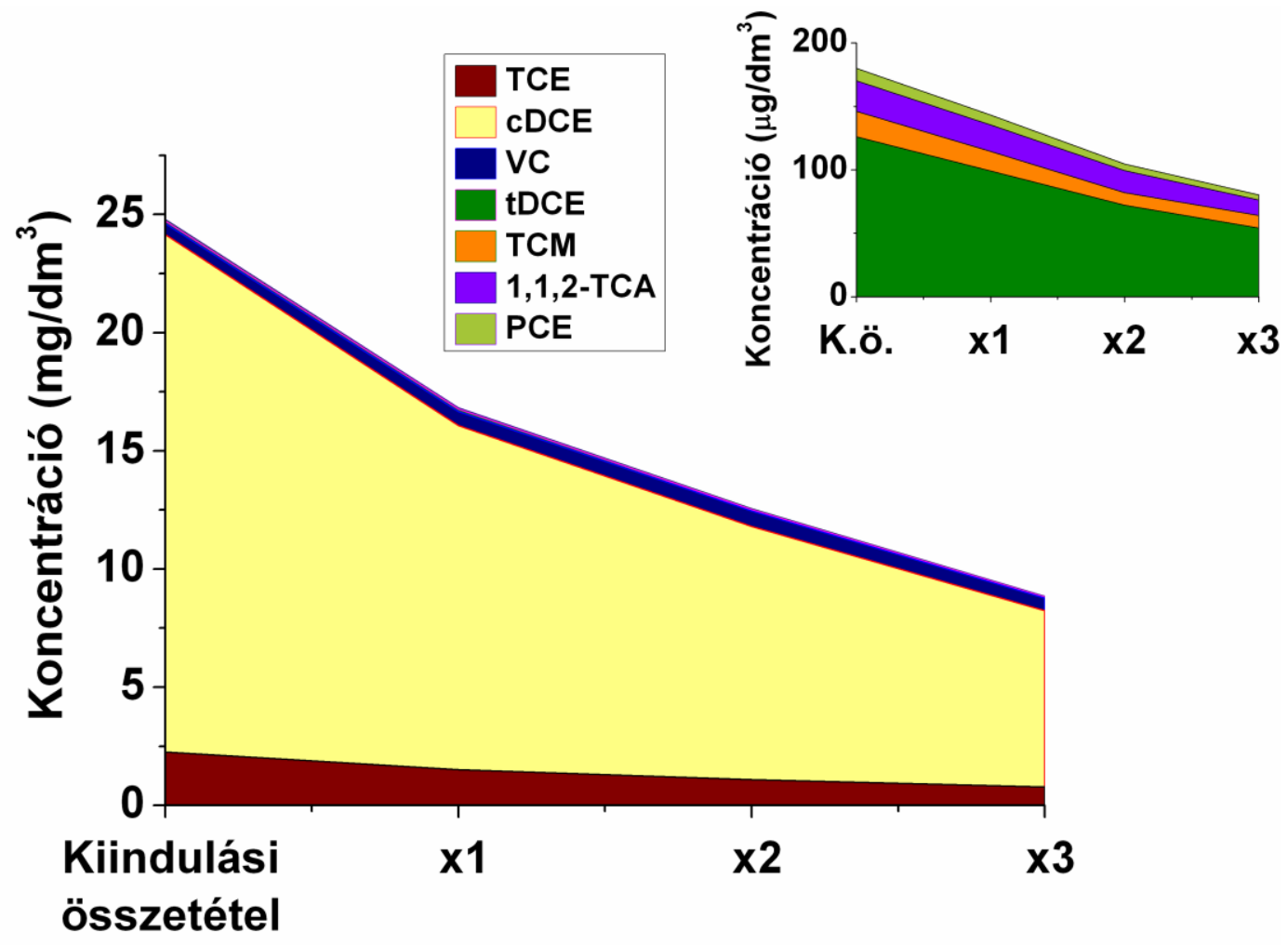

\section{8. ábra. A kezelt talajvíz illékony klórozott szénhidrogén összetételének változása a} nanovas adagolás $\left(5000 \mathrm{ppm} n Z V I_{S}{ }^{B}\right)$ hatására. Az ábrán szereplő szennyezőanyagok: tetraklóretilén (PCE), triklóretilén (TCE), cisz- és transz diklóretilén (c- és tDCE), vinil-klorid (VC), triklórmetán (TCM) és 1,1,2-triklóretán (1,1,2 TCA).

\subsubsection{Vas nanorészecskék alakját befolyásoló védőmolekula adagolása}

A félig-zöld szintézis során a mintákhoz a redukálószer mellett polivinil-pirrolidont (PVP) adagoltunk inert atmoszférában, a szintézis többi paraméterét nem változtatva, hogy megvizsgáljuk a keletkező nanorészecskék morfológiájára gyakorolt hatását. Az irodalomból jól ismert, hogy a PVP mint védőmolekula befolyásolja a szilárd kristály különböző lapjainak növekedési sebességét, anizotróp kristálynövekedést eredményezve ${ }^{210}$.

A vizsgált négy minta $\left(\mathrm{nZVI}_{\mathrm{S}}{ }^{\mathrm{D}}, \mathrm{nZVI}_{\mathrm{Cl}}{ }^{\mathrm{D}}, \mathrm{nZVI}_{\mathrm{Cl} 3}{ }^{\mathrm{B}}\right.$ és $\left.\mathrm{nZVI}_{\mathrm{S}}{ }^{\mathrm{B}}\right)$ esetében, a $0,3 \%$-os adagolás során alakszelektivitást figyeltünk meg, hasonlóan Choi és munkatársai által leírtakhoz ${ }^{157}$. Habár a TEM felvételek alapján a szálas szerkezet kialakulása csak a $\mathrm{nZVI}_{\mathrm{Cl}}{ }^{\mathrm{D}}$ minta esetében volt domináns, a $\mathrm{nZVI}_{\mathrm{S}}{ }^{\mathrm{D}}$ és $\mathrm{nZVI}_{\mathrm{Cl} 3}{ }^{\mathrm{B}}$ mintáknál is megfigyelhetőek anizotróp nanoszálak a nanorészecskék mellett (5.9. ábra). A kapott nanoszerkezetek jellemzőit az 5.1. táblázat foglalja össze. Jól látható, hogy a különböző alakú nanoszerkezetek hatékonysága hasonló volt a PVP adagolás nélküli minták hatékonyságához (5.7. ábra). Kisebb mértékü hatékonyság csökkenés volt tapasztalható a $\mathrm{nZVI}_{\mathrm{Cl} 13}{ }^{\mathrm{D}}$ és $\mathrm{nZVI}_{\mathrm{S}}{ }^{\mathrm{B}}$ minták esetében, ami valószínűleg a kialakult nanoszerkezetek eltérő fajlagos felületével magyarázható ${ }^{116}$, de ezt 
külön nem vizsgáltuk. Valószínűsíthetően a reakció idejének növelésével a nZVI ${ }_{S}{ }^{\mathrm{B}}$ mintában is megfigyelhetőek lettek volna az anizotróp nanoszerkezetek ${ }^{157}$. Habár a PVP segítségével befolyásolható a kialakuló nanokristályok alakja, a folyamatban betöltött pontos szerepe és maga a folyamat mechanizmusa csak hiányosan ismert ${ }^{211}$.
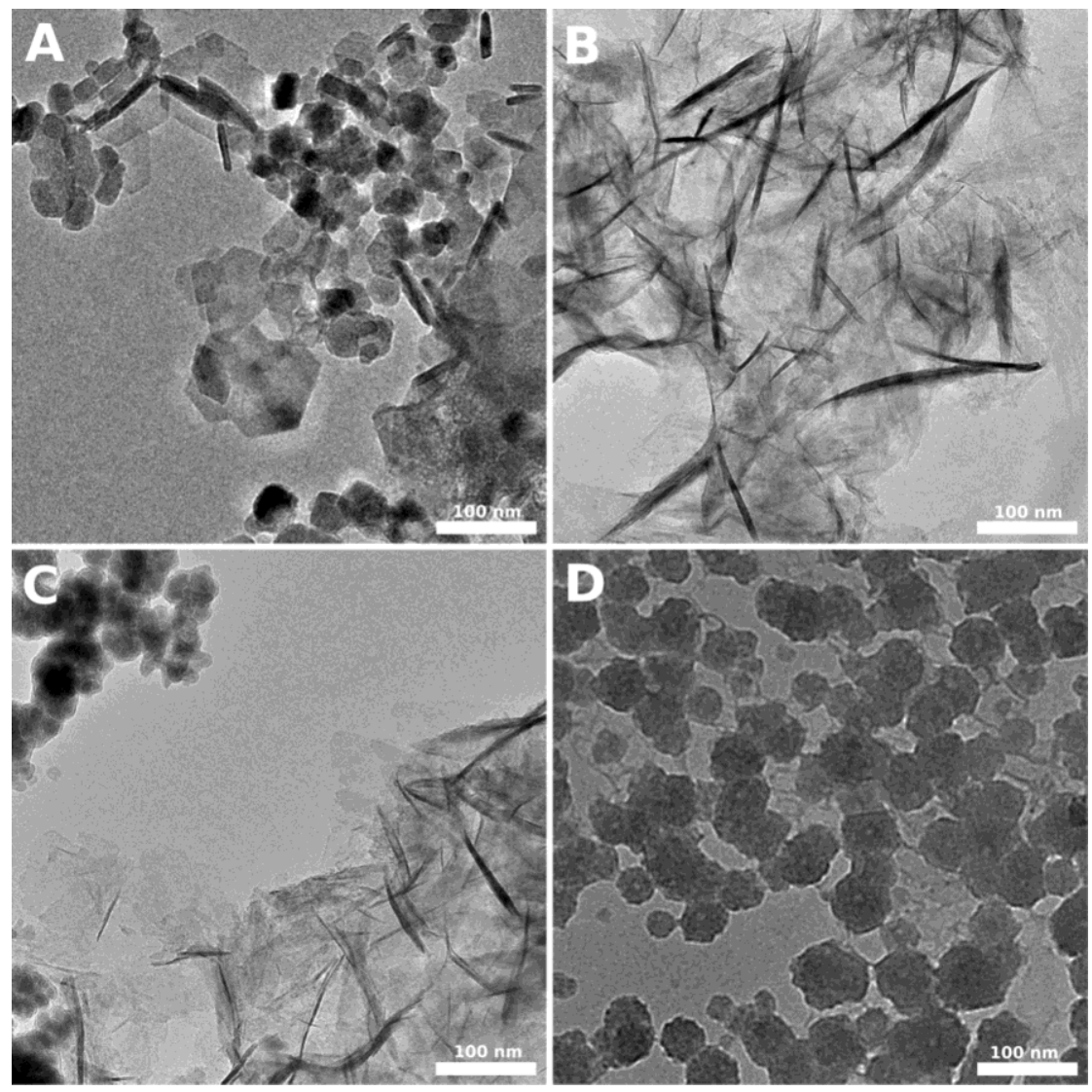

5.9. ábra. A PVP adagolás hatására kialakult nanoszerkezetek TEM felvételei: $\mathrm{nZVI}_{\mathrm{S}}^{\mathrm{D}}$ (A), nZVI ${ }_{\mathrm{Cl3}}^{\mathrm{D}}(\mathrm{B}), \mathrm{nZVI}_{\mathrm{Cl3}}^{\mathrm{B}}{ }^{\mathrm{C}}$ (C) és nZVI ${ }_{\mathrm{S}}^{\mathrm{B}}$ (D)

5.1. táblázat A PVP adagolás hatására kialakult nanoszerkezetek jellemzői

\begin{tabular}{lcccc}
\hline & $\begin{array}{c}\text { Nanorészecske } \\
\text { átmérö }(\mathbf{n m})\end{array}$ & $\begin{array}{c}\text { Nanoszál } \\
\text { hossz }(\mathbf{n m})\end{array}$ & $\begin{array}{c}\text { Nanoszál } \\
\text { átmérö }(\mathbf{n m})\end{array}$ & $\begin{array}{c}\text { Hatékonyság } \\
(\%)\end{array}$ \\
\hline $\mathbf{n Z V I}_{\mathbf{S}}{ }^{\mathbf{D}}$ & $43,1 \pm 17,7$ & $64,9 \pm 23,8$ & $9,0 \pm 3,3$ & $70,9 \pm 2,2$ \\
$\mathbf{n Z V I}_{\mathbf{C l 3}} \mathbf{D}$ & - & $105,9 \pm 36,0$ & $2,5 \pm 2,6$ & $83,0 \pm 2,5$ \\
$\mathbf{n Z V I}_{\mathbf{C l 3}} \mathbf{B}$ & $29,6 \pm 10,1$ & $74,9 \pm 32,5$ & $1,3 \pm 1,5$ & $96,0 \pm 3,1$ \\
$\mathbf{n Z V I}_{\mathbf{S}}^{\mathbf{B}}$ & $48.1 \pm 13.2$ & - & - & $93,1 \pm 2,7$ \\
\hline
\end{tabular}




\subsubsection{A kiválasztott minta terepi tesztelése}

A mai napig számos publikációban számoltak be a szennyezett talajvizek helyreállításában sikeresen alkalmazható nulla vegyértékü vas nanorészecskék szintéziséről és jellemző tulajdonságairól ${ }^{212}$. Ugyanakkor jelenleg csak csekély számban érhetőek el a vas nanorészecskék terepi méretű felhasználásáról szóló beszámolók ${ }^{213-217}$.

A mintánk terepi tesztelése egy nagyméretü remediációs projekt keretén belül valósult meg 2014-2015-ben az Alföld délkeleti részén. A terepi tesztekhez a félig-zöld módszerrel előállított $\mathrm{nZVI}_{\mathrm{S}}{ }^{\mathrm{D}}$ mintát választottuk a következő okok miatt:

1. jelentősen jobb redoxpotenciál értékkel rendelkezett, mint bármelyik növényi kivonattal elöállított nanovas szuszpenzió;

2. laboratóriumi tesztjeink során az illékony klórozott szénhidrogének lebontásába kiegyensúlyozott teljesítményt nyújtott mind a redoxpotenciálon alapuló, mind a gázkromatográfiás mérések alapján;

3. költséghatékonysága mellett nem szennyezi mérgező bórvegyületekkel a környezetet.

A szennyezett területen az injektáláshoz és a talajvíz monitorozásához szükséges kutakat rácsszerüen helyezték el. A mintákat szilikon csöveken keresztül vették és a teljesen megtöltött üvegedényeket sötétben, $4{ }^{\circ} \mathrm{C}$-on tárolták a vizsgálatok elvégzéséig. A mintavételek tervezetten csapadékmentes időszakban történtek: a talajvíz felszíni forrásból történő (hó vagy eső) esetleges hígításának elkerülésére a mintákat legalább 2 száraz, csapadékmentes nap után vették. Az 5.2. táblázat tartalmazza az injektálási és mintavételi napok időjárási viszonyait.

5.2. táblázat. Időjárási viszonyok az injektálási és mintavételi napok

\begin{tabular}{lccccc}
\hline Dátum & $\begin{array}{c}\text { Levegó } \\
\text { hőmérséklete } \\
\left({ }^{\circ} \mathbf{C}\right)\end{array}$ & $\begin{array}{c}\text { Csapadék } \\
(\mathbf{m m})\end{array}$ & $\begin{array}{c}\text { Páratartalom } \\
(\mathbf{R H \%})\end{array}$ & $\begin{array}{c}\text { Légnyomás } \\
(\mathbf{h P a})\end{array}$ & $\begin{array}{c}\text { Szélsebesség } \\
\left(\mathbf{k m} \cdot \mathbf{h}^{-\mathbf{1}}\right)\end{array}$ \\
\hline 2014.09.17. & 16 & 0 & 88 & 1020 & 0 \\
2014.09.19. & 21 & 0 & 41 & 1021 & 1,8 \\
(injektálás) & 4 & 0 & 95 & 1033 & 3,6 \\
2014.10.27. & 8 & 0 & 44 & 1028 & 3,6 \\
2014.11.24. & 1 & 0 & 99 & 1026 & 7,2 \\
2014.11.26. & 1 & 0 & 93 & 1021 & 9,3 \\
(injektálás) & 8 & 0 & 81 & 1019 & 20,4 \\
2014.12.03. & 8 & 0,1 & 100 & 1015 & 3,7 \\
2014.12.19. & 6 & & & & \\
2015.01 .21$. & & & & &
\end{tabular}


A kezelt terület talajrétegei a következőképpen néznek ki: a legfelső vékony réteg a 10-15 cm vastag termőtalaj. Ezt az agyagos réteg követi -3 méterig, majd -5 méterig a homokos-földes-agyag réteg található. Ezután -5 és -12 méter között váltakozva homokosföldes-agyag és iszapos agyag rétegek vannak, majd -12 és -25 méter között egy agyag réteg következik. -22 méternél egy 0,5 méter vastag homokos-agyagos réteg van az agyagrétegbe ágyazva. A talajvíz szintje -5 méternél volt a beavatkozás területén. A vizsgált területen a pórusnyomás-gradiens értéke $40 \mathrm{kPa} \cdot \mathrm{m}^{-1}$ volt, azonban -12 méternél a várt $480 \mathrm{kPa}$ helyett egy jóval alacsonyabb, 100-180 kPa pórusnyomást lehetett mérni, ami megkönnyítette az injektálást ebben a mélységben.

A területen azonosított legfőbb szennyezők az illékony klórozott szénhidrogének voltak: perklóretilén (PCE), triklóretilén (TCE), diklóretilén (DCE, cisz- és transz együttesen) és vinil-klorid (VC). A szennyezők kezdeti koncentrációját a talajvízben 2014. 09. 17-én mérték, majd 2014. 09. 19-én történt az első injektálás. Az első injektálás alkalmával több, mint $500 \mathrm{dm}^{3} 5000$ ppm koncentrációjú $\mathrm{nZVI}_{\mathrm{S}}^{\mathrm{D}}{ }^{\mathrm{D}}$ szuszpenziót juttattak a talajba -12 méternél. Ezután megkezdődött a monitorozás fázisa. A monitoring kutak az injektáló ponttól 5 méter távolságra helyezkednek el. A második injektálás teljesen hasonló környezeti és müszaki paraméterek mellett történt 2014. 11. 26-án. A talajvíz monitorozása 2015 januárjában fejeződött be. Az 5.10. ábra mutatja a legfőbb illékony klórozott szennyezők koncentrációjának változását a beavatkozás ideje alatt a kiválasztott monitoring kútban.

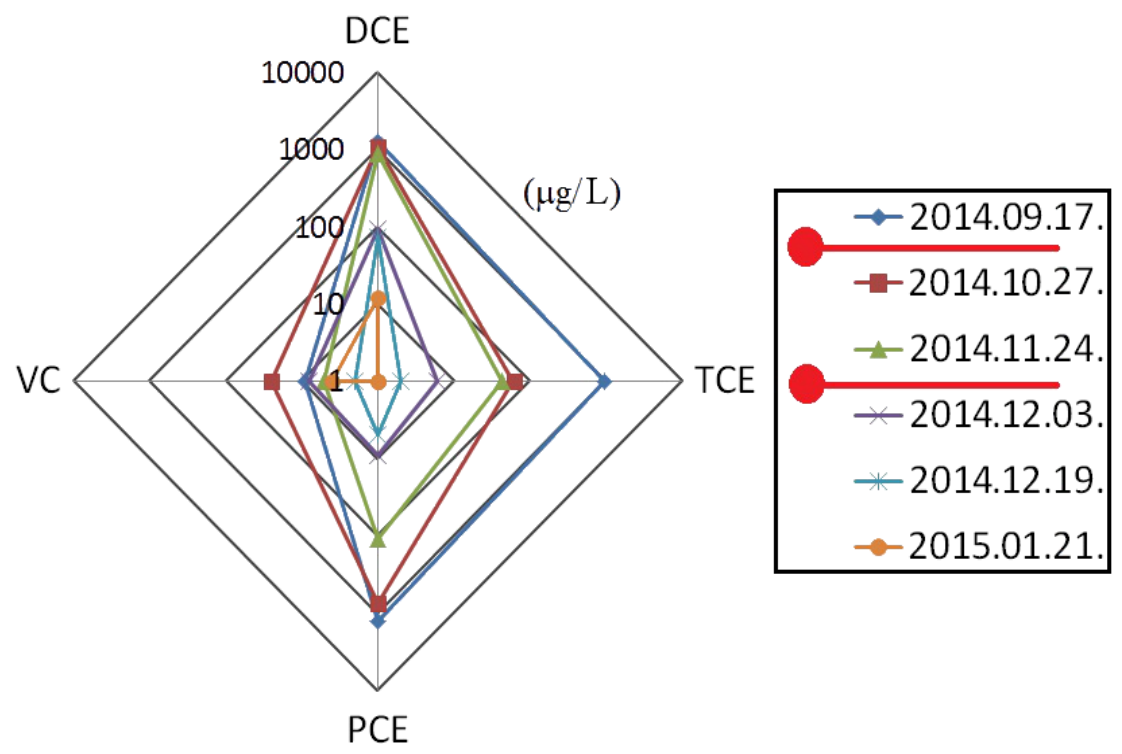

5.10. ábra. A megvalósult terepi teszt eredménye: Az 5000 ppm koncentrációjú nZVI ${ }_{S}^{D}$ szuszpenzióval kezelt illékony klórozott szénhidrogénekkel szennyezett területen a szennyezők koncentrációjának változása az idő függvényében egy kiválasztott monitoring kútban. A pirossal jelölt pontok az injektálások dátumait jelölik. 
Jól látható, hogy sem a PCE, sem a TCE nem volt kimutatható az utolsó mintavétel során a talajvízmintákban, valamint a DCE és VC mennyisége is $15 \mu \mathrm{g} / \mathrm{L}$ alá csökkent. Az eredmények alapján tehát elmondhatjuk, hogy a félig-zöld szintézis során elöállított $n Z V_{S}{ }^{D}$ minta terepi tesztelése sikeres volt, alkalmazása egy környezetkímélőbb, költséghatékonyabb alternatívát jelenthet a környezeti kármentesítésben.

Összegezve, sikeresen állítottunk elő szobahőmérsékleten, környezeti körülmények mellett különböző vas nanorészecskéket erőforrás-igényes deoxigenált oldószerek helyett csapvíz használatával. Meghatároztuk az előállított vas nanorészecskék átlagos szemcseméretét, kristályszerkezetét és redukciós kapacitását. Habár a félig-zöld úton előállított vas nanorészecskék kisebb átlagos átmérővel és nagyobb redukciós potenciállal rendelkeztek, mint a teljesen zöld szintézissel készült minták, az utóbbiak is elfogadható teljesítményt nyújtottak kísérleteink során.

Ezenkívül a szakirodalomban elsőként írtunk a vas nanorészecskék sikeres szintéziséről vadszőlőlevél (Parthenocissus quinquefolia, Virginia creeper) kivonat felhasználásával ${ }^{209}$.

Emelett kimutattuk, hogy mivel a nátrium-borohidrid sokkal drágább és toxikusabb vegyszer, mint a nátrium-ditionit, ezenfelül a belőle származó szintén toxikus bórvegyületek esetleges környezetbe kikerülése további környezetvédelmi problémát okoz, eredményeink alapján a környezeti remediációban egy fenntartható, hatékony, gazdaságos alternatív megoldás lehet a vasszulfátból nátrium-ditionittal redukált vas nanorészecskék $\left(\mathrm{nZVI}_{\mathrm{S}}{ }^{\mathrm{D}}\right)$ alkalmazása. Ugyanakkor további vizsgálatok és terepi tesztek szükségesek - úgy, mint a vas nanorészecskék talajban élő szervezetekre gyakorolt hatásának felmérése - a vas nanorészecskékkel történő remediációs beavatkozás pontos tervezéséhez, megértéséhez, hosszú távú hatásainak felbecsléséhez és egyéb szennyezett területeken való sikeres alkalmazásához. 


\subsection{Mikrokozmosz vizsgálatok: Nulla vegyértékü vas nanorészecskék hatása a klórozott alifás szénhidrogének degradációjára és a deklorinációban résztvevő szervezetekre}

Mint már bemutattuk, a klórozott alifás szénhidrogénekkel szennyezett területek a korábbi katonai, mezőgazdasági és ipari tevékenység hatására, számos helyen találhatóak hazánkban és az EU országaiban ${ }^{4,6,11}$. Ezeken a területeken a legtöbb esetben a talajvizek és a rétegvizek is szennyezettek, ami közvetlenül fenyegeti az ivóvízbázisokat, így hatékony kármentesítésük kiemelt fontosságú.

Az előző 5.1. fejezet eredményei alapján láttuk, hogy a vas nanorészecskék illékony klórozott szénhidrogének környezeti kármentesítésben sikeresen alkalmazhatóak. Ugyanakkor kimutattuk, hogy a szintézis során alkalmazott kiindulási vas-sók, redukálószerek és egyéb stabilizáló anyagok jelentősen befolyásolják a kapott vas nanorészecskék morfológiáját és aktivitását (hatékonyságát). Ezek után felmerül a kérdés, hogy vajon az eltérő tulajdonsággal rendelkező nanovasak a remediációs kezelés során hogyan befolyásolják a biológiai rendszereket, más-e a részecskék biológiai aktivitása is. A beavatkozás tervezésénél nagyon fontos, hogy figyelembe vegyük a remediáció közben és után a szennyezett területen kialakult mikroflóra állapotát, ami a későbbiekben meghatározhatja a megtisztított közeg hasznosíthatóságát.

Munkánk második részében a nanovasas beavatkozás hatékonyságának meghatározása mellett fel akartuk térképezni, hogy komplex ökológiai rendszerben a különböző típusú nanovasak milyen hatással vannak a klórozott alifás szénhidrogénnel szennyezett, nehezen hozzáférhető földtani közegek anaerob mikroflórájára, kiváltképp a deklorinációban résztvevő baktériumokra.

A környezeti kármentesítésnél a szennyezőanyagok sorsát, a degradációt, a mikrobiális közösség szerkezetének változásait, és a beavatkozás egyéb következményeit vizsgálhatjuk mikrokozmosz modellkísérletekben, amelyek a természetes környezet mesterségesen korlátozott részhalmazai, a természetes ökoszisztéma biológiai modelljei ${ }^{29}$. Segítségükkel pontosabban tervezhetővé válik a víznél nagyobb sürüségü, nehezen hozzáférhető, felszín alatti, klórozott alifás szénhidrogének in situ kezelése.

Kísérleteink során, a 4.3.12 fejezetben ismertetett módon összeállított mikrokozmosz rendszerekben anaerob körülmények között vizsgáltuk négy különböző tulajdonságú, félig-zöld módszerrel elöállított nulla vegyértékű vas nanorészecske $\left(\mathrm{nZVI}_{\mathrm{S}}^{\mathrm{D}}, \mathrm{nZVI}_{\mathrm{Cl}}{ }^{\mathrm{D}}\right.$, 
$\mathrm{nZVI}_{\mathrm{Cl} 3}{ }^{\mathrm{B}}$ és $\mathrm{nZVI}_{\mathrm{S}}{ }^{\mathrm{B}}$ ) hatását a klórozott szénhidrogének degradációjára és az anaerob mikroflórára, különös tekintettel a deklorinációban résztvevő baktériumokra.

Az elöállított nulla vegyértékủ vas nanorészecskék közül úgy választottunk ki négyet, hogy a szintézis során alkalmazott különböző redukálószerek anaerob mikroflórára gyakorolt esetleges hatását meg tudjuk vizsgálni. A minták közül kettő nátrium-ditionit, másik kettő pedig nátrium-borohidrid felhasználásával készült ugyanazon két kiindulási vas-só (vas(II)-szulfát és vas(III)-klorid) alkalmazásával, mindegyik minta tartalmazott továbbá 0,3\%-nyi PVP-t is. Habár a szintézis során adagolt PVP meghatározó befolyással volt a kialakuló részecskék morfológiájára egyes mintákban, a szakirodalmi adatok alapján, a biológiai rendszerek mikrobiális összetételére gyakorolt hatása ilyen koncentrációban elhanyagolható $^{218}$. Mindegyik minta eltérő morfológiával és reaktivitással rendelkezett (5.9. ábra, 5.1. táblázat). A batch kísérletekben a vas nanorészecskéket minden esetben $0,1 \mathrm{~g} / \mathrm{L}$-es koncentrációban alkalmaztuk, ami jóval alacsonyabb koncentráció, mint az előző fejezetben bemutatott vizsgálatok során alkalmazott koncentrációk. Alapos megfontolás után azért választottuk ezt a sokkal kisebb koncentrációt, mert habár a környezeti remediációban a nanovasat tízszer nagyobb ( $1 \mathrm{~g} / \mathrm{L}$ és felette) koncentrációban alkalmazzák, számos publikációban számoltak be baktériumok növekedésének gátlásáról a vas részecskék 0,1-0,25 g/L-es koncentrációban történő alkalmazása mellett ${ }^{93,94,107}$.

A különböző vas nanorészecskék adagolásának hatását mikrokozmosz rendszerekben tanulmányoztuk. DNS alapú mérésekkel követtük a reduktív deklorinációban résztvevő baktériumok jelenlétét, mennyiségét, ezen felül pedig elemeztük a mikroba közösség összetételét, illetve változását a különböző nanovas adagolás hatására. Az illékony klórozott szénhidrogének összetételének változását gázkromatográfiás mérésekkel vizsgáltuk. A mikrokozmoszokból a kiindulási, a 4., a 10., és a 20. napon vettünk mintákat.

\subsubsection{Különböző nulla vegyértékü vas nanorészecskék hatása a mikrobiális összetételre}

\subsubsection{Anaerob heterotróf élő sejtszám}

Anaerob heterotróf lemez értékeléssel (R2A agar, $25^{\circ} \mathrm{C}, 48$ óra inkubáció, anaerob környezet) meghatároztuk a tenyészthető heterotróf sejtek számát. Az 5.11. ábra mutatja a baktériumok szaporodásának dinamikáját. A vártnak megfelelően a biotikus kontroll mintában a sejtszám közel állandó volt (ún. stacioner szakasz). A vas nanorészecskék adagolásának (az ábrán nyíllal jelölve) hatására kezdetben mindegyik mikrokozmoszban 
lecsökkent az élő, tenyészhető sejtek száma, majd ezt követően sejtszám növekedést figyeltünk meg.

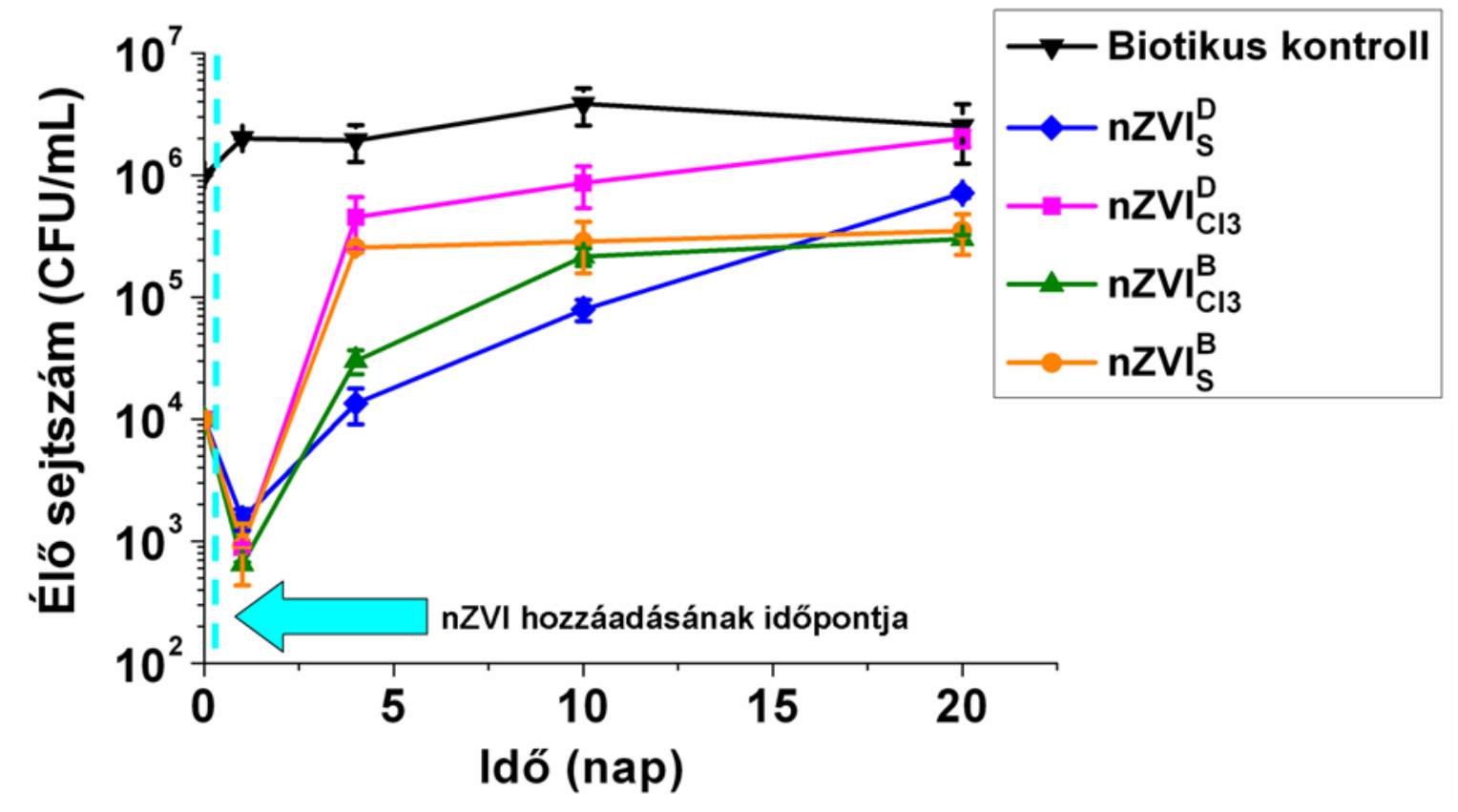

\subsection{1. ábra. Az anaerob tenyészthető sejtek számának változása $0,1 \mathrm{~g} / \mathrm{L}$-es koncentrációban adagolt különböző típusú nanovas hatására.}

A nyíl a nanovas adagolás időpontját jelöli.

A nátrium-borohidriddel redukált vas minták esetében a baktériumok hamarabb elérték a stacioner szakaszt, az élő csíraszám a 10. naptól kezdve állandósult a kontroll mintához képest egy alacsonyabb értéken. Ezzel szemben a nátrium-ditionittal redukált nanovasas kezelés hatására a kezdeti sejtszám csökkenés után sejtszám növekedést figyeltünk meg, amely a 20. nap körül már elérte a kontroll minta sejtszámának értékét.

Megállapíthatjuk tehát, hogy a nanovasas kezelés kezdetben drasztikus sejtszám csökkenést eredményez, majd az új környezethez alkalmazkodás (adaptálódás) után mindkét típusú nanovas adagolása esetén megindul a túlélö baktériumok sejtszámának növekedése bár a nátrium-borohidrides mintáknál kisebb mértékben -, ami egy idő után beáll egy konstans értékre.

Megjegyzendő, hogy ez a módszer nem alkalmazható a nem tenyészthető baktériumok kimutatására, így a biodegradációban résztvevő Dehalococcoides, metanogén vagy szulfátredukáló baktériumok számának meghatározására, ezért ezen közösségek arányának változását génspecifikus kvantitatív PCR-rel követtük nyomon (lásd később 5.2.1.4. fejezet) a kísérlet során. 


\subsubsection{Biomassza mennyiség}

A DNS koncentráció információt ad a mikrokozmoszban lévő összes biomassza mennyiségéről, így a tenyészthető és nem tenyészthető baktériumok mennyiségéről is. Az 5.12. ábra mutatja a különböző típusú nanovas adagolás mellett megfigyelt összes DNS koncentráció változásokat a mikrokozmosz rendszerekben.

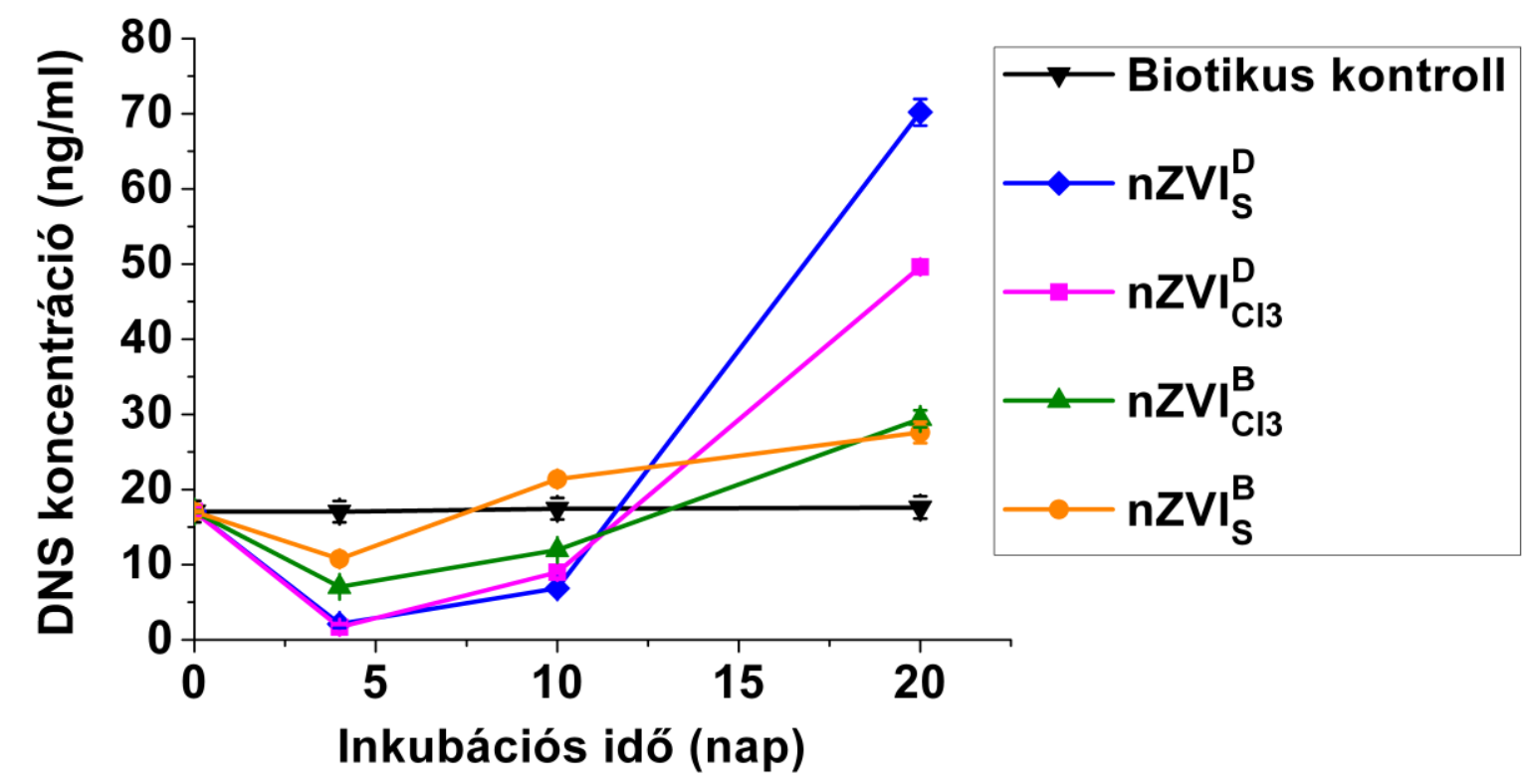

\subsection{2. ábra A mikrokozmosz rendszerek DNS koncentrációjának változása a különböző típusú nanovas adagolás hatására}

Az adagolás nélküli biotikus kontroll esetében az idő előrehaladtával a vártnak megfelelően, nem tapasztaltunk változást a kiindulási DNS koncentrációhoz képest illetve a tenyészthető baktériumok számában.

Az első mintavételnél, tehát 4 nappal a nulla vegyértékű vas nanorészecskék adagolása után, mikrobiális biomassza csökkenést figyeltünk meg mindegyik kezelt minta esetében. Ez a csökkenés valószínüleg a vas nanorészecskék toxikus hatásának köszönhető, ahogy azt már korábban mások is bemutatták ${ }^{93}$. A 10. mintavételi naptól a biomassza mennyiségének a növekedése volt jellemző mind a négy kezelt mintában. A 20. mintavételi napon pedig jól látható, hogy mindegyik kezelt minta túlnőtte a biotikus kontrollt. Érdekes módon a nátrium-ditionittal redukált vas nanorészecskék alkalmazása esetében figyeltük meg a legnagyobb DNS koncentráció növekedést, a nátrium-borohidriddel redukált vas részecskék adagolása kisebb mértékü biomassza növekedést eredményezett. Xiu és munkatársai hasonló tendenciát figyeltek meg a kísérleteik során: a nanovas adagolás kezdetben gátolta a 
baktériumok növekedését, de a kezdeti toxikus hatás után a környezethez adaptálódott mikroflóra alakult ki, majd növekedésnek indult ${ }^{93}$.

\subsubsection{Eubaktérium összetétel (DGGE vizsgálatok)}

A DGGE módszerrel nyomon követhető a bakteriális közösség diverzitás változása a különböző adalékanyagok hatására. A nested PCR során a 16S rDNS (16S riboszómális RNS-t kódoló gén) variábilis V3 régióját amplifikáltuk eubakteriális primerek segítségével. A vizsgálattal arról próbáltunk információt kapni, hogy milyen a nem kezelt, kontroll mikrokozmosz közösség komplexitása, valamint arról, hogy ez miként módosult a különböző vas nanorészecskés kezelés hatására. A 20. napi, 40-60\%-os denaturáló koncentrációjú DGGE gélről készült felvételen (5.13. ábra) látható, hogy a megfigyelt csíkok (band-ek) száma nagyon hasonló volt mindegyik sávban (line). Kis eltéréseket figyeltünk meg a csíkok intenzitásában a vas nanorészecskék szintézise során alkalmazott redukálószer függvényében, tehát a kezelés után kis mértékben megváltozott a bakteriális közösség diverzitása. A nátrium-borohidriddel redukált vas nanorészecskék $\left(\mathrm{nZVI}_{\mathrm{Cl} 3}{ }^{\mathrm{B}}\right.$ és nZVI ${ }_{\mathrm{S}}{ }^{\mathrm{B}}$ ) adagolása esetén a minták DGGE profilján látható csíkok intenzitása és száma hasonló eloszlást mutatott a kontroll mintában megfigyeltekével. A nátrium-ditionittal előállított vas nanorészecskékkel történő kezelés hatására több csík kierősödését észleletük, amiből néhány eddig alulreprezentált törzs előtérbe kerülésére következtethetünk.

7580859095100

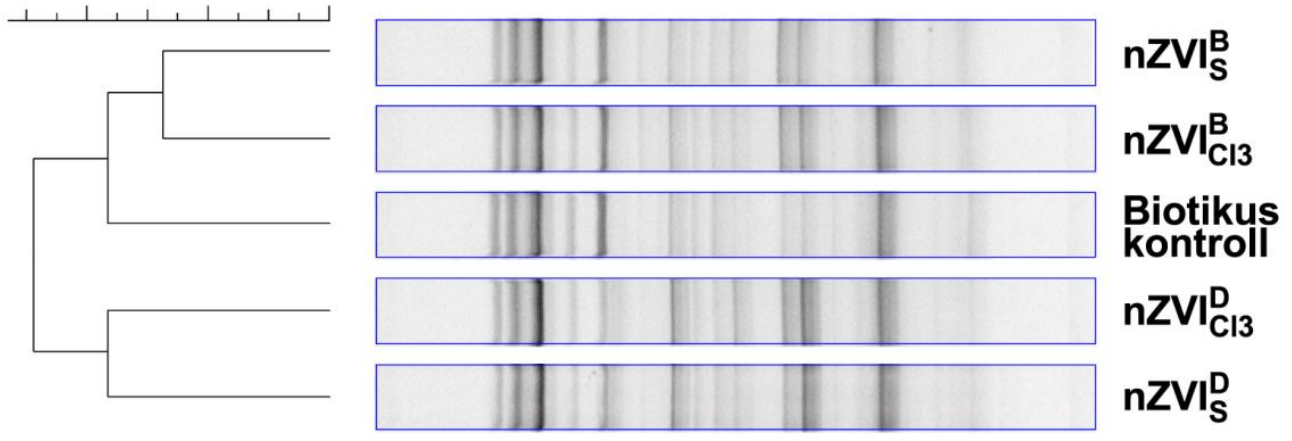

\subsection{3. ábra. A biotikus kontroll és a különböző nanovassal kezelt rendszerek DGGE elemzésének eredménye a 20. napon}




\subsubsection{A biodegradációban részt vevő baktériumok relatív mennyiségének változása}

Ahogy azt 5.2.1.2 fejezetben bemutattuk, a kísérlet során a minták összes baktérium mennyisége kezdetben csökkent, majd nőtt a kezelés hatására függetlenül attól, hogy melyik nanovasat alkalmaztuk.

A biodegradációban fontos szerepet játszó Dehalococcoides törzsek, szulfátredukáló és metanogén baktériumok relatív mennyiségének változását is szerettük volna vizsgálni a különböző vas nanorészecskék adagolásának hatására. A változás meghatározása kvantitatív PCR (qPCR) segítségével történt, az egyes génekre meghatározott értékeket a teljes eubaktérium mennyiséghez viszonyítottuk. A specifikus PCR reakciók során vizsgáltuk a $d h c$, $v c r \mathrm{~A}, t c e \mathrm{~A}, d s r \mathrm{~A}, \operatorname{aps} \mathrm{A}$ és mcrA gének mennyiségének alakulását a mikrokozmosz rendszerekben. Az eredményeket az 5.3. táblázat foglalja össze.

Jól látható, hogy a különböző baktérium nemzetségeket és enzimeket kódoló gének relatív mennyiségének változása erősen függ a vas nanorészecskék szintézise során alkalmazott redukálószertől. Kivétel ez alól a Dehalococcoides törzsek arányának változása. Ebben az esetben azt tapasztaltuk, hogy függetlenül attól, hogy melyik vas nanorészecskét adagoltuk, a Dehalococcoides törzsek relatív aránya csökkent. Tehát a Dehalococcoides törzsek mennyiségének relatív változása független volt a vas nanorészecskék előállítási körülményeitől, azaz a szintézis során felhasznált kiindulási vas-sóktól és redukálószerektől. Azonban a reduktív dehalogenáz génnel (tceA és $v c r A$ ) rendelkező Dehalococcoides törzsek mennyisége nem csökkent olyan mértékben, mint a teljes Dehalococcoides populáció, tehát mindegyik típusú vas nanorészecske kevésbé gátolta azokat a Dehalococcoides törzseket, amik a reduktív deklorinációért felelősek. A kezdeti toxikus hatás után kialakult átrendeződés után, a 20. napon megfigyelhető volt, hogy a reduktív dehalogenáz géneket tartalmazó Dehalococcoides törzsek mennyisége visszaállt a biotikus kontroll arányainak megfelelően.

A szulfátredukáló baktériumok mennyiségének változását a disszimilatórikus szulfit-reduktáz ( $d s r \mathrm{~A})$ és adenozin-foszfoszulfát-reduktáz (aps A) gének, mint filogenetikai markerek alkalmazásával vizsgáltuk. A nátrium-borohidriddel előállított nanovassal történő kezelés esetén az ezeket a reduktáz géneket tartalmazó baktériumok populációjában csak kismértékü változás (kisebb növekedés, majd csökkenés) történt. Ugyanakkor a nátrium-ditionittal redukált vas nanorészecskék alkalmazása a szulfátredukáló baktériumok számának növekedését eredményezte, ami arra enged következtetni, hogy ezek a vas nanorészecskék segítik a szulfátredukálók életben maradását és növekedését. 
A metil-koenzim-M reduktáz génnel $(\operatorname{mcr} \mathrm{A})$ rendelkező baktériumok populációjában mind a négy nanovas alkalmazásánál csökkenést figyeltünk meg a 20. nap végére, a csökkenés mértéke kissé nagyobb volt a nátrium-ditionitos minták esetében. Megjegyzendő, hogy a nZVI ${ }_{\mathrm{S}}^{\mathrm{B}}$ mintánál kezdetben nagymértékü növekedést, majd hirtelen lecsökkenést figyeltünk meg. Mivel a kísérletek során a nanovasak hozzáadását követően nem történt szubsztrát adagolás, így a metanogén baktériumok csökkenését a szubsztrát elfogyása is okozhatta.

5.3. táblázat. A biodegradációban résztvevő mikroorganizmusok és a reduktív dehalogenáz gének relatív arányának változása a különböző nanovas adagolás hatására

\begin{tabular}{|c|c|c|c|c|c|c|}
\hline & $\begin{array}{c}\text { Inkubációs } \\
\text { idő (nap) }\end{array}$ & $\begin{array}{l}\text { Biotikus } \\
\text { kontroll }\end{array}$ & $\mathrm{nZVI}_{\mathbf{S}}{ }^{\mathrm{D}}$ & $n Z V I_{C 13}{ }^{D}$ & $n Z V I_{C l 3}{ }^{B}$ & $\mathrm{nZVI}_{\mathrm{S}}{ }^{\mathrm{B}}$ \\
\hline \multirow{3}{*}{$\begin{array}{l}\text { Dehalococcoides } 16 \mathrm{~S} \text { gén } \\
\% \text {-os aránya az } \\
\text { eubaktérium } 16 \mathrm{~S} \text { gén } \\
\text { mennyiséghez } \\
\text { (dhc gén/eubaktérium) }\end{array}$} & 4 & 8,1 & 5,1 & 4,0 & 7,0 & 8,3 \\
\hline & 10 & 7,3 & 2,3 & 2,4 & 4,8 & 5,8 \\
\hline & 20 & 6,9 & 2,0 & 2,0 & 3,2 & 5,0 \\
\hline \multirow{3}{*}{$\begin{array}{l}\text { vinil-klorid reduktáz gén } \\
\% \text {-os aránya az } \\
\text { eubaktérium } 16 \mathrm{~S} \text { gén } \\
\text { mennyiséghez } \\
\text { (vcrA gén/eubaktérium) }\end{array}$} & 4 & 21,0 & 8,0 & 5,5 & 23,0 & 29,0 \\
\hline & 10 & 20,2 & 15,3 & 12,6 & 14,1 & 19,7 \\
\hline & 20 & 18,9 & 12,5 & 13,3 & 12,6 & 18,4 \\
\hline \multirow{3}{*}{$\begin{array}{l}\text { triklóretilén reduktáz gén } \\
\% \text {-os aránya az } \\
\text { eubaktérium } 16 \mathrm{~S} \text { gén } \\
\text { mennyiséghez } \\
\text { (tceA gén/eubaktérium) }\end{array}$} & 4 & 12,8 & 6,7 & 5,7 & 16,0 & 17,0 \\
\hline & 10 & 12,7 & 11,9 & 11,0 & 15,6 & 19,0 \\
\hline & 20 & 12,6 & 11,8 & 11,8 & 15,7 & 16,4 \\
\hline \multirow{3}{*}{$\begin{array}{l}\text { disszmilatórikus szulfit- } \\
\text { reduktáz gén \%-os aránya } \\
\text { az eubaktérium } 16 \mathrm{~S} \text { gén } \\
\text { mennyiséghez } \\
\text { (dsrA gén/eubaktérium) }\end{array}$} & 4 & 4,8 & 11,2 & 17,2 & 4,6 & 5,1 \\
\hline & 10 & 4,9 & 26,9 & 26,5 & 1,3 & 8,9 \\
\hline & 20 & 4,7 & 10,0 & 12,8 & 1,2 & 1,5 \\
\hline \multirow{3}{*}{$\begin{array}{l}\text { adenozin-foszfoszulfát- } \\
\text { reduktáz gén\%-os aránya } \\
\text { az eubaktérium } 16 \mathrm{~S} \text { gén } \\
\text { mennyiséghez } \\
\text { (apsA gén/eubaktérium) }\end{array}$} & 4 & 4,5 & 19,3 & 35,5 & 9,3 & 9,9 \\
\hline & 10 & 5,1 & 36,0 & 40,9 & 7,2 & 13,5 \\
\hline & 20 & 4,6 & 9,7 & 23,6 & 3,0 & 3,4 \\
\hline \multirow{3}{*}{$\begin{array}{l}\text { metil-koenzim-M reduktáz } \\
\text { enzim gén \%-os az } \\
\text { eubaktérium } 16 \mathrm{~S} \text { gén } \\
\text { mennyiséghez } \\
\text { ( } \mathrm{mcr} \text { A gén/eunbaktérium) }\end{array}$} & 4 & 37,4 & 36,9 & 34,8 & 34,9 & 56,6 \\
\hline & 10 & 36,5 & 18,8 & 16,6 & 37,6 & 46,0 \\
\hline & 20 & 37,2 & 7,6 & 9,1 & 16,4 & 15,4 \\
\hline
\end{tabular}

A vas nanorészecskék anaerob korroziója során keletkező hidrogéngáz (5.1.1.3, 5.1.1.4 és 5.1.1.5 fejezet) a biodegradáló mikroorganizmusok számára elektrondonorként 
szolgálhat. Ha a kémiai nanovas általi lebontás és a mikrobiológiai deklorináció folyamata szinergikus, akkor a vas nanorészecskék képesek lebontani a szennyezők nagy részét, majd a vas által kialakult kedvező reduktív környezetben a maradék klórozott etilének lebontását a deklorináló baktériumok végzik.

Kapott eredményeink csak részben korrelálnak a szakirodalomban fellelhető adatokkal. Számos publikációban kimutatták, hogy a vas nanorészecskék elektrondonorként serkenthetik a metántermelődést és a szulfátredukálás folyamatát. További vizsgálatok szükségesek az általunk vizsgált vas nanorészecskék metanogenezist gátló folyamatának pontos megismeréséhez.

\subsubsection{Nanovasak hatása a kémiai összetételre}

\subsubsection{Vas ionok koncentrációja}

Az előző mérések alapján elmondhatjuk, hogy a vas nanorészecskék a kezelés során, kezdetben gátló hatást fejtenek ki a talajbaktériumok populációjára, ugyanakkor meg kell jegyeznünk, hogy a vas esszenciális tápanyagként szolgál számos baktérium számára. Központi szerepet játszik a sejtnövekedésben, részt vesz a DNS szintézisben, enzimek kofaktoraként betöltött szerepe messze a legfontosabbá teszi a mikrotápelemeknek is nevezett fémionok között. Vas hiányában megszünhet az egyes oxidoreduktáz enzimekben nélkülözhetetlen kofaktorok, a citokrómok bioszintézise. A vas eddig említett élettani szerepein kívül alapvető szerepet játszik számos biokémiai reakcióban, mint például a légzés, fotoszintetikus transzport, nitrát szintézis vagy nitrogén fixálás. Ezért valószínüsíthető, hogy a betáplált nulla vegyértékű vas nanorészecskékböl származó vas-ionokat számos baktérium hasznosíthatja anyagcsere folyamatai során ${ }^{219}$, ezt azonban nem vizsgáltuk a munkánk során.

Azonban fontosnak találtuk az egyes mikrokozmoszok vas-ion tartalmának meghatározását, ezért a 20. napon vett mintákon ICP-MS méréseket végeztünk. Az 5.4. táblázat adatai alapján elmondható, hogy a nem kezelt, biotikus minta esetében alacsony oldott vastartalom figyelhető meg $(0,19 \pm 0,10 \mathrm{mg} / \mathrm{L})$.

A különböző nanovassal kezelt mikrokozmoszok esetében az oldott vas ionok koncentrációja a nátrium-ditionittal redukált vas mintáknál kissé alacsonyabb volt $\left(\mathrm{nZVI}_{\mathrm{S}}{ }^{\mathrm{D}}\right.$ : $0,56 \pm 0,10 \mathrm{mg} / \mathrm{L}$ és $\left.\mathrm{nZVI}_{\mathrm{Cl}}{ }^{\mathrm{D}}: 0,69 \pm 0,12 \mathrm{mg} / \mathrm{L}\right)$, mint a nátrium-borohidriddel előállított nanovas minták esetében (nZVI ${ }_{\mathrm{S}}{ }^{\mathrm{B}}: 0,82 \pm 0,10 \mathrm{mg} / \mathrm{L}$ és $\mathrm{nZVI}_{\mathrm{Cl}}{ }^{\mathrm{B}}: 0,91 \pm 0,14 \mathrm{mg} / \mathrm{L}$ ). Tehát mindegyik mikrokozmosz modellben a vas ionok lassú oldódása következett be, ami kedvező 
hatással lehet a vas redukálásából energiát szerző baktériumok növekedésére ${ }^{219}$, azonban ezt részletesen nem vizsgáltuk.

5.4. táblázat. A mikrokozmoszokban mért vas ionok mennyisége

\begin{tabular}{cccccc}
\hline & $\begin{array}{c}\text { Biotikus } \\
\text { kontroll }\end{array}$ & $\mathbf{n Z V I}_{\mathbf{S}}{ }^{\mathbf{D}}$ & $\mathbf{n Z V I}_{\mathbf{C l 3}}{ }^{\mathbf{D}}$ & $\mathbf{n Z V I}_{\mathbf{C l 3}}{ }^{\mathbf{B}}$ & $\mathbf{n Z V I}_{\mathbf{S}}^{\mathbf{B}}$ \\
\hline $\begin{array}{c}\text { Vas ionok } \\
\text { koncentrációja (mg/L) }\end{array}$ & $0,19 \pm 0,10$ & $0,56 \pm 0,10$ & $0,69 \pm 0,12$ & $0,82 \pm 0,10$ & $0,91 \pm 0,14$ \\
\hline
\end{tabular}

\subsubsection{Reduktív deklorináció a mikrokozmosz rendszerekben a különböző nanovas adagolás mellett}

A mikrokozmosz rendszerekben a kiindulási modellszennyező vegyületként használt triklóretilén és származékainak koncentráció változását gázkromatográfiás mérésekkel követtük nyomon. A négy vas nanorészecske alkalmazásakor eltérő deklorináló profilokat figyeltünk meg (5.14. ábra és 5.15. ábra). A triklóretilén bontása megvalósulhat kémiai útvonalon, a nulla vegyértékü vas nanorészecskék által, vagy mikrobiológiai úton, a deklorináló szervezetek segítségével. A vas által indukált kémiai útvonalon végtermékként a $\beta$-eliminációból acetilént, a hidrogenolizisből pedig etilént kapunk. A klórozott köztitermékek megjelenése a biológiai dehalogenizációra utal (2.5. ábra).

A biotikus kontroll esetében, nanovas részecskék nélkül, a triklóretilén konszekutiv reakciókban etilénné alakult. 0,1 g/L nanovas tartalom mellett a mikrokozmoszok cisz-diklóretilén és vinil-klorid koncentrációja nem változott. Ezek az eredmények alátámasztják az eddigi méréseinket, miszerint a nanovas már ebben az alkalmazott koncentrációban, a szintézis során felhasznált redukálószertől függetlenül, gátló hatással van a biológiai deklorinációra.

A legnagyobb különbségeket a mikrokozmoszok gázterének összetételében tapasztaltuk (5.15. ábra). Négy nap inkubáció után csak a nátrium-borohidriddel redukált vas nanorészecskék esetén figyeltünk meg etán- és acetiléngáz fejlődést - ami a másik két nanovas alkalmazásánál egyáltalán nem jelent meg -, továbbá itt a TCE redukciója során is jobb eredményeket kaptunk. Ebböl arra következtettünk, hogy a borohidrides minták esetén a kémiai lebontás dominált, a biológia deklorináló aktivitás lecsökkent. Emellett a nátrium-borohidriddel redukált minták jelenléte jelentősen serkentette a metanogenezist:

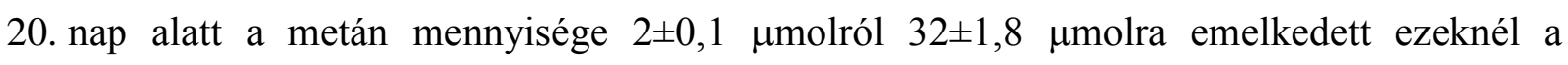
mintáknál, míg a biotikus kontroll esetében mindössze 6-9 $\mu$ mol között maradt. 

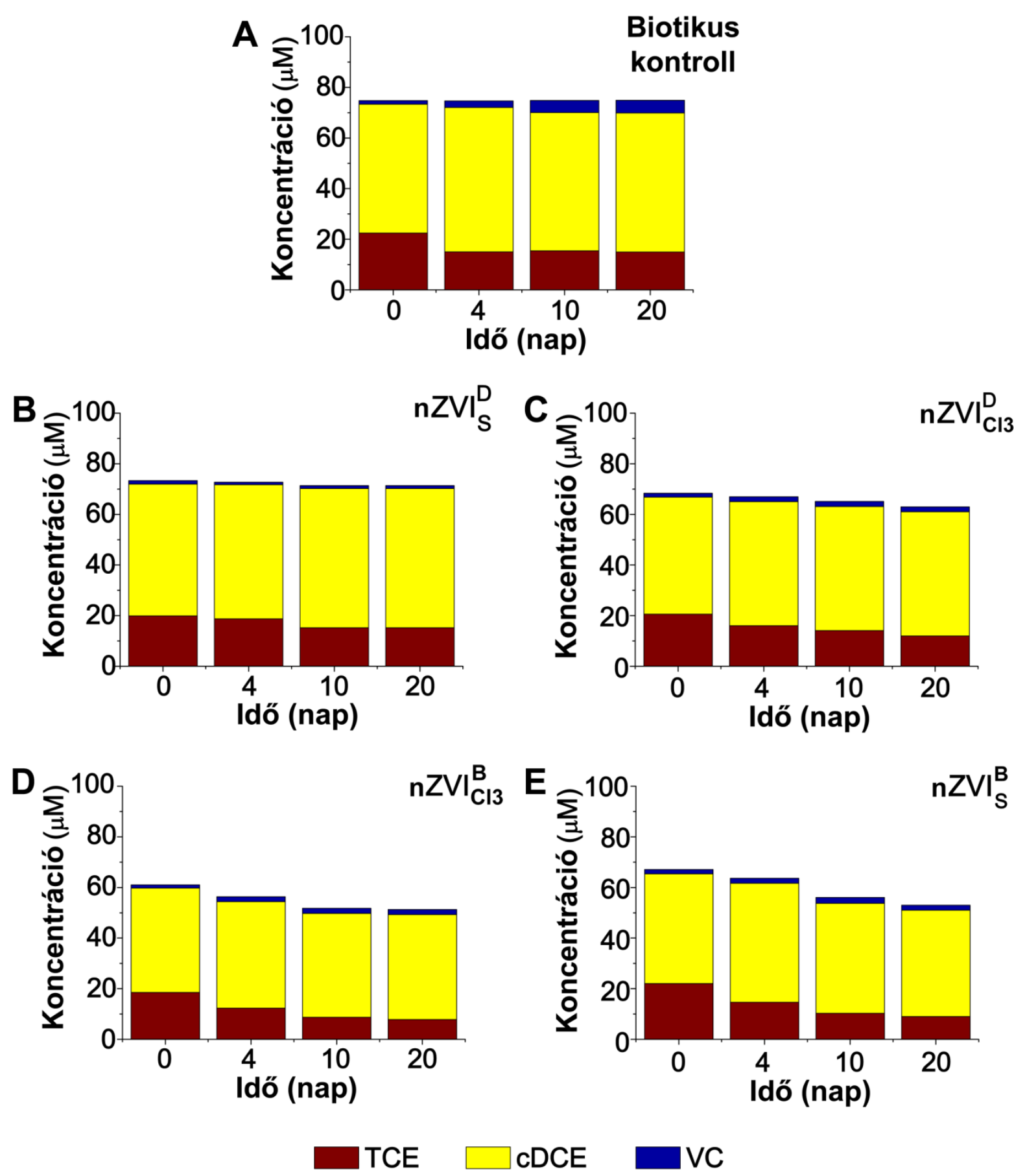

5.14. ábra. A TCE és cDCE kémiai és mikrobiológiai reakciója $0,1 \mathrm{~g} / \mathrm{L}$ nanovas szuszpenziók (B-E) adagolása mellett. A biotikus kontroll (A) csak a deklorináló baktériumokat tartalmazza. 
A

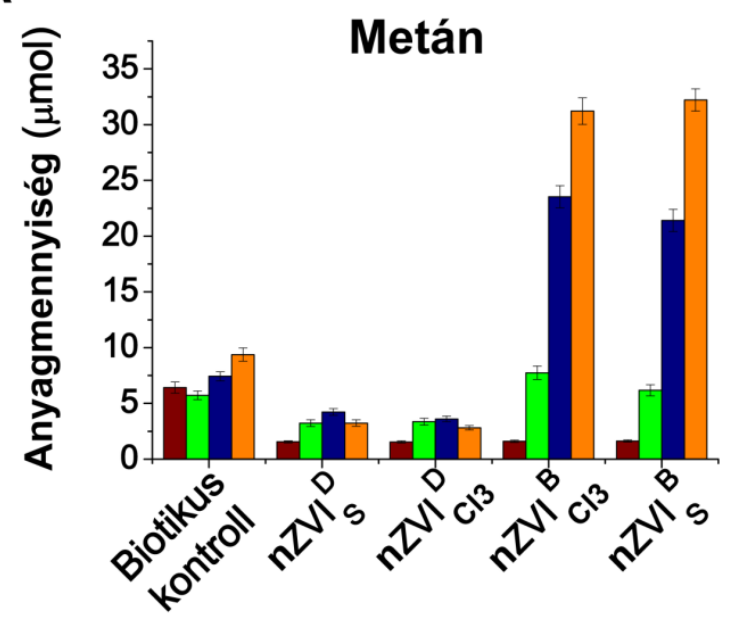

C

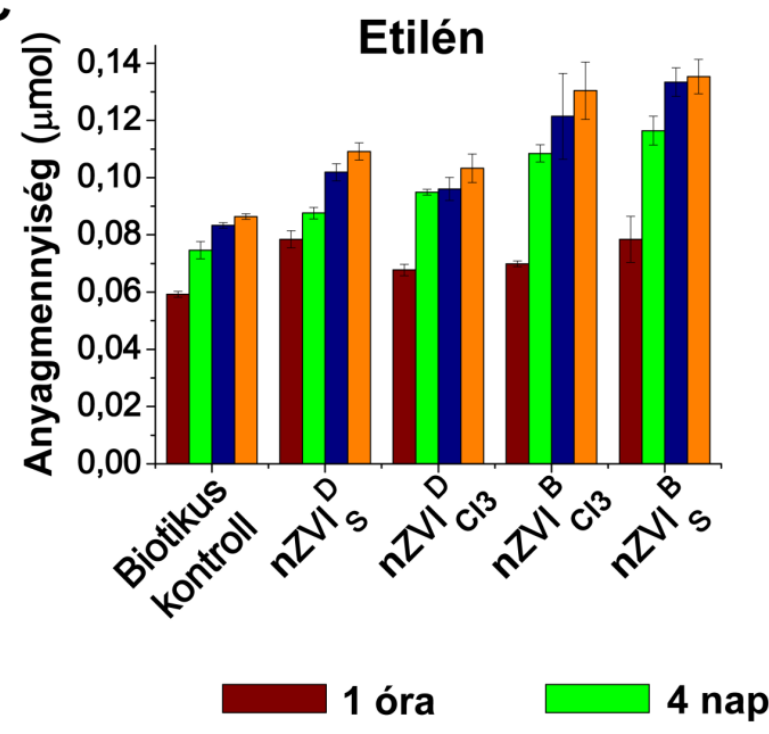

B

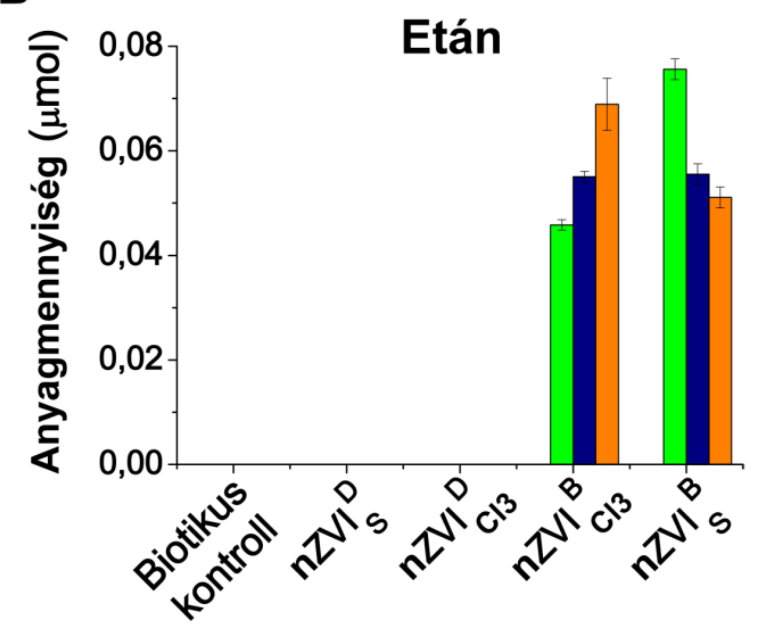

D

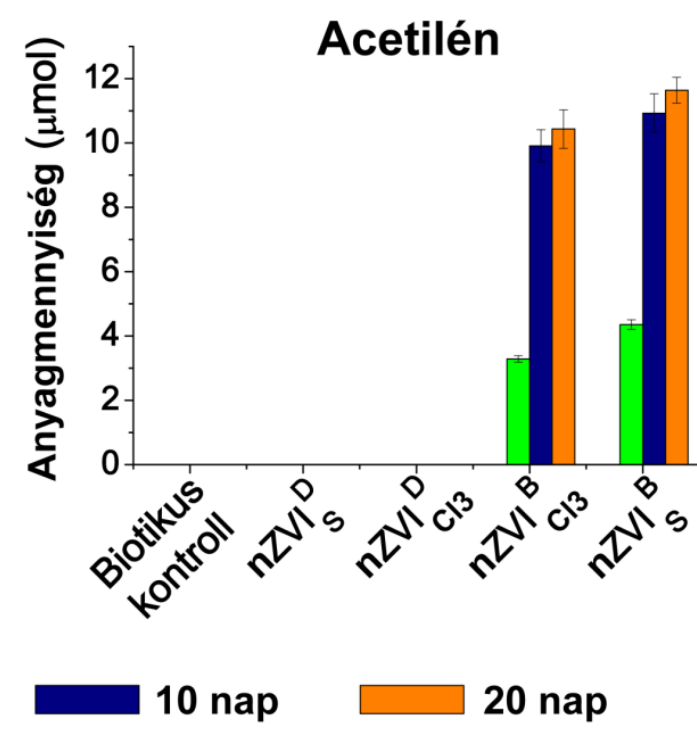

\subsection{5. ábra. A deklorináló baktériumokat tartalmazó mikrokozmosz rendszerek} kumulatív metán (A), etán (B), etilén (C) és acetilén (D) hozama 0,1 g/L különböző típusú nanovas adagolása mellett

Összegezve, megfigyeléseink alapján elmondható, hogy a környezeti kármentesítés során a remediáció fokozása érdekében nagyon fontos a megfelelő vas nanorészecske körültekintő kiválasztása, mivel a szintézis során alkalmazott prekurzorok és redukálószerek jelentősen befolyásolják a kialakult nanorészecskék morfológiája és hatékonysága mellett az anaerob baktériumokra és a deklorináló folyamatokra gyakorolt hatását is.

Eredményeink összefüggnek a szakirodalmi adatokkal és a fellelhető terepi tesztek eredményeivel, melyek szerint a nanovas alkalmazása mellett a kezdeti toxicitás után az adaptálódó deklorináló mikroorganizmusok segítették a szénhidrogének lebontását ${ }^{89,93,220}$. Mindez kiválóan megalapozza az előállított vas nanorészecskék alkalmazhatóságát későbbi terepi tesztek során, lehetővé téve egy kombinált kémiai-biológiai kezelés kidolgozását. 


\subsection{Növényi kivonatokkal előállított ezüst nanorészecskék kémiai és biológiai aktivitásának összehasonlító vizsgálata}

A nanorészecskék mindennapi életben való biztonságos használatához nagyon fontos felmérnünk, hogy az egyes részecskék jellemző tulajdonságait, életszerü környezetben való viselkedését milyen tényezők határozzák meg. Az előző fejezetek eredményei alapján elmondható, hogy a vas nanorészecskék szintézise során alkalmazott kiindulási vas-sók, redukálószerek és egyéb stabilizáló anyagok jelentősen befolyásolják a kapott nanorészecskék aktivitását (hatékonyságát) és morfológiáját, illetve biológiai aktivitását. A redukálószerek befolyásoló hatását egy másik, napjainkban széleskörüen alkalmazott nanorészecske előállításában és karakterisztikus tulajdonságainak vizsgálatában folytattuk.

Köszönhetően a széles körü alkalmazási lehetőségeiknek az ezüst nanorészecskék előállítása és felhasználása iránti igény egyre nő. Habár az utóbbi években egyre inkább elötérbe kerültek a növényi kivonatokat felhasználó zöld szintézismódszerek, csak kevés tanulmány született az elöállított nanorészecskék komplex (antibakteriális, antifungális, antivirális és citotoxikus) biológiai aktivitásának vizsgálatáról, különös tekintettel a szintézis során alkalmazott különböző növényi kivonatok hatásának függvényében.

Munkánk harmadik részében meg akartuk vizsgálni, hogy az ezüst nanorészecskék szintézise során felhasznált redukálószerek, esetünkben növényi kivonatok milyen hatással vannak a kialakult részecskék karakterisztikus tulajdonságaira és későbbi alkalmazási lehetőségeire. Tanulmányoztuk, hogy a kávéból és zöld teából készült növényi kivonatok mennyire alkalmasak ezüst nanorészecskék zöld módszerrel történő előállítására, illetve hogy a szintetizált anyagok különböző biológiai rendszerekre gyakorolt hatásai között milyen különbségek vannak. Mivel a szakirodalom alapján a kávé és zöld tea kivonatával is állítottak már elő sikeresen nanorészecskéket, így munkánk célja elsősorban nem az volt, hogy megállapítsuk, hogy melyik kivonat alkalmazása kedvezőbb a szintézis során, hanem, hogy feltárjuk az így kialakult nanorészecskék kémiai és biológiai tulajdonságainak esetleges különbözőségét, ami az eltérő redukálószer alkalmazásából ered.

Ezen eltérések kimutatásához kávé és zöld tea kivonatával ezüst nanorészecskéket állítottunk elő, amelyeket átfogó, komplex kémiai és biológiai vizsgálatoknak vetettük alá. 


\subsubsection{A növényi kivonatokkal előállított ezüst nanorészecskék jellemzése}

\subsubsection{Transzmissziós elektronmikroszkópia - morfológia és méret}

A TEM felvételeken jól látható, hogy mind a zöld tea (GT-AgNP), mind a kávé (C-AgNP) kivonattal előállított ezüst nanorészecskék gömbszerünek adódtak. A képek alapján a monodiszperz C-AgNP részecskék jól diszpergáltak voltak, azonban a kávé kivonatból visszamaradt mátrixba ágyazódtak. Ezzel szemben a GT-AgNP részecskék kicsit nagyobb méretủek, csekély polidiszperzitást és kismértékü részecskeaggregációt figyeltünk meg ebben az esetben (5.16. ábra). A TEM képek alapján számolt átlagos részecskeméret a

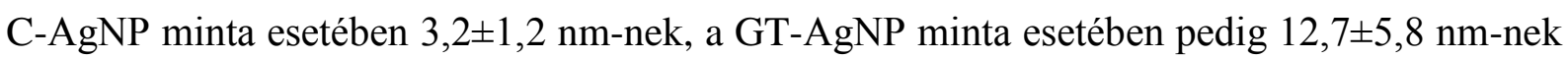
adódott.
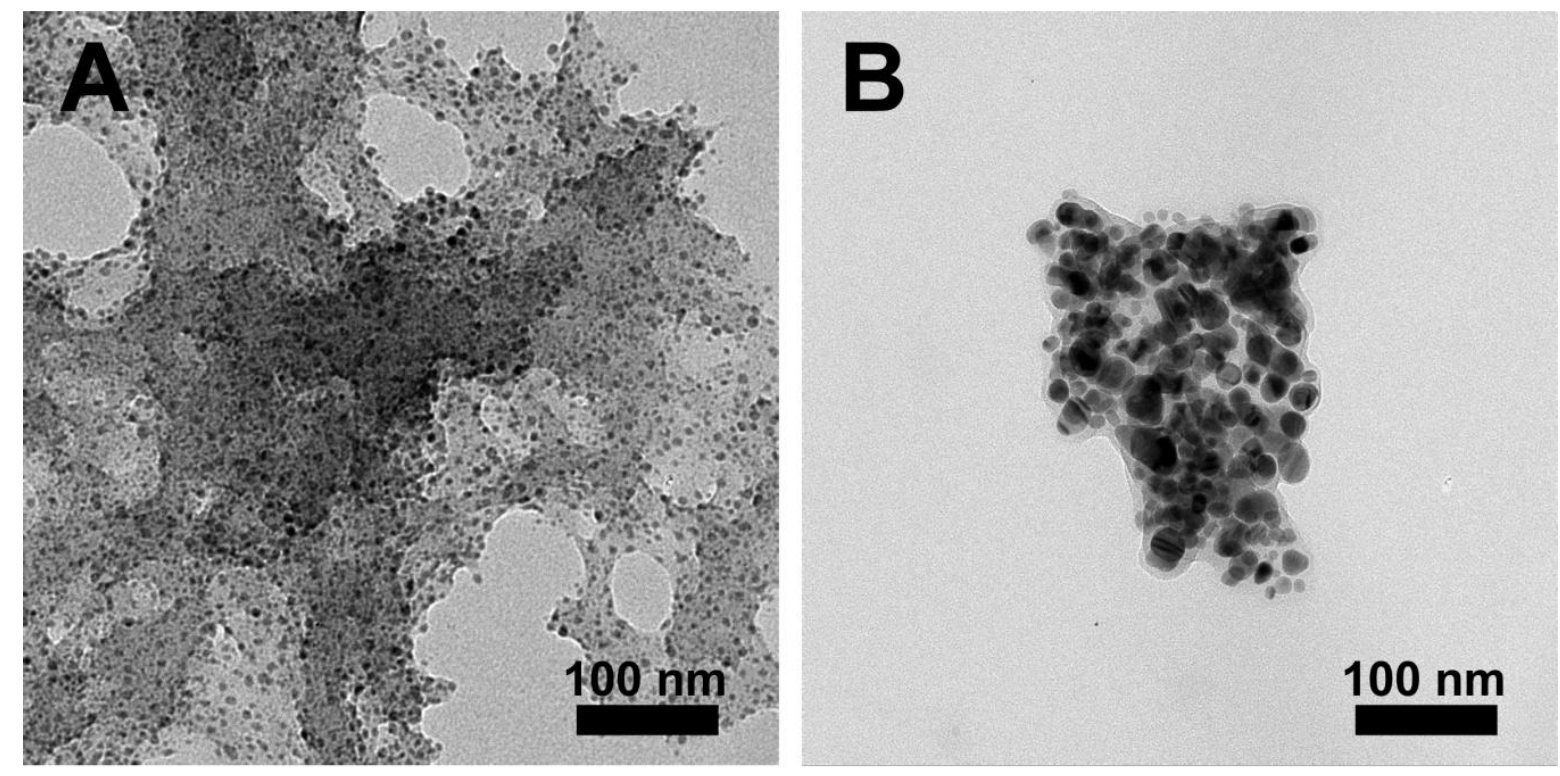

5.16. ábra. A kávé (A) és zöld tea (B) kivonattal előállított ezüst nanorészecskék jellemző TEM felvételei

\subsubsection{Röntgendiffraktometriás vizsgálatok - kristályszerkezet}

A szintetizált nanorészecskék kristályszerkezetét röntgendiffraktometriával (XRD) határoztuk meg (5.17. ábra). Mindkét kivonattal előállított ezüst nanorészecskék XRD mintázatában négy jellemző, éles reflexiót figyelhetünk meg a $38,2^{\circ}, 44,3^{\circ}, 64,4^{\circ}$ és $77,4^{\circ} 2 \Theta$ szögeknél, amelyeket rendre a lapcentrált köbös rendszerben kristályosodó fém ezüst (111), (200), (220) és (311) kristálylapjaihoz tartozó reflexióként azonosítottunk (JCPDS \#87-0717) $)^{210}$. 


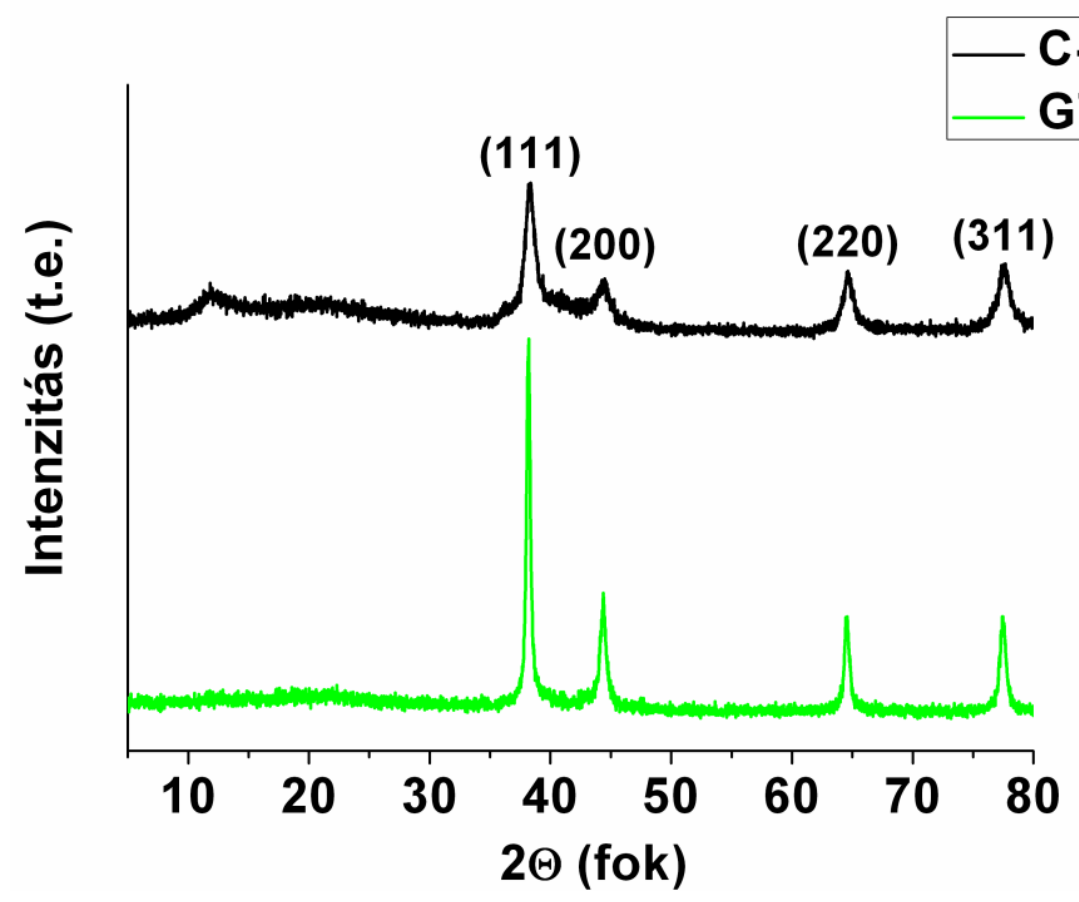

5.17. ábra. A kávé (C-AgNP) és zöld tea (GT-AgNP) kivonattal előállított ezüst nanorészecskék diffraktogramjai

\subsubsection{Dinamikus fényszórás - hidrodinamikai átmérő}

A nanorészecskék hidrodinamikai részecskeátmérőjét DLS készülékkel mértük meg (5.18. ábra). A TEM méréseknél megfigyelt méretbeli különbségeket a DLS mérések során is detektáltuk: jól látható, hogy a C-AgNP minta átlagos mérete 8-20 nm között változott, míg a GT-AgNP minta részecskéinek hidrodinamikai átmérője kissé nagyobbnak adódott, 20 és $50 \mathrm{~nm}$ között volt. Ezenkívül a GT-AgNP mintában megfigyelhető volt egy további csúcs $400 \mathrm{~nm}$ körül, amely a részecskék mérsékelt aggregációjára utalt.

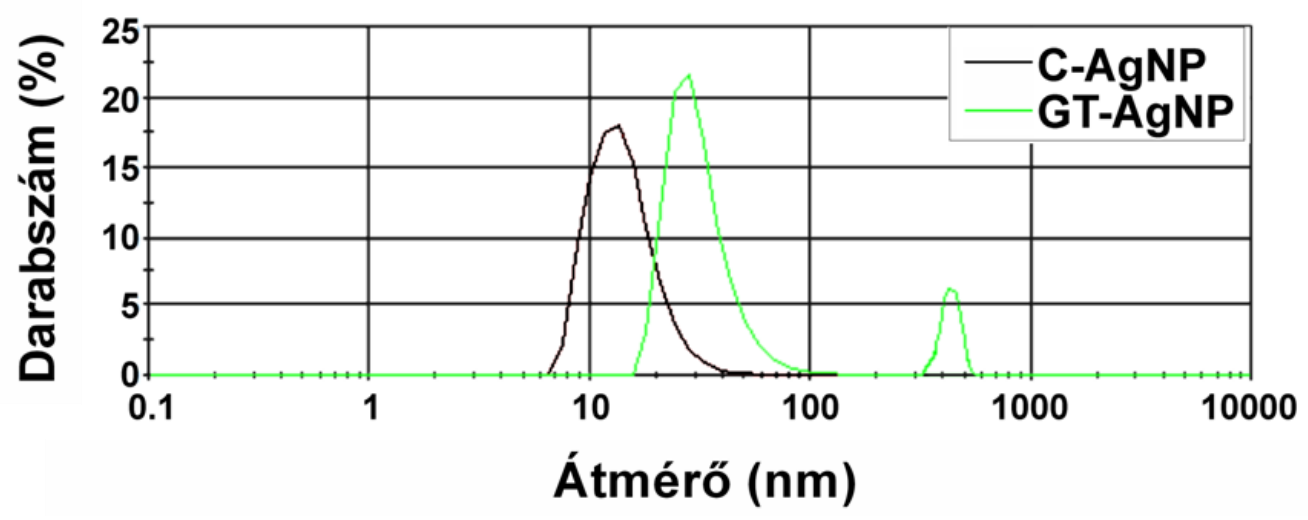

5.18. ábra. A kávé (C-AgNP) és zöld tea (GT-AgNP) kivonattal előállított ezüst nanorészecskék hidrodinamikai átmérőjének eloszlásai 


\subsubsection{Ultraibolya-látható abszorpciós spektrometria - szerkezet}

A kávé és zöld tea kivonatokkal készült AgNP minták UV-VIS spektrumát az 5.19. ábra szemlélteti. Jól látható, hogy mindkét ezüst nanorészecske rendelkezett felületi plazmon rezonancia maximummal, melyek értéke $\lambda_{\max }=496 \mathrm{~nm}$ volt C-AgNP esetén, míg $\lambda_{\max }=456 \mathrm{~nm}$ GT-AgNP esetén. Ez az ezüstre jellemző karakterisztikus elnyelésbeli eltérés eredhet a részecskék TEM és DLS vizsgálatokkal igazolt méretbeli különbségéböl ${ }^{162}$.

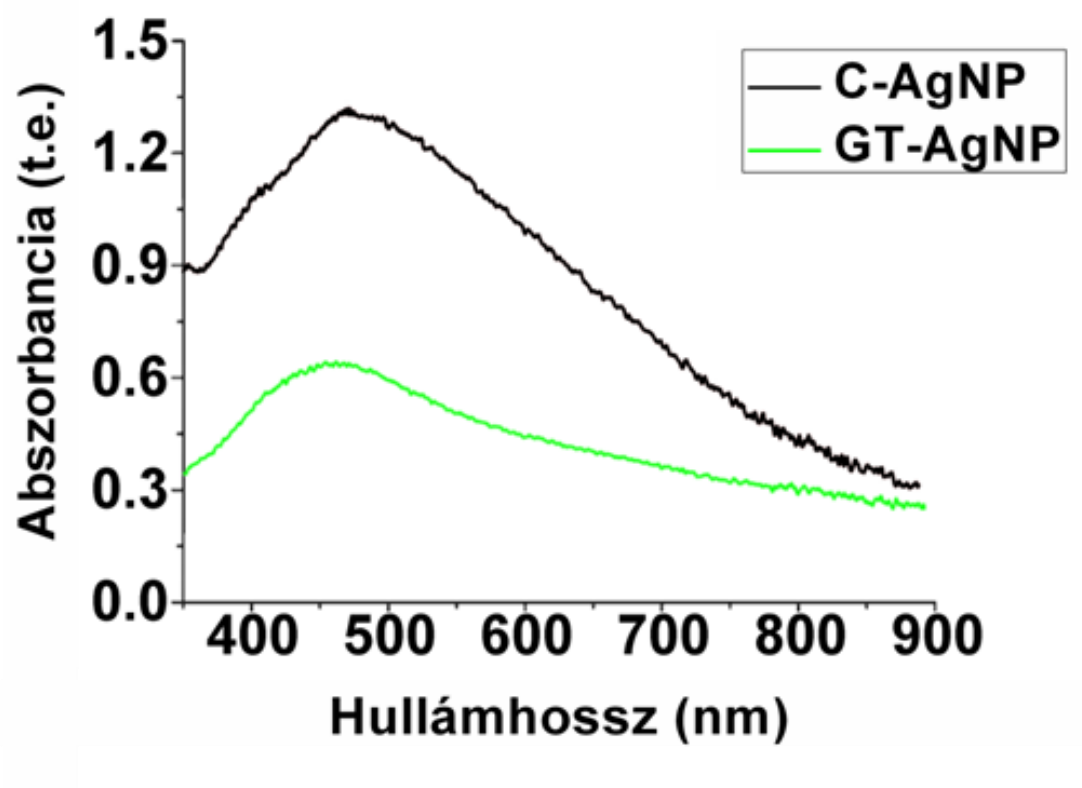

5.19. ábra. A kávé és zöld teával előállított ezüst nanorészecskék UV-VIS spektrumai

\subsubsection{Infravörös spektroszkópia}

Hogy pontosabb képet kapjunk a részecskék tulajdonságait is meghatározó redukálószerek befolyásoló hatásáról, a növényi kivonatok (kávé-C, zöld tea-GT) és a segítségükkel előállított AgNP minták kémiai összetevőinek funkciós csoportjait infravörös spektroszkópiával vizsgáltuk (5.20. ábra).

A spektrumokon $3400 \mathrm{~cm}^{-1}$-nél található intenzív széles sáv elsősorban a hidroxil csoportokra jellemző O-H vegyértékrezgéshez tartozik, ami alapján mindegyik minta tartalmazott alkoholos, fenolos és karboxil funkciós csoportokat; valamint ennek a sávnak az intenzitásához járul hozzá a primer és szekunder aminok és amidok N-H vegyértékrezgése is. 


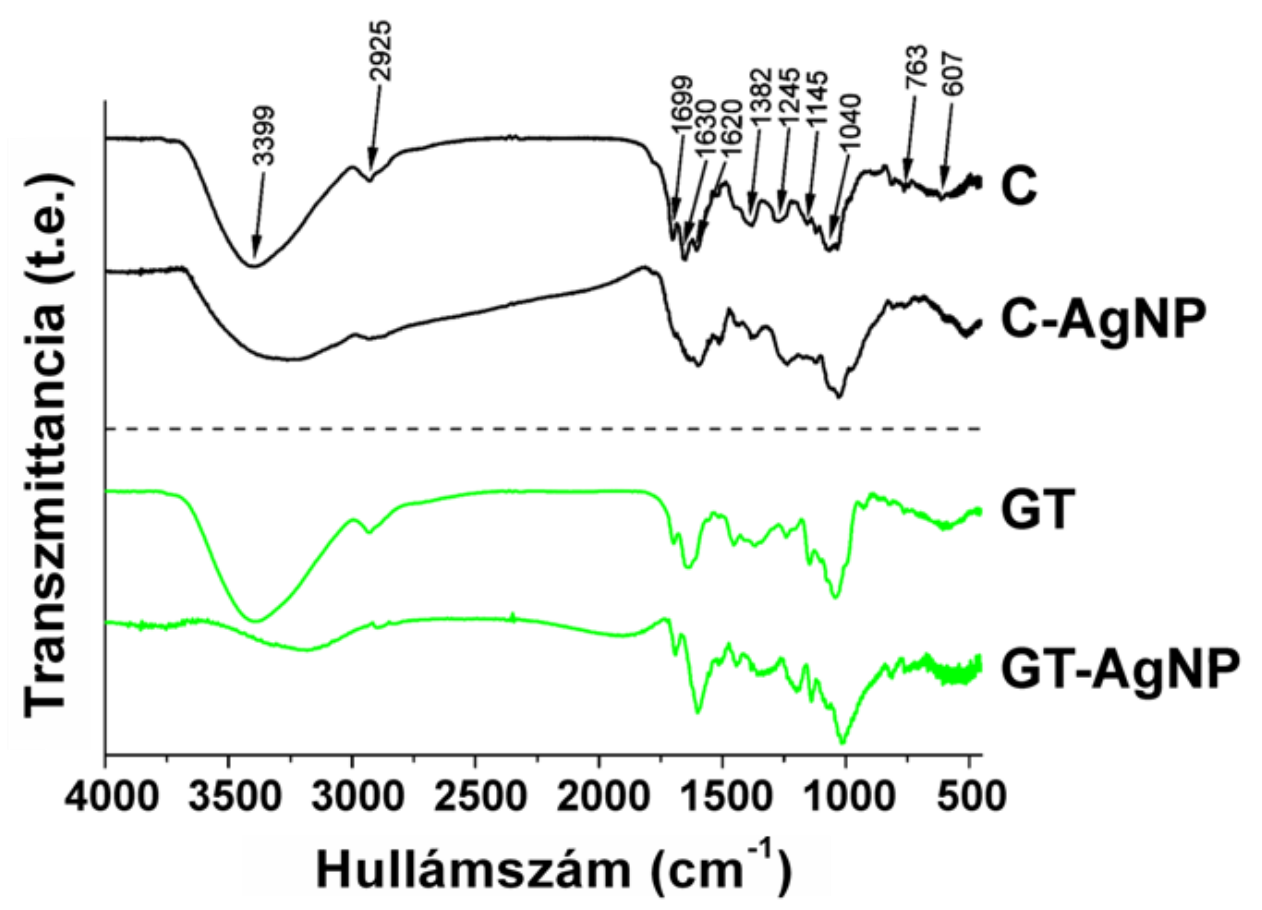

5.20. ábra. A növényi kivonatok (kávé-C, zöld tea-GT) és a segítségükkel előállított AgNP minták FT-IR spektrumai

Ez a sáv ugyancsak köthetö a nem disszociált kötött vízmolekulákhoz is, amik jelenléte egyértelműen látszik a deformációs rezgéshez tartozó $1620 \mathrm{~cm}^{-1}$-nél megfigyelhető sávból. Az $1145 \mathrm{~cm}^{-1}$-nél látható sáv a primer és szekunder aromás aminok C-N vegyértékrezgésének tudható be, a $900-600 \mathrm{~cm}^{-1}$ közötti sávok pedig a primer és szekunder aminok és amidokhoz tartoznak (- $\mathrm{NH}_{2}$ síkra merőleges deformációs rezgés). A ketonok, aldehidek, kininek és észterek jelenlétére utalnak az 1700-1600 $\mathrm{cm}^{-1}$ közötti sávok, amelyek a karbonil csoportok $\mathrm{C}=\mathrm{O}$ rezgéséből származhatnak. A $2920 \mathrm{~cm}^{-1}$-nél lévő sáv az alkánok $\mathrm{C}-\mathrm{H}$ vegyértékrezgéséhez köthető. $\mathrm{Az} 1630 \mathrm{~cm}^{-1}$ körül található sáv az aromás szerkezetek $\mathrm{C}=\mathrm{C}$ rezgésének tudható be, míg a fenolos csoportok C-O vegyértékrezgésére jellemző sávot láthatunk $1245 \mathrm{~cm}^{-1}$-nél. Az $1040 \mathrm{~cm}^{-1}$-nél lévő másik széles sáv az aromás észterek és a poliszacharidok jele lehet (C-O-C vegyértékrezgés) ${ }^{165}$. A kávé és zöld tea kivonatainkban a karbonil csoportok fehérjék jelenlétére utalnak, míg az -OH funkciós csoportok jelenlétéből arra következtethetünk, hogy a kivonatok fenolos vegyületeket is tartalmaznak.

A FT-IR mérés eredményei alapján arra következtethetünk, hogy a kávé és tea kivonatainkból származó szerves vegyületek megtalálhatóak az elöállított ezüst nanorészecskék felületén (900-1800 $\mathrm{cm}^{-1}$ közötti sávok). Ezen megfigyelésünk összhangban van az irodalomban közölt adatokkal, azaz bizonyos fehérjék, valamint egyéb egyszerüés/vagy makromolekulák képesek a nanorészecskék felületén megkötődni és ezzel stabilizálni, védeni azokat az aggregációtól ${ }^{221}$. 


\subsubsection{A növényi kivonatokkal előállított ezüst nanorészecskék toxicitásának vizsgálata}

\subsubsection{A növényi kivonatokkal előállított ezüst nanorészecskék toxicitásának vizsgálata}

Az elöállított nanorészecskék alkalmazásának egyik feltétele, hogy pontosan ismerjük az élő rendszerekre gyakorolt hatását, esetleges elönyös vagy káros biológiai aktivitását. Munkánk során a kávé és zöld tea kivonatával előállított ezüst nanorészecskék antiproliferatív és citotoxikus hatását humán tumoros HeLa és nem-tumoros NIH/3T3 egér embrionális fibroblaszt sejteken vizsgáltuk.

\subsection{Sejtproliferációs vizsgálat}

Az MTT tesztek alapján megállapítottuk, hogy a GT-AgNP nagyobb mértékben gátolta mindkét sejttípus proliferációját, mint a C-AgNP (5.21. ábra). A számolt $\mathrm{IC}_{50}$ koncentrációértékek alapján a NIH/3T3 egér fibroblaszt sejtek sokkal érzékenyebbnek (GT-AgNP: 5 $\mu \mathrm{g} / \mathrm{mL}, \mathrm{C}-A g N P: ~ 272,14 \pm 0,09 \mu \mathrm{g} / \mathrm{mL}$ ) bizonyultak az ezüst nanorészecskék jelenlétére, mint a HeLa sejtek (GT-AgNP: 14,26 $\pm 0,05 \mu \mathrm{g} / \mathrm{mL}, \mathrm{C}-\mathrm{AgNP}: 655,3 \pm 0,12 \mu \mathrm{g} / \mathrm{mL}$ ). Továbbá elmondhatjuk azt is, hogy mindkét sejtvonal esetén a GT-AgNP körülbelül 50-szer erősebb gátló hatást tanúsított a sejtek proliferációjára mint a C-AgNP.

\subsection{Citotoxicitás}

A zöld úton előállított ezüst nanorészecskék citotoxikus hatását kritályibolya festéssel határoztuk meg (5.21. ábra). A kávé kivonattal szintetizált ezüst nanorészecskék az alkalmazott koncentrációtartományban nem bizonyultak toxikusnak sem a humán, sem az egér sejtek esetében. Ezzel szemben a zöld teával elöállított nanoezüst minták erősen citotoxikus hatást mutattak mind a HeLa, mind a NIH/3T3 sejtek esetén, valamint az utóbbiak érzékenyebbnek bizonyultak a GT-AgNP jelenlétére.

Az eredményeink alapján megállapítható, hogy a zöld teával szintetizált nanoezüst részecskék sokkal nagyobb mértékủ antiproliferatív és citotoxikus hatással rendelkeztek, mint a kávéval előállított ezüst nanorészecskék. 
A

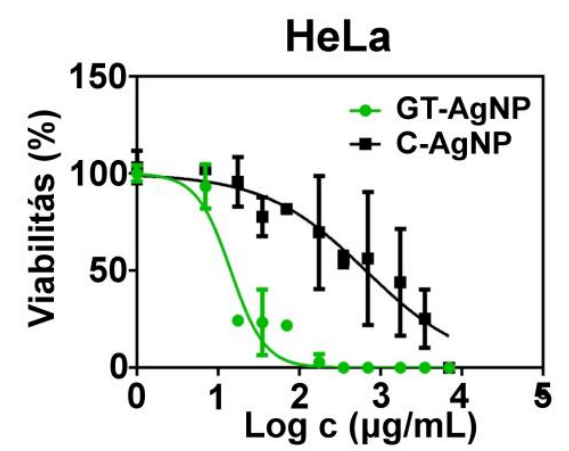

C

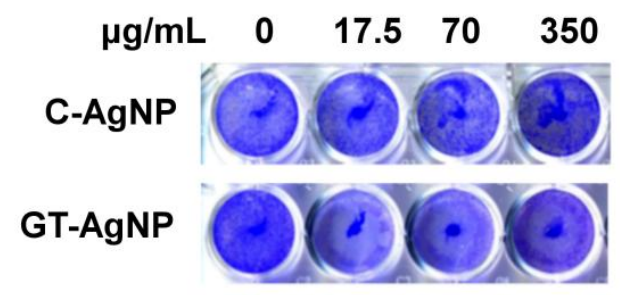

$\mathrm{E}$

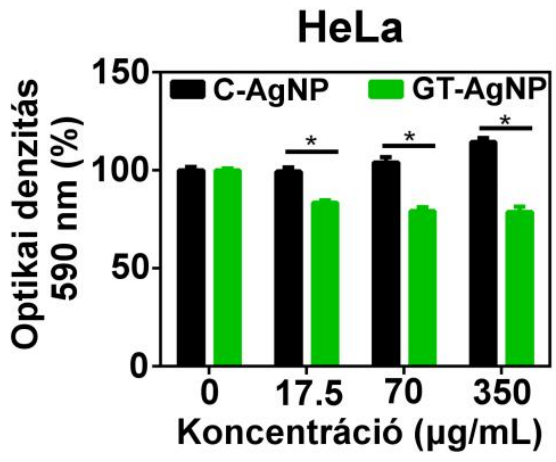

B

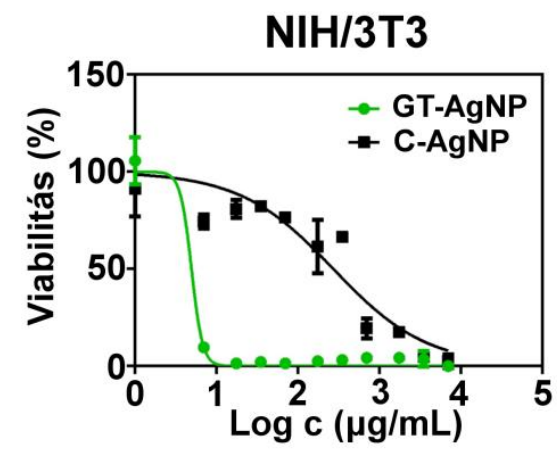

D

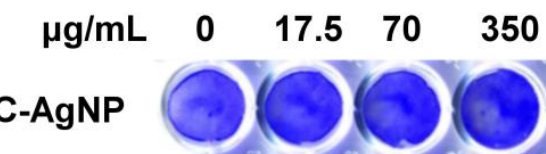

GT-AgNP

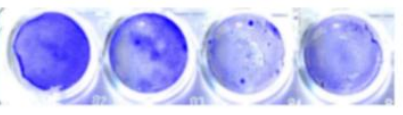

$\mathrm{F}$

NIH/3T3

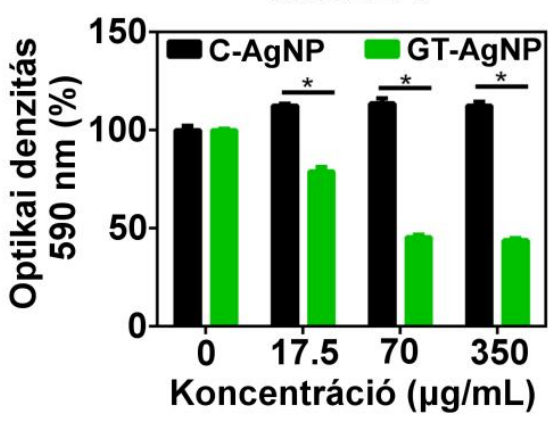

5.21. ábra. A növényi kivonatok segítségével előállított ezüst nanorészecskék antiproliferatív és citotoxikus hatása. A C-AgNP és GT-AgNP-vel való kezelés mindkét sejttípus (humán HeLa-A, egér NIH/3T3 fibroblaszt sejtek-B) proliferációját gátolta. A zöld úton előállított ezüst nanorészecskék citotoxikus hatását kritályibolya festéssel határoztuk

meg (C, D). A kristályibolyát visszaoldottuk, majd a minták abszorbanciáját spektrofotometriásan mértük ( $\mathbf{E}, \mathbf{F})(* \mathrm{P} \leq 0,001$, kétutas ANOVA, a kontroll abszorbanciáját $100 \%$-nak véve).

\subsubsection{Antibakteriális és antifungális hatás}

Vizsgálataink során fel akartuk térképezni, hogy az előállított ezüst nanorészecskék rendelkeznek-e antibakteriális és/vagy antifungális hatással, illetve ha igen, akkor melyik növényi kivonattal előállított nanoezüst tanúsít nagyobb toxikus hatást a kiválasztott mikrobatörzsekkel szemben. Az előállított nanoezüst részecskék antimikrobiális hatását B. cereus var. myocides, M. luteus, E. coli és P. aureuginosa baktériumokon, illetve nem patogén S. cerevisiae, valamint patogén C.parapsilosis, C. albicans és Cr.neoformans élesztőgombákon teszteltük (5.22. ábra). Jól látható, hogy mind a kávé, mind a zöld tea kivonatok segítségével elóállított nanorészecskék hatékonynak bizonyultak a vizsgált 
baktériumtörzsek ellen. A baktériumokhoz hasonlóan a patogén gombafajok ( $C r$. neoformans, C. parapsilosis, C. albicans) is érzékenyek voltak mindkét típusú nanoezüst részecske jelenlétére, amit a körülöttük kialakult széles gátlási zóna jól mutat (5.22. ábra, 5.5. táblázat). Az alkalmazott koncentrációkban egyik nanoezüst részecske sem volt gátló hatással az apatogén $S$. cerevisiae fajra, ebben az esetben nem észleltük gátlási zóna kialakulását (5.22. ábra).

Mivel az agar-diffúziós módszer önmagában nem alkalmas a C-AgNP és GT-AgNP hatékonyságának kvantitatív összehasonlítására, ezért a nanoezüst mintákat különbözö koncentrációban teszteltük $E$. coli és $C r$. neoformans törzseken, miközben meghatároztuk a mikrobák túlélési arányát. A bemutatott eredmények alapján jól látható, hogy a C-AgNP esetében dózisfüggő toxikus hatást figyelhetünk meg: a részecskék koncentrációjának növelésével fokozatosan egyre kevesebb mikroba élte túl a kezelést. Ezzel szemben a GT-AgNP minta még a legkisebb alkalmazott koncentrációban is 100\%-os toxicitást okozott a vizsgált $E$. coli illetve $C r$. neoformans kultúrákban. 

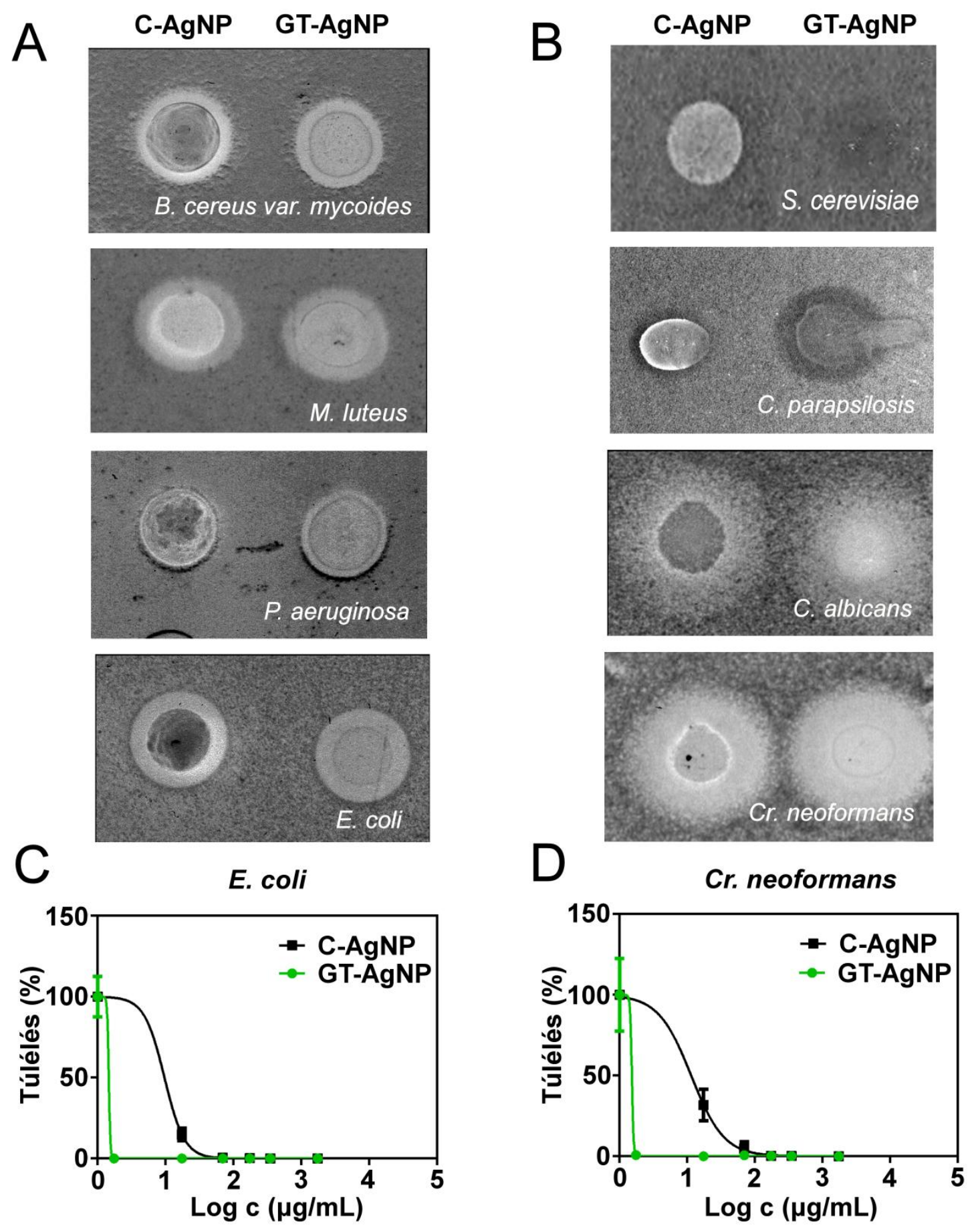

C

E. coli

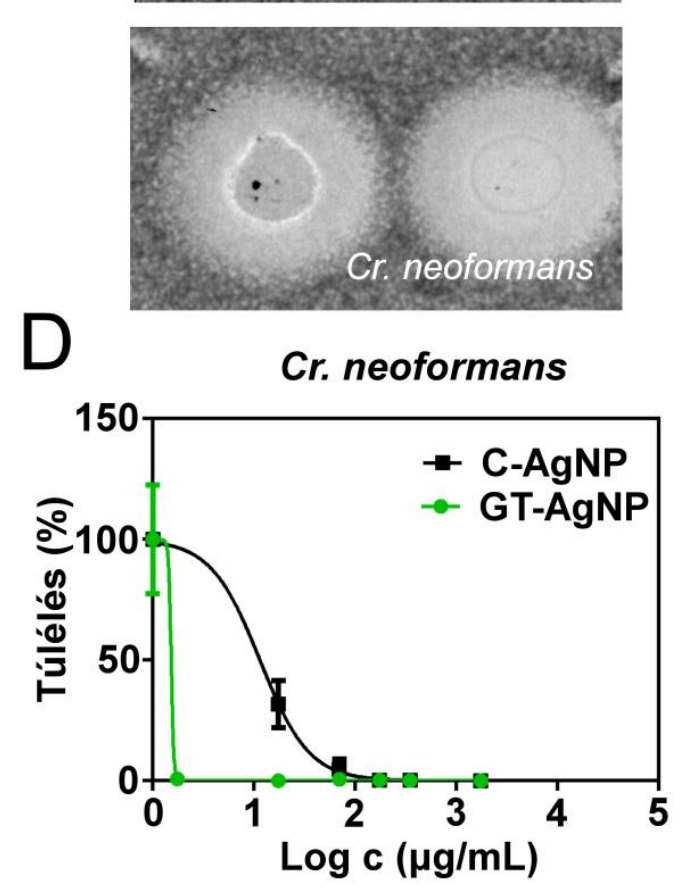

5.22. ábra. A növányi kivonatokkal előállított ezüst nanorészecskék antimikrobiális aktivitása. Agar diffúziós módszer (A-B): A lemezeket B. cereus var. mycoides, M. luteus, $P$. aeruginosa és $E$. coli $(\mathbf{A})$ valamint $S$. cerevisiae, $C$. parapsilosis, $C$. albicans és Cr neoformans (B) törzsekkel oltottuk le. C-AgNP és GT-AgNP kezelés hatása az E. coli $(\mathbf{C})$ és $C r$. neoformans túlélési arányára $(\mathbf{D})$. 
5.5. táblázat. Gátlási zónák az ezüst nanorészecskék jelenlétében

\begin{tabular}{lcc}
\hline Mikroorganizmus & $\begin{array}{c}\text { C-AgNP } \\
\text { gátlási zóna } \\
(\mathbf{m m}) *\end{array}$ & $\begin{array}{c}\text { GT-AgNP } \\
\text { gátlási zóna } \\
(\mathbf{m m}) *\end{array}$ \\
\hline B. cereus var. mycoides & $1,38 \pm 0,24$ & $1,63 \pm 0,13$ \\
M. luteus & $3,00 \pm 0,00$ & $4,00 \pm 0,00$ \\
E. coli & $1,75 \pm 0,14$ & $2,25 \pm 0,14$ \\
P. aeruginosa & $<1,00$ & $1,00 \pm 0,00$ \\
C. albicans & $4,00 \pm 0,00$ & $4,00 \pm 0,57$ \\
Cr. neoformans & $4,50 \pm 0,20$ & $4,75 \pm 0,14$ \\
C. parapsilosis & $<1,00$ & $1,66 \pm 0,57$ \\
S. cerevisiae & 0,00 & 0,00 \\
\hline *Az ezüst nanorészecskéket $17,5 \mathrm{mg} / \mathrm{mL}$ koncentrációban alkalmaztuk.
\end{tabular}

\subsubsection{Ezüst ionok koncentrációja}

A C-AgNP és a GT-AgNP minták eltérő biológiai aktivitásának lehetséges magyarázatát próbáltuk feltérképezni az ezüst nanorészecskékről felszabaduló ionok mennyiségének meghatározásával. ICP-MS vizsgálattal meghatároztuk, hogy 1 nap sejtkultúra médiumban való inkubálás alatt mennyi ezüst ion szabadult fel a nanorészecskékről. Ehhez mindkét ezüst minta esetében az előállított nanorészecskékből DMEM médiumban $17,5 \mathrm{mg} / \mathrm{mL}$ koncentrációjú oldatot készítettünk. A mintákat $37{ }^{\circ} \mathrm{C}$-on 24 órán keresztül inkubáltuk, majd a felülúszókat centrifugálással kinyertük és előkészítettük az ICP-MS méréshez.

A mérési adatok szerint az oldott ezüst koncentrációja a C-AgNP esetén

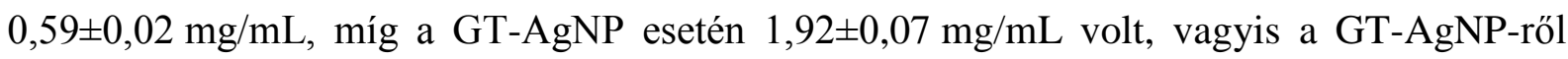
nagyjából három és félszer annyi ezüst ion tudott felszabadulni, mint a C-AgNP-ről. Ezek az eredményeink arra engednek következtetni, hogy habár a kávéval előállított nanorészecskék mérete négyszer kisebb volt, mint a zöld teával szintetizált nanorészecskéké, a C-AgNP minta esetében kevesebb ion tudott felszabadulni a részecskék felületéről. Valószínüsíthetően a TEM méréseknél megfigyelt, a részecskéket körülvevő stabilizáló mátrix akadályozta az ezüstionok kioldódását, ezáltal a részecskék toxicitása is csökkent.

Eredményeink alapján elmondható, hogy habár a növényi kivonatok alkalmazása az ezüst nanorészecskék szintézise során költséghatékony és környezetbarát, a kapott részecskék kémiai és biológiai tulajdonságait - csakúgy, mint a vas nanorészecskék esetében - jelentősen befolyásolja az alkalmazott redukálószer. 
Általánosan ismert tény, hogy a kisebb méretű nanorészecskék nagyobb fajlagos felületéröl több reaktív ezüst ion képes felszabadulni, így elméletben a kisebb részecskék nagyobb toxicitással rendelkeznek, a nagyobb méretü partikulumokhoz képest ${ }^{167}$.

Ugyanakkor, érdekes módon minden vizsgálatunk során azt tapasztaltuk, hogy a nagyobb részecskemérettel rendelkező GT-AgNP minta bizonyult toxikusabbnak. További vizsgálataink (ICP-MS) eredményei alapján feltételeztük, hogy ez a jelenség annak köszönhető, hogy a C-AgNP részecskéket körülvevő stabilizáló mátrix miatt 3,5-ször kevesebb ezüstion tudott felszabadulni a C-AgNP részecskék felszínéről. Azonban, mivel a CAgNP részecskék is hatékonynak bizonyultak az összes tesztelt mikroba ellen, viszont az emlős sejtekre nézve biokompatibilisabbak, így további ígéretes felhasználásukat elösegítő vizsgálatok elvégzése mellett számos érv szól.

Összegezve elmondható, hogy a különböző növényi kivonatok redukáló- és stabilizálószerként való alkalmazásával a részecskék biológiai aktivitása befolyásolható. $\mathrm{Az}$ eredményeink alapján a nanorészecskék szintézise során használt zöld kivonatok körültekintő kiválasztása és felhasználás előtt az előállított részecskék átfogó vizsgálata javasolt. 


\section{6. ÖSSZEFOGLALÁS}

Munkánk során különböző eljárások révén állítottunk elő, majd részletesen jellemztünk nulla vegyértékü vas nanorészecskéket. A teljesen zöld szintézismódszerek esetén növényi (kávé, zöld tea és vadszőlö) kivonatokat használtunk redukáló- és stabilizálószerként, míg a félig-zöld eljárásokban a vas nanorészecskék ugyan ipari vegyszerek (vas(II)- és vas(III)-klorid, vas(II)-szulfát, valamint nátrium-borihidrid vagy nátrium-ditionit) felhasználásával készültek, de minden reakciónál törekedtünk a szintézis paramétereit a költséghatékonyság, fenntarthatóság és környezetbarát zöld kémiai hármas egység jegyében tartani. Sikeresen állítottunk elő szobahőmérsékleten, környezeti körülmények mellett különböző kiindulási vas-sók és redukálószerek alkalmazásával vas nanorészecskéket erőforrás-igényes deoxigenált oldószerek helyett csapvíz használatával.

Meghatároztuk az előállított vas nanorészecskék átlagos szemcseméretét, kristályszerkezetét és redukciós kapacitását. Habár a félig-zöld úton előállított vas nanorészecskék kisebb átlagos átmérővel és nagyobb redukciós potenciállal rendelkeztek, mint a teljesen zöld szintézissel készült minták, az utóbbiak is elfogadható teljesítményt nyújtottak kísérleteink során.

Elsőként szintetizáltunk vas nanorészecskéket vadszőlőlevél (Parthenocissus quinquefolia, Virginia creeper) kivonat felhasználásával. Az előállított nanorészecskék jellemzőit röntgendiffrakciós, transzmissziós elektronmikroszkópiás és redoxpotenciál mérések segítségével határoztuk meg.

A kísérleti munka során valós környezeti mintában, illékony klórozott szénhidrogénnel szennyezett talajvízben teszteltük a félig-zöld szintézismódszerrel előállított vas nanorészecskék degradációs hatékonyságát. A vizsgálat során igazoltuk, hogy a vas nanorészecskék feleslegben adagolása minden esetben növelte a lebontás hatékonyságát. Emellett kimutattuk azt is, hogy a nanorészecskék előállítási módja ugyancsak jelentősen befolyásolta a vas részecskék redoxpotenciál értékeit és illékony klórozott szénhidrogén bontási teljesítményét: ugyanolyan körülmények között mindhárom vizsgált koncentrációban a nátrium-borohidriddel redukált vas nanorészecskék bizonyultak hatékonyabbnak.

Fontos megfigyelésünk továbbá, hogy a vas(II)-szulfátból nátrium-ditionittal redukált vas nanorészecskék $\left(\mathrm{nZVI}_{\mathrm{S}}{ }^{\mathrm{D}}\right.$ minta) mutatták a legnagyobb hasonlóságot a nátrium-borohidriddel redukált vas nanorészecskék teljesítményéhez.

A megvalósult terepi teszt alapján a félig-zöld szintézis során elöállított $\mathrm{nZVI}_{\mathrm{S}}{ }^{\mathrm{D}}$ minta alkalmasnak bizonyult illékony klórozott szénhidrogének lebontására. 
Eredményeinkkel igazoltuk, hogy a környezeti remediációban egy fenntartható, hatékony, gazdaságos alternatív megoldás lehet a vas(II)-szulfátból nátrium-ditionittal redukált vas nanorészecskék alkalmazása.

Azt is bizonyítottuk, hogy a vas szintézis során felhasznált kiindulási vas-sók és redukálószerek nemcsak a kialakult nanorészecske reaktivitását és morfológiáját (nátrium-borohidrid esetén nagyobb aktivitással rendelkező részecskéket kaptunk, míg nátrium-ditionit esetén kisebb aktivitással rendelkező nanoszálak is képződtek) határozzák meg, hanem befolyásolják a vas részecskék anaerob baktériumokra gyakorolt hatását, azaz a biológiai aktivitását is. Ennek következtében a környezeti kármentesítés során a remediáció hatékonyságának fokozása érdekében a megfelelő vas nanorészecske körültekintő kiválasztása javasolt.

Megállapítottuk, hogy $0,1 \mathrm{~g} / \mathrm{L}-\mathrm{es}$ koncentrációban mindegyik nanovas adagolása hatással volt a mikrokozmosz rendszerek mikrobiális összetételére és a deklorináló folyamatokra. Vizsgálatainkból kiderült, hogy a felhasznált redukálószerek és vas-sók mindegyik kombinációjából előállított nanovas részecskék 0,1 g/L-es koncentrációban alkalmazva csökkentették a Dehalococcoides populáció méretét. A $16 \mathrm{~S}$ rDNS és a dehalogenáz géneket tartalmazó baktériumok relatív mennyisége is lecsökkent mindegyik nanovas adagolása esetén, ugyanakkor a mikrokozmosz rendszerek összes mikrobaszáma nött.

A mikrokozmosz rendszerek gázkromatográfiás vizsgálata is megerősítette, hogy a biológiai deklorináló aktivitás lecsökkent a nanovas minták jelenlétében. A nátrium-ditionittal redukált nanovas minták mellett a szulfátredukáló baktériumok mennyisége megnőtt, a metanogén baktériumok mennyisége pedig lecsökkent. A deklorináló vizsgálatok azt mutatták, hogy metanogenezis csak a nátrium-borohidriddel redukált vas minták esetén történt.

A kapott eredményeink alapján elmondható, hogy ebben a koncentrációban mindegyik nanovas kezdetben gátolta a rendszerekben jelenlévő mikroflóra aktivitását, de a 20. napon a biotikus kontroll mintához közelítő értékeket kaptuk a populációk relatív arányában mindegyik minta esetén. Tehát kimutattuk — a szakirodalmi adatokkal egybehangzóan -, hogy a kezdeti gátló hatás után, az életben maradt populációk képesek voltak visszarendeződni a kiindulási mikroflóra összetételéhez hasonlóan, amely bizonyítottan reduktív dehalogenációs aktivitással rendelkezett. Mindez kiválóan megalapozza az előállított vas nanorészecskék alkalmazhatóságát későbbi terepi tesztek során, lehetővé téve egy kombinált kémiai-biológiai kezelés kidolgozását. 
A vas nanorészecskéknél tett érdekes megfigyeléseinket sikerült egy a szakirodalomban jól ismert, meghatározott jellemzőkkel rendelkező referencia anyagra, az ezüst nanorészecskékre kiterjeszteni. Tapasztalataink alapján, legfontosabb megállapításunk, hogy mind a vas, mind pedig az ezüst nanorészecske esetében a felhasznált redukálószer nemcsak a nanorészecskék méretét, alakját, hanem biológiai rendszerekben való viselkedését is meghatározza. Ezáltal a részecskék biológiai aktivitása befolyásolható, szabályozható.

Kávé és zöld tea kivonattal is sikeresen állítottunk elő nanoezüst részecskéket, amelyeknek elvégeztük komplex kémiai és biológiai vizsgálatát. A kapott eredményeink alapján mindkét ezüst nanorészecske hatékonynak bizonyult a tesztelt mikrobák ellen, habár a zöld teával előállított ezüst nanorészecskék (GT-AgNP) minden esetben jelentősen nagyobb toxikus hatást fejtettek ki a vizsgált baktérium és gomba törzsekre, mint a kávéval előállított ezüst nanorészecskék (C-AgNP). Azonban azt is meg kell jegyeznünk, hogy a GT-AgNP részecske az emlős sejteket is nagymértékben elpusztította, mely széles körü biológiai felhasználhatóságát jelentősen korlátozza. Másrészt, amellett, hogy a C-AgNP kiemelkedő antimikrobiális hatással rendelkezett az $E$. coli és $C r$. neoformans törzsek ellen, ezek a részecskék biokompatibilisnek bizonyultak az emlős sejtekre nézve.

A szakirodalomban elfogadott ténnyel szemben, meglepő módon minden vizsgálatunk során azt tapasztaltuk, hogy a nagyobb részecskemérettel rendelkező GT-AgNP minta bizonyult toxikusabbnak a C-AgNP-hez képest. ICP-MS méréseink alapján valószínüsítettük, hogy ez a jelenség annak köszönhető, hogy a C-AgNP részecskéket körülvevő stabilizáló mátrix miatt 3,5-ször kevesebb ezüstion tudott felszabadulni a C-AgNP részecskék felszínéről, és emiatt kisebb a C-AgNP nanorészecskék toxicitása. Mivel ezen nanorészecskék hatékonyan pusztították az összes tesztelt mikrobát, viszont az emlös sejtekre nézve biokompatibilisabbak, így további felhasználásuk mellett számottevő érvek sorakoznak.

Eredményeinket összegezve elmondható, hogy környezetbarát és költséghatékony eljárásokkal akár ipari méretben is előállhatóak változatos tulajdonságú, specifikus célokra felhasználható nanorészecskék. A szintézis során alkalmazott redukáló-, és stabilizálószerek különösen a növényi kivonatok - jelentősen befolyásolhatják a nanorészecskék kémiai jellemzőit és biológiai aktivitását, ezért a felhasznált redukálószer körültekintő kiválasztása és az előállított nanorészecskék fizikai, kémiai és biológiai jellemzőinek teljes körü azonosítása a felhasználás előtt mindenképpen javasolt. 


\section{SUMMARY}

In this dissertation the detailed characterisation of zero-valent iron nanoparticles produced by different synthesis methods have been discussed. The role of initial metal salts and reducing agents in the formation and characteristics of nanoparticles have also been studied. Plant (coffee, green tea and Virginia creeper) extracts were used as reducing and capping agents in case of green synthesis methods, while industrial chemicals (iron(II) and iron(III) sulphate, iron(III) chloride, sodium borohydride and sodium dithionite) were applied to prepare iron nanoparticles in case of semi-green procedures albeit trying to keep the synthesis parameters within the green chemical triangle of cost effectiveness, sustainability and environmental friendliness in all reactions. We successfully managed to produce iron nanoparticles at room temperature and ambient conditions applying different initial iron salts and reducing agents by using tap water instead of resource intensive deoxygenated solvents.

The average particle size, crystal structure and reduction capacity of the produced iron nanoparticles were determined. Although the iron nanoparticles prepared in the semi-green way had smaller average diameter and larger reduction potential than the samples made with green synthesis, the latter ones also showed good performance in our experiments.

It is also worth mentioning that we were the first to produce iron nanoparticles using Virginia creeper (Parthenocissus quinquefolia) extract. The produced nanoparticles were characterized by X-ray diffraction, transmission electron microscopy and oxidation/reduction potential measurements.

The reduction capacity of the iron nanoparticles prepared with the semi-green synthesis method was tested in a real environmental sample, in soil water contaminated by volatile chlorinated hydrocarbon. We have verified that with excessive dosing of the iron nanoparticles the efficiency of volatile chlorinated hydrocarbon decomposition increased in all the examined cases. It was also observed that the method of preparation of the iron nanoparticles largely influenced the performance of the samples: the nanoparticles reduced by sodium borohydride proved to be more efficient in reduction of volatile chlorinated hydrocarbons in all the three concentrations tested under the same conditions.

It was confirmed that the iron nanoparticles reduced by sodium borohydride outperformed the iron nanoparticles synthesized by using sodium dithionite both in the measured oxidation/reduction potential values, and in the volatile chlorinated hydrocarbon reduction tests. Another important observation was that the iron nanoparticles reduced from 
ferrous(II) sulphate by sodium dithionite $\left(\mathrm{nZVI}_{\mathrm{S}}{ }^{\mathrm{D}}\right)$ showed the highest similarity to the performance of the iron nanoparticles reduced by sodium borohydride.

It was demonstrated that the $\mathrm{nZVI}_{S}{ }^{\mathrm{D}}$ sample produced by the semi-green synthesis proved to be capable of reducing volatile chlorinated hydrocarbons based on the performed field test.

Our results confirmed that the application of iron nanoparticles reduced from ferrous(II) sulphate by sodium dithionite may be a sustainable, efficient and economical alternative in environmental remediation.

We proved that the initial iron salts and reducing agents used in iron synthesis do not only define the reactivity and morphology of the produced nanoparticles, but also influence the biological activity of the iron particles (their impact on anaerobic bacteria). Therefore in environmental remediation it is advisable to exercise great care in selecting the suitable iron nanoparticles in order to enhance remediation.

It was ascertained that the introduction of any nanoiron sample in the $0.1 \mathrm{~g} / \mathrm{L}$ concentration had an impact on the microbial composition of the microcosm systems and on the dechlorinating processes. Our tests revealed that the iron nanoparticles, prepared from any combination of the used reducing agents and iron salts, applied in a $0.1 \mathrm{~g} / \mathrm{L}$ concentration reduced the size of the Dehalococcoides population. The relative amount of $16 \mathrm{~S}$ rDNS and dehalogenase genes containing bacteria also decreased with the addition of any nanoscale iron while the total amount of microbes increased.

The above results were also supported by the gas chromatography test of the microcosm systems, the biological dechlorination activity dropped in the presence of nanoiron samples. The amount of sulphate reducing bacteria increased and the amount of methanogenic bacteria decreased in the presence of the nanoiron samples reduced by sodium dithionite. The methanogenesis was observed only in case of the iron samples reduced with sodium borohydride as revealed by the dechlorinating tests.

Our findings showed that initially each nanoiron sample in this concentration inhibited the activity of the microflora present in the microcosm systems, however, the relative amount of the populations showed similar values close to the biotic control sample on the twentieth day in case of each of the samples. Thus it could be demonstrated - in line with the literature data - that following an initial inhibitory effect, surviving populations managed to achieve a similar composition like that of the initial microflora, which had a proven reductive dehalogenation activity. All these findings give an excellent basis for the applicability of the 
produced iron nanoparticles for later field tests, enabling the elaboration of a combined biological and chemical treatment.

Finally we tried to extend the interesting observations we made with iron nanoparticles to silver nanoparticles, a reference material with defined features, which are well described in the literature. Our most important experience-based finding was that the reducing agent applied for nanoiron or nanosilver production can largely define not only the size and shape of the nanoparticles but also their behaviour in biological systems.

Silver nanoparticles were also successfully synthesized using coffee and green tea extracts, and their chemical and biological characteristics were investigated. It was proven in our experiments that it is recommended to have a circumspect selection of the green extracts used for the synthesis of nanoparticles, and a comprehensive screen of the products should be carried out prior their applications to delineate their behaviour in the presence of living systems. It was found that both AgNPs proved to be effective in the examined concentrations against nearly all the tested microbes; however, GT-AgNPs performed always markedly better in toxicity and antimicrobial screens than C-AgNP counterparts. It is also noteworthy that apart from their antimicrobial activity, GT-AgNPs were also highly toxic against mammalian cells, which limits their potential applications. On the contrary, C-AgNPs exhibited an extensive inhibitory action on Cr. neoformans as well as on E. coli; however, these particles were biocompatible with the tested HeLa and NIH/3T3 cells, showing no mammalian cytotoxicity.

Surprisingly, in every biological test we performed, in contrast to the literature data, we found that bigger sized GT-AgNPs resulted to be more effective than smaller C-AgNPs. In fact, ICP-MS measurements verified that $\sim 3.5$ times more silver ions can be released from GT-AgNPs than from C-AgNPs, which might be the direct consequence of the thick matrix, where C-AgNPs seem to be completely embedded. However, despite the lower Ag-ionreleasing capability of C-AgNPs, they were also effective against microbes without being cytotoxic, which renders C-AgNPs as attractive potential candidates for further applications.

The eco-friendly, cost-effective green synthesis of nanoparticles can be realized even on the industrial scale. However, as the chemical nature and the composition of the reducing and capping agents applied during synthesis - especially when biological extracts are utilized - can significantly modify the activity of the obtained nanoparticles in living systems, a thorough characterization of their physical, chemical and biological properties must obligatorily precede their large scale applications. 


\section{KÖSZÖNETNYILVÁNÍTÁS}

Mindenekelőtt szeretném kifejezni köszönetemet témavezetőimnek, Dr. Kónya Zoltán tanszékvezető egyetemi tanárnak és Dr. Kiricsi Mónika egyetemi adjunktusnak, akik biztosították a doktori disszertációm megírásához szükséges feltételeket. Köszönöm, hogy tanácsaikkal, biztató szavaikkal végigvezettek a doktori fokozat megszerzéséig vezető rögös úton. Köszönöm Dr. Kukovecz Ákos egyetemi docensnek, hogy segítséget nyújtott eredményeim értelmezésében és publikálásában.

Szeretném megköszönni a Bay Zoltán Alkalmazott Kutatási Közhasznú Nonprofit Kft. Biotechnológiai Divízió igazgatójának, Dr. Kiss Istvánnak és az intézet munkatársainak segítségét a biológiai vizsgálatok során. Külön köszönettel tartozom Balázs Margitnak, aki a kezdetektől fogva töretlenül hitt bennem és a közös munkánkban. Köszönöm az önzetlen támogatását, türelmét, segítsége nélkül ez a dolgozat nem jöhetett volna létre.

Hálásan köszönöm Dr. Pfeiffer Ilonának a rengeteg segítséget és támogatást, amelyet munkám során nyújtott. Közös munkánk során sokat tanultam, mind a kísérlettervezésröl, mind pedig az eredmények alapos kiértékeléséről. Köszönöm, hogy szakértelmével hozzájárult dolgozatom színvonalának emeléséhez. A humán sejtes kísérletek elvégzését és kiértékelését külön köszönöm Kovács Dávidnak és Igaz Nórának. Köszönöm a jó hangulatú megbeszéléseinket is.

Köszönetet szeretnék mondani Dr. Tolmacsov Péternek a gázkromatográfiás mérések és Dr. Galbács Gábornak az ICP-MS vizsgálatok elvégzésért.

Értékes elméleti és gyakorlati segítségnyújtásukért köszönet illeti Dr. Rutkai Editet, Dr. Szvetnik Attilát és Németh Alexandrát. Köszönöm Dr. Guzsvány Valériának, hogy példamutatásával és munkaszeretetével hozzájárult személyes és szakmai fejlődésemhez.

Köszönöm a tanszék összes dolgozójának, elsősorban Timinek, Dórinak, Lacinak, Balázsnak, Daninak, Iminek a kellemes munkahelyi légkört és a szakmai segítséget. Külön köszönöm Gábor és Peti támogató személyes és szakmai tanácsait. Köszönöm Marcynak, Zitának, Zolinak és Petinek a nanolaboros éveket.

Szeretném megköszönni barátaimnak a támogatásukat. Köszönöm keresztszüleimnek és az egész családomnak a biztatást, különösen Kati néninek vagyok hálás az indíttatásért.

Végül a legfontosabb, hálával tartozom Szüleimnek és páromnak Csabinak, akik mindvégig mellettem álltak a nehézségek és kételyeim során, kitartóan támogattak és bátorítottak céljaim elérésében, és mindig mindenben számíthattam rájuk.

Hála érte Istennek! 


\section{IRODALOMJEGYZÉK}

1. Puzder, T., Csáki, F., Gruiz, K., Horváth, Z., Márton, T. Sajgó, Z. , Kármentesítési kézikönyv 4. Környezetvédelemi Minisztérium: Budapest, 2001.

2. Kádár, I., Kármentesítési kézikönyv 2. A szennyezett talajok vizsgálatáról. Környezetvédelmi Minisztérium: 1998.

3. Országos Környezeti Kármentesítési Program - http://www.kvvm.hu/.

4. Barótfi, I., Környezettechnika. Mezőgazda Kiadó: Budapest, 2000.

5. Tsai, W.-T., Toxic volatile organic compounds (VOCs) in the atmospheric environment: regulatory aspects and monitoring in Japan and Korea. Environments 2016, 3, (3), 23.

6. Russell, C. S., Safe drinking water: current and future problems. Routledge: 2016.

7. Singh, R. L., Principles and applications of environmental biotechnology for a sustainable future. Springer: 2016.

8. Mueller, N. C.; Nowack, B., Nanoparticles for remediation: solving big problems with little particles. Elements 2010, 6, (6), 395-400.

9. Zhang, W., Nanoscale iron particles for environmental remediation: An overview. Journal of Nanoparticle Research 2003, 5, (3/4), 323-332.

10. Wcisło, E.; Bronder, J.; Bubak, A.; Rodríguez-Valdés, E.; Gallego, J. L. R., Human health risk assessment in restoring safe and productive use of abandoned contaminated sites. Environment International 2016, 94, 436-448.

11. Környezetvédelmi információ Honlap - Szennyezett területek Magyarországon, http://enfo.agt.bme.hu/drupal/node/6812.

12. Gerarde, H. W., Toxicological studies on hydrocarbons. Archives of Environmental Health: An International Journal 1963, 6, (3), 329-341.

13. Samanta, S. K.; Singh, O. V.; Jain, R. K., Polycyclic aromatic hydrocarbons: environmental pollution and bioremediation. Trends in Biotechnology 2002, 20, (6), 243-248.

14. Traiger, G. J.; Plaa, G. L., Chlorinated hydrocarbon toxicity. Archives of Environmental Health: An International Journal 1974, 28, (5), 276-278.

15. Goldberg, E. D., Halogenated hydrocarbons: past, present and near-future problems. Science of The Total Environment 1991, 100, 17-28.

16. Muftikian, R., A method for the rapid dechlorination of low molecular weight chlorinated hydrocarbons in water. Water Research 1995, 29, (10), 2434-2439.

17. Preisich, M., Vegyipari termékek. Müszaki Könyvkiadó: Budapest, 1974.

18. Dokou, Z.; Pinder, G. F., Optimal search strategy for the definition of a DNAPL source. Journal of Hydrology 2009, 376, (3-4), 542-556.

19. Szabó, I. Szénhidrogénekkel szennyezett területek mikroba populációjának jellemzése Phd Dolgozat. 2011.

20. Hellman, B.; Brandt, I., Effects of carcinogenic halogenated aliphatic hydrocarbons on $[3 \mathrm{H}]$ thymidine incorporation into various organs of the mouse A comparison between 1,2-dibromoethane. Mutation Research/Fundamental and Molecular Mechanisms of Mutagenesis 1986, 163, (2), 193-199.

21. Deng, B.; Burris, D. R.; Campbell, T. J., Reduction of vinyl chloride in metallic iron-water systems. Environmental Science \& Technology 1999, 33, (15), 2651-2656. 
22. Dijkmans, R., Methodology for selection of best available techniques (BAT) at the sector level. Journal of Cleaner Production 2000, 8, (1), 11-21.

23. Gruiz, K., A területhasználat, a környezeti kockázat és a természetes szennye-ző anyagcsökkenés összefüggései. Környezetvédelmi füzetek. BME OMIKK: Budapest, 2003; p 58-60.

24. Kreuk, J. F., Advantages of in-situ remediation of polluted soil and practical problems encountered during its performance. Springer Netherlands: 2005; Vol. 52, p 257-265.

25. Pliška, V.; Testa, B.; van de Waterbeemd, H., Lipophilicity in drug action and toxicology. VCH Verlagsgesellschaft GmbH: 1996.

26. de Jong, R. M.; Dijkstra, B. W., Structure and mechanism of bacterial dehalogenases: different ways to cleave a carbon-halogen bond. Current Opinion in Structural Biology 2003, 13, (6), 722-730.

27. Abbott, W., Microcosm studies on estuarine waters I. The replicability of microcosms. Journal (Water Pollution Control Federation) 1966, 258-270.

28. Kao, C.; Prosser, J., Intrinsic bioremediation of trichloroethylene and chlorobenzene: field and laboratory studies. Journal of hazardous materials 1999, 69, (1), 67-79.

29. Gruiz, K., Soil testing triad and interactive ecotoxicity tests for contaminated soil. Soil remediation series 2005, 6 .

30. Smidt, H.; de Vos, W. M., Anaerobic microbial dehalogenation. Annual Review of Microbiology 2004, 58, (1), 43-73.

31. Ahn, Y.-B.; Rhee, S.-K.; Fennell, D. E.; Kerkhof, L. J.; Hentschel, U.; Häggblom, M. M., Reductive dehalogenation of brominated phenolic compounds by microorganisms associated with the marine sponge Aplysina aerophoba. Applied and environmental microbiology 2003, 69, (7), 4159-4166.

32. Bradley, P. M.; Chapelle, F. H.; Lovley, D. R., Humic acids as electron acceptors for anaerobic microbial oxidation of vinyl chloride and dichloroethene. Applied and Environmental Microbiology 1998, 64, (8), 3102-3105.

33. Stroo, H. F.; Ward, C. H., In situ remediation of chlorinated solvent plumes. 2010.

34. Middeldorp, P. J. M.; Luijten, M. L. G. C.; Pas, B. A. v. d.; Eekert, M. H. A. v.; Kengen, S. W. M.; Schraa, G.; Stams, A. J. M., Anaerobic microbial reductive dehalogenation of chlorinated ethenes. Bioremediation Journal 1999, 3, (3), 151-169.

35. Fathepure, B. Z.; Boyd, S. A., Dependence of tetrachloroethylene dechlorination on methanogenic substrate consumption by Methanosarcina sp. strain DCM. Applied and Environmental Microbiology 1988, 54, (12), 2976-2980.

36. Terzenbach, D. P.; Blaut, M., Transformation of tetrachloroethylene to trichloroethylene by homoacetogenic bacteria. FEMS microbiology letters 1994, 123, (1-2), 213-218.

37. Cole, J. R.; Fathepure, B. Z.; Tiedje, J. M., Tetrachloroethene and 3-chlorobenzoate dechlorination activities are co-induced inDesulfomonile tiedjei DCB-1. Biodegradation 1995, 6, (2), 167-172.

38. Leisinger, T., Biodegradation of chlorinated aliphatic compounds. Current opinion in biotechnology 1996, 7, (3), 295-300.

39. DeWeerd, K. A.; Mandelco, L.; Tanner, R. S.; Woese, C. R.; Suflita, J. M., Desulfomonile tiedjei gen. nov. and sp. nov., a novel anaerobic, dehalogenating, sulfatereducing bacterium. Archives of Microbiology 1990, 154, (1), 23-30.

40. Bradley, P. M., History and ecology of chloroethene biodegradation: a review. Bioremediation Journal 2003, 7, (2), 81-109. 
41. He, J.; Ritalahti, K. M.; Aiello, M. R.; Löffler, F. E., Complete detoxification of vinyl chloride by an anaerobic enrichment culture and identification of the reductively dechlorinating population as a Dehalococcoides species. Applied and Environmental Microbiology 2003, 69, (2), 996-1003.

42. Sanford, R. A.; Cole, J. R.; Löffler, F.; Tiedje, J. M., Characterization of Desulfitobacterium chlororespirans sp. nov., which grows by coupling the oxidation of lactate to the reductive dechlorination of 3-chloro-4-hydroxybenzoate. Applied and environmental microbiology 1996, 62, (10), 3800-3808.

43. Holliger, C.; Wohlfarth, G.; Diekert, G., Reductive dechlorination in the energy metabolism of anaerobic bacteria. FEMS Microbiology Reviews 1998, 22, (5), 383-398.

44. Maymo-Gatell, X.; Chien, Y.-t.; Gossett, J. M.; Zinder, S. H., Isolation of a bacterium that reductively dechlorinates tetrachloroethene to ethene. Science 1997, 276, (5318), 1568-1571.

45. Maymo-Gatell, X.; Anguish, T.; Zinder, S. H., Reductive dechlorination of chlorinated ethenes and 1, 2-dichloroethane by "Dehalococcoides ethenogenes" 195. Applied and Environmental Microbiology 1999, 65, (7), 3108-3113.

46. Löffler, F. E.; Yan, J.; Ritalahti, K. M.; Adrian, L.; Edwards, E. A.; Konstantinidis, K. T.; Müller, J. A.; Fullerton, H.; Zinder, S. H.; Spormann, A. M., Dehalococcoides mccartyi gen. nov., sp. nov., obligately organohalide-respiring anaerobic bacteria relevant to halogen cycling and bioremediation, belong to a novel bacterial class, Dehalococcoidia classis nov., order Dehalococcoidales ord. nov. and family Dehalococcoidaceae fam. nov., within the phylum Chloroflexi. International journal of systematic and evolutionary microbiology 2013, 63, (2), 625-635.

47. Duhamel, M.; Mo, K.; Edwards, E. A., Characterization of a highly enriched Dehalococcoides-containing culture that grows on vinyl chloride and trichloroethene. Applied and Environmental Microbiology 2004, 70, (9), 5538-5545.

48. Yu, S.; Semprini, L., Enhanced reductive dechlorination of PCE DNAPL with TBOS as a slow-release electron donor. Journal of hazardous materials 2009, 167, (1), 97-104.

49. Futagami, T.; Goto, M.; Furukawa, K., Biochemical and genetic bases of dehalorespiration. The chemical record 2008, 8, (1), 1-12.

50. Amann, R. I.; Ludwig, W.; Schleifer, K.-H., Phylogenetic identification and in situ detection of individual microbial cells without cultivation. Microbiological reviews 1995, 59, (1), 143-169.

51. Yang, B.; Wang, Y.; Qian, P.-Y., Sensitivity and correlation of hypervariable regions in 16S rRNA genes in phylogenetic analysis. BMC bioinformatics 2016, 17, (1), 1.

52. Major, D. W.; McMaster, M. L.; Cox, E. E.; Edwards, E. A.; Dworatzek, S. M.; Hendrickson, E. R.; Starr, M. G.; Payne, J. A.; Buonamici, L. W., Field demonstration of successful bioaugmentation to achieve dechlorination of tetrachloroethene to ethene. Environmental Science \& Technology 2002, 36, (23), 5106-5116.

53. Scheutz, C.; Durant, N. d.; Dennis, P.; Hansen, M. H.; Jørgensen, T.; Jakobsen, R.; Cox, E. e.; Bjerg, P. L., Concurrent ethene generation and growth of Dehalococcoides containing vinyl chloride reductive dehalogenase genes during an enhanced reductive dechlorination field demonstration. Environmental science \& technology 2008, 42, (24), 9302-9309.

54. He, J.; Sung, Y.; Krajmalnik - Brown, R.; Ritalahti, K. M.; Löffler, F. E., Isolation and characterization of Dehalococcoides sp. strain FL2, a trichloroethene (TCE) - and 1, 
2 - dichloroethene - respiring anaerobe. Environmental Microbiology 2005, 7, (9), 1442-1450.

55. Taş, N.; Eekert, V.; Miriam, H.; De Vos, W. M.; Smidt, H., The little bacteria that candiversity, genomics and ecophysiology of 'Dehalococcoides' spp. in contaminated environments. Microbial biotechnology 2010, 3, (4), 389-402.

56. Sung, Y.; Ritalahti, K. M.; Apkarian, R. P.; Löffler, F. E., Quantitative PCR confirms purity of strain GT, a novel trichloroethene-to-ethene-respiring Dehalococcoides isolate. Applied and Environmental Microbiology 2006, 72, (3), 1980-1987.

57. Müller, J. A.; Rosner, B. M.; Von Abendroth, G.; Meshulam-Simon, G.; McCarty, P. L.; Spormann, A. M., Molecular identification of the catabolic vinyl chloride reductase from Dehalococcoides sp. strain VS and its environmental distribution. Applied and Environmental Microbiology 2004, 70, (8), 4880-4888.

58. Fennell, D. E.; Gossett, J. M., Microcosms for site-specific evaluation of enhanced biological reductive dehalogenation. Springer: 2004; p 385-420.

59. Yang, Y.; McCarty, P. L., Competition for hydrogen within a chlorinated solvent dehalogenating anaerobic mixed culture. Environmental Science \& Technology 1998, 32, (22), 3591-3597.

60. Lovley, D. R.; Chapelle, F. H.; Woodward, J. C., Use of dissolved H2 concentrations to determine distribution of microbially catalyzed redox reactions in anoxic groundwater. Environmental Science \& Technology 1994, 28, (7), 1205-1210.

61. Smatlak, C. R.; Gossett, J. M.; Zinder, S. H., Comparative kinetics of hydrogen utilization for reductive dechlorination of tetrachloroethene and methanogenesis in an anaerobic enrichment culture. Environmental Science \& Technology 1996, 30, (9), 2850-2858.

62. Chapelle, F. H.; Bradley, P. M., Microbial acetogenesis as a source of organic acids in ancient Atlantic Coastal Plain sediments. Geology 1996, 24, (10), 925-928.

63. Ballapragada, B. S.; Stensel, H. D.; Puhakka, J.; Ferguson, J. F., Effect of hydrogen on reductive dechlorination of chlorinated ethenes. Environmental science \& technology 1997, 31, (6), 1728-1734.

64. Henry, S. M.; Hardcastle, C. H.; Warner, S. D., Chlorinated solvent and DNAPL remediation: an overview of physical, chemical, and biological processes. Chlorinated Solvent and DNAPL Remediation 2003, 837, 1-20.

65. Townsend, G. T.; Suflita, J. M., Influence of sulfur oxyanions on reductive dehalogenation activities in Desulfomonile tiedjei. Applied and environmental microbiology 1997, 63, (9), 3594-3599.

66. Arnold, W. A.; Ball, W. P.; Roberts, A. L., Polychlorinated ethane reaction with zerovalent zinc: pathways and rate control. Journal of Contaminant Hydrology 1999, 40, (2), 183-200.

67. Lee, G.; Park, J., Reaction of zero-valent magnesium with water: Potential applications in environmental remediation. Geochimica et Cosmochimica Acta 2013, 102, 162-174.

68. Fu, F.; Dionysiou, D. D.; Liu, H., The use of zero-valent iron for groundwater remediation and wastewater treatment: a review. Journal of Hazardous Materials 2014, 267, 194-205.

69. Stefaniuk, M.; Oleszczuk, P.; Ok, Y. S., Review on nano zerovalent iron (nZVI): From synthesis to environmental applications. Chemical Engineering Journal 2016, 287, 618632. 
70. Li, X.-q.; Elliott, D. W.; Zhang, W.-x., Zero-valent iron nanoparticles for abatement of environmental pollutants: materials and engineering aspects. Critical reviews in solid state and materials sciences 2006, 31, (4), 111-122.

71. Gillham, R. W.; O'Hannesin, S. F., Enhanced degradation of halogenated aliphatics by zero - valent iron. Ground water 1994, 32, (6), 958-967.

72. Reynolds, G. W.; Hoff, J. T.; Gillham, R. W., Sampling bias caused by materials used to monitor halocarbons in groundwater. Environmental Science \& Technology 1990, 24, (1), 135-142.

73. Taghavy, A.; Costanza, J.; Pennell, K. D.; Abriola, L. M., Effectiveness of nanoscale zero-valent iron for treatment of a PCE-DNAPL source zone. Journal of Contaminant Hydrology 2010, 118, (3-4), 128-142.

74. Liu, Y.; Majetich, S. A.; Tilton, R. D.; Sholl, D. S.; Lowry, G. V., TCE dechlorination rates, pathways and efficiency of nanoscale iron particles with different properties. Environmental Science \& Technology 2005, 39, (5), 1338-1345.

75. Phenrat, T.; Schoenfelder, D.; Losi, M.; Yi, J.; Peck, S. A.; Lowry, G. V., Treatability study for a TCE contaminated area using nanoscale- and microscale-zerovalent iron particles: reactivity and reactive life time. 2010, 1027, 183-202.

76. Wang, C.-B.; Zhang, W.-X., Synthesizing nanoscale iron particles for rapid and complete dechlorination of TCE and PCBs. Environmental science \& technology 1997, $31,(7), 2154-2156$.

77. Zhu, H.; Jia, Y.; Wu, X.; Wang, H., Removal of arsenic from water by supported nano zero-valent iron on activated carbon. Journal of Hazardous Materials 2009, 172, (2-3), 1591-1596.

78. Kim, S. A.; Kamala-Kannan, S.; Lee, K.-J.; Park, Y.-J.; Shea, P. J.; Lee, W.-H.; Kim, H.-M.; Oh, B.-T., Removal of $\mathrm{Pb}(\mathrm{II})$ from aqueous solution by a zeolite-nanoscale zerovalent iron composite. Chemical Engineering Journal 2013, 217, 54-60.

79. Arnold, W. A.; Roberts, A. L., Pathways and kinetics of chlorinated ethylene and chlorinated acetylene reaction with $\mathrm{Fe}(0)$ particles. Environmental Science \& Technology 2000, 34, (9), 1794-1805.

80. Matheson, L. J.; Tratnyek, P. G., Reductive dehalogenation of chlorinated methanes by iron metal. Environmental Science \& Technology 1994, 28, (12), 2045-2053.

81. Snoeyink, V. L.; Jenkins, D., Water chemistry. Wiley: 1980.

82. Langmuir, D., Aqueous environmental geochemistry. 1997.

83. Geomechanics Kutató, F., Szolgáltató és Tanácsadó Betéti Társaság, Passzív kezelések: reaktív falak 2007.

84. Mueller, N. C.; Braun, J.; Bruns, J.; Černík, M.; Rissing, P.; Rickerby, D.; Nowack, B., Application of nanoscale zero valent iron (NZVI) for groundwater remediation in Europe. Environmental Science and Pollution Research 2011, 19, (2), 550-558.

85. Tosco, T.; Papini, M. P.; Viggi, C. C.; Sethi, R., Nanoscale zerovalent iron particles for groundwater remediation: a review. Journal of Cleaner Production 2014, 77, 10-21.

86. Tratnyek, P. G.; Scherer, M. M.; Johnson, T. L.; Matheson, L. J., Permeable reactive barriers of iron and other zero-valent metals. Environmental Science and Pollution Control Series 2003, 371-422.

87. Hozalski, R. M.; Zhang, L.; Arnold, W. A., Reduction of haloacetic acids by Fe0: Implications for treatment and fate. Environmental science \& technology 2001, 35, (11), 2258-2263. 
88. Wang, Y.; Zhou, D.; Wang, Y.; Wang, L.; Cang, L., Automatic pH control system enhances the dechlorination of 2,4,4'-trichlorobiphenyl and extracted PCBs from contaminated soil by nanoscale $\mathrm{Fe} 0$ and $\mathrm{Pd} / \mathrm{Fe} 0$. Environmental Science and Pollution Research 2011, 19, (2), 448-457.

89. Xie, Y.; Dong, H.; Zeng, G.; Tang, L.; Jiang, Z.; Zhang, C.; Deng, J.; Zhang, L.; Zhang, Y., The interactions between nanoscale zero-valent iron and microbes in the subsurface environment: A review. Journal of Hazardous Materials 2017, 321, 390-407.

90. Savolainen, K.; Alenius, H.; Norppa, H.; Pylkkänen, L.; Tuomi, T.; Kasper, G., Risk assessment of engineered nanomaterials and nanotechnologies-A review. Toxicology 2010, 269, (2-3), 92-104.

91. Foss Hansen, S.; Maynard, A.; Baun, A.; Tickner, J. A., Late lessons from early warnings for nanotechnology. Nature Nanotechnology 2008, 3, (8), 444-447.

92. Bruton, T. A.; Pycke, B. F. G.; Halden, R. U., Effect of nanoscale zero-valent iron treatment on biological reductive dechlorination: A review of current understanding and research needs. Critical Reviews in Environmental Science and Technology 2014, 45, (11), 1148-1175.

93. Xiu, Z.-m.; Jin, Z.-h.; Li, T.-1.; Mahendra, S.; Lowry, G. V.; Alvarez, P. J., Effects of nano-scale zero-valent iron particles on a mixed culture dechlorinating trichloroethylene. Bioresource Technology 2010, 101, (4), 1141-1146.

94. Diao, M.; Yao, M., Use of zero-valent iron nanoparticles in inactivating microbes. Water research 2009, 43, (20), 5243-5251.

95. Lee, C.; Kim, J. Y.; Lee, W. I.; Nelson, K. L.; Yoon, J.; Sedlak, D. L., Bactericidal effect of zero-valent iron nanoparticles on Escherichia coli. Environmental science \& technology 2008, 42, (13), 4927-4933.

96. Marsalek, B.; Jancula, D.; Marsalkova, E.; Mashlan, M.; Safarova, K.; Tucek, J.; Zboril, R., Multimodal action and selective toxicity of zerovalent iron nanoparticles against cyanobacteria. Environmental science \& technology 2012, 46, (4), 2316-2323.

97. Li, Z.; Greden, K.; Alvarez, P. J.; Gregory, K. B.; Lowry, G. V., Adsorbed polymer and NOM limits adhesion and toxicity of nano scale zerovalent iron to $E$. coli. Environmental science \& technology 2010, 44, (9), 3462-3467.

98. Fang, J.; Lyon, D. Y.; Wiesner, M. R.; Dong, J.; Alvarez, P. J., Effect of a fullerene water suspension on bacterial phospholipids and membrane phase behavior. Environmental science \& technology 2007, 41, (7), 2636-2642.

99. Gogoi, S. K.; Gopinath, P.; Paul, A.; Ramesh, A.; Ghosh, S. S.; Chattopadhyay, A., Green fluorescent protein-expressing Escherichia coli as a model system for investigating the antimicrobial activities of silver nanoparticles. Langmuir 2006, 22, (22), 9322-9328.

100. Xiu, Z.-m.; Gregory, K. B.; Lowry, G. V.; Alvarez, P. J., Effect of bare and coated nanoscale zerovalent iron on tce A and vcrA gene expression in Dehalococcoides spp. Environmental science \& technology 2010, 44, (19), 7647-7651.

101. Fajardo, C.; Ortíz, L.; Rodríguez-Membibre, M.; Nande, M.; Lobo, M.; Martin, M., Assessing the impact of zero-valent iron (ZVI) nanotechnology on soil microbial structure and functionality: a molecular approach. Chemosphere 2012, 86, (8), 802-808.

102. Kirschling, T. L.; Gregory, K. B.; Minkley, J., Edwin G; Lowry, G. V.; Tilton, R. D., Impact of nanoscale zero valent iron on geochemistry and microbial populations in trichloroethylene contaminated aquifer materials. Environmental science \& technology 2010, 44, (9), 3474-3480. 
103. Ponder, S. M.; Darab, J. G.; Mallouk, T. E., Remediation of Cr (VI) and Pb (II) aqueous solutions using supported, nanoscale zero-valent iron. Environmental Science \& Technology 2000, 34, (12), 2564-2569.

104. Holliger, C.; Schraa, G.; Stams, A.; Zehnder, A., A highly purified enrichment culture couples the reductive dechlorination of tetrachloroethene to growth. Applied and Environmental Microbiology 1993, 59, (9), 2991-2997.

105. F Chen, K.; Y Yeh, T.; M Kao, C.; P Sung, W.; C Lin, C., Application of nanoscale zero-valent iron (nZVI) to enhance microbial reductive dechlorination of TCE: a feasibility study. Current Nanoscience 2012, 8, (1), 55-59.

106. Yin, W.; Wu, J.; Li, P.; Lin, G.; Wang, X.; Zhu, B.; Yang, B., Reductive transformation of pentachloronitrobenzene by zero-valent iron and mixed anaerobic culture. Chemical engineering journal 2012, 210, 309-315.

107. Tilston, E. L.; Collins, C. D.; Mitchell, G. R.; Princivalle, J.; Shaw, L. J., Nanoscale zerovalent iron alters soil bacterial community structure and inhibits chloroaromatic biodegradation potential in Aroclor 1242-contaminated soil. Environmental pollution 2013, 173, 38-46.

108. Köber, R.; Hollert, H.; Hornbruch, G.; Jekel, M.; Kamptner, A.; Klaas, N.; Maes, H.; Mangold, K. M.; Martac, E.; Matheis, A.; Paar, H.; Schäffer, A.; Schell, H.; Schiwy, A.; Schmidt, K. R.; Strutz, T. J.; Thümmler, S.; Tiehm, A.; Braun, J., Nanoscale zero-valent iron flakes for groundwater treatment. Environmental Earth Sciences 2014, 72, (9), 3339-3352.

109. Shu, Z.; Wang, J.; Huang, Y., Study of inactivating sulfate reducing bacteria with zerovalent iron nanoparticles. Huan jing ke xue= Huanjing kexue/[bian ji, Zhongguo ke xue yuan huan jing ke xue wei yuan hui" Huan jing ke xue" bian ji wei yuan hui.] 2011, 32, (10), 3040-3044.

110. Gao, W.; Wang, J., The environmental impact of micro/nanomachines: a review. Acs Nano 2014, 8, (4), 3170-3180.

111. Li, S.; Yan, W.; Zhang, W.-X., Solvent-free production of nanoscale zero-valent iron (nZVI) with precision milling. Green Chemistry 2009, 11, (10), 1618-1626.

112. Iqbal, P.; Preece, J. A.; Mendes, P. M., Nanotechnology: The "top-down" and "bottomup" approaches. 2012.

113. Wender, H.; Migowski, P.; Feil, A. F.; Teixeira, S. R.; Dupont, J., Sputtering deposition of nanoparticles onto liquid substrates: Recent advances and future trends. Coordination Chemistry Reviews 2013, 257, (17), 2468-2483.

114. Hwang, Y.-H.; Kim, D.-G.; Shin, H.-S., Effects of synthesis conditions on the characteristics and reactivity of nano scale zero valent iron. Applied Catalysis B: Environmental 2011, 105, (1-2), 144-150.

115. Lu, H.-J.; Wang, J.-K.; Ferguson, S.; Wang, T.; Bao, Y.; Hao, H.-X., Mechanism, synthesis and modification of nano zerovalent iron in water treatment. Nanoscale 2016, 8, (19), 9962-9975.

116. Yuvakkumar, R.; Elango, V.; Rajendran, V.; Kannan, N., Preparation and characterization of zero valent iron nanoparticles. Digest Journal of Nanomaterials and Biostructures 2011, 6, (4), 1771-1776.

117. Fryxell, G. E., Synthesis of nanostructured hybrid sorbent materials using organosilane self-assembly on mesoporous ceramic oxides. Environmental Applications of Nanomaterials: Synthesis, Sorbents and Sensors, ed. GE Fryxell and G. Cao, Imperial College Press, London 2007, 159-178. 
118. Sun, Q.; Feitz, A. J.; Guan, J.; Waite, T. D., Comparison of the reactivity of nanosized zero-valent iron (nZVI) particles produced by borohydride and dithionite reduction of iron salts. Nano 2008, 3, (05), 341-349.

119. Xie, Y.; Cwiertny, D. M., Use of dithionite to extend the reactive lifetime of nanoscale zero-valent iron treatment systems. Environmental science \& technology 2010, 44, (22), 8649-8655.

120. Su, C.; Ludwig, R. D., Treatment of hexavalent chromium in chromite ore processing solid waste using a mixed reductant solution of ferrous sulfate and sodium dithionite. Environmental science \& technology 2005, 39, (16), 6208-6216.

121. Ma, X.; He, D.; Jones, A. M.; Collins, R. N.; Waite, T. D., Reductive reactivity of borohydride-and dithionite-synthesized iron-based nanoparticles: A comparative study. Journal of hazardous materials 2016, 303, 101-110.

122. Feitz, A.; Guan, J.; Waite, D. Process for producing a nanoscale zero-valent metal. 2004.

123. Li, T.; Farrell, J., Reductive dechlorination of trichloroethene and carbon tetrachloride using iron and palladized-iron cathodes. Environmental Science \& Technology 2000, 34, (1), 173-179.

124. Xu, Y.; Zhang, W.-X., Subcolloidal Fe/Ag particles for reductive dehalogenation of chlorinated benzenes. Industrial \& Engineering Chemistry Research 2000, 39, (7), 2238-2244.

125. Li, F.; Vipulanandan, C.; Mohanty, K. K., Microemulsion and solution approaches to nanoparticle iron production for degradation of trichloroethylene. Colloids and Surfaces A: Physicochemical and Engineering Aspects 2003, 223, (1), 103-112.

126. Wang, W.; Zhou, M., Degradation of trichloroethylene using solvent-responsive polymer coated Fe nanoparticles. Colloids and Surfaces A: Physicochemical and Engineering Aspects 2010, 369, (1-3), 232-239.

127. Li, T.; Li, S.; Wang, S.; An, Y.; Jin, Z., Preparation of nanoiron by water-in-oil (W/O) microemulsion for reduction of nitrate in groundwater. Journal of Water Resource and Protection 2009, 1, (1), 16.

128. Jamei, M. R.; Khosravi, M. R.; Anvaripour, B., A novel ultrasound assisted method in synthesis of NZVI particles. Ultrasonics Sonochemistry 2014, 21, (1), 226-233.

129. Tiehm, A.; Kraßnitzer, S.; Koltypin, Y.; Gedanken, A., Chloroethene dehalogenation with ultrasonically produced air-stable nano iron. Ultrasonics Sonochemistry 2009, 16, (5), 617-621.

130. Banerjee, S.; Roy, S.; Chen, J.; Chakravorty, D., Magnetic properties of oxide-coated iron nanoparticles synthesized by electrodeposition. Journal of magnetism and magnetic materials 2000, 219, (1), 45-52.

131. Choi, C.; Tolochko, O.; Kim, B., Preparation of iron nanoparticles by chemical vapor condensation. Materials Letters 2002, 56, (3), 289-294.

132. Park, S.-J.; Kim, S.; Lee, S.; Khim, Z. G.; Char, K.; Hyeon, T., Synthesis and magnetic studies of uniform iron nanorods and nanospheres. Journal of the American Chemical Society 2000, 122, (35), 8581-8582.

133. Horikoshi, S.; Serpone, N., Microwaves in nanoparticle synthesis: fundamentals and applications. John Wiley \& Sons: 2013.

134. Sun, H.; Zhou, G.; Liu, S.; Ang, H. M.; Tadé, M. O.; Wang, S., Nano-Fe0 encapsulated in microcarbon spheres: synthesis, characterization, and environmental applications. ACS applied materials \& interfaces 2012, 4, (11), 6235-6241. 
135. Joseyphus, R. J.; Shinoda, K.; Kodama, D.; Jeyadevan, B., Size controlled Fe nanoparticles through polyol process and their magnetic properties. Materials Chemistry and Physics 2010, 123, (2), 487-493.

136. Anastas, P. T.; Warner, J. C., Principles of green chemistry. Green chemistry: Theory and practice 1998, 29-56.

137. Narayanan, K. B.; Sakthivel, N., Green synthesis of biogenic metal nanoparticles by terrestrial and aquatic phototrophic and heterotrophic eukaryotes and biocompatible agents. Advances in Colloid and Interface Science 2011, 169, (2), 59-79.

138. Saif, S.; Tahir, A.; Chen, Y., Green synthesis of iron nanoparticles and their environmental applications and implications. Nanomaterials 2016, 6, (11), 209.

139. Kaul, R. K.; Kumar, P.; Burman, U.; Joshi, P.; Agrawal, A.; Raliya, R.; Tarafdar, J. C., Magnesium and iron nanoparticles production using microorganisms and various salts. Materials Science-Poland 2012, 30, (3), 254-258.

140. Pavani, K.; Kumar, N. S., Adsorption of iron and synthesis of iron nanoparticles by Aspergillus species Kvp 12. American Journal of Nanomaterials 2013, 1, (2), 24-26.

141. Dhillon, G. S.; Brar, S. K.; Kaur, S.; Verma, M., Green approach for nanoparticle biosynthesis by fungi: current trends and applications. Critical Reviews in Biotechnology 2011, 32, (1), 49-73.

142. Iravani, S., Green synthesis of metal nanoparticles using plants. Green Chemistry 2011, 13, (10), 2638.

143. Guo, Q.; Guo, Q.; Yuan, J.; Zeng, J., Biosynthesis of gold nanoparticles using a kind of flavonol: Dihydromyricetin. Colloids and Surfaces A: Physicochemical and Engineering Aspects 2014, 441, 127-132.

144. Ashokkumar, S.; Ravi, S.; Kathiravan, V.; Velmurugan, S., Retracted: Synthesis, characterization and catalytic activity of silver nanoparticles using Tribulus terrestris leaf extract. Spectrochimica Acta Part A: Molecular and Biomolecular Spectroscopy 2014, 121, 88-93.

145. Bors, W.; Heller, W.; Michael, M., Flavonoids as antioxidants: determination of radical scavenging efficiencies. Edited by CA Rice, E Vans and L Packer. Marcel Dekker, New York: 1998.

146. Shahidi, F.; Janitha, P.; Wanasundara, P., Phenolic antioxidants. Critical reviews in food science \& nutrition 1992, 32, (1), 67-103.

147. Afanas' ev, I. B.; Dcrozhko, A. I.; Brodskii, A. V.; Kostyuk, V. A.; Potapovitch, A. I., Chelating and free radical scavenging mechanisms of inhibitory action of rutin and quercetin in lipid peroxidation. Biochemical pharmacology 1989, 38, (11), 1763-1769.

148. Lugasi, A.; Hóvári, J.; Sági, K. V.; Bíró, L., The role of antioxidant phytonutrients in the prevention of diseases. Acta Biologica Szegediensis 2003, 47, (1-4), 119-25.

149. Mohanpuria, P.; Rana, N. K.; Yadav, S. K., Biosynthesis of nanoparticles: technological concepts and future applications. Journal of Nanoparticle Research 2007, 10, (3), 507517.

150. Hoag, G. E.; Collins, J. B.; Holcomb, J. L.; Hoag, J. R.; Nadagouda, M. N.; Varma, R. S., Degradation of bromothymol blue by 'greener' nano-scale zero-valent iron synthesized using tea polyphenols. Journal of Materials Chemistry 2009, 19, (45), 8671.

151. Huang, L.; Weng, X.; Chen, Z.; Megharaj, M.; Naidu, R., Green synthesis of iron nanoparticles by various tea extracts: Comparative study of the reactivity. Spectrochimica Acta Part A: Molecular and Biomolecular Spectroscopy 2014, 130, 295-301. 
152. Machado, S.; Pinto, S. L.; Grosso, J. P.; Nouws, H. P. A.; Albergaria, J. T.; DelerueMatos, C., Green production of zero-valent iron nanoparticles using tree leaf extracts. Science of The Total Environment 2013, 445-446, 1-8.

153. Gao, J.-F.; Li, H.-Y.; Pan, K.-L.; Si, C.-Y., Green synthesis of nanoscale zero-valent iron using a grape seed extract as a stabilizing agent and the application for quick decolorization of azo and anthraquinone dyes. RSC Adv. 2016, 6, (27), 22526-22537.

154. Machado, S.; Stawiński, W.; Slonina, P.; Pinto, A. R.; Grosso, J. P.; Nouws, H. P. A.; Albergaria, J. T.; Delerue-Matos, C., Application of green zero-valent iron nanoparticles to the remediation of soils contaminated with ibuprofen. Science of The Total Environment 2013, 461-462, 323-329.

155. Phenrat, T.; Saleh, N.; Sirk, K.; Kim, H.-J.; Tilton, R. D.; Lowry, G. V., Stabilization of aqueous nanoscale zerovalent iron dispersions by anionic polyelectrolytes: adsorbed anionic polyelectrolyte layer properties and their effect on aggregation and sedimentation. Journal of Nanoparticle Research 2008, 10, (5), 795-814.

156. Sun, Y.-P.; Li, X.-Q.; Zhang, W.-X.; Wang, H. P., A method for the preparation of stable dispersion of zero-valent iron nanoparticles. Colloids and Surfaces A: Physicochemical and Engineering Aspects 2007, 308, (1), 60-66.

157. Choi, H.-C.; Kanel, S. R. Method of synthesizing zerovalent iron nanowires and application of the same to groundwater treatment. 2007.

158. Cirtiu, C. M.; Raychoudhury, T.; Ghoshal, S.; Moores, A., Systematic comparison of the size, surface characteristics and colloidal stability of zero valent iron nanoparticles pre- and post-grafted with common polymers. Colloids and Surfaces A: Physicochemical and Engineering Aspects 2011, 390, (1-3), 95-104.

159. Zhou, L.; Thanh, T. L.; Gong, J.; Kim, J.-H.; Kim, E.-J.; Chang, Y.-S., Carboxymethyl cellulose coating decreases toxicity and oxidizing capacity of nanoscale zerovalent iron. Chemosphere 2014, 104, 155-161.

160. Dror, I.; Jacov, O. M.; Cortis, A.; Berkowitz, B., Catalytic transformation of persistent contaminants using a new composite material based on nanosized zero-valent iron. ACS applied materials \& interfaces 2012, 4, (7), 3416-3423.

161. Sakulchaicharoen, N.; O'Carroll, D. M.; Herrera, J. E., Enhanced stability and dechlorination activity of pre-synthesis stabilized nanoscale FePd particles. Journal of Contaminant Hydrology 2010, 118, (3-4), 117-127.

162. Ge, L.; Li, Q.; Wang, M.; Ouyang, J.; Li, X.; Xing, M. M., Nanosilver particles in medical applications: synthesis, performance, and toxicity. International journal of nanomedicine 2014, 9, 2399.

163. Ahmed, S.; Ahmad, M.; Swami, B. L.; Ikram, S., A review on plants extract mediated synthesis of silver nanoparticles for antimicrobial applications: A green expertise. Journal of Advanced Research 2016, 7, (1), 17-28.

164. Xing, M.; Ge, L.; Wang, M.; Li, Q.; Li, X.; Ouyang, J., Nanosilver particles in medical applications: synthesis, performance, and toxicity. International Journal of Nanomedicine 2014, 2399.

165. Guzman, M.; Dille, J.; Godet, S., Synthesis and antibacterial activity of silver nanoparticles against gram-positive and gram-negative bacteria. Nanomedicine: Nanotechnology, Biology and Medicine 2012, 8, (1), 37-45.

166. Rai, M. K.; Deshmukh, S. D.; Ingle, A. P.; Gade, A. K., Silver nanoparticles: the powerful nanoweapon against multidrug-resistant bacteria. Journal of Applied Microbiology 2012, 112, (5), 841-852. 
167. Galdiero, S.; Falanga, A.; Vitiello, M.; Cantisani, M.; Marra, V.; Galdiero, M., Silver nanoparticles as potential antiviral agents. Molecules 2011, 16, (12), 8894-8918.

168. Patra, S.; Mukherjee, S.; Barui, A. K.; Ganguly, A.; Sreedhar, B.; Patra, C. R., Green synthesis, characterization of gold and silver nanoparticles and their potential application for cancer therapeutics. Materials Science and Engineering: C 2015, 53, 298-309.

169. Rajawat, S.; Kurchania, R.; Rajukumar, K.; Pitale, S.; Saha, S.; Qureshi, M. S., Study of anti-cancer properties of green silver nanoparticles against MCF-7 breast cancer cell lines. Green Processing and Synthesis 2016, 5, (2).

170. You, C.; Han, C.; Wang, X.; Zheng, Y.; Li, Q.; Hu, X.; Sun, H., The progress of silver nanoparticles in the antibacterial mechanism, clinical application and cytotoxicity. Molecular Biology Reports 2012, 39, (9), 9193-9201.

171. Locatelli, E.; Naddaka, M.; Uboldi, C.; Loudos, G.; Fragogeorgi, E.; Molinari, V.; Pucci, A.; Tsotakos, T.; Psimadas, D.; Ponti, J.; Franchini, M. C., Targeted delivery of silver nanoparticles and alisertib: in vitro and in vivo synergistic effect against glioblastoma. Nanomedicine 2014, 9, (6), 839-849.

172. Ong, C.; Lim, J. Z. Z.; Ng, C. T.; Li, J. J.; Yung, L. Y. L.; Bay, B. H., Silver nanoparticles in cancer: therapeutic efficacy and toxicity. Current Medicinal Chemistry 2013, 20, (6), 772-781.

173. Iravani, S.; Korbekandi, H.; Mirmohammadi, S.; Zolfaghari, B., Synthesis of silver nanoparticles: chemical, physical and biological methods. Research in pharmaceutical sciences 2014, 9, (6), 385.

174. Janardhanan, R.; Karuppaiah, M.; Hebalkar, N.; Rao, T. N., Synthesis and surface chemistry of nano silver particles. Polyhedron 2009, 28, (12), 2522-2530.

175. Sharma, V. K.; Yngard, R. A.; Lin, Y., Silver nanoparticles: green synthesis and their antimicrobial activities. Advances in colloid and interface science 2009, 145, (1), 83-96.

176. Hebbalalu, D.; Lalley, J.; Nadagouda, M. N.; Varma, R. S., Greener techniques for the synthesis of silver nanoparticles using plant extracts, enzymes, bacteria, biodegradable polymers and microwaves. ACS Sustainable Chemistry \& Engineering 2013, 1, (7), 703-712.

177. Mittal, A. K.; Chisti, Y.; Banerjee, U. C., Synthesis of metallic nanoparticles using plant extracts. Biotechnology Advances 2013, 31, (2), 346-356.

178. Shankar, S. S.; Ahmad, A.; Sastry, M., Geranium leaf assisted biosynthesis of silver nanoparticles. Biotechnology Progress 2003, 19, (6), 1627-1631.

179. Shankar, S. S.; Rai, A.; Ahmad, A.; Sastry, M., Rapid synthesis of Au, Ag, and bimetallic Au core-Ag shell nanoparticles using Neem (Azadirachta indica) leaf broth. Journal of Colloid and Interface Science 2004, 275, (2), 496-502.

180. Song, J. Y.; Kim, B. S., Rapid biological synthesis of silver nanoparticles using plant leaf extracts. Bioprocess and Biosystems Engineering 2008, 32, (1), 79-84.

181. Dhand, V.; Soumya, L.; Bharadwaj, S.; Chakra, S.; Bhatt, D.; Sreedhar, B., Green synthesis of silver nanoparticles using Coffea arabica seed extract and its antibacterial activity. Materials Science and Engineering: C 2016, 58, 36-43.

182. Baharara, J.; Namvar, F.; Ramezani, T.; Mousavi, M.; Mohamad, R., Silver nanoparticles biosynthesized using Achillea biebersteinii flower extract: apoptosis induction in MCF-7 cells via caspase activation and regulation of Bax and Bcl-2 gene expression. Molecules 2015, 20, (2), 2693-2706. 
183. Ajitha, B.; Reddy, Y. A. K.; Reddy, P. S., Green synthesis and characterization of silver nanoparticles using Lantana camara leaf extract. Materials Science and Engineering: $C$ 2015, 49, 373-381.

184. Nadagouda, M. N.; Varma, R. S., Green synthesis of silver and palladium nanoparticles at room temperature using coffee and tea extract. Green Chemistry 2008, 10, (8), 859.

185. Begum, N. A.; Mondal, S.; Basu, S.; Laskar, R. A.; Mandal, D., Biogenic synthesis of $\mathrm{Au}$ and $\mathrm{Ag}$ nanoparticles using aqueous solutions of Black Tea leaf extracts. Colloids and surfaces B: Biointerfaces 2009, 71, (1), 113-118.

186. Loo, Y. Y.; Chieng, B. W.; Nishibuchi, M.; Radu, S., Synthesis of silver nanoparticles by using tea leaf extract from Camellia sinensis. International journal of nanomedicine 2012, 7, 4263.

187. Chandran, S. P.; Chaudhary, M.; Pasricha, R.; Ahmad, A.; Sastry, M., Synthesis of gold nanotriangles and silver nanoparticles using Aloe vera plant extract. Biotechnology Progress 2006, 22, (2), 577-583.

188. Gröning, R.; Breitkreutz, J.; Baroth, V.; Müller, R., Nanoparticles in plant extracts-factors which influence the formation of nanoparticles in black tea infusions. Die Pharmazie 2001, 56, (10), 790-792.

189. Moulton, M. C.; Braydich-Stolle, L. K.; Nadagouda, M. N.; Kunzelman, S.; Hussain, S. M.; Varma, R. S., Synthesis, characterization and biocompatibility of "green" synthesized silver nanoparticles using tea polyphenols. Nanoscale 2010, 2, (5), 763.

190. Sun, Q.; Cai, X.; Li, J.; Zheng, M.; Chen, Z.; Yu, C.-P., Green synthesis of silver nanoparticles using tea leaf extract and evaluation of their stability and antibacterial activity. Colloids and Surfaces A: Physicochemical and Engineering Aspects 2014, 444, 226-231.

191. Rasband, W., ImageJ. Bethesda, MD: US National Institutes of Health. ht tp://rsb. info. nih. gov/ij 1997, 1997-2007.

192. Zetasizer Nano User Manual, M. I. L.

193. Löffler, F. E.; Tiedje, J. M.; Sanford, R. A., Fraction of electrons consumed in electron acceptor reduction and hydrogen thresholds as indicators of halorespiratory physiology. Applied and Environmental Microbiology 1999, 65, (9), 4049-4056.

194. Rosner, B. M.; McCarty, P. L.; Spormann, A. M., In vitro studies on reductive vinyl chloride dehalogenation by an anaerobic mixed culture. Applied and environmental microbiology 1997, 63, (11), 4139-4144.

195. Suzuki, M. T.; Giovannoni, S. J., Bias caused by template annealing in the amplification of mixtures of $16 \mathrm{~S}$ rRNA genes by PCR. Applied and environmental microbiology 1996, 62, (2), 625-630.

196. Muyzer, G.; De Waal, E. C.; Uitterlinden, A. G., Profiling of complex microbial populations by denaturing gradient gel electrophoresis analysis of polymerase chain reaction-amplified genes coding for $16 \mathrm{~S}$ rRNA. Applied and environmental microbiology 1993, 59, (3), 695-700.

197. TotalLab honlapja, http://totallab.com/cliqs-1d-pro/.

198. Corless, C. E.; Guiver, M.; Borrow, R.; Edwards-Jones, V.; Kaczmarski, E. B.; Fox, A. J., Contamination and sensitivity issues with a real-time universal 16S rRNA PCR. Journal of clinical microbiology 2000, 38, (5), 1747-1752.

199. Steinberg, L. M.; Regan, J. M., Phylogenetic comparison of the methanogenic communities from an acidic, oligotrophic fen and an anaerobic digester treating 
municipal wastewater sludge. Applied and environmental microbiology 2008, 74, (21), 6663-6671.

200. Ben-Dov, E.; Brenner, A.; Kushmaro, A., Quantification of sulfate-reducing bacteria in industrial wastewater, by real-time polymerase chain reaction (PCR) using dsrA and apsA genes. Microbial ecology 2007, 54, (3), 439-451.

201. Ritalahti, K. M.; Amos, B. K.; Sung, Y.; Wu, Q.; Koenigsberg, S. S.; Löffler, F. E., Quantitative PCR targeting 16S rRNA and reductive dehalogenase genes simultaneously monitors multiple Dehalococcoides strains. Applied and Environmental Microbiology 2006, 72, (4), 2765-2774.

202. Livak, K. J.; Schmittgen, T. D., Analysis of relative gene expression data using realtime quantitative PCR and the 2- $\Delta \Delta C$ T method. methods 2001, 25, (4), 402-408.

203. 201/2001. (X. 25.) Korm. rendelet az ivóvíz minőségi követelményeiről és az ellenőrzés rendjéröl, http://net.jogtar.hu.

204. Kumar, K. M.; Mandal, B. K.; Kumar, K. S.; Reddy, P. S.; Sreedhar, B., Biobased green method to synthesise palladium and iron nanoparticles using Terminalia chebula aqueous extract. Spectrochimica Acta Part A: Molecular and Biomolecular Spectroscopy 2013, 102, 128-133.

205. Morikawa, C. K.; Shinohara, M., Heterogeneous photodegradation of methylene blue with iron and tea or coffee polyphenols in aqueous solutions. Water Science and Technology 2016, 73, (8), 1872-1881.

206. Kim, H. J.; Saleem, M.; Seo, S. H.; Jin, C.; Lee, Y. S., Two new antioxidant stilbene dimers, parthenostilbenins $\mathrm{A}$ and $\mathrm{B}$ from Parthenocissus tricuspidata. Planta medica 2005, 71, (10), 973-976.

207. Kerkez, D. V.; Tomašević, D. D.; Kozma, G.; Bečelić-Tomin, M. R.; Prica, M. D.; Rončević, S. D.; Kukovecz, Á.; Dalmacija, B. D.; Kónya, Z., Three different claysupported nanoscale zero-valent iron materials for industrial azo dye degradation: a comparative study. Journal of the Taiwan Institute of Chemical Engineers 2014, 45, (5), 2451-2461.

208. Sun, Y.-P.; Li, X.-q.; Cao, J.; Zhang, W.-X.; Wang, H. P., Characterization of zerovalent iron nanoparticles. Advances in colloid and interface science 2006, 120, (1), 4756.

209. Kozma, G.; Rónavári, A.; Kónya, Z.; Kukovecz, Á., Environmentally benign synthesis methods of zero-valent iron nanoparticles. ACS Sustainable Chemistry \& Engineering 2016, 4, (1), 291-297.

210. Sun, Y.; Xia, Y., Shape-controlled synthesis of gold and silver nanoparticles. Science 2002, 298, (5601), 2176-2179.

211. Xia, Y.; Xiong, Y.; Lim, B.; Skrabalak, S. E., Shape controlled synthesis of metal nanocrystals: simple chemistry meets complex physics? Angewandte Chemie International Edition 2009, 48, (1), 60-103.

212. O’Carroll, D.; Sleep, B.; Krol, M.; Boparai, H.; Kocur, C., Nanoscale zero valent iron and bimetallic particles for contaminated site remediation. Advances in Water Resources 2013, 51, 104-122.

213. Kocur, C. M.; Chowdhury, A. I.; Sakulchaicharoen, N.; Boparai, H. K.; Weber, K. P.; Sharma, P.; Krol, M. M.; Austrins, L.; Peace, C.; Sleep, B. E., Characterization of nZVI mobility in a field scale test. Environmental science \& technology 2014, 48, (5), 28622869. 
214. Quinn, J.; Geiger, C.; Clausen, C.; Brooks, K.; Coon, C.; O'Hara, S.; Krug, T.; Major, D.; Yoon, W.-S.; Gavaskar, A., Field demonstration of DNAPL dehalogenation using emulsified zero-valent iron. Environmental Science \& Technology 2005, 39, (5), 13091318.

215. Su, C.; Puls, R. W.; Krug, T. A.; Watling, M. T.; O'Hara, S. K.; Quinn, J. W.; Ruiz, N. E., A two and half-year-performance evaluation of a field test on treatment of source zone tetrachloroethene and its chlorinated daughter products using emulsified zero valent iron nanoparticles. Water research 2012, 46, (16), 5071-5084.

216. Wei, Y.-T.; Wu, S.-C.; Chou, C.-M.; Che, C.-H.; Tsai, S.-M.; Lien, H.-L., Influence of nanoscale zero-valent iron on geochemical properties of groundwater and vinyl chloride degradation: a field case study. water research 2010, 44, (1), 131-140.

217. Wei, Y.-T.; Wu, S.-c.; Yang, S.-W.; Che, C.-H.; Lien, H.-L.; Huang, D.-H., Biodegradable surfactant stabilized nanoscale zero-valent iron for in situ treatment of vinyl chloride and 1, 2-dichloroethane. Journal of hazardous materials 2012, 211, 373380.

218. Zabetakis, K. M.; Niño de Guzmán, G. T.; Torrents, A.; Yarwood, S., Toxicity of zerovalent iron nanoparticles to a trichloroethylene-degrading groundwater microbial community. Journal of Environmental Science and Health, Part A 2015, 50, (8), 794805.

219. Hantke, K., Iron and metal regulation in bacteria. Current opinion in microbiology 2001, 4, (2), 172-177.

220. Kocur, C. M. D.; Edwards, E. A.; O’Carroll, D. M., Long-term field study of microbial community and dechlorinating activity following carboxymethyl cellulose-atabilized nanoscale zero-valent iron injection. Environmental Science \& Technology 2016, 50, (14), 7658-7670.

221. Nel, A. E.; Mädler, L.; Velegol, D.; Xia, T.; Hoek, E. M.; Somasundaran, P.; Klaessig, F.; Castranova, V.; Thompson, M., Understanding biophysicochemical interactions at the nano-bio interface. Nature materials 2009, 8, (7), 543-557. 